\title{
Grilhões invisíveis
}

as dimensões da ideologia, as condições de subalternidade e a educação em Gramsci

\author{
Anita Helena Schlesener
}

\section{SciELO Books / SciELO Livros / SciELO Libros}

SCHLESENER, AH. Grilhões invisíveis: as dimensões da ideologia, as condições de subalternidade e a educação em Gramsci [online]. Ponta Grossa: Editora UEPG, 2016, 195 p. ISBN 978-85-7798-2349. Available from: doi: 10.7476/9788577982349. Also available in ePUB from: http://books.scielo.org/id/y3zhj/epub/Schlesener-9788577982349.epub.

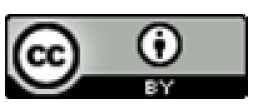

All the contents of this work, except where otherwise noted, is licensed under a Creative Commons Attribution $\underline{4.0 \text { International license. }}$

Todo o conteúdo deste trabalho, exceto quando houver ressalva, é publicado sob a licença Creative Commons Atribição 4.0.

Todo el contenido de esta obra, excepto donde se indique lo contrario, está bajo licencia de la licencia Creative Commons Reconocimento 4.0 . 


\section{Grilhões Invisíveis}

As dimensões da ideologia, as condições de subalternidade e a educação em Gramsci 


\title{
UNIVERSIDADE ESTADUAL DE PONTA GROSSA
}

\author{
REITOR EDITORA UEPG \\ Carlos Luciano Sant'Ana Vargas Lucia Cortes da Costa \\ VICE-REITORA CONSELHO EDITORIAL \\ Gisele Alves de Sá Quimelli Lucia Cortes da Costa (Presidente) \\ Augusta Pelinski Raiher \\ PRÓ-REITORA DE EXTENSÃO Bruno Pedroso \\ E ASSUNTOS CULTURAIS Dircéia Moreira \\ Marilisa do Rocio Oliveira Ivo Mottin Demiate \\ Jefferson Mainardes \\ Jussara Ayres Bourguignon \\ Marilisa do Rocio Oliveira \\ Silvio Luiz Rutz da Silva
}




\section{ANITA HELENA}

SCHLESENER

\section{Grilhões Invisíveis}

As dimensões da ideologia, as condições de subalternidade e a educação em Gramsci

\section{Editora UEPG}




\title{
Copyright $(\subset$ by Anita Helena Schlesener \& Editora UEPG
}

Nenhuma parte deste livro, sem autorização prévia por escrito da Editora, poderá ser reproduzida ou transmitida, sejam quais forem os meios empregados: eletrônicos, mecânicos, fotográficos, gravação ou quaisquer outros.

\author{
Equipe Editorial \\ Coordenação editorial Lucia Cortes da Costa \\ Revisão ICQ Editora Gráfica \\ Capa Leonardo Schlesener \\ Diagramação e Projeto gráfico Marco Wrobel
}

Ficha Catalográfica elaborada pelo Setor de Tratamento da Informação BICEN/UEPG

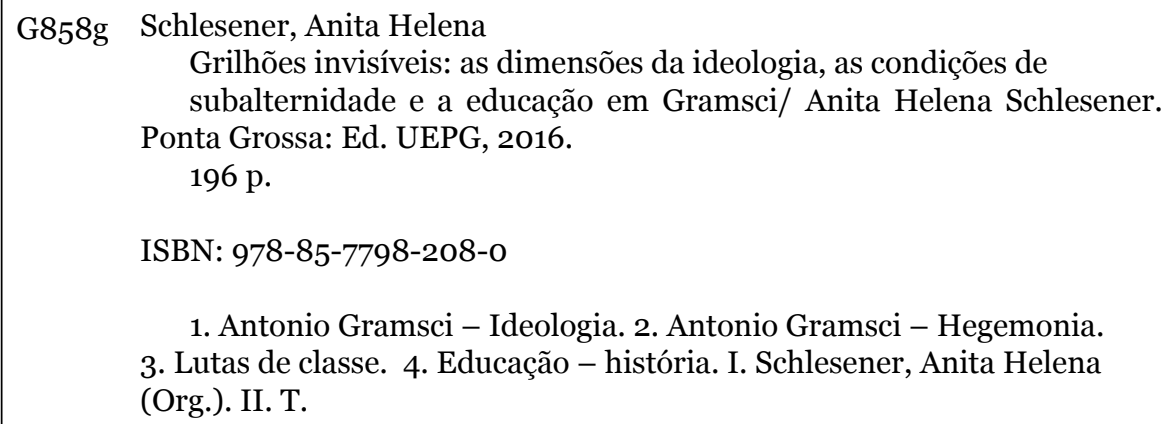

Grilhões invisíveis: as dimensões da ideologia, as condições de subalternidade e a educação em Gramsci/ Anita Helena Schlesener. Ponta Grossa: Ed. UEPG, 2016.

$196 \mathrm{p}$.

ISBN: 978-85-7798-208-O

1. Antonio Gramsci - Ideologia. 2. Antonio Gramsci - Hegemonia. 3. Lutas de classe. 4. Educação - história. I. Schlesener, Anita Helena (Org.). II. T.

CDD: 370.92

\section{Depósito legal na Biblioteca Nacional}

\section{Editora filiada à ABEU \\ Associação Brasileira das Editoras Universitárias}

\author{
Editora UEPG \\ Praça Santos Andrade, n. 1 \\ 84030-900 - Ponta Grossa - Paraná \\ Fone: (42) 3220-3306 \\ e-mail: vendas.editora@uepg.br
}




\section{Prefácio}

Este livro de Anita Helena Schlesener mostra uma pesquisadora em plena maturidade da sua reflexão teórica. Anita tem livros importantes sobre Gramsci de Turim, textos que já nos fazem perceber como o pensamento de Gramsci agia com força no debate ideológico, na crítica radical da ordem social vigente na Itália e na Europa. Por sua vez, o livro que o leitor agora manuseia discute um tema crucial dentro do campo teórico/prático da tradição inaugurada por Karl Marx, a educação, mas traz a contribuição e mediação de Gramsci para pensar elementos de construção da hegemonia burguesa, como a linguagem e a própria educação. Mas a finalidade mesmo é abordar o tema difícil, mas essencial, de uma educação emancipatória para o mundo atual, um mundo inteiramente dominado pelo capital e que expõe sem qualquer pudor a sua horrível face da regressão cultural e da barbárie tecnológica e que mesmo assim mantem também o domínio ideológico.

Sabe-se que a educação é parte essencial da reprodução social e, por decorrência, é momento nodal para que se fechem os grilhões que definem a ordem social e que fazem com que essa ordem social pareça natural. São grilhões invisíveis, mas pesados, pois impossível dissociar a reprodução da vida material e a reprodução da consciência. O peso invisível e aparentemente natural e indiscutível encontra-se na dimensão da ideologia, que convence que a reprodução social da vida material é aquela que se apresenta e nenhuma outra.

Assim, a análise de Marx perfaz essencialmente a ideologia dominante, aquela que se exterioriza das relações sociais de produção, que garante o poder político de classe ao mesmo tempo em que submete as classes subordinadas. Nesse sentido, então, a ideologia só pode ter uma conotação negativa e que Marx via ser elaborada em institutos particulares como Igreja, escola, livros e jornais. Era expressão de uma falsa consciência somente porque ideologia que organiza a vida material que se funda na exploração do trabalho, no trabalho que se exterioriza e que se aliena num produto que não é do trabalhador nem da coletividade, que não é expressão de sua vitalidade. $\mathrm{O}$ trabalhador, assim alienado, não é capaz de erigir uma ideologia articulada e complexa, que seja científica. A ciência, em primeira instância é ideologia burguesa, pois se desenvolve segundo a visão ideológica do mundo e das necessidades materiais da sociedade burguesa. 
Tempos depois, logo após a morte de Marx (1883), seu amigo e colaborador Engels acabou por fazer do marxismo a ideologia do movimento operário, uma concepção de ciência originada a partir da perspectiva do trabalho e da emancipação humana, mas usando uma linguagem diferenciada e própria. É assim que a noção de ideologia pode ganhar a sua conotação positiva e como tal foi fartamente utilizada por Lenin. Pode-se então observar que as duas perspectivas científicas e ideológicas são parte da luta de classes. Não que sejam duas "ciências" diferentes, como alguém poderia imaginar, mas a ciência é um produto social que avança por uma ou outra direção de acordo com as necessidades de produção da vida material e espiritual, de acordo com a correlação de forças na vida social.

Decerto que a ciência é apenas uma parte que pode organizar uma visão de mundo, pois que na ordem burguesa a sobrevivência da religião é indispensável para garantir a posição de subordinação de largas faixas das camadas populares, mas mesmo entre os intelectuais orgânicos da ordem dominante a religião sobrevive em formas variadas, desde sofisticadas concepções filosóficas até em religiões institucionalizadas. Mas o marxismo ou, melhor dizendo, a Filosofia da práxis, ao redefinir a sociabilidade do homem, que socialmente passa a ver o outro homem como ser genérico - igualmente livre e sujeito da sua própria liberdade - não pode observar os complexos ideológicos da ciência e da religião da época burguesa senão como óbices para a emancipação humana. Pode parecer estranha tal afirmativa, mas tem sido instrumentos de construção e preservação da ordem, ainda que a objetividade da ciência, por suposto, seja inegável.

Ao retomar de Marx a categoria de Filosofia da práxis como expressão teórico/prática do complexo ideológico da época burguesa, Gramsci elabora categorias correlatas como as de bloco histórico e hegemonia. $\mathrm{O}$ bloco histórico e a hegemonia burguesa tiveram o seu fundamento material deslindado por Marx ao captar o movimento contraditório do capital. Soube ele, desde logo, que o invólucro ideológico era essencial a esse movimento, pois era imprescindível que se cresse que no mercado haveria uma troca de valores iguais, que no Estado estivesse representado o interesse público. Ademais, Marx, ao definir a práxis como chave da emancipação humana, indicava que na luta de classes se travava a disputa pela criação de uma nova sociabilidade, de uma forma inteiramente nova do homem social se relacionar com o mundo natural e se portar como espécie.

Em Gramsci observa-se um avanço significativo na reflexão teórica precisamente pela percepção da importância da noção de filosofia da práxis, 
pela possibilidade de ser essa uma via para sugerir a importância da subjetividade, da vontade, na apreensão da realidade. Penso serem descabidas as suposições de um Gramsci filosoficamente idealista. Para Gramsci, a realidade do mundo só se demonstra na práxis, quando o conhecimento humano se apropria da materialidade do mundo, que obviamente precede a existência da consciência própria do homem. De modo algum isso pode significar que a realidade material do mundo depende da existência do homem.

Mas que relação pode isso tudo ter com a questão do domínio de classe e da ideologia? Em Gramsci, como antes dito, as categorias de bloco histórico e de hegemonia transcendem a noção de ideologia como antes posta por Marx e, de forma diferente, por Lenin. O bloco histórico constituído pelo movimento do capital no momento em que esse se apropria da produção e do conhecimento científico configura a hegemonia de classe da burguesia, a sua visão do mundo dos homens e das coisas. Essa visão se materializa em instituições sociais e políticas, em práticas e costumes, em modos de vida, em valores, em determinada ética, na linguagem e no Direito, que tende a se reproduzir com intensificação e extensão. Essa reprodução social que segue a reprodução ampliada do capital precisa de trabalhadores com perfil determinado pelo maquinário e de massa crescente de intelectuais orgânicos, a qual se diversifica de acordo com a necessidade da produção, mas também com as necessidades sempre mais complexas postas nas supraestruturas da sociedade civil. Essas são condições para que se consolide o bloco histórico da época burguesa e a hegemonia que lhe corresponde.

A reflexão de Gramsci nos Cadernos é sucedânea da derrota da revolução socialista internacional (1917-1921). Essa situação exigiu um direcionamento da filosofia da práxis diferente daqueles postos para Marx e Lenin (também Rosa Luxemburg). Não que Gramsci seja um pensador inteiramente novo, o que seria um completo absurdo, apenas que pensa na trilha aberta por outros em situação, essa sim nova, a qual lhe permite um salto de qualidade significativo.

A formação universitária de Gramsci em Linguística lhe possibilitou mais que outros se enveredar para a crítica da linguagem como ideologia, como forma específica de dominação de classe, como peça essencial da hegemonia. Assim a linguagem implica uma concepção de mundo, implica um conjunto simbólico. Mas a linguagem é essencialmente filosofia, história, política e economia, visto ser expressão de hegemonia que se manifesta no bloco histórico. Nota-se então a importância da abordagem, nesses termos, da linguagem como ideologia que se expressa na ciência e na educação. 
Se a realidade efetiva assim se manifesta, tudo fica mais claro no enorme desafio que tem pela frente a processualidade que venha se direcionar para a emancipação do trabalho humano. Será preciso uma massa de intelectuais organicamente vinculados aos interesses históricos do mundo do trabalho, postados de modo antagônico ao mundo criado pela burguesia. Uma nova hegemonia exige a construção de uma nova linguagem cientifica, uma nova forma de se relacionar com o mundo externo, um novo conjunto de símbolos. De forma de dominação que é no mundo burguês, a ciência e a educação devem vir a ser formas de emancipação, de subversão da práxis.

O problema é que a hegemonia no bloco histórico que é a época burguesa, até por ser um movimento fundado na essência contraditória do capital, não pode exprimir uma filosofia, uma visão de mundo homogênea. Há o convívio, também esse contraditório, de concepções de mundo, desde aquela articulada e sistemática formulada pela intelectualidade da ordem, até outras fragmentárias e fragmentadas incorporadas pelos próprios dominantes, em termos de senso comum, e ainda aquelas difusas entre as classes subalternas. Nesse contexto é que se planta o ambiente material e cultural a partir do qual a nova hegemonia pode ser organizada.

O objetivo da reforma moral e intelectual, pressuposto da nova hegemonia, deve partir mais uma vez da verdade efetiva das coisas, quer dizer, da consciência e cultura dos subalternos. Em meio a essa não existe apenas passividade e submissão, há também contestação e rebeldia. É a partir desse viés que deve se desenvolver a organização e a consciência antagônica dos subalternos no caminho de uma nova hegemonia. A contestação e a rebeldia deve se educar e ser educada numa ação cultural/política persistente, que passará decerto por uma fase econômico-corporativa, mas que não é capaz ainda de conceber a hegemonia e o universo das supraestruturas complexas que a compõe. Esse processo se confunde com a elaboração de uma massa de intelectuais que emergem da própria classe que se constrói e por isso mesmo intelectuais orgânicos, no dizer de Gramsci. Claro que os grupos subalternos, no processo de se fazer classe e logo partido, ficam mais fortes e mais capazes de atraírem intelectuais originados em outros grupos sociais.

O Príncipe Moderno é assim o produto mais elevado de um processo longo por meio do qual o povo trabalhador se faz classe e se faz partido. Esse processo exige que em primeiro plano seja posta a questão da educação e da autoeducação, da organização e da auto-organização, da construção de um projeto coletivo de emancipação e de liberdade. Nesse processo também é que podem ser rompidos os grilhões invisíveis que mantêm a ordem burguesa 
ainda viva e sempre mais agressiva e cruel na sua indispensável relação com os que trabalham e que socialmente produzem a riqueza material.

Basta por agora reafirmar a importante contribuição que esse livro de Anita Helena Schlesener oferece para essas preocupações sugeridas por Marx e por Gramsci. Devemos nunca esquecer, no entanto, que esse é um trabalho árduo e coletivo, mas que uma leitura atenta deste livro e de muitos outros é já de muita utilidade sempre que o conhecimento seja repassado a outros. Ao leitor, então, boa leitura, bom trabalho.

\section{Marcos Del Roio}

Unesp-FFC 


\section{SUMÁRIO}

INTRODUÇÃO

CAPítulo 1 - Às MARgenS dA história: hegemonia e LUTA de CLASSES .... 23

A hegemonia e suas condições históricas: a crítica gramsciana

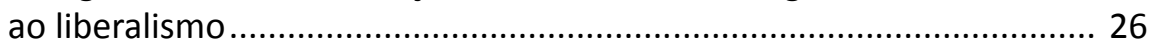

A função dos intelectuais na construção/manutenção da hegemonia ....41 A hegemonia e a luta de classes: a possibilidade de violência

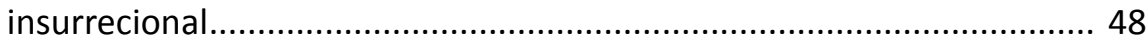

Subversão da praxis x revolução passiva: a atualidade de Gramsci ........ 55

\section{CAPÍTUlo 2 - As DimENSÕes dA IDEOLOGIA A PARTIR DA LEITURA}

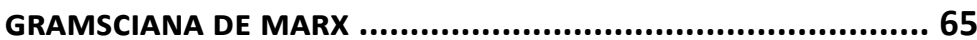

Notas sobre ideologia a partir de A Ideologia Alemã ............................ 70

A noção gramsciana de ideologia ....................................................... 74

A ideologia e a formação da subjetividade .......................................... 84

Elevar as massas ao maior nível intelectual:

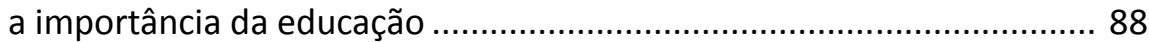

CApítulo 3 - A linguagem em Seu contexto histórico e político ......... 93

Breves observações sobre a questão da linguagem em Marx ................ 96

"Esta mesa redonda é quadrada": a questão da gramática .................. 100

A dimensão simbólica no contexto das lutas de classes ....................... 109

A linguagem como metáfora e a afirmação da identidade

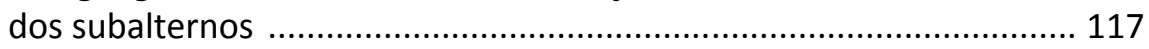

Linguagem, concepção de mundo: a formação dos subalternos ......... 122 
CAPÍTULO 4 - As NOVAS CONDIções DE SUBALTERNIDADE

Explicitações filológicas quanto ao conceito subalternidade ............... 137

A filosofia da praxis como a teoria dos grupos subalternos ................... 143

A ampliação do uso do conceito de "subalterno" por tendências

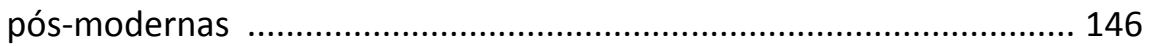

\section{CAPÍTULO 5 - A EduCAÇÃo No CONTEXTO dA HEGEMONIA,} DA IDEOLOGIA E DA LINGUAGEM

A estrutura parlamentar na democracia burguesa e as políticas

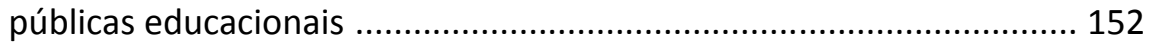

As formas de domínio que se efetivam pela educação ......................... 158

A noção gramsciana de ideologia e o discurso conservador ................. 163

A educação como forma de emancipação para os trabalhadores ........ 168

A educação escolar e a linguagem .................................................. 172

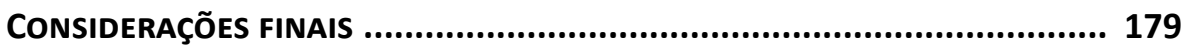

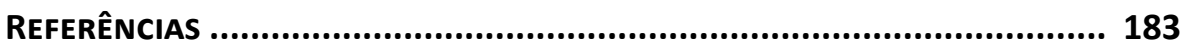




\section{INTRODUÇÃo}

Falar de educação a partir do pensamento de Antonio Gramsci implica, necessariamente, iniciar por sua teoria política, sem a qual a educação perde o seu significado. Como já acentuamos em ocasiões anteriores ${ }^{1}$, Gramsci não foi um pedagogo, mas sim um político militante, líder revolucionário cuja atuação marcou a vida política italiana das primeiras décadas do século $\mathrm{XX}$. Dessa perspectiva, seu pensamento é profundamente contextualizado, embora intensamente atual, porque os problemas que aborda e sobre os quais reflete são ainda problemas do nosso tempo, agora redimensionados. Gramsci não foi um liberal e não pode ser lido nem instrumentalizado nessa perspectiva; foi um revolucionário que contribuiu para explicitar, entre outros fatores, a dimensão ideológica da política para ampliar as possibilidades revolucionárias das classes subalternas e é neste sentido que podemos falar de sua atualidade.

Este trabalho apresenta-se como o resultado de pesquisas sobre a questão da hegemonia nos escritos de Antonio Gramsci a fim de explicitar o sentido da educação em geral e a importância da educação escolar na formação dos trabalhadores. Apresenta-se como o resultado de um projeto de pós-doutorado realizado na Faculdade de Educação da Universidade Estadual de Campinas (Unicamp). Concentra-se em especial nos Cadernos do Cárcere, selecionando, da ampla produção de Gramsci realizada em confinamento, os escritos que permitem explicitar os conceitos de hegemonia, ideologia e linguagem, que consideramos essenciais para o tema da educação.

A educação é um processo que envolve a vida do sujeito desde o nascimento até a morte, ou seja, educamo-nos no movimento histórico, a partir das circunstâncias econômicas, sociais e ideológicas que caracterizam esse movimento. Na sociedade capitalista, a educação, em geral, é entendida como educação formal e escolar, ou seja, um meio pelo qual o indivíduo adapta-se às necessidades e exigências do modo de produção e é formado para desempenhar funções na hierarquia que separa dirigentes de dirigidos. Essa definição permite explicitar as dimensões da ideologia como forma de sustentar o que se apresenta como relações de domínio mascaradas em

1 Referimo-nos a pesquisas que realizamos desde 1980 e que se apresentam em publicações em livros, capítulos de livros e artigos em periódicos publicados ao longo desses 36 anos. Posicionamo-nos criticamente a uma leitura liberal de Gramsci, que prevalece no Brasil e que, a partir de nossa leitura do autor, entendemos equivocada. Da mesma forma, embora tenhamos abordado a questão cultural, nossa posição se explicita contra um culturalismo pós-moderno a partir da constatação gramsciana de que tudo é política e história. 
consenso passivo, em conformismo ou em relações de subalternidade ${ }^{2}$. Trata-se de refletir sobre o fato de que a educação, no contexto de uma sociedade submetida à lógica de produção do capital, vive em seu âmago uma grande contradição: por um lado, preparar para a vida nessa sociedade voltada para a acumulação do capital e inserção no mercado de trabalho; por outro, criar as condições de emancipação política e cultural das classes trabalhadoras por meio da superação dos limites da alienação vigente, a fim de que tenham as condições de lutar por uma nova ordem social.

A pergunta que se colocava na época de Gramsci e que continua a nos interrogar é se a escola pode tornar-se um espaço importante para a formação dos trabalhadores, a fim de assegurar o desenvolvimento integral de sua personalidade individual no contexto de construção de novas relações de formação coletiva. Essa questão implica considerar o contraditório como parte da vida social e ter no horizonte um projeto alternativo de sociedade, visto que na estrutura social vigente se torna muito difícil pensar e agir em termos de formação para o envolvimento coletivo.

A questão central é compreender as dimensões da ideologia com a implementação de novos mecanismos de sustentação da hegemonia e da dominação capitalista com as novas tecnologias de comunicação de massa. Apreender a dimensão histórica das novas estratégias de dominação que se efetivam no processo cultural e comunicativo a partir da inserção de novas tecnologias de comunicação que alteram o processo cognitivo e sensitivo que minam as condições de formação de um pensamento autônomo e, consequentemente, de criação de experiências coletivas.

Os conceitos de hegemonia, ideologia e linguagem se apresentam como pressupostos, porque, a partir da definição de educação acima esboçada, todo o conhecimento tem uma conotação política e, no contexto da modernidade, serve de instrumento para consolidar e manter relações de poder. A noção de hegemonia traz implícito o conceito de ideologia que, no contexto de ampliação dos meios de comunicação de massa, a partir das novas tecnologias, aumentam as possibilidades de dominação por meio da formação do consenso unificado e, consequentemente, as condições de subalternidade.

2 O conceito "subalterno", em Gramsci, amplia em muito a noção de classe social. Apenas para sinalizar, salientamos no item 'A' a dimensão simbólica e a luta de classes (capítulo III) em que subalterno é o indivíduo dominado, mesmo sem ter consciência disso porque vive em um contexto de extrema alienação. Gramsci utiliza as noções "classes subalternas" e "grupos subalternos", noções que adotamos aqui e que serão explicitadas no capítulo IV, dedicado inteiramente a refletir sobre esses conceitos e seus desdobramentos na política e na educação. 
Nesse contexto de leitura, a crítica da linguagem e de seus efeitos políticos se apresenta como um dos momentos de elaboração do conceito de hegemonia enquanto forma de dominação que se sustenta na direção intelectual e moral, ou seja, na constituição e manutenção de uma elite de intelectuais capaz de elaborar um consenso ou de alimentar o senso comum com fragmentos de culturas mesclados com informações pretensamente neutras a fim de incentivar a aceitação do dado, a naturalização da história, a passividade ante o estabelecido, contribuindo para a estabilidade da prática social.

As reflexões apresentadas nos Cadernos do Cárcere retomam algumas ideias produzidas ao longo da militância política de Gramsci e as análises das situações estruturais do capitalismo retomam e ampliam reflexões desenvolvidas em 1926, principalmente em A Questão Meridional. Na noção de hegemonia desdobra-se a análise das características dos países de capitalismo avançado, nos quais a classe dominante possui reservas políticas e organizativas que lhe permitem controlar as crises econômicas e conservar-se no poder. Tais reservas se expressam no fato que o aparato estatal serve de mediador no controle das crises e consegue organizar as forças políticas em presença. Nos Cadernos do Cárcere, Gramsci esclarece que essa característica se deve à importância que assume a cultura na medida em que as relações políticas se constroem fundadas na ideologia ${ }^{3}$. Na sociedade capitalista as relações de poder se constroem como dominação econômica que se sustenta e se consolida pela direção intelectual e moral a partir da formação do homem e de sua conformação aos interesses do trabalho. A hegemonia se funda na formação de um modo de pensar e num processo cultural ao longo do qual a classe social no poder consegue a adesão política de grandes parcelas da sociedade.

A direção intelectual e moral apresenta-se como uma das principais condições tanto para a conquista quanto para o exercício do poder,

3 A ideologia tem um caráter de eficácia histórica e política. Já em 1918 Gramsci explicita o conceito de ideologia, acentuando que Marx "é um ideólogo enquanto homem político atual, enquanto revolucionário" e, como tal, "ou seja, homem atual de ação, não pode prescindir das ideologias e dos esquemas práticos, que são entidades históricas potenciais, em formação" (GRAMSCI, NM, 1984, p. 17). No Caderno 4, encontramos uma definição de ideologia referente ao marxismo. Rebatendo a argumentação de Croce, Gramsci afirma: "Para Marx, as ideologias são tudo menos ilusões e aparência; são uma realidade objetiva e operante". [...] Como Marx poderia ter pensado que as superestruturas são aparência e ilusão? Também as suas doutrinas são uma superestrutura. Marx afirma explicitamente que os homens tomam consciência de suas tarefas no terreno ideológico, das superestruturas, o que não é pequena afirmação da 'realidade'. A sua teoria quer exatamente 'fazer tomar consciência' das próprias tarefas, da própria força, do próprio devir de um determinado grupo social. Mas ele destrói as 'ideologias' dos grupos sociais adversários que, na verdade, são instrumentos práticos de domínio político sobre o restante da sociedade" (GRAMSCI, Q. 4, p. 436-437). 
constituindo-se no elemento que materializa a dominação e a subalternidade por meio da formação do modo de vida. Gramsci já alertava para a importância dos jornais na formação da opinião pública e, com os novos meios de comunicação de massa, as condições de consolidação da hegemonia por meio da formação de um horizonte ideológico ${ }^{4}$ unificado que fundamenta o modo de pensar das classes subalternas tomou proporções inusitadas.

Para avaliar a densidade política da noção de hegemonia e como a noção de ideologia faz parte de sua estrutura é necessário ter presente o pano de fundo das reflexões de Gramsci: por um lado, as revoluções do período da Revolução Francesa e de 1848 a 1871, que culminaram no fracasso da Comuna de Paris. Por outro lado, as revoluções passivas que se consolidaram a partir das alianças da burguesia com as classes conservadoras a fim de vencer o movimento operário ascendente. A composição passiva de acordos políticos para consolidar ou manter a hegemonia tornou-se característica especifica da estratégia burguesa no século XX para a solução de crises capitalistas e enfrentamento dos conflitos e da luta de classes. As condições de manutenção da hegemonia mesmo em momentos de grande crise econômica se viabiliza a partir da ideologia como prática de poder.

O objetivo geral desse estudo é partir do conceito de hegemonia a fim de compreender como, no conjunto das relações de forças que constituem a estrutura da sociedade capitalista do século XX e XXI, se explicita a noção de ideologia e seus desdobramentos na formação do senso comum. Nessa senda, pretende-se aprofundar a noção de linguagem, a fim de esclarecer os significados dos conceitos em pauta como estratégias políticas de enfrentamento dos conflitos e de desconstrução da hegemonia dominante. A partir desses fundamentos, pretende-se demonstrar a importância da educação no contexto das relações de hegemonia, principalmente para os subalternos.

A linguagem é, pela formação do senso comum, veículo de difusão de uma ideologia unificadora, por meio da fragmentação do pensamento ou pela divulgação de elementos dispersos e parciais, que escondem as desigualdades sociais e culturais; mas pode ser também instrumento importante para a obtenção de uma nova unidade cultural a partir da organização

4 A expressão "horizonte ideológico" se concretiza na forma de hegemonia burguesa caracterizada como uma ordem social que, para se consolidar, elaborou uma racionalidade que possibilitou construir os aparelhos materiais de produção e "também suas premissas ideológicos-políticas". Para tanto, "destruiu toda a institucionalidade anterior", compreendendo não apenas a sua forma jurídica, mas o adensamento da rede de práticas que constituem, a um só tempo, a individualidade e o coletivo. Esse processo acarretou a naturalização das relações em geral com repercussões na formação do modo de pensar da sociedade, consolidando a total expropriação das classes subalternas: da sua "identidade, dos instrumentos de produção, do conhecimento e dos saberes” (DIAS, 1999, p. 39-40). 
política dos trabalhadores e da superação do silêncio ao qual são reduzidos a partir da assimilação de uma linguagem unificadora. Gramsci intuiu a importância da formação de um pensamento articulado a partir da cultura popular e da organização política dos trabalhadores; somente a organização política permite superar as limitações culturais impostas pela hegemonia dominante, a partir da explicitação das contradições que permeiam o social e da formação de uma concepção crítica e coerente. Conforme Eagleton (1996, p. 196-197), Gramsci ampliou, por meio do conceito de hegemonia, a noção de ideologia, que tomou "corpo material e agudeza política" ao ser transposta para a prática social cotidiana podendo abranger "dimensões inconscientes e não articuladas da experiência social".

Na luta pela hegemonia a linguagem (e, como sua base, a educação em geral) é um instrumento de unificação de uma vontade nacional e esse trabalho é feito pelos intelectuais. A tendência a formar uma elite distante do povo dificulta, para as classes dominantes, manter a hegemonia. Em geral, com o desenvolvimento do capitalismo e a inserção de novas tecnologias de comunicação de massa, bem como com a subordinação dos agentes de comunicação às empresas que os empregam, resolveu-se em grande parte o problema. A produção de um mercado de consumo de cultura de massa (cinema, novelas, best-sellers, etc.) sedimenta a hegemonia a partir da formação de um pensamento homogêneo, que se traduz em comportamentos adequados aos objetivos da hegemonia.

Ora, superar a fragmentação e as contradições da própria concepção do mundo e elaborar uma consciência crítica só pode ser efetuado em grupo, num movimento de organização política, com projetos sociais definidos, processo que passa pela ressignificação da linguagem e aprofundamento do conhecimento da língua nacional. Mesmo quando se assimila a concepção do mundo hegemônica, se possui uma “concepção própria do mundo, ainda que embrionária, que se manifesta na ação e, portanto, descontinua e ocasionalmente”. Enquanto não se desvela o embrionário, fato que só pode ocorrer num movimento político organizado, o subalterno "toma emprestada a outro grupo social, por razões de submissão e de subordinação intelectual, uma concepção do mundo que lhe é estranha”, ou seja, que não expressa o seu cotidiano e seus interesses de classe (GRAMSCI, 1978, Q. 2, p. 1379)5.

Essa questão torna-se fundamental, porque a fragilidade dos subalternos se determina pelo fato de que não possuem uma concepção do mundo

5 A partir deste momento citaremos os Cadernos do Cárcere, de Gramsci, apenas por Q., número do caderno e página da Edição que temos em mãos: Torino, 1978. 
bem elaborada, que expresse seus interesses e suas práticas de classe. Daí a importância da cultura e da educação, bem como da atuação dos intelectuais no contexto do pensamento de Gramsci.

Cabe acentuar que (e essa nos parece ser a grande importância da noção de hegemonia) embora os meios de comunicação de massa consolidem um pensamento homogêneo, um consenso total e cristalizado não existe e a sociedade, em qualquer momento histórico, a bem dizer, vive diferenças ideológicas e visões conflitantes da realidade, que tomam proporções de enfrentamento e de tensão profunda conforme os movimentos de organização política das classes subalternas. É nos momentos de crise econômica e política que as contradições emergem e os conflitos podem tomar proporções radicais, levando a situações em que um consenso se torna impossível. Os caminhos de transformação dessa realidade passam pela apropriação dos mecanismos de direção cultural, de formação intelectual e moral da sociedade, colocando em evidência a educação no contexto das relações de hegemonia.

No caso brasileiro, se pensarmos nos altos índices de analfabetismo (também funcional) entre as classes populares e nas dificuldades de estabelecer a relação entre alfabetização e letramento, enquanto domínio efetivo dos códigos de conhecimento, podemos formar uma ideia da extensão do problema. A inserção de novas tecnologias no processo de educação, sem as bases essenciais do letramento, atua para aumentar as desigualdades sociais.

Na luta pela hegemonia a questão do conhecimento e da linguagem são fundamentais para a conquista da direção intelectual e moral da sociedade. Daí a força hegemônica que emana do controle dos meios de comunicação de massa e da formação de um consenso passivo; no contexto da mundialização do capital e da fusão das grandes potências midiáticas, o controle autoritário e imperialista se instaura de modo sutil e quase imperceptível. Desconstruir esse processo e gerar as condições de transformação social apresenta-se como o grande desafio que, a partir dos escritos de Gramsci, passam tanto pela organização política dos trabalhadores quanto pela formação cultural.

Ora, no contexto das relações de hegemonia e da correlação de forças que caracteriza a luta de classes, o fato de a linguagem ser metafórica permite ressignificar as palavras conforme o momento histórico e a relação de forças em presença, ou seja, assim como os dominantes instrumentalizam a linguagem e a cultura para fins do exercício do poder, a organização política das classes subalternas se apresenta como o meio para elaborar a 
sua concepção de mundo, a sua cultura e a sua linguagem, para assim se apropriar do conhecimento historicamente produzido. Sabe-se que se trata de uma relação extremamente desigual, mas a criação de formas de resistência não é impossível. O possível precisa ser construído a partir da leitura crítica das condições presentes, ou seja, trata-se de inventar, no interior da ação e do discurso burguês, uma nova concepção de mundo a fim de romper os elos de subalternidade tirando proveito das possibilidades metafóricas da linguagem a fim de refutar com destreza o universal legitimador do pensamento único e retomar o conhecimento na sua dimensão histórica.

A questão a ser enfrentada em se tratando da educação é mostrar que, na história, o controle do conhecimento e sua expressão sempre pertenceu aos grupos dominantes representados por elites intelectuais; na sociedade moderna, mais do que nunca, esse poder se multiplicou com a inserção das novas tecnologias de comunicação, de modo que as classes trabalhadoras, para vencer as lutas políticas, precisam se reconhecer no movimento contraditório de construção da sociedade e, para isso, necessitam dominar o conhecimento historicamente produzido para enfrentar o dominador no seu terreno. Gramsci percebia a importância da educação no contexto das relações de hegemonia enquanto caminho de construção da identidade de classe. Para as classes trabalhadoras do início do século XX, a luta pela hegemonia implicava necessariamente fazer a sua leitura da história, a fim de identificar-se como classe e apresentar-se como projeto político e social revolucionário. Esse é o significado pedagógico da organização política, que incluía todas as instituições educativas criadas no movimento de organização da luta de classes.

A metodologia se identifica tanto nos pressupostos teóricos acima esboçados e que se caracteriza na compreensão do particular articulado a uma "base histórica que contenha as premissas materiais" em seu desenvolvimento histórico, a fim de entender o que se esconde por trás das aparências e elaborar um pensamento crítico no qual "dedução e indução sejam combinadas", assim como identidade e diferença, positivo e negativo, abstrato e concreto, sempre com referência ao contexto histórico (Q. 1, p. 34). O trabalho continua sendo o elemento central de socialização e a partir dele se instituem os modos de vida. Mas entender o movimento histórico no qual se produzem e se diversificam as práticas individuais e sociais implica superar as aparências buscando explicitar as relações contraditórias que elas encobrem. A insistência de Gramsci no rigor metodológico, na disciplina como o caminho para construir as condições de liberdade, na aprendizagem 
a partir da historicidade da sociedade, que se torna necessário reconhecer na prática cotidiana de relações que viabilizem a emancipação, são algumas das características da sua concepção de educação que acentuam a relação entre política, história e educação.

Educar-se, para as classes trabalhadoras, da perspectiva gramsciana significa superar as formas de subalternidade. Tendo como pressuposto a dimensão política da cultura e seu lugar na construção e manutenção da hegemonia, uma das formas de subalternidade consiste em permanecer nos limites do cotidiano, presos ao trabalho e à reprodução da vida, ou seja, à materialidade imediata nos limites da ordem instituída ou, no dizer de Gramsci, nos limites do econômico-corporativo. Essas são as bases para o consentimento, que pode não ser consciente, visto que uma das características da subalternidade é a ausência de autonomia na medida em que, a partir da veiculação de um discurso unificado e naturalizado (principalmente pelos meios de comunicação de massa), subtrai-se do indivíduo a capacidade de articular o seu próprio pensamento de modo autônomo.

Diante desse quadro cabe perguntar: como a escola poderia fazer frente a essa situação para criar as condições de formação de um pensamento autônomo? Além de possibilitar o acesso aos códigos e métodos necessários para ler o real, a escola precisaria criar as condições para o individuo se apropriar desse real, ou seja, apreender o conhecimento em sua historicidade. Uma das condições iniciais é superar a crença em uma neutralidade do conhecimento, que determina o que e como pensar, para esclarecer sempre de que ponto de vista se fala e em que contexto tal pensamento se insere (para identificar o embate de ideias). Outra, seria superar os limites do campo discursivo hegemônico (positivista), para que o individuo possa pensar a sua experiência social e a sua historicidade.

A partir dos pressupostos gramscianos aqui definidos nos conceitos de hegemonia e ideologia tem-se condições de entender a dimensão política da educação em geral e da escola em particular. A escola tem uma função no contexto e nos limites postos pela sociedade instituída, mas considerando-se a correlação de forças que caracteriza a construção da hegemonia, pode-se tentar tornar a escola um possível espaço de questionamento da realidade e de busca de novos sentidos.

Em momentos de crise como a que se vive precisamos lembrar que Gramsci, na aridez de seus dias no cárcere, acentuava que "mesmo quando tudo está ou parece perdido, é necessário retomar tranquilamente a obra, 
recomeçando do início” (GRAMSCI, 1975, carta de 12/o9/1927, p. 126). E recomeçar significa, a partir dos pressupostos aqui colocados, compreender o real a fim de elaborar uma teoria política comprometida com transformações radicais, para refletir e criticar as contradições que perpassam seu cotidiano e criar novas opções políticas de mudança.

A atuação da escola na construção dessa nova realidade teria que ir muito além de fornecer instrumentos para o aluno desempenhar uma profissão; a escola precisaria mudar em sua estrutura, conteúdos e métodos, para criar as condições para o aluno reconhecer suas raízes culturais e os valores que transcendem seu tempo, a fim de compreender a sua inserção no mundo. A partir dos escritos de Gramsci nos damos conta da dimensão da luta dos trabalhadores e da importância da formação de uma consciência crítica no momento em que a luta de classes assume um caráter mais acentuadamente ideológico e a palavra se torna um instrumento de luta, visto que os projetos que precisam se materializar na vida cotidiana implicam cada vez mais o domínio da linguagem. Conquistar a hegemonia implica formar um consenso ativo, a fim de conhecer e defender-se dos mecanismos de dominação ideológica para superar o silêncio ao qual somos reduzidos como subalternos.

Nessa nova dimensão política, na qual a formação e a cultura assumem uma importância fundamental, a educação escolar precisa renovar-se para contribuir na criação uma nova sociabilidade. A escola pode contribuir para esta formação, desde que se renove internamente: não apenas mudanças estruturais, que permitam o seu melhor funcionamento, mas mudanças qualitativas, metodológicas e curriculares, que a tornem novamente atraente e importante para as classes trabalhadoras. Esse é um tema que os educadores precisam enfrentar com urgência e Gramsci nos fornece elementos de apoio para essa reflexão.

A estrutura desse trabalho segue a seguinte trajetória:

O primeiro capítulo aborda a questão da hegemonia tanto na crítica gramsciana ao liberalismo quanto na proposição de subversão da praxis identificada por Gramsci na luta de classes e na organização política dos subalternos. O segundo capítulo trata das dimensões da ideologia a partir da leitura gramsciana de Marx e das análises da estrutura econômica e social do início do século XX; a partir desse contexto, observações sobre as novas dimensões da ideologia em nosso tempo e a importância da educação. O capítulo III aborda a questão da linguagem, seus significados e sua 
dimensão política na luta de classes. O quarto capítulo explicita a noção de subalternidade e o capítulo V retoma a questão da educação em geral e a especificidade da educação escolar, bem como sua importância na formação dos trabalhadores. 


\section{CAPÍTULO 1 \\ Às MARGENS DA HISTÓRIA: HEGEMONIA E LUTA DE CLASSES}

Por que o marxismo teve esta sorte de parecer assimilável, em alguns de seus elementos, tanto aos idealistas quanto ao materialismo vulgar? Seria necessário pesquisar os documentos (...) e fazer a história da cultura moderna depois de Marx e Engels (Q. 4, p. 422).

Os 33 Cadernos do Cárcere (4 de traduções e 29 de reflexões políticas) escritos por Antonio Gramsci entre 1929 e 1935, tem como tema central o conceito de hegemonia, ao qual se articulam as noções de ideologia e linguagem. Trata-se de um tema que perpassa os escritos gramscianos e que entendemos de fundamental importância como aporte teórico para entender a conjuntura do capitalismo neste início de século, momento no qual se reavivam as forças mais conservadoras da sociedade tanto no mundo quanto no Brasil.

Queremos precisar que, para nós, Gramsci apresenta-se hoje como um clássico do pensamento moderno, no sentido que escreveu inserindo sua leitura em um contexto histórico determinado, foi interpretado num primeiro momento por Palmiro Togliatti, do qual já se fez a crítica com nova interpretação, seguida posteriormente pelo trabalho fatigoso dos filólogos que preparam a Edição Nacional Italiana, em fase de publicação.

Para explicitar o conceito de hegemonia um dos caminhos é situar o pensamento de Gramsci no contexto das principais polêmicas em torno da natureza da revolução socialista ${ }^{1}$, evidenciando algumas aproximações com Lenin, um tema riquíssimo e, ao mesmo tempo, árido, que exigiria um escrito especifico. A partir de 1917-18, quando o entusiasmo com a Revolução Russa começa a dar lugar a uma reflexão mais profunda, Gramsci inicia a construção do conceito de hegemonia, salientando precisamente a aliança

1 Este tema, que entendemos polêmico, foi desenvolvido no trabalho de pesquisa de tese de Doutorado (2001), onde buscamos as relações de Gramsci com Lenin. Mais recentemente publicamos uma breve introdução aproximativa entre Gramsci e Trotsky a respeito do futurismo (SCHLESENER. 2015). 
operário-camponesa que, conforme Fresu (2008, p. 143), foi uma intuição de Lenin que resultou decisiva na Revolução de Outubro.

No Brasil, Gramsci tem sido interpretado de muitas maneiras diferentes, conforme a inserção política de seus leitores, com polêmicas, controvérsias e críticas unilaterais sobre as formas de apropriação de seu pensamento, que não pretendemos abordar diretamente aqui, embora a nossa posição se esclareça na medida em que explicitamos a noção de verdade contida nos próprios cadernos. Entendemos que não existem proprietários da verdade sobre o texto de Gramsci, primeiro porque o próprio autor acentuou em vários momentos a necessidade de aprofundar bibliografias ou de se certificar de que estava no caminho correto; segundo, porque sua linguagem é metafórica e aberta a novas interpretações; terceiro, porque um texto publicado assume autonomia e abre a possibilidade de novas leituras a partir de novas circunstâncias históricas. Os equívocos nascem da leitura parcial do autor ou da dificuldade de uma reflexão com base no método dialético, como é o caso da separação entre Estado e sociedade civil atribuída a Gramsci e completamente equivocada e, inclusive, criticada pelo próprio autor ${ }^{2}$.

Da nossa parte, nosso trabalho tem sido explicitar o que entendemos ser o contexto histórico do qual Gramsci parte e os desdobramentos teóricometodológicos de sua leitura de Marx e do capitalismo do início do século XX. A questão da hegemonia, que entendemos central e a partir da qual tratamos os demais conceitos, foi abordada por nós em artigos e no livro publicado pela Editora da UFPR (1992) com o título Hegemonia e Cultura, livro com a $3^{\text {a }}$. Edição em 2007. Retomamos o tema porque vemos a necessidade de esclarecer alguns aspectos que nos parecem importantes e, para tanto, tomamos como título desse capítulo o tema do Caderno 25, Às margens da história (história dos grupos sociais subalternos), que abordaremos aqui.

A partir da formação política de Gramsci e sua atuação junto aos Conselhos de Fábrica, salienta-se que a luta de classes implica um processo de formação dos trabalhadores, que se efetiva no movimento de sua organização política; a questão da hegemonia nos Cadernos de Cárcere alimenta-se dessa experiência na medida em que o conceito se aplica tanto à compreensão

2 Um dos momentos em que Gramsci se posiciona criticamente é no Caderno 13, em relação ao economicismo e ao livre câmbio: tais formulações "baseiam-se num erro teórico cuja origem prática não é difícil de identificar, ou seja: baseia-se na distinção entre sociedade política e sociedade civil que, de distinção metódica, é transformada e apresentada como distinção orgânica. Assim, afirma-se que a atividade econômica é própria da sociedade civil e que o estado não deve interferir em sua regulamentação" (Q. 13, p. 1589-9o). A partir destas colocações Dias (2014, p. 20) nos esclarece que a "leitura da sociedade civil como lugar do consenso e em oposição ao Estado não é apenas não- gramsciana, mas profundamente anti-gramsciana". 
das formas de dominação burguesa quanto ao modo como, na correlação de forças, uma nova hegemonia pode ser construída no processo de organização democrática dos trabalhadores. As noções de hegemonia e de democracia, portanto, precisam ser abordadas no âmbito do projeto revolucionário do qual Gramsci participou ativamente, tanto na leitura dos escritos da fase de militância política quanto nos Cadernos do Cárcere onde, no nosso entendimento, a questão da revolução não foi abandonada. Os sinais que nos permitem essa compreensão se encontram nos Cadernos 13, 14, 16, 22 e 25, que serão as bases de leitura deste capítulo, que parte de uma explicitação do significado de hegemonia a partir da crítica gramsciana ao liberalismo.

Para Gramsci, os limites do pensamento liberal se encontram na separação entre economia e política, assim como na estrutura jurídica que sustenta a construção da ideia de democracia. Ao tomar o formal pelo real, o liberalismo consegue criar uma imagem de participação política com base na igualdade dos indivíduos, igualdade que não se efetiva na prática porque ela é profundamente desigual. Esses pressupostos permitem construir determinadas relações de hegemonia que se consolidam como dominação fundada na obediência passiva.

Para Burgio (2014, p. 338-339), a crítica à democracia burguesa efetuada nos Cadernos retoma e aprofunda as críticas desenvolvidas em L'Ordine Nuovo, em que o "aparelho institucional do Estado parlamentar era considerado um bloco funcional para a manipulação da opinião pública e da vontade coletiva", com o objetivo de manter as relações de poder. A democracia burguesa constituía-se, naqueles textos, como "uma estrutura tirânica porque meramente formal”. Restrita "ao 'céu' da política e indiferente diante das desigualdades sociais”. A essa questão vinculamos a crítica de Gramsci aos teóricos das elites, a crítica ao sistema parlamentar, ao individualismo enquanto base da apropriação individual do lucro, assim como a manipulação ideológica das massas que se traduz na formação do consenso e na prática do transformismo.

O segundo item abordado é a função dos intelectuais como comissários da classe dominante para a consolidação e manutenção das relações de hegemonia, enquanto formadores de opinião e mantenedores da coesão social pela formação do senso comum. A terceira parte aborda a questão da luta de classes e suas novas dimensões no contexto das relações de hegemonia e as possibilidades que Gramsci assinala de mudança estrutural do sistema hegemônico com o termo "subversão da praxis". A base para essa abordagem é a metáfora do Centauro retirada de $O$ Príncipe, de Maquiavel, a qual nos 
permite entender a hegemonia enquanto confronto, submissão do mais fraco e mistificação da realidade a partir de um discurso parcial apresentado como universal. O quarto ponto a ser abordado tem como pressuposto as relações de forças ou luta de classes para contrapor subversão da praxis a revolução passiva. Retomamos o Caderno 25 para evidenciar como Gramsci ressalta a luta de classes e os encaminhamentos que os grupos subalternos precisam seguir para enfrentar esta luta em favor de um novo projeto social e político, subversão da praxis, que pode ser entendida como a revolução socialista propriamente dita. Anunciam-se ainda as questões que serão abordadas nos capítulos seguintes em torno da ideologia e da educação.

\section{A hegemonia e suas condições históricas: a crítica gramsciana ao liberalismo}

A tarefa essencial é aquela de empenhar-se sistemática e pacientemente a formar, desenvolver e tornar sempre mais homogênea, compacta e consciente de si a força da qual fazemos parte (Q.13, p. 1588).

A noção de hegemonia encontra-se difusa nos Cadernos do Cárcere, já o conceito de democracia aparece vinculado ao de hegemonia, sendo entendida como um processo político com vínculos ao econômico e cultural, que se desdobram entre o povo ou a nação, podendo efetivar-se em uma "unidade não servil, devida à obediência passiva, mas uma unidade ativa, vivente, qualquer que seja o conteúdo desta vida” (Q. 14, p. 1740). Ao vincular esses dois conceitos Gramsci não esquece que a hegemonia ancora-se na luta de classes e essa, a partir do fracasso da Comuna de Paris ${ }^{3}$, e depois das jornadas de 1848 , tomou novas dimensões na medida em que, para enfrentar a ascensão dos movimentos revolucionários, a burguesia passou a fazer alianças com as classes sociais mais conservadoras, classes que havia enfrentado na Revolução Francesa.

As lutas de classes se modificam com as transformações das relações de força e com as mutações que ocorrem no modo de produção capitalista e nas formas de acumulação do capital pela expropriação da força de trabalho. Tomam novas dimensões também na medida em que a ideologia se transforma em instrumento de formação de um pensamento homogêneo ampliado com a inserção de novas tecnologias de comunicação de massa. 
A partir deste contexto, a noção de democracia tem limites no liberalismo ${ }^{4}$, que vai desde sua dimensão formal, que oculta a realidade de desigualdades sociais, até a forma do regime representativo parlamentar sedimentada na estrutura partidária. Ainda no Caderno 14, com o pretexto da literatura, Gramsci efetua uma breve reflexão sobre a autocrítica e a hipocrisia da autocrítica na literatura, acentuando que muitos tomam por autocrítica belos discursos justificativos que caracterizam, no fundo, uma "parlamentarização" da autocrítica:

[...] O parlamentarismo "implícito (e "tácito") é muito mais perigoso que aquele explícito, porque tem todas as deficiências (do parlamentarismo) sem ter os seus valores positivos. Existe frequentemente um regime de partido "tácito", ou seja, um parlamentarismo "tácito" e "implícito" onde menos se acreditaria. É evidente que não se pode abolir uma "pura" forma, como é o parlamentarismo, sem abolir radicalmente o seu conteúdo, o individualismo, este no seu significado preciso de "apropriação individual" do lucro e da iniciativa econômica para o lucro capitalista individual. A autocrítica hipócrita é precisamente de tais situações (Q. 14, p. 1742).

Esse parágrafo, que inicia com a ideia de "crítica representada pela 'livre' luta política no regime representativo" que pode ser estendida a outras situações, nas quais a crítica se torna presumivelmente mais produtiva em suas consequências (Q. 14, 1742), acentua que o que acontece efetivamente é o contrário: a autocrítica se "parlamentariza" ou seja, assume os vícios do parlamentarismo sem as suas qualidades. Na acentuação do vínculo concreto entre forma e conteúdo se evidencia a relação intrínseca entre o sistema parlamentar e a democracia liberal pela mediação do individualismo que, sedimentado na estrutura econômica fundada na propriedade privada dos meios de produção e na exploração da força de trabalho, estende-se ao modo de vida da sociedade, tomando consistência no senso comum.

Essa questão já tinha sido abordada em 1918, no artigo Spirito associativo, no qual se afirmava a necessidade de superar o individualismo burguês para a formação da própria personalidade na vida coletiva, fortalecendo a

4 Faz-se necessário esclarecer que o que chamamos liberalismo tem uma história de, mais ou menos, cinco séculos, de modo que não existe uma unidade teórica entre os seus representantes, se considerarmos o liberalismo desde J. Locke, passando por Benjamin Constant, Stuart Mill, Adam Smith, e outros, chegando aos contemporâneos teóricos do neoliberalismo, como I. Berlin, F. A. Von Hayek e J. Rawls, para não citar todos. Cabe salientar algumas questões centrais, como a natureza e o alcance das liberdades individuais, a estrutura do Estado e suas funções jurídicas legitimadoras dos direitos individuais e garantidoras do poder político, etc. O contraponto para essas abordagens se encontra em A Questão Judaica, de Marx, pano de fundo para as reflexões de Gramsci sobre a liberdade e sobre como a filosofia de Hegel foi reduzida a "ideologia política imediata, a instrumento de domínio e de hegemonia social" na forma do liberalismo, tendo-se o cuidado de entender que o "termo 'liberal' foi muito ampliado e alcança campos políticos antitéticos” (Q. 8, p. 1007). 
convicção de que, ao contrário do ideário liberal sedimentado no formal, a individualidade se enriquece na troca de experiências com outros homens que pensem da mesma forma. Existem duas formas de espirito associativo: aquele exterior, que agrega os indivíduos sem exigir deles trabalho nem sacrifício e aquele que "tem outros objetivos educativos", na "tentativa de superar o individualismo com maior incremento da personalidade, que se reconhece mais naquilo que tem em comum com os outros" que nas peculiares diferenças acidentais. "É o indivíduo que se enriquece com as experiências de todos os outros homens, que vive as dores e as esperanças dos outros homens, que sente vibrar em si toda a humanidade", alcançando gradativamente a compreensão da categoria de associação internacional (GRAMSCI, 1982b, p.660). Somente a existência da liberdade para todos pode garantir efetivamente as liberdades individuais.

Nos escritos carcerários, um dos momentos em que Gramsci retoma a questão se encontra no Caderno 6, parágrafo 98, a propósito do nascimento do direito moderno, explicitando os limites da estrutura jurídica ampliados pela valorização do formal em detrimento do real concreto: "supõe-se que o direito seja expressão integral de toda a sociedade, o que é falso: a expressão mais consistente da sociedade são aquelas regras de conduta que os juristas chamam 'juridicamente' indiferentes” (Q. 6, p. 773). Na verdade, o direito exprime os interesses da "classe dirigente, que 'impõe' a toda a sociedade aquelas normas de conduta que são mais ligadas à sua razão de ser” (Q. 6, p. 773). Uma das funções primordiais do direito é gerar a crença na igualdade de todos os indivíduos perante a lei, função que não pode realizar na prática porque nesta sociedade fundada na desigualdade social os homens não são iguais e, por consequência, também não são igualmente livres. Desse modo, o direito atua no controle das relações entre "a conduta de cada indivíduo (atos e omissões) e os fins que a sociedade se coloca como necessários”, exercendo uma forma de coerção que não é estatal, no sentido que não é explicitamente política, mas sim de foro moral (Q. 6, p. 757).

Assim como o sistema parlamentar na democracia burguesa produz e reproduz os limites políticos de participação, o direito enquanto um sistema jurídico formal em sentido estrito (tutela da ordem pública, respeito às leis, etc.), atua no âmbito da moralidade e da formação dos costumes morais condicionando determinados comportamentos individuais e sociais; e ambos, parlamentarismo e direito, exercem uma função relevante no exercício da hegemonia na medida em que formam um modo de pensar e de ser. 
Entendemos, a partir desse contexto introdutório, que a questão da hegemonia permeia de ponta a ponta os escritos gramscianos, mesmo quando não explicitamente abordada: os temas da literatura, da linguagem, do jornalismo, do direito, etc., têm como pressuposto a questão política e qualquer leitura de Gramsci é parcial se não for realizada neste horizonte. Como se define hegemonia no Cadernos do Cárcere?

A partir do Caderno 13, parágrafo 37, explicitando a experiência política dos jacobinos na Revolução francesa, Gramsci acentua que no contexto de uma política liberal e do regime parlamentar o "exercício 'normal' da hegemonia" resulta da "combinação da força e do consenso, que se equilibram de modo variado sem que a força supere em muito o consenso" ou então "apareça apoiada sobre o consenso da maioria, expresso pelos assim chamados órgãos de opinião pública - jornais e associações”. O exercício do poder se efetiva como dominação e direção de uma classe social sobre toda a sociedade; domina-se por meio de mecanismos de coerção e dirigese pela formação do consentimento. Nesse contexto histórico de formação do Estado burguês, o sistema parlamentar funcionava por deliberação e as forças políticas divergentes se confrontavam no processo de elaboração da legislação ordinária, bem como instauravam "o emprego mais ou menos extensivo dos decretos-leis", que tendiam a substituir ou a modificar a legislação ordinária, de acordo com os interesses que predominavam na disputa política (Q. 13, p. 1638).

No curso da história moderna esses mecanismos se renovaram ou se aperfeiçoaram, de modo a caracterizar tanto a força deste sistema quanto a sua fragilidade, que aparece nos momentos de crise política. Ainda a propósito do movimento francês, Gramsci acentua que, depois da primeira guerra mundial, esse aparato hegemônico se despedaça tornando difícil o exercício da hegemonia. O fenômeno vem identificado como "crise de autoridade", “dissolução do regime parlamentar", falência dos "princípios” morais, etc. "A crise se apresenta praticamente na sempre crescente dificuldade de formar os governos", bem como na "crescente instabilidade dos governos" instituídos. As causas podem ser várias e a crise pode estender-se por longos anos, tornando-se necessário resolvê-la para consolidar a hegemonia (Q. 13, p. 1639).

As soluções para a crise, na leitura de Gramsci a partir da análise do Risorgimento italiano, passam pela recomposição parlamentar e pela aplicação do mecanismo de transformismo, um instrumento político que se tornou recorrente na estrutura parlamentar italiana e que supõe a absorção 
pela classe dominante dos eventuais líderes nascidos dos movimentos de resistência dos subalternos, por meio de acordos, busca do consenso, compromisso pela unidade, etc. Entretanto, pela própria estrutura do sistema parlamentar no contexto da democracia burguesa, essas soluções são paliativas, visto que a representação desse sistema não traduz os interesses reais de toda a sociedade, mas sim interesses de classe, dissimulados na ideia de representação geral.

Como acentua Burgio (2014, p. 339), para Gramsci a "esfera política é caracterizada por uma dimensão pública meramente abstrata” e privada, enquanto o "funcionamento concreto dos poderes favorece o domínio de círculos restritos”. Essa ação restrita do sistema parlamentar acontece porque "a 'democracia burguesa' repousa sobre a cisão entre esfera política e realidade social, cisão que o sistema 'parlamentar' tem a função de mascarar, legitimar e perpetuar".

No Caderno 13, a articulação entre econômico-social, político, ideológico se apresenta na afirmação de que: [...] se a hegemonia é ético-política, não pode deixar de ser também econômica, não pode deixar de ter seu fundamento na função decisiva que o grupo dirigente exerce no núcleo decisivo da atividade econômica (Q. 13, p. 1591). No Caderno 14 essa relação se reafirma na forma do "parlamentarismo que, sem abolir radicalmente o seu conteúdo", se respalda no "individualismo, este no seu preciso significado de 'apropriação individual' do lucro e da iniciativa econômica para o lucro capitalista individual” (Q. 14, p. 1742).

A questão implícita nessa primeira definição de hegemonia é sobre a estrutura do Estado e os mecanismos para o exercício do poder. Muito se escreveu sobre o Estado ampliado gramsciano, a maioria das leituras separando didaticamente a sociedade política da sociedade civil. Conforme Dias (2012), essa separação é anti-gramsciana, visto que abre a senda para uma leitura liberal de Gramsci, tanto na separação entre economia e política quanto nos desdobramentos da noção de hegemonia e na luta de classes.

Do mesmo modo, Burgio (2014, p. 202) acentua que essa separação, em seu esquematismo e mecanicidade, "foi herdada do marxismo vulgar" e essa ideia não é outra coisa senão a réplica do esquema liberal que "atribui ao Estado o poder de plasmar (e oprimir) a sociedade”. A essa ideia, Gramsci opõe a "assimetria entre os dois planos", numa relação dialética de interação entre eles. Um desses momentos em que a questão da estrutura 
do Estado enquanto relação intrínseca entre sociedade política e sociedade civil é abordada no Caderno 12:

Pode-se, por agora, fixar dois grandes "planos" superestruturais, aquele que se pode chamar "sociedade civil", isto é, o conjunto de organismos vulgarmente chamados "privados" e aquele da "sociedade política ou Estado", que correspondem à função de "hegemonia" que o grupo dominante exerce em toda a sociedade e àquela de "domínio direto" ou de comando que se exprime no Estado e no governo “jurídico". Estas funções são precisamente organizativas e conectivas (Q.12, p. 1518-19).

Esses dois "planos" superestruturais se articulam pela mediação dos intelectuais, que são "os 'comissários' do grupo dominante para o exercício das funções subalternas da hegemonia social e do governo político”, efetuando a relação intrínseca entre a atividade da sociedade política e as várias instâncias da sociedade civil, ou seja, a sociedade política exerce o “domínio direto" por meio da estrutura burocrática e das funções de governo, enquanto a formação do consenso se efetiva por meio dos veículos de comunicação de massa e outras instâncias da sociedade civil:

1) do consenso "espontâneo" dado pelas grandes massas da população à orientação dada à vida social pelo grupo fundamental dominante, consenso que nasce "historicamente" do prestígio (e, portanto, da confiança) conseguidos pelo grupo dominante a partir de sua posição e de sua função no mundo da produção; 2) do aparato coercitivo estatal que assegura "legalmente" a disciplina daqueles grupos que não "consentem", nem ativa nem passivamente (Q. 12, p. 1519).

Essa articulação entre os dois "planos" da superestrutura se explicita no Estado na divisão de poderes, "resultado da luta entre sociedade civil e sociedade política num determinado período histórico", traduzida em crise que expressa "um equilíbrio instável das classes, determinado pelo fato que certas categorias de intelectuais" são ainda muito ligadas às velhas classes dominantes. Toda a "ideologia liberal, com sua força e suas fragilidades, pode estar contida no princípio da divisão de poderes"; sua principal fragilidade "é a burocracia, ou seja, a cristalização do pessoal dirigente que exerce o poder coercitivo e que, a um certo ponto, torna-se casta” (Q. 6, p. 752)

O que possibilita a manutenção do pessoal dirigente é a estrutura dos partidos políticos que, no contexto do liberalismo e do sistema jurídico que

5 Gramsci cita exemplos da Franca e da Itália do século XIX, mas parece falar da estrutura do Estado brasileiro, tanto no executivo, quanto no legislativo e no judiciário. A divisão de poderes e o sistema jurídico que garantem o funcionamento dessa forma de democracia que se consolida na burocracia e no sistema de "castas", que se verifica na permanência dos políticos nos cargos, que depois passam para os filhos e netos, por meio do sistema partidário ineficiente e eleitoreiro. 
o sustenta, tornam-se instrumentos eleitoreiros pelos quais os políticos se perpetuam no poder independentemente de sua atuação em favor dos seus eleitores. Um partido político dinâmico precisa manter e alimentar os elos entre dirigentes e massa popular. A tendência, porém, é o distanciamento dos dirigentes, possibilitada pela própria estrutura partidária no contexto da democracia burguesa, o que torna os partidos instituições burocráticas, "anacrônicas e mumificadas" (Q 7, p. 910).

"A debilidade dos partidos políticos italianos, em todo o período de atividade, do Risorgimento em diante, consistiu no que se poderia chamar um desequilíbrio entre a agitação e a propaganda e que, em outros termos, se chama falta de princípios, oportunismo, falta de continuidade orgânica, desequilíbrio entre tática e estratégia, etc. A causa principal deste modo de ser dos partidos se deve buscar na delinquência das classes econômicas, na estrutura econômica e social gelatinosa do país, o que é uma explicação fatalista; de fato, se é verdade que os partidos não são mais que nomenclaturas das classes, também é verdade que os partidos não são somente uma expressão mecânica e passiva das próprias classes", mas contribuem para o desenvolvimento das classes (Q. 3, p. 386-7).

Esses limites e fragilidades dos partidos políticos se vinculam ao conjunto da estrutura legal e jurídica que separa formal e real, economia e política, sociedade política e sociedade civil. A estrutura parlamentar permite que o governo se coloque "acima dos partidos, não para harmonizar seus interesses e a atividade nos quadros permanentes da vida e dos interesses estatais", mas para desagregá-los e afastá-los das massas, como acontece com o fenômeno do transformismo (Q. 3, p. 387). Esse fenômeno, em seu sentido clássico, contribuiu para a unificação dos partidos durante o Risorgimento, esclarecendo a relação entre "civilização, ideologia e força de classe" (Q. 3, p. 396).

Ao movimento de redução do alcance político dos partidos vinculase também a questão burocrática, que não somente afasta os partidos das massas, mas a burocracia pode tornar-se, a partir do controle administrativo,

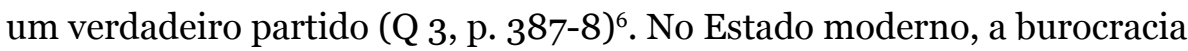
assumiu formas diversas e, no liberalismo, constituiu-se na sua debilidade enquanto cristaliza o "grupo dirigente que exerce o poder coercitivo e que, em certo momento, torna-se casta”. Daí decorre a legitimidade da reivindicação

6 Neste ponto Gramsci lembra a necessidade de consultar os livros de Max Weber sobre Parlamento $e$ Governo na nova ordem da Alemanha e Crítica Política da burocracia e da vida dos Partidos, traduzidos em italiano. 
popular pela "elegibilidade de todos os cargos públicos, reivindicação que é o extremo liberalismo e, ao mesmo tempo, a sua dissolução” (Q. 6, p. 752)7.

Gramsci aborda essas questões em outros momentos, como no Caderno 13, onde acentua que a definição liberal do Estado "baseia-se em um 'erro teórico’ do qual não é difícil identificar a origem prática”: tem como base a "distinção entre sociedade política e sociedade civil que, de distinção metodológica, é transformada e apresentada como distinção orgânica”. A partir deste erro, o pensamento liberal pode afirmar que "a atividade econômica é própria da sociedade civil e que o Estado não deve intervir na sua regulamentação". Porém, na "realidade efetiva sociedade civil e Estado se identificam" pode-se dizer que também o liberalismo se apresenta como "uma 'regulamentação' de caráter estatal introduzida e mantida por via legislativa e coercitiva" (Q. 13, p. 1590). Portanto, a separação entre economia e política, assim como a separação entre sociedade política e sociedade civil, apresentam-se como mecanismos ideológicos de mascaramento das reais funções do Estado enquanto garantidor dos interesses dos grupos dominantes.

Além do ordenamento de base jurídica que objetiva garantir direitos subjetivos, a partir do qual se consolida um conceito de liberdade individual restrito ao agir autônomo na esfera privada, outro pressuposto para o exercício da hegemonia no contexto de um Estado liberal é a separação (real e não formal) entre economia e política, que garante a livre iniciativa da economia na esfera privada e no mercado. Esses princípios permitem elidir a real função do Estado no contexto da luta de classes e gerar no imaginário social a crença de que o Estado pode garantir para todos os direitos individuais e as condições efetivas do exercício da liberdade subjetiva. Da perspectiva jurídica, explicita-se em que consiste a livre atividade dos sujeitos, sempre de modo abstrato porque sem qualquer referência às desigualdades sociais.

Já nos escritos políticos de 1916-1918 Gramsci procura mostrar os limites da liberdade individual e da garantia dos direitos pelo Estado a partir da estrutura do modo de produção capitalista, cuja base é a propriedade privada dos meios de produção e a exploração da força de trabalho, vinculadas a um individualismo meritocrático. Nesse contexto, "ser senhor da vida significa

7 "Unidade do Estado na distinção dos poderes: o Parlamento mais ligado à sociedade civil, o Poder Judiciário entre Governo e Parlamento representa a continuidade da lei escrita (também contra o Governo). Naturalmente todos os três poderes são também órgãos de hegemonia política, mas em medida diversa: 1) Parlamento; 2) Magistratura; 3) Governo. É de se notar que ao público faça impressão desastrosa especialmente as transgressões da administração da justiça: o aparelho hegemônico é mais sensível neste setor, que também pode incluir os representantes da polícia e da administração política” (Q. 6, p. 752). 
tornar-se rico conquistar a própria liberdade", ou seja, a liberdade é medida pela posse e o ideário liberal transfere a responsabilidade da ascensão social (e seu consequente fracasso na competição desigual) para as capacidades individuais entendidas como próprias da natureza de cada indivíduo. $\mathrm{E}$ a questão se apresenta não como busca do enriquecimento que, da perspectiva moral (e religiosa) poderia significar avareza, mas sim como busca da liberdade (que, no âmbito do capitalismo, se restringe ao poder econômico como forma de ter acesso aos demais direitos) (GRAMSCI, 1975, p. 214).

O que Gramsci procura mostrar é que a separação entre forma e conteúdo efetivada pelo pensamento liberal toma uma dimensão política e ideológica que alimenta o senso comum, com grande poder mistificador da realidade social. No seu imaginário social, tendo assimilado o individualismo e a ideia de meritocracia, que fundamentam as relações sociais na sociedade capitalista, o sujeito acredita poder ascender socialmente por meio de seu trabalho, visto que se entende como alguém que precisa (e que pode) vencer com suas próprias capacidades ${ }^{8}$.

Na medida em que o pensamento liberal separa economia de política, omite a verdadeira função do Estado moderno, que é a de garantir o desenvolvimento econômico e os interesses da classe no poder; a valorização da livre iniciativa na esfera privada a partir das capacidades individuais oculta os liames entre capital e Estado, que permitem implementar mecanismos sempre mais sofisticados de exploração da força de trabalho e depredação dos recursos naturais, além de atribuir à consciência e à ação individual as causas dos fracassos nas tentativas de ascensão social.

Nos Cadernos do Cárcere 10 e 11 a questão se apresenta na explicitação da relação intrínseca entre política, economia e cultura, posicionando-se no âmbito das interpretações revisionistas de Marx, tanto por parte de Benedetto Croce em sua interpretação especulativa e liberal do marxismo

8 "Aqui está: a liberdade. Detenhamo-nos. Certamente a riqueza não é um fim; se se torna fim chama-se avidez (avareza). É meio para um fim: a liberdade. Um vintém que você possua, é um vintém de liberdade à sua disposição, é um vintém de livre escolha. A propriedade é a garantia de que esta liberdade será contínua. A propriedade de uma parte de riqueza (instrumento de trabalho) é a possibilidade de ampliar ainda mais o domínio da liberdade pessoal. O direito de herança é a garantia de que a sua liberdade pessoal será também de seus filhos, dos seus entes queridos. Uma vez que o seu fim não é um fato material circunscrito, uma vez que você não é um ávido de bem estar mecânico, mas de liberdade, resulta que o seu objetivo não é individual, mas é a imortalidade. [...] Todos os homens têm esta aspiração, todos os homens querem tornar-se proprietários de liberdade, de liberdade garantida, de liberdade transmissível. Se ela é o sumo bem, é natural que dela se procure fazer participantes os próprios entes queridos, é natural que se aceite o sacrifício para criar esta liberdade, ainda que certos de não aproveitá-la para si próprios, só para assegurá-la aos entes queridos. [...] Mas a liberdade é somente um privilégio: eis porque se manifestam estas perversões. A sociedade é um mercado: a sorte é um jogo. A maioria deve necessariamente fracassar na feroz competição" (GRAMSCI, 1975, p. 214-217). 
quanto a partir do Ensaio Popular de Bukharin. Pode-se "dizer que uma grande parte da obra filosófica de B. Croce representa a tentativa de reabsorver a filosofia da praxis e a incorporar, como serva, à cultura tradicional. Mas como se vê no Ensaio, também os que se chamam 'ortodoxos' da filosofia da praxis caem na armadilha" ao conceberem a sua filosofia "como subordinada a uma teoria geral materialista (vulgar), como outros àquela idealista" (Q. 11, p. 1435) ${ }^{9}$.

Na crítica ao economicismo, Gramsci acentua que o "fato de que a hegemonia sem dúvida pressupõe que se considerem os interesses e as tendências dos grupos sobre os quais a hegemonia é exercida" e que, em qualquer circunstância, a hegemonia se funda na estrutura material, ou seja, "não pode não ser econômica, não pode deixar de ter o seu fundamento na função decisiva que o grupo dirigente exerce no núcleo decisivo da atividade econômica" (Q. 13, p. 1591).

A peculiaridade da filosofia da praxis é que ela é "revolucionária", precisamente porque articula econômico, político e ideológico, mostrando a sua interdependência, ou seja, inova em todos os sentidos: é uma "estrutura de pensamento completamente autônoma e independente" de tudo o que foi anteriormente produzido; ${ }^{10}$ "contém em si todos os elementos fundamentais para construir uma concepção de mundo total e integral”, capaz de "vivificar uma organização prática integral da sociedade" e criar uma nova civilização (Q. 11, p. 1434).

Essa originalidade e superação de toda teoria anterior ocorre pela relação que a filosofia da praxis instaura entre economia, política e história (ou economia, política e filosofia). Trata-se de uma questão de método pela qual se acentua a tradutibilidade entre esses três elementos da teoria, que precisam ser abordados em sua relação e reciprocidade.

Se estas três atividades são os elementos constitutivos necessários de uma mesma concepção de mundo, necessariamente deve haver, nos seus princípios teóricos, convertibilidade de uma em outra, tradução recíproca na própria linguagem especifica de cada elemento constitutivo: um está

\footnotetext{
9 Os revisionismos criticados por Gramsci, na realidade, atacam os três pilares que sustentam a teoria marxiana, que são o método dialético, a teoria da mais valia que expressa o mecanismo da exploração do trabalho e a questão do socialismo. Gramsci aborda essas questões em vários pontos dos Cadernos.

10 Embora não se deva esquecer as origens, ou seja, que a filosofia da praxis se alimentou das ideias de Spinoza, de Hegel, de Feuerbach, bem como do materialismo francês, etc., superando estas filosofias em uma nova síntese que se apresenta como uma nova filosofia; trata-se de uma "filosofia original não apenas enquanto supera as filosofias precedentes, mas especialmente enquanto abre um caminho completamente novo, isto é, renova de cima a baixo o modo de conceber a própria filosofia” (Q. 11, p. 1436).
} 
implícito no outro e todos juntos formam um circulo homogêneo (Q. 11, 65, p. 1492).

Da conversibilidade dessas proposições seguem-se alguns critérios de pesquisa que são fundamentais e que distinguem a filosofia da praxis de todo o pensamento anterior, entre eles o de tomar a teoria como suporte para explicitar o movimento histórico de posição e superação das contradições, de análise de conjuntura, de esclarecimento das múltiplas determinações (econômicas, sociais, políticas, ideológicas) que formam a individualidade dos sujeitos que interagem entre si.

O entrelaçamento e a conversibilidade entre política, economia e história permitem explicitar a relação dialética entre estrutura e superestrutura: conforme o Caderno 4 parágrafos 12, retomado e ampliado no Caderno 11, é importante explicitar os significados desses conceitos para fazer frente aos dois revisionismos de Marx; a "complexidade desta questão se percebe nisso: as bibliotecas são estrutura ou superestrutura?” E o que dizer do gabinete de um cientista ou de um instrumento musical? "Confunde-se estrutura com 'instrumento material' em geral e 'instrumento técnico' com qualquer instrumento material", chegando-se a "sustentar que uma determinada arte se desenvolveu porque foram desenvolvidos os instrumentos específicos" para aquela expressão artística. "Não se pode negar que existe uma relação, mas não imediata". Na realidade "certas formas de instrumento técnico tem uma dupla fenomenologia: são estrutura e superestrutura" ao mesmo tempo (Q. 4, 12, p. 433). Ora, o mesmo acontece com o entrelaçamento entre a economia, a política e a história (ou filosofia, cultura, etc.):

Uma classe forma-se sobre a base de sua função no mundo produtivo: $o$ desenvolvimento e a luta pelo poder e pela conservação do poder criam as superestruturas que determinam a formação de uma 'estrutura material especial' para a sua difusão, etc. O pensamento cientifico é uma superestrutura que cria os 'instrumentos científicos'; a música é uma superestrutura que cria os instrumentos musicais. Logicamente e também cronologicamente se tem: estrutura social -superestrutura - estrutura material da superestrutura (Q. 4, p. 434).

A relação entre estrutura e superestrutura em determinado movimento histórico é retomada no Caderno 13, parágrafo 17, nas considerações sobre o Prefácio à Crítica da Economia Política, escrito por Marx e publicado em 1859, enquanto um problema "que precisamos colocar e resolver exatamente para alcançar uma justa análise das forças que atuam na história”. Para tanto, é preciso "mover-se no âmbito de dois princípios: 1) que nenhuma 
sociedade se coloca tarefas para cuja solução ainda não existam as condições necessárias e suficientes" [...] 2) que "nenhuma sociedade se dissolve e pode ser substituída antes que se tenham desenvolvido todas as formas de vida implícitas em suas relações" (Q. 13, 17, p. 1579) ${ }^{11}$.

Esses dois princípios fundamentam uma série de outros no que se refere a uma metodologia histórica que permita identificar e distinguir os "movimentos orgânicos (relativamente permanentes) dos movimentos que se pode chamar de conjunturais (e que se apresentam como ocasionais, imediatos ou quase acidentais)". Essa precisão metodológica é muito importante porque permite distinguir os fenômenos de menor abrangência histórica e referentes ao cotidiano social e político dos fenômenos orgânicos, os quais possibilitam efetuar a crítica histórico-social, identificando os grupos em presença e as relações de forças que acontecem em determinado momento histórico (Q. 13, p. 1579).

Identificar esse movimento e o conjunto de articulações por ele produzido permite perceber as relações de força que garantem a hegemonia de um grupo social sobre toda a sociedade, bem como as contradições que permeiam a estrutura e que as forças políticas não conseguem resolver ou superar, caindo em crises de hegemonia muitas vezes prolongadas. As crises podem revelar, entre outros fatores, o esgotamento das propostas dos grupos dominantes e geram as condições para a organização política das “forças antagônicas que tentam demonstrar [...] que já existem as condições necessárias e suficientes para realizar determinadas tarefas” (Q. 13, p. 1580).

A articulação entre economia e política, conjuntura e estrutura, cotidiano e totalidade, identificados no movimento histórico das forças sociais em presença, dos fatos históricos concretos, permitem demonstrar que a eficiência da economia liberal não reside no mérito individual dos donos dos meios de produção, mas na exploração da força de trabalho com o respaldo do Estado, o qual direciona os recursos públicos em beneficio do desenvolvimento econômico. A definição do Estado em sentido restrito, como aparato de governo e forma jurídica, permite mascarar os mecanismos de controle social e de formação do modo de pensar que se instituem na sociedade civil enquanto parte do Estado.

11 Entre parênteses Gramsci escreveu que era preciso verificar se a enunciação desses princípios estava correta. Essa observação nos sugere que a inversão dos princípios pode não ter sido intencional. Entretanto, a substituição de "forças produtivas" por "formas de vida", assim como de "condições materiais" por "condições necessárias e suficientes", altera substancialmente o conteúdo desses dois princípios, fato que pode ser entendido como intencional se considerado no contexto da proposição gramsciana de articulação entre economia, política e filosofia ou no âmbito das reflexões sobre relações de hegemonia. 
No Caderno 7, parágrafo 24, tem-se outra abordagem da relação estrutura e superestrutura, desta vez a propósito da relação entre economia e ideologia na crítica ao revisionismo mecanicista: a tentativa de "apresentar e expor cada flutuação da política e da ideologia como expressão imediata da estrutura, deve ser teoricamente combatida como um infantilismo primitivo, ou praticamente deve ser combatida com o testemunho autentico de Marx, escritor de obras políticas e históricas concretas”. Nesse contexto, "são importantes especialmente $O 18$ Brumário e os escritos sobre a Questão Oriental, mas também outros (Revolução e Contrarrevolução na Alemanha, A Guerra Civil na França)"; a leitura desses textos "permite fixar melhor a metodologia histórica marxista integrando, iluminando e interpretando as afirmações teóricas difusas em todas as obras" (Q. 7, p. 871).

Gramsci ainda recomenda muita cautela na abordagem dos conceitos, principalmente pela dificuldade em identificar a cada momento a estrutura e seus desdobramentos na política: uma "fase estrutural pode ser concretamente estudada e analisada somente depois de haver superado todo o seu processo de desenvolvimento" e, durante o processo, somente por hipótese, com a recomendação de "declarar explicitamente que se trata de hipótese". Todas as avaliações efetuadas no curso do processo devem ser consideradas provisórias e precisam ser constantemente atualizadas, sempre levando em conta que nós próprios estamos inseridos nesse processo e, portanto, nossa avaliação se efetua de uma determinada perspectiva. Deduz-se daí que "uma determinada ação política pode ter sido um erro de cálculo da parte dos dirigentes da classe dominante, erro que o desenvolvimento histórico, por meio das 'crises' parlamentares governativas das classes dirigentes corrige e supera”. A leitura determinista do "materialismo histórico mecânico não considera a possibilidade de erro, mas assume cada ato político como imediatamente determinado pela estrutura" (Q. 7, p. 872).

Dessas duas situações decorre uma terceira, ou seja, impossível haver uma explicação imediata, primária, na estrutura, das ações políticas; é preciso considerar que "muitas ações políticas se devem a necessidades internas de caráter organizativo ligado a uma necessidade de dar coerência ao partido, ao grupo social ou a uma sociedade"; somente no movimento histórico concreto e passado o processo se pode esclarecer as relações de forças que se confrontam, a relação entre o desenvolvimento das forças materiais de produção e as ações políticas que colocam em crise ou consolidam uma hegemonia (Q. 7, p. 872-873). 
Essas observações de Gramsci são fundamentais para se entender a questão da hegemonia para além do mais divulgado e conhecido na leitura liberal dos escritos de Gramsci ${ }^{12}$. A hegemonia é uma forma de dominação (e até de aliciamento) no contexto da luta de classes, mas a partir do aprofundamento da questão do método e da crítica gramsciana às interpretações revisionistas de Marx pode-se entender a hegemonia numa perspectiva revolucionária.

No Caderno 19 a hegemonia vem definida do seguinte modo:

a supremacia de um grupo social se manifesta de duas maneiras: como 'domínio' e como ‘direção intelectual e moral'. Um grupo social é dominante dos grupos adversários que tende a 'liquidar' ou a submeter inclusive com a força armada e é dirigente dos grupos afins e aliados (Q. 19, p. 2010).

Conquistar a direção intelectual e moral torna-se fundamental já antes da tomada do poder, mas de modo algum o uso da força está descartado.

A força pode ser entendida de modo restrito como "liquidar e submeter com a força armada", mas se encontra também no submeter pela obediência, pela censura, pela repressão moral, visto que a educação, a cultura, a religião, a ideologia, tornam-se instrumentos de formação de opinião pública para alcançar um consenso passivo. Como acentua Dias (2014, p. 20), "quando falamos em consenso imaginamos 'acordo'. Contudo consenso pode ser encarado como obter o consentimento, isto é, obter a obediência”. Essa exprime uma situação social desigual, mascarada por um discurso jurídico de igualdade formal. A força mistificadora da ideologia permite um "consentir sem consenso", ou seja, o jogo político apoiado na ambiguidade das palavras ou no seu significado parcial e abstrato, que esconde significados diversos e até opostos. Também Burgio (2014, p. 208), citando o Caderno 6, afirma que o domínio se consolida na sociedade civil, cujo caráter de classe, também mistificado, permite fortalecer os instrumentos de luta política como parte do aparato hegemônico da classe dominante. Os cadernos "são muito claros e unívocos" quando "definem a sociedade civil como sistema de 'hegemonia política e cultura de um grupo social sobre toda a sociedade' ".

No processo de construção e conservação da hegemonia, o "Estado, quando quer iniciar uma ação pouco popular, cria preventivamente a opinião pública adequada, isto é, organiza e centraliza certos elementos da

12 Entendemos como liberal a leitura de Gramsci que não apenas dissocia sociedade política de sociedade civil, a coerção do consenso, numa oposição dicotômica, como atribui à sociedade política, implicitamente identificada com o Estado, posição que supõe a separação entre economia e política entendendo esta como a simples função de governo. 
sociedade civil”. Com os novos meios de comunicação de massa surgidos na modernidade, a formação do consenso passivo por meio da formação da opinião pública tomou dimensões desmesuradas. Gramsci define a opinião pública como "o conteúdo político da vontade política pública que poderia ser discordante" e, para isso, o monopólio dos meios de formação da opinião pública (jornais, partidos, parlamento) se torna fundamental, tanto para alcançar um consenso passivo quanto para dispersar os discordantes e dificultar a sua organização em movimentos consistentes (Q. 7, p. 914-915).

Esse problema tomou dimensões inusitadas na modernidade, com a difusão da ideologia como prática de poder. Explicitar essa questão exigiria passar por autores como Marx e os desdobramentos do marxismo para chegar ao contexto da educação enquanto formação para um modo de vida no âmbito social e político. Conforme Eagleton (1997, p. 100), "se a crítica da ideologia propõe-se a examinar os fundamentos sociais do pensamento", deveria "ser capaz de fornecer alguma explicação de suas próprias origens históricas”. Não se trata aqui de buscar tais origens, embora a filosofia da praxis nos ofereça as condições para tanto. O que nos interessa aqui é mostrar as formas como a ideologia se vincula à questão da hegemonia, tornando-se seu instrumento para reforçar as condições de dominação.

O liberalismo, portanto, tem um programa político que visa a "modificar não a estrutura do Estado, mas sim a sua orientação governamental” e gerar uma alternância no poder a fim de fazer as modificações necessárias para o desenvolvimento do comércio e da indústria de acordo com os interesses dos grupos dominantes (Q. 13, p. 1590). A hegemonia se consolida na medida em que se forma o imaginário social baseado nas expectativas criadas por seu ideário ideológico, que oculta a real função do grupo dirigente em relação à consolidação e manutenção das atividades econômicas capitalistas.

Essa situação serve perfeitamente para cooptar lideranças surgidas dos movimentos de resistência dos trabalhadores, caso que Gramsci explicita na sua abordagem do Risorgimento, no fato que, naquela situação, a absorção de dirigentes e mesmo de grupos inteiros para o campo moderado ocorreu tanto porque o Partido Moderado era a vanguarda orgânica real daquele movimento e tinha consciência crítica de sua missão quanto porque as lideranças do Partido da Ação, em consequência das ambiguidades e oscilações características de sua situação de classe (intelectuais, artesãos, pequena-burguesia), não tinham clareza de sua função histórica. Essa diferença em compreender o processo histórico de modo claro e abrangente tinha como 
base tanto os elos dos grupos dirigentes com as classes sociais em disputa quanto o ideário mistificador que se concentrava nos lemas "independência e unidade", quando a situação histórica era de fragmentação política e desigualdade social intensa, ou seja, sem precisar o conteúdo desses conceitos. Com essas palavras de ordem "os moderados conseguiram seu intento de desviar a atenção do núcleo para a casca” e cooptar os dirigentes do Partido da Ação que poderiam, de outra forma, aliar-se aos movimentos populares em suas reivindicações mais progressistas. As consequências históricas dessas alianças ocorridas no processo de unificação italiana foram a repressão dos movimentos populares e o aprofundamento das desigualdades sociais entre Norte e Sul, desaguando na questão meridional (Q. 19, p. 2014 ss.).

Essa abordagem da hegemonia tem sido a mais conhecida dos escritos de Gramsci. Podemos verificar que nos Cadernos do Cárcere pode-se encontrar outra definição de hegemonia, que contempla as forças de resistência ao instituído e a possibilidade de movimentos insurrecionais. Gramsci reflete sobre a possibilidade revolucionária no contexto da nova configuração do capitalismo a partir dos novos mecanismos ideológicos de formação do consenso e as novas dimensões da luta de classes, que exigem ampliar a organização política no seu aspecto educativo, vistas as novas formas de submissão e dominação na formação da subjetividade. No movimento de relações de forças políticas o acirramento dos conflitos gera a possibilidade de esclarecer a natureza contraditória das relações econômicas e sociais na formação da autoconsciência das massas trazendo para a atualidade a perspectiva revolucionária. A luta pela hegemonia é desigual, mas os Cadernos apontam possibilidades e alternativas no movimento dialético no qual os grupos subalternos precisam se organizar e retomar a luta pela formação de uma nova ordem social e política.

\section{A função dos intelectuais na construção/manutenção da hegemonia}

No cárcere, Gramsci raciocina, como nós, a partir de uma derrota. Isso é o que o torna assim tão precioso para quem resiste à ideia de que a derrota implique também o impedimento de raciocinar

(MORDENTI, 2007, p. 39).

O interesse de Gramsci pela questão dos intelectuais já aparece nos Escritos Políticos de 1916-1926, explicitando-se no seu texto de 1926 sobre hegemonia com o título A Questão Meridional. Nesse escrito que ficou incompleto, os intelectuais desempenham uma função importante na 
organização social e política italiana, no sentido de consolidar relações de dominação. Nos Cadernos do Cárcere a questão meridional assume uma nova dimensão a partir da perspectiva conservadora do Risorgimento, que desencadeou um modo de produção capitalista alicerçado na exploração dos recursos naturais e humanos do Sul da Itália. ${ }^{13}$ No curso dos Cadernos Gramsci retoma a temática e examina a função dos intelectuais na consolidação da hegemonia burguesa concentrada no Norte e como esses intelectuais atuam, tanto nas funções burocráticas do Estado quanto na formação do consenso (principalmente os chamados "grandes intelectuais", como Croce e Fortunato, oriundos do Sul) pela contínua direção exercida por meio dos escritos nos jornais cotidianos. Desta forma, centralizam e controlam o conjunto de manifestações sociais e políticas do Sul e contribuem para a formação do senso comum dominante ${ }^{14}$.

Gramsci (Q. 6, p. 689) acentua que os grandes intelectuais italianos, se quiserem continuar a ser atuais, precisam adaptar-se às mudanças históricas e sociais, ou seja, no contexto da sociedade moderna, da qual participam ativa e diretamente massas humanas cada vez mais amplas, os intelectuais precisam democratizar-se, "mergulhar na vida prática, tornarse organizadores dos aspectos práticos da cultura, se quiserem continuar a dirigir"; não é mais possível, no mundo moderno, uma atitude intelectual como a do Renascimento.

As formas de luta de classes se alteram na medida em que os meios de comunicação de massa contribuem para consolidar a hegemonia tendo como instrumento a formação de um pensamento homogêneo que se traduz em um consenso passivo. Nesse contexto, atuam os intelectuais como comissários da hegemonia, ou seja, formadores de opinião e mantenedores da coesão pela formação do senso comum. Utilizando-se da fragmentação do pensamento, de teorias que entram e saem de moda como novas interpretações do real, mas que se delimitam pela descrição da aparência, os intelectuais formam um pensamento que, abstrato, ambíguo e parcial, sustenta a ordem instituída. A direção intelectual e política das massas torna-se fundamental na medida em que se consolida a hegemonia e se atua para conservar o instituído. Já na Revolução Francesa um exército invisível de livros asfaltou o caminho e preparou os homens e a sociedade para a revolução (GRAMSCI, 1978).

13 Se pensarmos no Reino das Duas Sicílias e na riqueza desenvolvida naquele longo período no Sul da península, a unificação conduzida pela burguesia do Norte foi desastrosa para essa região.

14 Esse tema foi por nós abordado no livro: Hegemonia e Cultura - Gramsci, publicado pela Editora da UFPR e tendo, em 2007, a sua terceira edição. 
Nesse contexto, a atuação dos intelectuais é fundamental e Gramsci acentua esta função no âmbito da democracia burguesa ao fazer a crítica aos teóricos das elites: Gaetano Mosca, Vilfredo Pareto e Robert Michels. No questionamento rigoroso dessas teorias do poder Gramsci explicita as características da democracia burguesa e a função dos intelectuais na formação do modo de pensar das massas.

Trata-se de mostrar que a teoria das elites concebe a política de modo restrito, a partir da afirmação de lideranças políticas que se legitimam pelo mérito e por sua origem de formação, a partir dos quais se atribuem o direito de dirigir e comandar as massas populares que, por sua condição histórica e social não se encontram aptas a governar ${ }^{15}$.

Essa postura elitista consolida-se na medida em que a estrutura da democracia burguesa, com sua forma de representação parlamentar e os mecanismos de absorção do transformismo, possibilita aos grupos dirigentes distanciarem-se das massas; completa-se com a ideia de chefe carismático de Robert Michels, cujo conceito de carisma Gramsci entende como problemático, incoerente e nebuloso para as massas que buscam um caminho de organização política, porque se nutre de sentimentos dependentes e elementares; um partido político de massa precisaria ser organizado não em torno de características individuais de seus lideres, mas "com base em uma concepção de mundo unitária” e expressiva de uma classe historicamente progressiva (Q. 2, p. 233).

O confronto de Gramsci com a teoria das elites esclarece conceitos fundamentais para o processo de organização política dos grupos subalternos, como a noção de democracia burguesa e seus limites na estrutura parlamentar, os conceitos de partido político e transformismo, enquanto mecanismos de cooptação dos intelectuais orgânicos formados nos movimentos de resistência dos trabalhadores que, na medida de sua fragilidade teórica e de sua assimilação ao discurso hegemônico, perdem suas lideranças para as classes dominantes. Uma das bases de sustentação do elitismo é o individualismo difuso no senso comum, além do discurso da meritocracia e do sistema jurídico que garante formalmente direitos de participação política sem colocar em questão a desigualdade de classes.

Para Gramsci, cabe salientar dois aspectos do conceito de elite de Pareto, importantes para se compreender a hegemonia burguesa: a teoria

15 Esse tema abordamos no V Colóquio Marx e Engels, realizado em Campinas em 2007. Anais publicados em http://www.unicamp.br/cemarx/anais_v_coloquio_arquivos/arquivos/comunicacoes/gt1/sessao4/ Anita_Schlesener.pdf. 
das elites é uma "tentativa de interpretar o fenômeno histórico dos intelectuais e de sua função na vida estatal e social” (Q. 8, p. 956); explicita ainda o processo de cooptação das lideranças trabalhadoras, que são absorvidas na medida em que "um grupo subalterno que não conquistou ainda consciência de sua força e de suas possibilidades", não tem clareza de suas funções históricas porque possui uma compreensão fragmentária e episódica de suas lutas e não consegue sair de uma fase inicial de organização (Q. 13, p. 1589).

Permanecer no âmbito de uma concepção de mundo econômicocorporativa fragiliza o movimento e abre a possibilidade de migração dos dirigentes no fenômeno do transformismo. Do mesmo modo que a teoria das elites de Pareto, o conceito de "classe política", de Mosca, refere-se à formação dos intelectuais da classe dominante, porém de modo indefinido (Q. 12, p. 1513). Já ao conceito de líder carismático de Michels, Gramsci contrapõe a noção de partido político salientando as diferenças entre a prática política dominante e os objetivos do materialismo histórico (Q. 7, p. 864 e Q. 13, p. 1565).

A luta revolucionária do proletariado implica compreender e superar o projeto político e cultural dos dominantes para, com a formação de seus intelectuais e sua organização política, elaborar a sua identidade de classe e o seu projeto social e político alternativo. No contexto do qual parte Gramsci, significa explicitar e criticar o projeto liberal e seus desdobramentos na formação do senso comum. A questão do conhecimento e do domínio da linguagem é fundamental visto que as palavras, na sua ambiguidade e eficácia ideológica, revelam ou escondem as possibilidades históricas de transformação, na medida do seu poder de naturalizarem-se acentuando sua força mistificadora.

A questão dos intelectuais no contexto das relações de hegemonia parte da constatação de que

cada grupo social, nascendo no terreno originário de uma função social no mundo da produção econômica, cria para si, organicamente, uma ou mais camadas de intelectuais que lhe dão homogeneidade e consciência da própria função, não apenas no campo econômico, mas também no social e no político (Q. 12, p. 1513).

No caso da Itália, as políticas historicamente centralizadas e paternalistas desde o processo de unificação, bem como a ação da Igreja católica, criaram as condições de consolidação da separação intelectuais-povo, já existente no período medieval. O liberalismo limitou-se a incentivar uma cultura de elite de cujo grupo de intelectuais faz parte Benedetto Croce; seu 
trabalho persistente de formação do senso comum por meio dos jornais e de uma produção teórica constante de releitura histórica amplamente conhecida na Itália. No curso da história a separação intelectuais-povo deixou um vazio no âmbito da literatura, a partir da ausência de interesse ou preocupação, por parte dos intelectuais, pelos problemas e sentimentos populares, fator que deixou o mercado editorial italiano livre para a influência de grupos intelectuais estrangeiros, principalmente a França (GRAMSCI, 1978) ${ }^{16}$.

No confronto das forças sociais em presença, as classes populares saem sempre debilitadas, com muitas dificuldades em sua organização política, visto que seus intelectuais cedo ou tarde migram para as trincheiras opostas. Ao assimilar pressupostos teóricos do liberalismo, os dirigentes dos grupos subalternos não conseguem superar a fase econômico-corporativa e caem no erro teórico de tomar o parcial pelo abrangente, caindo no que Dias (2012, p. 85) denomina de "capitulação ideológica”.

O nexo entre ideologias livre-cambistas e sindicalismo teórico é especialmente evidente na Itália, onde é conhecida a admiração por Pareto por parte de sindicalistas [...]. mas i significado dessas duas tendências, porém, é muito diverso: a primeira é própria de um grupo social dominante e dirigente; a segunda, de um grupo ainda subalterno, que ainda não adquiriu consciência de suas forças e de suas possibilidades e modos de desenvolvimento e, por isso, não sabe sair da fase de primitivismo (Q. 13, p. 1589).

Esse movimento de migração dos dirigentes dos grupos subalternos para os grupos dominantes Gramsci denomina de transformismo, conceito que significa, em linhas gerais, um processo de cooptação por parte das elites dominantes dos potenciais dirigentes das classes subalternas, aqueles que se destacam pela sua capacidade de organizar e dirigir um movimento. A impotência das massas em reagir a esse movimento migratório se encontra na dificuldade em elaborar um pensamento autônomo e abrangente, que permita entender o conjunto de relações que formam a estrutura da sociedade moderna.

16 Alguns fragmentos abordam a questão da ausência de uma literatura nacional-popular: a literatura popular desperta o interesse do público, não tanto pelo escritor, mas pelo personagem. Mas é a atitude do escritor, conforme Gramsci, que é essencial para o conteúdo; a "atitude é que determina o mundo cultural de uma geração e de uma época". Por exemplo: em Manzoni e em Verga, "não são os 'personagens populares' o elemento determinante, mas a atitude dos dois escritores em face de tais personagens. [...] Em Manzini, há um paternalismo católico, uma ironia subentendida, indício de ausência de profundo amor instintivo por aqueles personagens", sentimento ditado pela moral católica. "Em Verga, há uma atitude de fria impassibilidade científica e fotográfica, ditada pelos cânones do verismo, aplicado mais racionalmente do que por Zola” (Q. 8, p. 943). 
A capitulação ideológica de seus líderes deixa os subalternos a mercê das contradições e da fragmentação, sem condições de dar forma concreta a suas reivindicações; mesmo assim, aqui e ali recomeçam os movimentos de resistência e de busca de projetos alternativos, que implicam tanto a organização política quanto o trabalho educativo e formativo de releitura da história. Na senda de Marx, que escrevia sobre os mecanismos da burguesia na luta de classes, Gramsci dizia, a proposito dos Conselhos de Fábrica, que a sociedade capitalista nasceu da luta contra o feudalismo e, depois de consolidada, precisou criar instrumentos de enfrentamento das massas operárias urbanas que, aliadas ao campesinato, pretendiam uma nova ordem social. Para tanto, criou todos os mecanismos ideológicos imagináveis para educar e disciplinar essa massa conformando-a aos objetivos de seu projeto econômico e político; quando estes instrumentos não funcionavam, recorria-se ao uso da força. Na situação italiana de 1920, Gramsci acentuava que a fase da luta de classes se encontrava diante de duas alternativas: ou a conquista do poder político pelo proletariado revolucionário ou uma violenta reação da parte dos proprietários e do poder instituído:

Nenhuma violência será poupada para subjugar o proletariado industrial e agrícola a um trabalho servil: procurar-se-á despedaçar inexoravelmente os organismos de luta política da classe operaria (Partido Socialista) e incorporar os organismos de resistência econômica (sindicatos e cooperativas) nas engrenagens do Estado burguês (GRAMSCI, 1975, p. 117) ${ }^{17}$.

O que se depreende dessa leitura é que a questão da hegemonia vai muito além de um processo de governança por meio do consenso como, em geral, se entende. Hegemonia significa luta de classes, luta que se renova com outros nuances no movimento de colocação e superação das contradições econômicas, sociais e políticas que formam, na sua articulação e entrelaçamento, a estrutura da sociedade. Assim como as classes populares procuram criar formas de resistência, a classe dominante cria mecanismos de absorção de dirigentes, de conformismo ao sistema vigente por meio da formação do senso comum, da crença na neutralidade do conhecimento e na existência de uma verdade eterna, naturalizando os fatos sociais e históricos.

17 Se tornou uma prática comum no curso da história do capitalismo: despedaçar os organismos de luta política e cooptar os dirigentes; para tanto, usa-se a força da polícia ou do exercito, não apenas no caso das ditaduras militares, mas no caso de greves que se transformam em mecanismos de resistência, haja visto o ocorrido com os professores e funcionários públicos no Estado do Paraná em 29 de abril de 2015. Do mesmo modo, as torturas cometidas durante a ditadura militar contra os jovens resistentes, estendese de outras maneiras nos cárceres superlotados com pequenos delinquentes, muitos ainda jovens, sem condições de acesso ao saber necessário para o mercado de trabalho. E os representantes da burguesia procuram criar novos mecanismos para diminuir a idade penal, sem considerar as condições econômicas e sociais que submetem grande parte dessa população carcerária. 
Nesse contexto, a questão dos intelectuais, assim como a da cultura ou a da literatura, é uma questão fundamentalmente de luta de classes, de projetos sociais opostos e contraditórios que se confrontam na disputa pela hegemonia. De modo que não se pode, de modo algum, fazer uma abordagem culturalista ou pós-moderna com o aporte teórico gramsciano, porque seu pensamento é profundamente dialético e revolucionário, voltado a reconhecer as contradições do movimento histórico e a evidenciar as relações que concretizam a luta de classes. Este aporte pode nos servir para entender as condições sociais e políticas do capitalismo do século XXI e, neste sentido, a atualidade de seu pensamento; mas sempre sem esquecer o contexto histórico e político no qual essas ideias foram geradas, sem esquecer igualmente a história da luta dos trabalhadores italianos por uma nova ordem social e política, o pano de fundo da revolução socialista.

Como acentua Mordenti (2007, p. 42), para Gramsci a revolução era um fato atual "(o que não significava iminente e menos ainda, inevitável), vale dizer, estava na ordem do dia da história”. E para exemplificar retoma uma leitura que Gramsci faz (de memória) de $O$ Capital, a fim de mostrar a atualidade de seu pensamento. A citação é do fragmento 33 do Caderno 10, na crítica à interpretação de Croce sobre a queda tendencial da taxa de lucro. Gramsci demonstra que, maldosamente ${ }^{18}$, Croce concentra-se no volume III sem citar ou relacionar o conteúdo desse volume com o primeiro volume do O Capital, onde se trata da mais-valia relativa; e Gramsci conclui: "pode-se imaginar quando a contradição atingirá um nó górdio, normalmente insolúvel, exigindo a intervenção de uma espada de Alexandre?” Isso poderá acontecer "quando toda a economia mundial se tornar capitalista e atingir um certo grau de desenvolvimento", ou seja, quando "o mundo capitalista tiver alcançado as suas colunas de Hércules"; cabe entender que a produção de "mais-valia relativa tem limites que são dados, por exemplo, do ponto de vista técnico, pela extensão e pela resistência elástica da matéria" e, socialmente, pela "quantidade suportável de desemprego em uma determinada sociedade”. De outro modo, "a contradição econômica

18 "Croce apresenta como objeção à teoria exposta no terceiro volume a parte que está contida no primeiro volume, ou seja, expõe como objeção à lei da queda tendencial da taxa de lucro a demonstração da existência de uma mais-valia relativa devida ao progresso técnico sem, contudo, referir-se uma única vez ao primeiro volume, como se a objeção tivesse saído do seu cérebro ou como se fosse algo do bom senso" (Q. 10, p. 1278). A crítica à leitura de Croce se aprofunda no parágrafo 36 do Caderno 10 (p. 1281-1282), onde Gramsci mostra como Croce faz uma análise parcial ao esquecer o trabalho socialmente necessário para a acumulação do capital, bem como os demais mecanismos aos quais os industriais recorrem para evitar a queda tendencial da taxa de lucro, tomando como exemplo o taylorismo e o fordismo. 
torna-se contradição política e se resolve politicamente por uma subversão da praxis" (Q. 10, p. 1279).

Para Mordenti (2007, p. 176) Gramsci certamente utiliza o conceito "subversão da praxis" no lugar de "revolução", uma palavra que não utiliza por motivo de censura carcerária. Os Cadernos 13, 15 e 25 colocam questões importantes que apontam nesta direção e que foram pouco abordadas no contexto das leituras de Gramsci no Brasil.

\section{A hegemonia e a luta de classes: a possibilidade de violência insurrecional}

Prestar atenção no presente, se se quer transformá-lo. Pessimismo da inteligência, otimismo da vontade (Q. 9, p. 1131).

O Caderno 13 traz o título: Notas sobre Maquiavel e consideramos um Caderno fundamental para se explicitar a questão da hegemonia. Nele encontramos a distinção entre grande e pequena política, o entrelaçamento entre teoria e prática na construção tanto das relações políticas quanto das análises teóricas dessas relações e, principalmente, um estudo sobre os vários níveis de relações de força na formação dos sistemas hegemônicos que culminam na organização dos Estados. Partindo de uma crítica ao modo desordenado de apresentar as observações empíricas em alguns tratados de ciência política, como o livro de Gaetano Mosca, Gramsci elenca os níveis de relações de força:

[...] a começar pela relação das forças internacionais (onde teriam lugar notas sobre o que é uma grande potência, sobre agrupamentos de Estados em sistemas hegemônicos e sobre os conceitos de independência e soberania no que se refere a pequenas e médias potências), passando para as relações sociais objetivas, isto é, ao grau de desenvolvimento das forças produtivas, às relações de força política e de partido (sistemas hegemônicos no interior do Estado) e às relações políticas imediatas (ou seja, potencialmente militares) (Q. 13, p. 1562).

No caso de entender a estrutura, as relações econômicas e sociais fundamentais precedem as relações internacionais, que se modificam na medida em que acontecem mudanças orgânicas na estrutura. E Gramsci segue explicitando o entrelaçamento entre as condições econômicas e sociais objetivas e as relações internacionais, acentuando as formas como as forças partidárias internas atuam e expressam as relações de subordinação de grupos nacionais aos interesses internacionais (Q. 13, p. 1562). 
Essa abordagem pode ser encontrada também no Caderno 10, em que Gramsci acentua que esse tema pode ser relacionado com "a abordagem moderna da teoria e da prática pedagógica segundo a qual a relação entre professor e aluno é uma relação ativa, de reciprocidade", devendo-se entender por pedagógico o conjunto de relações que perpassam a estrutura social, desde a relação dos indivíduos entre si, até as relações entre governantes e governados, dirigentes e dirigidos. "Toda relação de 'hegemonia' é necessariamente uma relação pedagógica”, que ocorre entre as diversas forças internas a uma nação quanto entre nações (Q. 10, p. 1331).

Essa questão é importante primeiro porque amplia a questão pedagógica para acentuar que a educação perpassa a estrutura social num processo de formação contínua que ocorre no cotidiano dos indivíduos e no conjunto de relações de força que constituem a organização da sociedade e as relações (econômicas, políticas e culturais) internacionais; segundo, porque acentua a dimensão política da educação em todos os âmbitos da sociedade ${ }^{19}$.

Cabe acentuar que as observações sobre a hegemonia e o pedagógico do Caderno 10 vêm precedidas pela questão da linguagem a partir de uma crítica ao pragmatismo de Vailati. Gramsci acentua que, com relação ao pragmatismo, como outras filosofias, não existe uma referência "seja à totalidade do sistema ou ao seu núcleo essencial”. E completa dizendo que toda linguagem é também cultura e filosofia, ou seja, história e política. A "cultura, nos seus vários graus, unifica uma maior ou menor quantidade de indivíduos em estratos numerosos" que se entendem entre si em graus diversos, diferenças que se apresentam na linguagem (Q.10, p. 1330).

O que se depreende desse conjunto é que o "modo de vida materializa a passagem das macroestruturas (relações capital-trabalho na sua forma mais abstrata) às micro relações (o cotidiano das classes)" (DIAS, 2012, p. 51). O nosso modo de ser e de nos expressar cotidianamente traduz o conjunto de relações econômicas, sociais, políticas e culturais das quais fazemos parte e, na medida em que não temos clareza dessas relações estruturais, vivemos as contradições dessa realidade e nos conformamos à dominação. A divisão social do trabalho e a consequente divisão governantes-governados, dirigentes-dirigidos, fundamenta e perpassa as relações vividas na família, na escola, na empresa, na formação de grupos sociais e toma expressão no

19 Essa questão é importante na medida em que, na fase da política neoliberal e do desmantelamento da estrutura da escola pública em todos os países nos quais essa política se aplica, a responsabilidade de educar é atribuída unicamente ao professor, responsabilizado pelo fracasso escolar. 
nosso modo de pensar e de conceber o mundo. Nisso consistem as relações de hegemonia e também as relações pedagógicas que sustentam o nosso cotidiano.

A questão que se coloca é: como subverter a praxis? Primeiro, tendo clareza que o que fundamenta a hegemonia é a luta de classes; segundo, que a hegemonia se produz pela articulação entre dominação e formação do consentimento, o que supõe ter o controle da linguagem (e do conhecimento) e da ideologia como prática de poder; terceiro, ter clareza que, nesse contexto, os subalternos, ou seja, tanto as classes trabalhadoras quanto os que se encontram à margem da história, são reduzidos ao conformismo social, porque são excluídos do conhecimento efetivo.

Cabe acentuar, como bem lembra Marcuse (1999, p. 79) a propósito das rebeliões de 1968 retomando Marx, as "revoluções são sempre tão violentas quanto a violência à qual se contrapõem”. E Gramsci acentuava essa característica já em 1917, no artigo Três princípios, três ordens: a multidão teme mudanças radicais, porque forma a "imagem de uma coisa de violentamente lacerada; não vê a ordem nova possível, melhor organizada e mais vital" que pode ser construída (GRAMSCI, 1975, p. 73-74). Em geral, no senso comum, entende-se violência a luta aberta, o enfrentamento com armas e não a violência cotidiana presente na fome, na miséria, na exploração do trabalho. E, na senda dos conceitos abstratos, espera-se a paz e a harmonia, como se elas fossem possíveis numa sociedade profundamente dividida e desigual.

Desta perspectiva, a questão da hegemonia precisa ser reformulada: sua base é a luta de classes, mas ela assume outras dimensões na medida em que a hegemonia cria novos mecanismos de dominação pela via da formação e consolidação de um consenso passivo. Torna-se necessário identificar a ideologia dominante e conhecer os códigos de leitura, porque a linguagem é política e metafórica. Existem palavras que, por serem abstratas ou naturalizadas no contexto da ideologia dominante, se apresentam como engodos; exemplos existem muitos: ordem, liberdade, igualdade, emancipação humana. O erro não se encontra nas palavras, mas na não identificação da realidade que elas escondem por meio da ideologia que elas veiculam.

A eficácia política da ideologia veiculada por meio dessas palavras se traduz em obnubilar seu significado histórico e efetuar uma aprendizagem desses conceitos como se fossem naturais. Quando um conceito se naturaliza, perde-se a compreensão de sua historicidade e ele se congela, se fortalece 
e adquire uma força de conservação. Assimilar desta maneira os conceitos implica tomá-los como se fossem verdades absolutas. O passo seguinte é considerar como errado e descartável tudo o que se opõe a estes significados congelados. Pensar a ordem como natural leva a entender que ela não pode ser mudada e que tudo o que a ameaça se apresenta como um perigo. A "naturalidade" estende-se a outros conceitos, que dificultam a aceitação do diferente, do novo, do contraditório. O pensamento se imobiliza, não reconhece outra perspectiva, não dialoga e se congela em dogmas.

Nesse contexto, temos que considerar o que Gramsci chama de “dupla perspectiva" na ação política e na vida estatal: trata-se da "natureza dúplice do Centauro maquiavélico, ferina e humana, da força e do consenso, da autoridade e da hegemonia, da violência e da civilidade, do momento individual e do universal”, que implica a agitação e a propaganda, etc. "Alguns reduziram a teoria da 'dupla perspectiva' a algo de mesquinho e de banal, a nada mais que a duas formas de 'imediaticidade' que se sucedem mecanicamente no tempo", esquecendo a complexidade e a dialeticidade dessa articulação (Q. 13, p. 1576). Em outras palavras, reduz-se a hegemonia ao consenso enquanto acordo entre partes, a uma simples adequação de interesses entre partes iguais, omitindo completamente que, na sociedade capitalista, a igualdade é um mito.

A metáfora do Centauro nos permite entender a hegemonia enquanto confronto, relações de forças, submissão do mais fraco, mistificação da realidade a partir de um discurso parcial apresentado como universal. Como acentua Dias (2014, p. 25), a mistificação se apresenta na construção de consensos num contexto no qual o "embate de projetos é apresentado como um choque entre a verdade (dos dominantes) e o erro (dos antagonistas), ou mesmo como uma guerra entre o bem e o mal". As "ideologias dos dominantes nunca são apresentadas como ideologias e sim como projetos" enquanto qualquer pensamento crítico é apresentado como ideológico e, dos subalternos, não se reconhece projeto algum.

Nesse contexto, a hegemonia se traduz em um poder legítimo, porque é reconhecido pela maioria como um movimento no qual o consenso substitui a força explícita e diminui a sua necessidade; mas sem se analisar o modo como se consolida esse consenso, não se compreende a fundo as verdadeiras implicações da hegemonia no contexto do capitalismo. $\mathrm{O}$ domínio desdobra-se na direção, reforça-se por meio dela, amplia-se e se difunde no modo de pensar, na medida em que se ampliam e se tornam cada vez mais sofisticados os mecanismos de dominação ideológica que 
alimentam o consenso político na sua ação permanente e reiterada de persuasão e consolidação do senso comum. Como acentua Burgio (2014, p. 239), os Cadernos nos apresentam "o estudo das relações hegemônicas" como o "lugar privilegiado de análise do caráter ambivalente da relação política no “mundo moderno'[...]”. Na senda aberta cabe analisar a questão das relações de força que, embora extremamente desiguais, tornam-se a via para construir a insurreição, pano de fundo das reflexões de Gramsci, que não abriu mão de suas expectativas revolucionárias, mesmo que a longo prazo e no curso de gerações.

Para explicitar a correlação de forças, retomamos o parágrafo 17 do Caderno 13 (p. 1579), no qual Gramsci parte dos dois princípios elencados por Marx no Prefácio à Crítica da Economia Política de 1859 e reescritos da seguinte forma: 1) "nenhuma sociedade se coloca tarefas para cuja solução ainda não existam as condições necessárias e suficientes"; [...] 2) que "nenhuma sociedade se dissolve e pode ser substituída antes que se tenham desenvolvido todas as formas de vida implícitas em suas relações”. Esses princípios são fundamentais para identificar o movimento estrutural ou orgânico e suas contradições, bem como as relações de força que se confrontam e interagem reciprocamente na construção da hegemonia. Esses princípios servem como ponto de partida para explicitar o movimento contraditório no qual as relações de produção e as forças produtivas se objetivam e a necessidade de compreender corretamente esse movimento a fim de construir as condições políticas e ideológicas de sua superação. Gramsci cita como exemplo os acontecimentos da Revolução Francesa a fim de evidenciar suas contradições internas, acentuando que o processo iniciou-se em 1789 com a derrota do Antigo Regime e se consolidou em 1871, com a derrota da nova classe emergente ocorrida na Comuna de Paris. Acentua ainda os desacordos entre os historiadores em reconhecer o momento em que a revolução se completa e como a vida política se equilibra na hegemonia burguesa (Q. 13, p. 1581).

A questão metodológica é reconhecer o movimento orgânico, distinguir os fatos de conjuntura e estabelecer sua relação com as articulações estruturais, identificando os momentos de crise, de progresso ou de refluxo do movimento. A "relação dialética entre as duas ordens de movimento (conjuntural e estrutural) e, portanto, de pesquisa, dificilmente são estabelecidas de modo correto", o que se traduz não apenas em erro historiográfico, mas principalmente um erro de graves consequências para a vida política (Q. 13, p. 1580). Desse modo, Gramsci supera a oposição estrutura-superestrutura 
e suas implicações deterministas ou idealistas com a articulação dialética entre econômico-social, político-ideológico a ser identificada no movimento orgânico e histórico.

Colocar corretamente a questão das relações de forças e identificar a sua articulação dialética permite explicitar a questão da hegemonia para além de sua interpretação parcial e liberal na redução do consenso à ideia de acordo entre iguais. Essa posição muitas vezes se apresenta no próprio movimento sindical, cuja política reduz o movimento aos limites do econômico corporativo, difícil de superar sem da dimensão das contradições em presença ${ }^{20}$. Entender o movimento contraditório por meio do qual ocorre o embate entre as forças sociais e os caminhos de resistência que as classes subalternas procuram criar na luta pela hegemonia é fundamental para uma transformação.

O erro de interpretação que se encontra na base da formulação liberal e mesmo sindical é a separação entre sociedade política e sociedade civil, que transforma o Estado em uma entidade abstrata e acima das diferenças sociais, possibilitando entender a luta pela hegemonia como algo a ser efetuado primeiro na sociedade civil. As possibilidades de cooptação dos dirigentes, de absorção de algumas demandas sociais por reformas e políticas compensatórias, possibilitam dissolver os movimentos de resistência pelo mecanismo que Gramsci denomina transformismo. Com esses mecanismos, aliados ao poder de formação ideológica do consentimento passivo, os grupos subalternos são absorvidos e não conseguem superar os limites da fase econômico-corporativa.

A partir desse contexto, as condições de realizar o que Gramsci denomina "subversão da praxis" tornam-se muito difíceis. A tarefa dos intelectuais continua a ser a de "combater as ideologias modernas nas suas formas mais refinadas" e "absorver todas as forças, tanto 'quantitativa' quanto 'qualitativamente', a fim de criar uma nova concepção de mundo capaz de alimentar um novo projeto social e político" (Q. 4, p. 422). Porque a nova dimensão da luta de classes é ideológica e exige apropriar-se de uma perspectiva crítica e

20 Interessante acentuar a crítica de Gramsci ao sindicalismo teórico de sua época, mostrando que, nos limites do pensamento liberal, essa forma de sindicalismo permanece nos limites do econômico-corporativo e, na medida em que representa um grupo subalterno, o impede, por meio de sua política, de se tornar dominante. No "caso da independência e autonomia do grupo subalterno" que esta forma de sindicato representa "são sacrificadas à hegemonia intelectual do grupo dominante". "Exclui-se a transformação do grupo dominado em dominante, ou porque o problema sequer é formulado [...], ou porque é apresentado de modos incongruentes e ineficientes (tendências social-democráticas em geral), ou ainda porque se afirma o salto imediato do regime dos grupos àquele da perfeita igualdade e da economia sindical" ( $Q$ 13, p. 1590-1591). 
abrangente a fim de enfrentar a luta pela hegemonia. Isso significa, no campo do conhecimento, desmistificar os conceitos naturalizados e a pretensão de neutralidade, recuperar a historicidade concreta da vida, identificar as contradições para superá-las, entender que a luta de classes acontece no cotidiano, no modo de vida e de pensar. Trata-se de compreender que, na sociedade, nada é natural, tudo é histórico.

Gramsci, na solidão do cárcere e a partir da análise histórica da Revolução Francesa e do Risorgimento, material histórico concreto que tinha como referência, acentua a importância política para os grupos subalternos de um pensamento próprio e articulado, garantia de clareza das relações de força e da possibilidade de transformação. E por meio dessas análises reflete sobre as possibilidades de os grupos subalternos criarem as condições de resistência e de organização política. Tais condições se apresentam nos momentos de crise de hegemonia, não apenas como crise econômica, mas como crise política e ideológica da classe dirigente.

A crise orgânica, em virtude da própria estrutura do Estado e do ideário liberal que forma o senso comum, aparece como crise política, dos partidos e dos grupos que governam e que não conseguem "construir uma direção política permanente e de longo alcance” (Q. 15, p. 1807), mas esconde problemas de fundo, que podem aflorar no conjunto de relações de forças entre classes. A crise apresenta determinadas características ideológicas que precisam ser identificadas, por exemplo, lamenta-se a "onda de materialismo", que está "vinculada com o que se chama 'crise de autoridade'. Se a classe dominante perdeu o consenso, ou seja, não é mais 'dirigente', mas unicamente 'dominante'[...]”, isso "significa que as grandes massas se afastaram das ideologias tradicionais, não acreditam mais naquilo que acreditavam antes, etc.” (Q. 3, p. 311).

Se a crise se estende e o grupo governante não consegue se entender, por vários motivos, as massas até então passivas podem iniciar um movimento de organização. Os sindicatos desempenham uma função importante neste processo, "não o fenômeno sindical entendido no seu sentido elementar de associacionismo de todos os grupos sociais para qualquer fim”, mas um sindicalismo de nova formação que, pela sua atuação, pode iniciar o processo de organização política para "mudar a estrutura política da sociedade" (Q. 15, p. 1808).

A esse primeiro passo devem agregar-se outros, com a criação de novas instituições de organização política e de formação ideológica, capazes tanto 
de unir em torno de um projeto alternativo quanto de conquistar adesão dos intelectuais tradicionais. Trata-se de uma tarefa de longo prazo, com idas e vindas e que pode resultar na efetivação de um projeto alternativo, ou seja, Gramsci confia na revolução e explicita as suas possibilidades, embora ressaltando as dificuldades de trilhar este caminho.

No contexto do capitalismo a luta pela hegemonia se torna uma luta ideológica, algo que, segundo Edelman (2016, p. 77) Engels já acentuava: na "luta ideológica, há um conteúdo explicito e um conteúdo latente. O conteúdo explicito é a ideologia burguesa tomada literalmente, voltada contra ela própria; o conteúdo latente é a abolição das classes”. Explicitar o conteúdo latente é a tarefa tanto dos movimentos sociais no caminho de sua organização política quanto de uma educação escolar que se pretenda crítica e ensinar a ler a realidade.

\section{Subversão da praxis $X$ revolução passiva: a atualidade de Gramsci}

Tarefa da infância: integrar o novo mundo ao espaço simbólico. A criança é capaz de fazer algo que o adulto não consegue: rememorar o novo (BENJAMIN, 2009, K 1a, 3, p. 435).

Movimentos insurrecionais e as mais variadas formas de resistência cultural e política sempre existiram ao longo da história da sociedade capitalista. Marx acentuava, em O 18 Brumário de Luís Bonaparte, a diferença principal entre as revoluções burguesas e a possível revolução proletária: a primeira, depois de um período de ascensão se consolida e se estabiliza; a segunda, passa por derrotas que exigem recomeçar tudo novamente muitas vezes do zero. São revoluções que precisam fazer a crítica de si próprias:

[...] interrompem continuamente seu curso, voltam ao que parecia resolvido para recomeçá-lo outra vez, escarnecem com impiedosa consciência as deficiências, fraquezas e misérias de seus primeiros esforços, parecem derrubar seu adversário apenas para que este possa retirar da terra novas forças e erguer-se novamente, agigantado, diante delas, recuam constantemente ante a magnitude infinita de seus próprios objetivos até que se cria uma situação que torna impossível qualquer retrocesso e na qual as próprias condições gritam: Hic Rhodus, hic salta! Aqui está Rodes, salta aqui! (MARX, 1977, p. 21).

Para explicitar as bases dessa luta entre David e Golias que, no curso do século XX, tomou novas dimensões, precisamos partir de duas observações de Gramsci sobre critérios metodológicos: 1) a "história dos grupos sociais subalternos é necessariamente desagregada e episódica” e em sua 
atividade histórica "existe a tendência para a unificação, ainda que de forma provisória, mas esta tendência é sempre rompida pela iniciativa dos grupos dominantes" (Q. 25, p. 2283); 2) a "unidade histórica das classes dirigentes acontece no Estado e sua história é essencialmente a história dos Estados e dos grupos de Estados". Porém, não se trata de uma "unidade puramente jurídica e política”, mas fundamentalmente de uma unidade cujo "caráter concreto é o resultado das relações orgânicas entre Estado, ou sociedade política e 'sociedade civil'[...]" (Q. 25, p. 2287-2288). Ou seja, a unidade histórica e orgânica que se expressa no Estado é vivida de modo rigoroso apenas pelas classes dominantes e, por isso, faz-se necessário fazer a crítica da historiografia. As classes subalternas não possuem uma unidade histórica, ou seja, conforme Gramsci, vivem à margem da história enquanto subordinadas ao modo de ser e de pensar hegemônicos, sendo necessário e imprescindível explicitar a sua história.

Essa subordinação assume formas variadas que passam pela aceitação dos fatos como naturais, pela formação do imaginário social tendo a ideologia como prática de poder e por outros mecanismos de subordinação que Gramsci explicita no conceito de revolução passiva que perpassam os cadernos na análise dos movimentos revolucionários europeus e italianos, material empírico concreto a partir do qual Gramsci redefine e amplia este conceito, apresentado por Vincenzo Cuoco na obra Saggio storico sulla rivoluzione di Napoli. Trata-se de explicitar as formas conservadoras e reformistas de construção dos Estados modernos, no caso, o processo de unificação italiano, ou: como, "sob um determinado invólucro político se modificam necessariamente as relações sociais fundamentais e novas forças políticas efetivas surgem e se desenvolvem" influenciando indiretamente e de modo quase imperceptível "as forças oficiais, que se modificam a si próprias quase sem perceberem” (Q. 15, p. 1818-1819).

Embora as forças em presença interajam entre si, como vimos, as classes subalternas não possuem ainda uma unidade e uma força organizativa que lhes permita tomarem a frente desse processo. Exemplo foram os movimentos de 1848-1849 na Itália e, posteriormente, pela atuação de Garibaldi e Mazzini no movimento de unificação. As massas populares são atuantes e tentam criar movimentos insurrecionais, mas não possuem ainda força organizativa e seus líderes acabam sendo cooptados, fortalecendo os grupos dominantes. No caso da unificação italiana, o que caracteriza a revolução passiva se resume no fato que a força dirigente vinha do Estado piemontês, que se fazia “[...]'dirigente' do grupo que deveria ser dirigente, 
colocando à sua disposição um exército e uma força político-diplomática" (Q. 15, p. 1823).

A unidade das classes subalternas não pode ocorrer enquanto essas classes não conquistarem o Estado, de modo que sua experiência se caracteriza pela fragmentariedade e heterogeneidade. Os "grupos subalternos sofrem sempre a iniciativa dos grupos dominantes, mesmo quando se rebelam e insurgem: somente a vitória 'permanente' rompe, e não imediatamente, a subordinação”. Na realidade, mesmo em momentos de vitória, os grupos subalternos permanecem em "estado de defesa, em alerta”. Nesta medida, "qualquer traço de iniciativa autônoma da parte dos grupos subalternos deveria ser de valor inestimável para o historiador integral” (vale dizer, materialista) (Q 25, p. 2283-4).

A importância política de se escrever a história das classes subalternas se encontra em que este é um dos mecanismos de formação de uma identidade de classe, necessária para a luta por um novo projeto social e político. Os próprios grupos subalternos têm dificuldade em fazer este inventário e os intelectuais que representam os grupos dominantes lêm esses acontecimentos da perspectiva dominante; como exemplo, a história de David Lazzaretti: ${ }^{21}$ "em lugar de se estudar a origem de um acontecimento coletivo e as razões de sua difusão, do seu ser coletivo", isola-se o protagonista central e se faz a sua biografia patológica; "para uma elite social, os elementos dos grupos subalternos têm sempre alguma coisa de bárbaro ou patológico”, ou seja, de incompreensível. Essas ideias acabam formando a opinião pública com explicações restritivas, folclóricas, patológicas, o que se pode identificar nas narrativas sobre os Briganti (Q. 25, p. 2279).

Essa é a perspectiva de leitura da existência e das lutas dos Briganti, no Sul da Itália, por parte das elites dirigentes: os Briganti são entendidos como bandidos e não como líderes da resistência camponesa. Assim, Lazzaretti "foi morto aclamando a república", quem sabe pela razão de que, no movimento que liderava, a "tendência republicana se misturava

21 David Lazzaretti foi um líder de movimento popular em forma de seita religiosa no século XIX, na Toscana; manifestou-se em favor da Comuna de Paris e defendia a instauração de uma república. A força do movimento popular por ele liderado mobilizou o exercito em sua caçada, sendo fuzilado em 1878 . "Os homens políticos não se ocupam do fato que o assassinato de Lazzaretti foi de uma crueldade feroz e friamente premeditada (na realidade Lazzaretti foi fuzilado e não morto em combate: seria interessante conhecer a investigação reservada enviada pelo governo as autoridades); nem os republicanos se ocuparam (pesquisar e verificar) embora Lazzaretti tenha morrido exaltando a República (o caráter tendencialmente republicano do movimento, que poderia difundir-se entre os camponeses, deve ter contribuído para determinar a vontade do governo de exterminar o protagonista)" visto que a "tendência republicana era bizarramente misturada ao elemento religioso e profético" (Q. 25, p. 2280). Essa análise de Gramsci nos faz recordar Canudos e Contestado no Brasil. 
ao elemento religioso e profético", próprio da cultura popular camponesa. Mas, precisamente essa mistura "representa a característica principal do acontecimento, porque demonstra a sua popularidade e espontaneidade". Esse movimento "mostrou ao governo a tendência subversiva-popular-elementar que podia nascer entre os camponeses" (Q. 25, p. 2280).

A estratégia de desmobilização utilizada pela classe dominante é isolar o líder para cooptá-lo ou assassiná-lo e, em seguida, desmobilizar os que fazem parte do movimento. Quando as ações são centralizadas em indivíduos, a atenção do público é desviada do objetivo principal e o público “torna-se 'expectador' de uma luta de gladiadores” (Q. 8, p. 982). A importância de uma história das classes subalternas consiste em que história e política se articulam e se identificam: "todo historiador é também um político" e "toda história é história contemporânea" (Q. 10, p. 1842). Existem, sempre, elementos de resistência na vida e nas ações das classes populares, os quais precisam ser identificados e incentivados como base de uma consciência de classe.

Para unificar um movimento a fim de encaminhar a luta por uma nova ordem social e política é fundamental que se criem organizações que viabilizem o processo de unificação. Na sua juventude militante, Gramsci participou da organização dos Conselhos de Fábrica e não se cansou de formar grupos de estudo e de formação, participando ativamente da elaboração e publicação de jornais destinados à formação dos trabalhadores. Elemento articulador importante é o Partido, que tem a função de unificar as tendências em presença e criar as condições de unificação dos grupos subalternos, procurando explicitar as condições de suas lutas e atuando para que saiam de sua situação de espontaneidade para se tornarem também dirigentes, porque Gramsci questiona a existência de uma vanguarda acima das massas ${ }^{22}$.

Nesse contexto, escrever a história dos grupos subalternos implica seguir determinados critérios metodológicos, que Gramsci descreve da seguinte forma:

É necessário estudar: 1) a formação objetiva dos grupos sociais subalternos, por meio do desenvolvimento e das transformações que se verificam no mundo da produção econômica, a sua difusão quantitativa e a sua origem a partir de grupos sociais preexistentes, dos quais conservam, por um certo tempo, a mentalidade, a ideologia e os objetivos; 2) sua adesão, de

22 Esse tema foi por nós tratado no livro: SCHLESENER, A. H. Antonio Gramsci e a política italiana pensamento, polêmicas, interpretação. Curitiba: UTP, 2005. 
modo ativo ou passivo, às formações políticas dominantes, as tentativas de influir sobre os programas dessas formações para impor reivindicações próprias e as consequências que tem tais tentativas na determinação dos processos de decomposição e de renovação ou de nova formação; 3) o nascimento de novos partidos dos grupos dominantes para manter o consenso e o controle dos grupos subalternos; 4) as próprias formações dos grupos subalternos para reivindicações de caráter restrito e parcial; 5) as novas formações que afirmam a autonomia dos grupos subalternos, mas ainda nos velhos quadros; 6) as formações que afirmam a autonomia integral, etc. (Q. 25, p. 2288).

Esse quadro esclarecendo critérios metodológicos de leitura visa a explicitar o movimento de organização política dos grupos subalternos no interior das relações de força e dos mecanismos de submissão que caracterizam a hegemonia dominante. Gramsci acentua que essa lista de encaminhamento de análise crítica pode ser ainda mais detalhada, com fases intermediárias e combinações dessas fases. Implica entender o conjunto de relações de força (ou os desdobramentos da luta de classes) no contexto da estrutura do modo de produção capitalista, bem como os mecanismos de cooptação e de submissão ideológica que caracterizam as relações de hegemonia na sociedade moderna.

O ordenamento no qual Gramsci elaborou esses critérios demonstra: primeiro, o desdobramento das contradições e a desigualdade de forças na luta entre dominantes e dominados para construir uma iniciativa autônoma da parte dos movimentos sociais e, segundo, que esta dificuldade demonstra que a desarticulação ocorre em função da própria condição de subalternidade. Isto acontece porque o Estado atua como organizador e educador para as classes dominantes, de modo que as classes subalternas, enquanto não se unificarem politicamente em um Estado, podem ser desarticuladas pelos mecanismos dominantes; ou seja, seus limites se colocam a partir de uma atuação que precisa ser construída dentro da ordem vigente e que, neste contexto, pode ser, a qualquer momento, cooptada e desarticulada. O historiador materialista deve evidenciar e justificar a linha de desenvolvimento em direção à autonomia integral desde as fases mais primitivas de resistência, evidenciando "cada manifestação do soreliano 'espirito de cisão'[...]”, ou seja, explicitando as contradições e o movimento de sua superação (Q. 25, p. 2288). A propósito do conceito soreliano "espírito de cisão" Gramsci escreve no Caderno 3:

$\mathrm{O}$ que se pode contrapor, da parte de uma classe inovadora, a este complexo formidável de trincheiras e fortificações da classe dominante? O 
espírito de cisão, ou seja, a progressiva conquista da consciência da própria personalidade histórica, espírito de cisão que deve tender a ampliar-se da classe protagonista para as classes potencialmente aliadas: tudo isto requer um complexo trabalho ideológico, [...] (Q. 3, p. 333).

O espirito de cisão implica, portanto, um intenso trabalho de organização política e preparação ideológica a fim de construir as bases de um movimento revolucionário contando com a aliança entre a classe inovadora e as demais classes subalternas. Essa tarefa, que é dos intelectuais, exige identificar, num determinado momento histórico, o processo de formação de uma vontade coletiva, decorrente da proposição de que "a sociedade não se põe problemas para cuja solução ainda não existam as premissas materiais". ${ }^{23}$ Implica explicitar como se formam as vontades coletivas e como estas se "propõem objetivos imediatos e mediatos concretos", direcionando a sua ação para um determinado fim. E Gramsci descreve as fases de estudo para explicitar "concretamente a formação de um movimento histórico coletivo" (Q. 8, p. 1057).

Essas condições precisam ser abordadas pelo partido das classes subalternas e por seus intelectuais orgânicos e o historiador deste processo precisa estar atento para a complexidade deste movimento, para as repercussões da atividade partidária e as forças internas ou tendências que tendem a assumir a direção, assim como o envolvimento efetivo das massas. Para os grupos subalternos, a importância de conhecer esse processo está em identificar-se como grupo ou classe social reconhecendo também a função do grupo dominante, a fim de criar as condições de enfrentamento político. Retomamos novamente aqui o caso de Garibaldi e Mazzini que, conforme Gramsci, não tinham clareza do conjunto de relações de força do qual participavam, enquanto Cavour tinha consciência clara tanto de sua função quanto da de Garibaldi e de Mazzini, de modo que o Partido Moderado, dirigido por Cavour, tinha o Partido da Ação "no seu bolso" (Q. 19, p. 2010).

A partir desses pressupostos, cabe acentuar a importância da educação enquanto formação política (partido), mas também a educação formal veiculada na escola, como elemento formador por meio da apropriação dos códigos de leitura e interpretação (do pensamento e da realidade). O domínio do conhecimento e da estrutura da linguagem se tornam fundamentais para elaborar a independência e a autonomia dos grupos subalternos,

23 Trata-se do Prefácio de 1859 da obra de Marx Para a Crítica da Economia Política, retomado por Gramsci como base de suas reflexões sobre a articulação entre economia, política e história, a fim de explicitar as condições concretas de organização do movimento revolucionário. 
principalmente num momento em que o conhecimento se tornou fundamental para a manutenção das estruturas de poder. O capital, para reproduzir-se, precisa de condições políticas que se mantém e se reproduzem por meio das formas de representação ideológica, o que dá uma significação política para a cultura e todas as formas de expressão artística, consolidando modos de ser e de pensar adequados ao movimento de apropriação que sustenta este sistema.

Todo processo educativo parte de uma perspectiva ideológica que não pode ser ignorada nem o conhecimento pode ser apresentado como neutro, assim como as relações sociais não podem ser apresentadas como naturais, porque deste modo se eternizam. Como acentua Broccoli (1977, p. 106), a "relação educativa, em sentido estrito, não é transmissão de cultura", mas sim o trabalho de formar a "consciência de historicidade dos indivíduos", ou seja, "inserir o homem na história e dar à criança a medida do contraditório da realidade e da dialética do desenvolvimento histórico", pressupostos importantes para subverter a praxis.

Desta perspectiva, a escola deveria ser completamente transformada em sua estrutura interna e em sua forma de ensino, algo muito difícil de ocorrer sendo que as políticas públicas emanam da ordem instituída visando conservá-la. A tentativa poderia se concretizar se articulada ao movimento de organização política dos grupos subalternos na luta pela hegemonia. Mas o que aconteceria se, nas "escolas primárias e secundárias as ciências naturais e físicas fossem ensinadas na base do relativismo de Einstein?” Antes disso, o senso comum precisa ser modificado e "se o ambiente é o educador, esse, por sua vez, deve ser educado” (Q. 10, p. 1425-1426) ${ }^{24}$.

Quando retoma a Tese 3 de Marx contra Feuerbach, Gramsci acentua que o ambiente é educador, entendendo que a educação é um processo que envolve a vida individual e social e que as relações de força nas quais se embatem os grupos sociais na luta pela hegemonia formam a base desse movimento que perpassa a vida de todos. Os grupos subalternos precisam da escola, mas também de órgãos independentes de formação política e cultural, a fim de elaborarem e defenderem um projeto social alternativo. A luta de classes, para sustentar a ordem econômica e social, passa pela formação do imaginário. Na medida em que a ideologia se transforma em

24 Para o nosso tempo e espaço a pergunta é outra: pode a escola responder aos interesses de formação das classes trabalhadoras numa sociedade profundamente desigual, na qual não se respeitam os mínimos direitos civis? Como renovar o ensino escolar num contexto de conformismo e de conservadorismo como este que grassa em nossa sociedade? Se o ambiente é educador, nosso desafio é hercúleo. 
instrumento de formação da opinião pública, de naturalização da historia e da cultura dominante, a formação de um modo de pensar autônomo das classes subalternas a partir de sua mobilização política torna-se fundamental.

Gramsci já anunciava nos Cadernos do Cárcere que a força da elite na manutenção do projeto hegemônico estava no não reconhecimento dos seus vínculos de classe. Entendendo-se como intelectuais "puros" e "qualificados" para as suas funções, "colocam-se a si próprios como autônomos e independentes do grupo social dominante" (Q. 12, p. 1515). Um movimento bem organizado e com clareza de objetivos pode conquistar para si esses intelectuais.

Por outro lado, as dificuldades que se apresentam são imensas, a partir dos mecanismos de cooptação política e ideológica dos quais as classes dominantes lançam mão para desmobilizar e calar as classes subalternas, no processo que Gramsci explicitou como revolução passiva. Esse movimento também denominado "revolução pelo alto" pode ocorrer de varias maneiras; ocorre quando, por exemplo, por intervenção do Estado, introduzem-se algumas mudanças que respondem a demandas sociais, mas não alteram o sistema de apropriação do lucro; ou ainda quando se efetuam alianças políticas que absorvem lideranças sociais importantes, como foi o caso do Risorgimento nas alianças entre Partido Moderado e Partido da Ação, denominado por transformismo a partir de suas referências históricas (Q. 19, p. 2010-2011).

O transformismo torna-se um mecanismo importante para o exercício da hegemonia e para a desmobilização dos movimentos sociais e insurrecionais. A dialética entre conservação e inovação, que se traduz no conceito de "revolução passiva" e que, na linguagem moderna pode ser denominado "reformismo" assumido como programa, é uma forma de exercer a hegemonia no contexto das democracias modernas, como mecanismo de desagregação dos movimentos sociais e de formação do consentimento passivo de grandes massas. Assim como o Risorgimento, também o fascismo se apresenta como "a 'forma' de revolução passiva própria do século XX, como o liberalismo o foi do século XIX” (Q. 8, p. 1089).

O ‘transformismo’ não é mais que a expressão parlamentar do fato que o Partido da Ação é molecularmente incorporado pelos moderados e as massas populares são decapitadas, não absorvidas no âmbito do novo Estado (Q. 19, p. 2042).

Por suas características, o transformismo deixa os grupos subalternos acéfalos por um longo período. Enquanto parte do processo de revolução 
passiva, o transformismo demonstra também a fragilidade dos partidos políticos que não conseguem se organizar em torno de um programa que expresse um projeto de sociedade e abrem a possibilidade para a realização de interesses individuais. A exemplo do Risorgimento, a "ausência de programa concreto, com tendência geral, é uma forma de 'mercenarismo' fluído", cujos componentes do partido acabam por alinhar-se com o mais forte, aquele que paga melhor, etc. (Q. 17, p. 1932).

Como acentua Dias (2012, p. 76), "construir a autonomia dos subalternos significa que estes devam ter homogeneidade não apenas no plano cultural", mas essa autonomia precisa ser a expressão de uma homogeneidade política, que supõe "romper - quebrar a estruturação da totalidade anterior". Isso se evidencia como uma batalha hegemônica, que envolve a articulação entre as instâncias econômica, política e ideológica, num trabalho efetivo dos "intelectuais, ou seja, das direções das classes em presença".

Gramsci tem como base de análise a Itália dos séculos XIX e início do XX, mas muitas de suas observações, pela sua clareza e precisão, podem ser remetidas para a atualidade, porque muitas dessas práticas continuam a ser correntes e são, inclusive, ampliadas. Na dimensão mais sofisticada que assume a luta de classes com o desenvolvimento e a apropriação do conhecimento tecnológico pelas classes dominantes, a questão da educação assume um lugar central no processo de emancipação política das classes subalternas. A importância de suas observações sobre movimentos insurrecionais e a possibilidade de subversão da praxis precisam ser acentuadas, principalmente para rebater as leituras mais conhecidas desse autor que o transformam, tanto na Itália quanto no Brasil, a mais um liberal insignificante.

Para subverter esta ordem é necessário trabalho e formação constante, educação permanente e continuada; no momento em que o despertar de atitudes conservadoras manifesta-se em todas as instâncias do social, a ponto de acadêmicos retomarem o discurso da neutralidade e acusarem os marxistas de "doutrinadores", na mais antiga tradição do positivismo, torna-se urgente despertar a consciência crítica dos grupos subalternos e a escola torna-se um espaço importante, na medida em que possibilita o acesso aos códigos da argumentação lógica e os instrumentos para a formulação de um pensamento claro e conciso. É preciso superar a noção de que a teoria é externa à prática e, principalmente, que é propriedade dos intelectuais burgueses, os que detém o conhecimento e a interpretação da realidade. A educação tem uma função fundamental de desvelar o que se 
esconde sob a aparência e a imediaticidade dos fatos, de mostrar o caráter de classe das ideias veiculadas como neutras porque a situação como apresentada pelos intelectuais em geral dificulta uma iniciativa autônoma da parte dos subalternos.

Neste contexto, explicitamos a seguir a questão da ideologia e seus vínculos com o exercício da hegemonia no âmbito da sociedade capitalista para, nos capítulos seguintes, abordarmos a questão da linguagem e da educação. 


\section{CAPÍTULO II}

\section{As dimensões DA IDEOLOGIA A PARTIR DA LEITURA GRAMSCIANA DE MARX}

O conteúdo da consciência encontra a sua origem e explicação no conteúdo da situação histórica (CHATELET, 1972, p. 231).

A questão da ideologia, temática que nos propomos abordar neste capítulo, nos desafia por sua amplitude e por ter sido tratada de diversas perspectivas ao longo das últimas décadas. A ela se vincula o título deste livro, que visa a mostrar a dimensão que a ideologia toma na vida dos homens na sociedade capitalista. Nos Cadernos do Cárcere, Gramsci se refere ao tema em 35 fragmentos ao longo de sua obra, iniciando com a origem do conceito na filosofia francesa, passando por uma reinterpretação da noção marxiana de ideologia para, enfim, explicitar o conceito na sua crítica aos pensamentos de Croce e de Bukharin. Entre os comentadores de Gramsci que abordam o assunto cabe citar o detalhado levantamento de Guido Liguori no léxico Le Parole di Gramsci, as pesquisas de Fabio Frosini em torno das continuidades e rupturas entre Marx e Gramsci, além de Giuseppe Prestipino no livro Tradire Gramsci e as publicações sobre a crítica, por um lado a Croce e por outro a Bukharin, que abordamos em outros escritos ${ }^{1}$. O recorte que nos propomos é a partir da abordagem e releitura gramsciana de Marx na definição de ideologia, a fim de explicitar sua relação com as noções de hegemonia e de linguagem, presentes nos Cadernos.

A formação do imaginário social e seus desdobramentos na política, explicitada por Marx ao longo de sua obra nas reflexões sobre ideologia, são o pressuposto do pensamento de Gramsci sobre a sua conceituação. Gramsci provavelmente não teve acesso à A Ideologia Alemã, publicada somente em $1932^{2}$, o que se depreende de sua leitura, concentrada nos textos que tinha em mãos.

1 A crítica a Bukharin se encontra em artigos apresentados em eventos (CEMARX e outros) e no livro (SCHLESENER, 2005); a leitura de Croce foi apresentada em artigos publicados na Revista Unisinos (São Leopoldo, 2007), Revista Reflexão (Campinas, 2006), Revista Sociedade e Estado (Brasília, 2007). 2 Conforme Guido Liguori, Gramsci talvez tenha tomado conhecimento da primeira parte do livro, Feuerbach, publicada em 1924, em russo e, posteriormente, em 1926, em alemão. Como não se encontram citações ou referências a esse texto nos escritos de Gramsci, ele "provavelmente não teve a disposição 
A Ideologia Alemã, como os próprios autores assinalam, tem a finalidade de um acerto de contas com a tradição filosófica a partir do debate com os herdeiros da filosofia hegeliana, no questionamento do pensamento de Feuerbach, Stirner e os irmãos Bauer, bem como no confronto indireto com o pensamento de Hegel, seguindo a senda aberta nos Manuscritos econômico-filosóficos, de Marx. Nos Manuscritos, porém, o acento se coloca nas noções de trabalho e de alienação, enquanto A ideologia Alemã explicita as condições históricas de produção e reprodução da consciência como parte do processo contraditório de produção e reprodução da vida material.

De uma perspectiva ampla, nos escritos de Marx, as raízes da noção de ideologia estão no modo como se instituem as relações de trabalho e as relações sociais, podendo ser encontrada desde os Manuscritos Econômicofilosóficos, até a sua obra mais completa no primeiro livro de O Capital, na explicitação da noção de mercadoria, na estrutura do modo de produção capitalista, a partir da análise do modo como se organizam as relações de trabalho e se produzem os valores (de uso e de troca).

Conforme Chatelet (2004, p. 108-109), Marx acentuou três características da ideologia ao longo de seu trabalho: a "ideologia é alienante, mistificante e reificante". Alienante porque "impõe ao homem uma visão da realidade que o torna estranho à sua verdadeira prática social”; mistificante ou mitificante porque ela produz "um certo número de mitos, destinados a polarizar a afetividade social"; e é ainda reificante porque "tende a fazer durar o estado de coisas dadas", ou seja, efetua uma operação de legitimação do dado, procurando "provar que o estado de coisas corresponde à natureza, à vocação, ao destino da humanidade e que este estado de coisas realiza plenamente o que sempre se desejou”. Estas dimensões da ideologia se ampliam na sociedade contemporânea a partir dos mecanismos tecnológicos inseridos tanto no modo de produção quanto na vida social, alterando a noção de verdade, enrijecendo o pensamento e obscurecendo a nossa visão de mundo.

Na perspectiva dos escritos se Marx, os Manuscritos Econômicofilosóficos trazem as primeiras intuições de Marx sobre a estrutura do modo de produção capitalista, a partir da análise das formas históricas de organização do trabalho e apropriação da força de trabalho por meio da consolidação da propriedade privada dos meios de produção; delineando essa estrutura, Marx explicita as várias formas de estranhamento/alienação

aquele que hoje estamos habituados a considerar o lugar de nascimento do moderno conceito de ideologia na sua conotação negativa marxiana e marxista" (FROSNI e LIGUORI, 2007, p. 132). 
que se produzem no contexto das relações de trabalho. Definido basicamente como um conjunto de ações pelas quais o produtor não se reconhece no produto do seu trabalho, o estranhamento estende-se a toda a vida individual e social: o homem torna-se estranho ao resultado de sua atividade, que lhe aparece como exterior, estranho ou distante da natureza, isolado dos outros e estranho a si próprio.

Esse movimento já traz implícita uma noção de ideologia, embora não se aborde ainda explicitamente o conceito: evidencia-se no processo de alienação uma inversão de valores que altera toda a significação da vida humana, na medida em que ocorre o movimento de objetivação valoriza-se o mundo das coisas e se desvaloriza o humano. Esse processo que ocorre no âmbito das relações econômicas e sociais, desdobra-se no modo de pensar e entender a realidade natural e o conjunto das relações sociais.

Tal como a propriedade privada é apenas a expressão sensível do fato de que o homem se torna objetivo para si e, ao mesmo tempo, se converte em um objeto estranho e inumano, do fato de que a exteriorização de sua vida é a alienação da sua vida e sua efetivação sua desefetivação, uma efetividade estranha, a superação positiva da propriedade privada, isto é, a apropriação sensível pelo homem e para o homem da essência e da vida humanas, do homem objetivo, das obras humanas, não deve ser concebida só no sentido do gozo imediato, exclusivo, no sentido da posse, do ter (MARX, 1974, p. 16-7).

A inversão aqui se apresenta na perda da dimensão global da vida humana, do homem como um ser que se produz e se conhece enquanto ser social, tanto que suas relações consigo mesmo, com o mundo das coisas e com os outros, "ver, ouvir, cheirar, saborear, sentir, pensar, observar, perceber, querer, atuar, amar - em resumo, todos os órgãos de sua individualidade", enquanto "órgãos que são imediatamente coletivos em sua forma" são, em seu comportamento objetivo, a apropriação desse movimento de produção do ser social. Porém, o que aparece imediatamente, enquanto efetivação imediata, é o ter individual, possessivo: a "propriedade privada tornou-nos tão estúpidos e unilaterais que um objeto só é nosso quando o temos, quando existe para nós como capital ou quando é imediatamente [...] utilizado por nós" (MARX, 1974, p. 17). Essa inversão se expressa ainda na maneira de entender a sensibilidade como individual e isolada, quando os sentidos, de modo geral, também se transformam com o movimento da história, pois a percepção sensível resulta de uma formação e inserção social.

Conforme a leitura de Ranieri (2000, p. 20-21), existe uma continuidade entre os Manuscritos de Paris e A Ideologia Alemã, de modo a se 
evidenciar, nos Manuscritos, a "exposição geral de um sistema" nascente que, em A Ideologia Alemã, toma forma mais acabada na crítica "às elaborações de Hegel e seus discípulos, além de estabelecer as bases orgânicas de uma teoria materialista da história". O elo se evidencia no modo como $A$ Ideologia Alemã retoma e amplia os quatro momentos de formação da alienação a partir da divisão do trabalho, da propriedade privada e das relações de troca no contexto da concentração dos meios de produção. Fundado na produção e consumo de mercadorias, o modo de produção capitalista tem como pressuposto a concentração dos meios de produção e a exploração da força de trabalho, a partir dos quais se desenrola o processo vital por meio do qual se constrói a sociedade e se elaboram as representações do social.

Os Manuscritos nos mostram que a representação de si e do mundo no contexto da filosofia hegeliana supõe a alienação, que o pensar abstrato é aquele que separa sujeito e objeto como elementos estanques que se opõe, o que se depreende da crítica ao pensamento de Hegel, a partir do qual o "homem alienado de si mesmo é também o pensador alienado de sua essência, isto é, da essência natural e humana”, cujos limites não consegue superar porque permanece no campo da abstração e da contemplação (MARX, 1974, p. 53), desvinculadas do contexto concreto do trabalho. Ao trabalhador, sem a dimensão social de sua produção, resta apenas a ação enquanto reposição da força de trabalho, a luta pela sobrevivência cotidiana.

Os Manuscritos prenunciam a sistematização mais elaborada, concretizada em $O$ Capital, na análise dos mistérios que a mercadoria oculta. Um mistério "ao mesmo tempo perceptível e impalpável”, que provém de sua própria forma ou da forma geral do valor que quantifica e torna equivalentes os trabalhos humanos nela embutidos; as mercadorias são pressupostas como iguais, a partir de uma série de abstrações necessárias para concretizar as relações de troca (MARX, 1980, p.79-80).

A mercadoria é misteriosa simplesmente por encobrir as características sociais do próprio trabalho dos homens, apresentando-as como características materiais e propriedades sociais inerentes aos produtos do trabalho; por ocultar, portanto, a relação social entre os trabalhos individuais dos produtores e o trabalho total, ao refletí-la como relação social existente, à margem deles, entre os produtos do seu próprio trabalho (MARX, 1980, p. 80).

Esse ocultamento dos elementos sociais do trabalho, ou seja, do modo como os homens se organizam, na produção e reprodução de sua vida material articulando suas atividades produtivas, do modo como transformam 
a natureza dispendendo suas forças fisiológicas e criando as formas de sociabilidade, não aparecem ou não são considerados no processo de quantificação do trabalho para fins intercambiáveis, fator que caracteriza uma abstração necessária para viabilizar as formas de troca. Por meio desse ocultamento "os produtos do trabalho se transformam em mercadorias, coisas sociais, com propriedades perceptíveis e imperceptíveis aos sentidos" (MARX, 1980, p. 81).

Na medida em que isso acontece ocorre uma inversão de perspectiva, que faz com que a "igualdade dos trabalhos humanos fique disfarçada sob a forma da igualdade dos produtos do trabalho como valores"; segue-se que a "medida, por meio da duração, do dispêndio da força humana de trabalho toma a forma de quantidade de valor dos produtos do trabalho"; nesse movimento, "as relações entre os produtores, nas quais se afirma o caráter social dos seus trabalhos, assumem a forma de relação social entre os produtos do trabalho" (MARX, 1980, p. 80).

Essa inversão se constitui, na aparência imediata dos sujeitos, na separação entre qualidade e quantidade, sujeito e objeto e "na medida em que o costume fixa essas proporções, parecem elas derivar da natureza dos produtos do trabalho" (MARX, 1980, p. 83). O aprofundamento das formas de abstração que possibilitam intercambiar os produtos do trabalho a partir da determinação de quantidades de valor permite a Marx mostrar que a raiz da auto-alienação dos homens (e da ideologia) se encontra no modo como se organizam as relações de trabalho e as relações de troca, a partir da constituição da forma mercadoria. A aparência imediata da atividade social como relação entre coisas que assumem independência em relação aos sujeitos do trabalho se desdobra na representação de si e do mundo; assim, por exemplo, a linguagem, um produto social dos homens, criada a partir de necessidades coletivas, aparece como a essência individual pela qual o homem se diferencia do restante da natureza.

Em síntese, ao desvendar o mistério da mercadoria e o seu caráter de fetiche, Marx explicita tanto o funcionamento do modo de produção capitalista em sua estrutura econômica e social quanto as relações ideológicas que a sustentam, ou seja, a vinculação interna entre o trabalho, a divisão social do trabalho e o modo de vida social, que se traduz em um modo de pensar, de sentir e de ver o mundo. A ideologia se expressa na inversão do imaginário no qual "uma relação social definida, estabelecida entre os homens, assume a forma fantasmagórica de uma relação entre coisas”. 
Esse fenômeno se denomina fetichismo, algo inseparável da produção de mercadorias (MARX, 1980, p. 81).

$\mathrm{O}$ enigma a decifrar se encontra no fato que os homens "fazem isto sem o saber" (MARX, 1980, p. 82), ou seja, tomam a aparência por realidade, a mercadoria como coisa independente do conjunto do trabalho social, exterior e estranha, passando a entender seu próprio trabalho como algo independente, objetivo, parte do mundo das coisas, força de trabalho submetida a leis externas e que lhe são estranhas. Daí decorre entender a linguagem como essência do humano e o passado histórico como constituído de fatos objetivos e estáticos no tempo, podendo ser retomados como de fato ocorreram. A mesma lógica instrumental que estrutura as relações econômicas e sociais, sedimenta-se no senso comum enquanto um conhecimento imediato, fragmentado e naturalizado, tomado como universal e verdadeiro.

Desvendar o segredo oculto da mercadoria na "determinação da quantidade do valor do tempo do trabalho" permite explicitar as formas da vida humana e "seguir a rota oposta à do seu verdadeiro desenvolvimento histórico”, ou seja, a história não pode ser lida linearmente, mas lida a partir "do fato consumado, quando estão concluídos os resultados do processo de desenvolvimento" (como Marx faz com a noção de mercadoria). E o "fato consumado" pode ser a visão invertida do real, porque oculta as múltiplas determinações que atuaram para a sua formulação (MARX, 1980, p. 84). $O$ Capital não é apenas um livro sobre economia política, mas uma obra filosófica que articula econômico, social, político e ideológico e o modo como estas instâncias se determinam reciprocamente formando uma nova teoria da história, como o coroamento de toda a produção teórica de Marx.

Essa breve incursão sobre o fetichismo da mercadoria pretendeu mostrar como Marx construiu a sua noção de ideologia a partir das categorias da economia burguesa no contexto de uma nova teoria da história que, a partir da explicitação do conjunto de relações econômicas, sociais, políticas e ideológicas, visa a transformar radicalmente a "estrutura do processo vital da sociedade" desvelando o "véu nebuloso e místico" que a encobre para criar uma nova ordem social e política (Marx, 1980, p. 88).

\section{Notas sobre ideologia a partir de A Ideologia Alemã}

Não é o esqueleto (em sentido restrito) que nos faz enamorar de uma mulher, mas compreende-se quanto o esqueleto contribui para a graça dos movimentos (Q. 1O, p. 1321). 
A breve abordagem que nos propomos aqui visa a mostrar, primeiro, que é a partir do empírico, mas não do imediatamente dado e sim do conjunto de relações nas quais os homens produzem e reproduzem a sua vida, que se forma a consciência; segundo, que este movimento de produção da vida tem um caráter eminentemente educativo que se traduz tanto nas normas de sociabilidade quanto no modo de ser e de pensar dos sujeitos. A metáfora em epígrafe visa a lembrar o modo como Marx, em O Capital, desvela o que se esconde sob a aparência social e o imediatamente dado, a fim de explicitar a estrutura vital da sociedade, compreendendo o "valor concreto (histórico) das superestruturas na filosofia da praxis" (Q. 10, p. 1321).

O ponto de partida de A Ideologia Alemã é, como acentuamos acima, a tradição filosófica hegeliana, nas leituras de Feuerbach e dos irmãos Bruno e Stirner, para mostrar que se esqueceram de "perguntar qual seria a relação entre a filosofia alemã e a realidade alemã", ou seja, a "relação entre a sua crítica e o seu próprio meio material” (MARX, 1976, p. 17). Esse "meio material” torna-se o objeto de análise de Marx, a fim de explicitar os limites da crítica dos filósofos hegelianos: as nossas premissas, diz Marx, "não são arbitrárias, nem dogmas"; são bases empíricas concretas: os "indivíduos reais, a sua ação e as suas condições materiais de existência”, tanto as históricas quanto as que eles próprios criam cotidianamente (MARX, 1976, p. 18).

Em seguida, pontua as condições de produção desses meios, que dependem em primeiro lugar da natureza, com a qual os homens estabelecem um modo determinado de atividade que transforma a natureza ao mesmo tempo em que os transforma e os define enquanto homens: a essência ou o modo de ser dos indivíduos "depende das condições materiais de sua produção", condicionando tanto a sua formação social quanto todo o seu desenvolvimento sensível e intelectual individual.

A base material ou pressuposto para se definir o que é o homem é o trabalho e a divisão social do trabalho, cujo desenvolvimento e graduação se traduz na separação entre os trabalhos específicos, entre cidade e campo, entre trabalho manual e trabalho intelectual, que modela a estrutura social e política. Aos momentos e à complexificação da divisão social do trabalho "correspondem formas diferentes de propriedade", assim como novas "relações entre os indivíduos no que toca à matéria, aos instrumentos e aos produtos do trabalho" (MARX, 1976, p. 20).

Na sequência, Marx (1976, p. 24) pontua as formas de propriedade que surgiram até a instituição da propriedade privada moderna e a sua 
consolidação na propriedade privada dos meios de produção. Tem-se então "sempre indivíduos determinados" em "relações de produção determinadas" a partir das quais "entram em relações sociais e políticas determinadas", dados gerados pela "observação empírica".

É desse contexto que se produzem as concepções de mundo, as ideias, forma-se a consciência: as "representações, o pensamento, o comércio intelectual dos homens surge aqui como emanação direta do seu comportamento material”. A produção das representações é, portanto, condicionada "por um determinado desenvolvimento das forças produtivas e do modo de relações que lhe corresponde", ou seja, o homem "é o seu processo da vida real" (MARX, 1976, p. 25).

A partir desse momento, Marx (1976, p. 25-26) inicia a explicitação do que significa a ideologia, inicialmente definida como a inversão do que seja o homem e suas relações, comparando o processo com a imagem invertida de uma câmara escura, que nos recorda o processo físico de produção da visão.

A consciência é um produto social, é fruto de uma determinada forma de relação do indivíduo com os outros, mas aparece como individual e separada do entorno. A base desse processo está na divisão social do trabalho, que gera as condições para que a consciência se emancipe do real existente e se proponha como puro pensamento, teoria "pura" que formula leis, "teologia, filosofia, moral, etc.” (MARX, 1976, p. 37). O filósofo (Feuerbach e companhia), assim como o homem comum,

não vê que o mundo sensível em seu redor não é objeto dado diretamente para toda a eternidade, e sempre igual a si mesmo, mas antes o produto da indústria e do estado da sociedade, isto é, um produto histórico, o resultado da atividade de toda uma série de gerações cada uma das quais ultrapassava a precedente, aperfeiçoando a sua indústria e o seu comércio, e modificava o seu regime social em função da modificação das necessidades (MARX, 1976, p. 30).

A partir da divisão social do trabalho se explicita o modo como se constitui a alienação: verificando-se a separação entre trabalho manual e trabalho intelectual, assim como a cisão entre interesse particular e interesse comum a partir da instituição da propriedade privada, a atividade passa a ser "dividida não mais voluntariamente", cada indivíduo passa a ter "uma esfera de atividade exclusiva que lhe é imposta e da qual não pode sair", para não perder os meios de subsistência; nesse contexto, "a ação do homem transforma-se para ele num poder estranho que se lhe opõe e o subjuga, em vez de ser ele a dominá-la” (MARX, 1976, p. 40-41). O trabalho deixa de ser 
meio de realização do homem como indivíduo completo e toda a vida fica reduzida a produzir os meios de sobrevivência.

Chega-se a um momento em que o trabalhador precisa enfrentar-se com dois fatos precisos: a objetivação das forças produtivas, que "já não são para os indivíduos as suas próprias forças, mas as da propriedade privada”; a conversão de cada um em indivíduo abstrato, sendo o trabalho, o "único laço que os une ainda às forças produtivas e à sua própria existência”; o trabalho "perdeu para eles toda a aparência de manifestação de si e só lhes conserva a vida definhando-a" (MARX, 1976, p. 91).

Esta redução que caracteriza a alienação é também lida como inversão ideológica, na constatação que "manifestação de si e produção da vida material estão de tal modo separadas que a vida material é considerada como fim e a produção da vida material", ou seja, o "trabalho, como meio (agora a única forma possível, embora negativa, da manifestação de si)" (MARX, 1976, p. 91-92).

Na medida em que a teoria se emancipa da realidade efetiva, a ideologia assume a função de ocultar esse conjunto estrutural na forma de teoria da história: a visão parcial dos dominantes assume a dimensão universal de verdade objetiva. A condição para manter-se no poder é "representar o seu interesse como sendo interesse comum", dando-lhes a "forma da universalidade", a fim de gerar a crença de que tais interesses sejam os “únicos razoáveis, os únicos verdadeiramente válidos”. Marx afirma aqui o que se expressa mais adiante no Manifesto do Partido Comunista, publicado juntamente com Engels: os "pensamentos da classe dominante são também, em todas as épocas, os pensamentos dominantes". A “classe que dispõe dos meios de produção material dispõe igualmente dos meios de produção intelectual”, para a sua conservação e domínio (MARX, ENGELS, 1978, p. 55-56).

O pensamento dos subalternos, que "não possuem os meios de produção intelectual” está igualmente "submetido à classe dominante”. Desse modo, a "existência de ideias revolucionárias numa época determinada pressupõe já a existência de uma classe revolucionária” (MARX, ENGELS, 1978 , p. 57). Tanto uma quanto a outra se produzem no movimento contraditório de fusão e cisão entre grupos e tendências que compõe as partes conflitantes em presença. Ao se defrontar com os grupos dominantes, a classe revolucionária aparece "não como classe mas como representante da sociedade inteira”, ou como representante dos interesses de todos os 
subalternos. É no movimento de luta e organização política que se definem as posições efetivas de classe, assim como a função dos intelectuais, que acabam dando a direção da história, sendo os "fabricantes da história", como os dominadores (MARX, ENGELS, 1978, p. 58-9).

Por tudo o que se acentuou, tem-se a assertiva de Marx em Para a crítica da Economia Política, segundo a qual as "formas ideológicas pelas quais os homens tomam consciência" de si e do mundo tem como base as condições econômicas de produção e a formação social, de modo que: "assim como não se julga o que um indivíduo é a partir do julgamento que ele faz de si mesmo", assim também "não se pode julgar uma época de transformação a partir de sua própria consciência"; para entender realmente o movimento histórico, "é preciso explicar esta consciência a partir das contradições da vida material, a partir do conflito existente entre as forças produtivas sociais e as relações de produção" (MARX, 1974c, p. 136).

No dizer de Guido Liguori (2007, p. 132-133), essa conotação negativa da ideologia expressa na primeira parte de $A$ Ideologia Alemã provavelmente era desconhecida para Gramsci, mas teve acesso a alguns elementos dela, na leitura do Prefácio de 1859 e de uma carta de Engels endereçada a Franz Mehring, datada de 14/07/1893, amplamente divulgada e que define ideologia como "falsa consciência". Gramsci provavelmente parte da combinação do Prefácio de 1859 com o escrito de Engels, para elaborar o seu conceito positivo de ideologia, como se apresenta nos Cadernos do Cárcere.

\section{A noção gramsciana de ideologia}

Se a crítica da ideologia se propõe a examinar os fundamentos sociais do pensamento, então, logicamente, deve ser capaz de fornecer alguma explicação de suas próprias origens históricas

(EAGLETON, 1997, p. 100).

Os Cadernos do Cárcere nos apresentam, no seu contexto geral, uma releitura do conceito de ideologia elaborado por Marx, na medida em que a ideologia é um momento da construção da hegemonia enquanto luta de classes. As classes dominantes criam os mecanismos ideológicos para a conformação das massas a seu projeto social e político e quando estes instrumentos não funcionam recorre-se ao uso da força; ao mesmo tempo, os grupos subalternos, na luta pela transformação da sociedade ou pela conquista da hegemonia, precisam elaborar uma nova concepção de mundo, um novo modo de pensar que se traduza em novo modo de vida para toda a sociedade. 
No Caderno 7 temos uma distinção importante, que mostra o distanciamento de Gramsci em relação ao conceito de ideologia como mera aparência: Um erro no qual incorrem algumas leituras do conceito é dar “o nome de ideologia seja à superestrutura necessária de uma determinada estrutura, seja às elucubrações arbitrárias de determinados indivíduos" (Q. 7, p. 868).

O processo deste erro pode ser facilmente reconstruído: 1) identifica-se a ideologia como sendo distinta da estrutura e afirma-se que não são as ideologias que modificam a estrutura, mas sim vice versa; 2) afirma-se que uma determinada solução política é 'ideológica', ou seja, insuficiente para mudar a estrutura, enquanto crê poder modificá-la se afirma que é inútil, estupida, etc.; 3) passa-se a afirmar que toda ideologia é 'pura' aparência, inútil, estupida, etc. (Q. 7, p. 868).

Trata-se de "distinguir entre ideologias historicamente orgânicas, necessárias a uma determinada estrutura” e importantes para organizar massas humanas, das ideologias arbitrárias (Q. 7, p. 868). As ideologias historicamente orgânicas são necessárias e se articulam com as estruturas, formando o horizonte no qual os homens se relacionam, lutam e conquistam consciência de suas posições e, portanto, são importantes na luta de classes ${ }^{3}$. A análise dessas relações explicita-se no "conceito de 'bloco histórico'[...]", 4 no qual as "forças materiais são o conteúdo e as ideologias a forma", sendo que "a distinção entre conteúdo e forma é meramente didática", porque forças materiais e ideologia se articulam dialeticamente e não seriam historicamente concebíveis uma sem a outra (Q. 7, p. 869).

Nesse embate, a fragilidade dos grupos subalternos se evidencia no fato que sua concepção de mundo é fragmentada e contraditória, porque assimilada do exterior; como já acentuamos a propósito da hegemonia, sua história "é desagregada e episódica", sem unidade, de modo que a tendência para se organizar "é sempre rompida pela iniciativa dos grupos dominantes" que são unificados pela mediação do Estado (Q. 25, p. 2283). É o Estado que garante a unidade histórica dos grupos dominantes, de modo que os grupos

\footnotetext{
3 Ainda no Caderno 7 (p. 869) uma anotação recorda de memória algumas afirmações de Marx como "a solidez das crenças populares", ou o "modo de conceber tem a força das crenças populares", ou ainda que "uma persuasão popular tem geralmente a mesma energia de uma força material ou algo similar", a serem confirmadas nos escritos.

4 O conceito "bloco histórico", retomado de Sorel, se articula ao conceito "espirito de cisão" para explicitar as novas estratégias de luta revolucionária. Na crítica a Coce a propósito do significado de filosofia da praxis, Gramsci acentua que a "afirmação das Teses sobre Feuerbach, de que o 'educador deve ser educado', não coloca uma relação necessária de reação ativa do homem sobre a estrutura, afirmando a unidade do processo real? O conceito de 'bloco histórico' construído por Sorel, toma precisamente na íntegra esta unidade defendida pela filosofia da praxis (Q. 10, p. 1300).
} 
subalternos alcançarão unidade somente no momento em que tomarem o Estado. A ideologia assume aqui uma função prática de garantia do poder instituído ou de necessidade objetiva para conquistar a hegemonia.

Conforme Guido Liguori (2004, p. 147), para Gramsci a ideologia "é a representação da realidade própria de um grupo social”. Para o indivíduo a ideologia se apresenta como visão de mundo, que expressa a visão de mundo do grupo do qual ele faz parte. "Os sujeitos coletivos são definidos pelas ideologias", que são o "lugar de construção da subjetividade coletiva, mas também - de modo mais contraditório - da ideologia individual, no âmbito da luta hegemônica”.

A questão das formas da ideologia enquanto formação da consciência e transformação da realidade, que interagem entre si, é abordada por Gramsci no Caderno 10, quando se pergunta: “o que é o homem?” E responde que o homem é o que pode se tornar, ou seja, "é o processo de seus atos". E neste processo o homem produz sua individualidade e sua visão de mundo na medida em que interage com os outros e com o meio em que vive; pode-se dizer que "cada um transforma a si próprio, se modifica, na medida em que transforma e modifica todo o conjunto de relações do qual ele é o centro de ligação", de modo orgânico e complexo. $\mathrm{O}$ "homem não entra em relação com a natureza simplesmente pelo fato de ser ele próprio natureza, mas ativamente, por meio do trabalho e da técnica", entendida como instrumento e pensamento articulados; por meio do trabalho e da técnica o homem concretiza relações "ativas e conscientes" que transformam a natureza na medida em que modificam o modo de ser e de pensar do homem (Q. 10, p. 1345).

A partir desses pressupostos, salientamos outras passagens dos Cadernos nas quais esta questão se esclarece:

Pela própria concepção de mundo pertencemos sempre a um determinado grupo, precisamente aquele no qual se encontram todos os elementos sociais que compartilham um mesmo modo de pensar e de agir. Somos conformistas de algum conformismo somos sempre homens-massa ou homens-coletivos. A questão é esta: de que tipo histórico é o conformismo ou o homem-massa do qual fazemos parte? (Q. 11, p. 1376).

Deduz-se que: a) a ideologia forma o nosso modo de pensar pelo qual nos conformamos a um determinado grupo social; b) a consciência, portanto, não é uma coisa somente minha, individual, mas formação social; c) o pensamento não é neutro e que expressa o meu vínculo a um grupo social; d) importante saber a qual grupo pertencemos (ou de que lado da 
luta de classes nos encontramos). Segue-se que "não existe a filosofia em geral: existem diversas filosofias ou concepções de mundo e se faz sempre uma escolha entre elas". Cabe definir esta escolha (Q. 11, p. 1378). Outro momento:

Um grupo social que possui uma concepção própria do mundo, embora embrionária, que se manifesta na ação e, portanto, descontínua e ocasionalmente, ou seja, quando tal grupo se movimenta como um conjunto orgânico, toma de empréstimo de outro grupo, por razões de submissão e de subordinação intelectual, uma concepção que não é sua e a afirma por palavras e também acredita seguí-la, porque a segue em 'tempos normais', isto é, quando a conduta não é independente e autônoma, mas submissa e subordinada. E é por isso que não se pode separar a filosofia da política, mas pode-se, ao contrário, demonstrar que a escolha e a crítica a uma concepção de mundo são, também elas, fatos políticos (Q. 11, p. 1379).

A questão da ideologia (modo de pensar) elabora-se no movimento que se faz de colocação e superação das contradições enquanto parte da luta de classes e da conquista da hegemonia, ou seja, é essencialmente um fato político, de modo que se pode dizer que a verdadeira filosofia de cada um se encontra contida em sua posição política (Q. 11). Decorre daí que é necessário conhecer as correntes de pensamento na sua situação concreta, ou seja, na sua dimensão política e histórica.

No Caderno 4 (p. 442-443) Gramsci retoma o período da Restauração francesa para mostrar como se elabora o "historicismo" na realidade efetiva e no âmbito da ideologia: o movimento de restauração, enquanto "conserva", na realidade efetiva, "grande parte das conquistas do período precedente" reconhecendo o "predomínio da grande burguesia" e consolida seu programa "civil", ideologicamente desenvolve sua filosofia política a fim de justificar sua posição e criar um equilíbrio das forças em presença que consolide a hegemonia.

Alguns parágrafos do Caderno 4 foram retomados e ampliados no Caderno 11, na crítica ao Ensaio Popular de Bukharin. Nesse contexto, Gramsci acentua que a filosofia que assume essa dimensão histórica relacionando teoria e prática é o marxismo, que é também "uma teoria da historia, uma teoria da política e uma teoria da economia", conceitos que se articulam em "uma unidade orgânica". Como "filosofia o materialismo histórico afirma teoricamente que toda 'verdade' que se crê eterna e absoluta tem origens práticas” e representou um valor provisório. Mas ao próprio materialismo histórico ainda é difícil compreender essa situação no que se refere a si próprio. “Também o materialismo histórico tende a tornar-se uma 
ideologia no sentido pejorativo, ou seja, uma verdade absoluta e eterna”. Isso acontece quando o materialismo histórico se confunde com o materialismo vulgar, como no Ensaio de Bukharin (Q. 4, p. 465-466; Q. 11, p. 1402 e 1447-1448). Somente a luta de classes e a clareza da dimensão ideológica dessa luta pode abrir caminho para a construção de uma nova ordem social e política e para a compreensão do caráter histórico da verdade.

Na sua crítica ao pensamento de Croce e sua leitura da história, Gramsci acentua que esse intelectual não conseguiu distinguir "filosofia" de "ideologia" e, consequentemente, não soube reconhecer a "obra-prima política pela qual uma determinada classe consegue apresentar e fazer aceitar as condições de sua existência e de seu desenvolvimento de classe como princípio universal”. Nesse movimento de organização política, a classe adquire clareza de si e do conjunto de relações de força e consegue superar níveis de compreensão da realidade e de sua concepção de mundo, expressão de um "inteiro grupo social concebido em movimento" e que consegue superar "seus interesses atuais imediatos" para alcançar interesses gerais e mediados pela teoria (Q. 10, p. 1231). Trata-se de um movimento de passagem do particular para o universal com nuances diferentes para os grupos sociais e para os indivíduos que os constituem, nuances que traduzem níveis de acesso ao verdadeiro (concreto e real). Na medida em que se luta e, nos embates, se organiza uma vontade coletiva, muda-se o modo de pensar individual e a percepção (coletiva e individual) das contradições e dos conflitos.

Para Frosini (2013, p. 32), o ponto de partida de Gramsci para a leitura de Marx sobre a questão da ideologia é o texto Teses sobre Feuerbach, de 1845, com desdobramentos em A Miséria da Filosofia. Nestes escritos Gramsci identifica as bases de uma nova filosofia cujo conteúdo de verdade se encontra na articulação entre teoria e prática. Dessa perspectiva "de verdade como praxis e da consequente redefinição da ideologia como uma prática política da verdade" 5 , deve ser abordada a leitura de Gramsci do Prefácio de 1859 ou a interpretação gramsciana da definição de Marx das “[...]'formas ideológicas' como o lugar onde 'os homens se tornam conscientes' do 'conflito' social e 'o enfrentam'[...]”, tese que Gramsci toma como “gnosiológica e não psicológica ou moral” (Q. 4, p. 463).

A questão gnosiológica implícita na análise e interpretação gramsciana dos escritos de Marx tem o objetivo claro de acentuar que a verdade emerge

5 Grifo do autor. 
da mediação dialética entre estrutura e superestrutura, movimento no qual se produz a ideologia enquanto constitutiva das relações de hegemonia. Cabe entender como as ideias e categorias são criadas no movimento de formação e desenvolvimento das relações econômico-sociais e se tornam expressão de interesses de classe, de modo que um fato pode apresentar uma "dupla fenomenologia”, ou seja, expressar um progresso do conhecimento da realidade e tornar-se, ao mesmo tempo, um elemento de ideologia, na medida em que instrumentalizado para o desenvolvimento do modo de produção capitalista, com expressão na cultura em geral (Q. 4, p. 433) .

Desse contexto Frosini (2013, p. 33 - grifos do autor) explicita que, de Marx, "Gramsci extrai essa posição filosófica: entre verdade e ideologia não há diferença de status: a verdade não é um fato lógico, mas político”; é a "afirmação prática de uma força social capaz de absorver em si mesma os interesses das outras classes populares de forma subalterna”. É na prática, no confronto das forças em disputa, que se constrói a universalidade que, por surgir na prática, é sempre parcial e provisória porque "os processos de unificação de uma sociedade dividida em classes sempre deixam uma margem não absorvida, um resíduo de passividade e de violência”. A possibilidade de uma universalidade sem resíduos, a partir da supressão da divisão em classes, é o que propõe a filosofia da praxis, enquanto "teoria da relação entre história, conflito e ideologia", para construir, "pela primeira vez", uma "universalidade sem resíduos, que não deixe fora de si uma parte da sociedade, e que não integre o resto de forma subalterna, mas em um plano de igualdade absoluta”. A universalidade, portanto, é algo a ser construído no movimento "das lutas pela emancipação de si e das demais classes oprimidas".

Da perspectiva de Finelli, este movimento de construção se apresenta na "passagem de uma classe da subalternidade do seu próprio não-ser histórico ao seu próprio ser e existir como sujeito" histórico, o que acontece no processo de organização política e supõe a "produção de uma subjetividade coletiva, através da produção de uma ideologia que se caracterize, ao mesmo tempo, pelo maior grau possível de coerência" interna e "pela mais ampla

6 O tema dos princípios gnosiológicos da filosofia da praxis explicitados por Gramsci foi por nós abordado no artigo Hegemonia e educação: os princípios gnosiológicos do pensamento e da ação (SCHLESENER, 2014, p. 51-69). Os termos "desenvolvimento" e "progresso" são utilizados no sentido que lhes atribuía Pasolini $(1982,1995)$, que os entendia opostos e contraditórios: o desenvolvimento não implica necessariamente progresso e até o exclui, visto que se atribui ao modo de produção e reprodução capitalista a partir da produção e do consumo de mercadorias sedimentados na produção de necessidades supérfluas; o progresso, ao contrário, implica a geração de novas formas de vida a partir da satisfação das necessidades elementares e necessárias para a liberdade e a igualdade de todos. 
universalização" (FINELLI, 2003, p. 107-108, grifos do autor). De todo modo, o universal pode passar a existir apenas no processo de construção de uma nova ordem social e política que se caracterize pela produção da igualdade coletiva.

Chatelet (1972, p. 202) acentua que, a partir da dimensão empírica que caracteriza a existência humana, pode-se distinguir "o que é fundamental" daquilo "que é histórico": existem condições objetivas que precisam ser reconhecidas como verdades, como, por exemplo, tem-se que reconhecer como verdade objetiva o fato que existem necessidades cuja satisfação é fundamental para a reprodução da vida humana; que a natureza humana se caracteriza por sua materialidade, a ser transformada pelo trabalho; a exploração da força de trabalho e sua redução a mercadoria, base da alienação, é um fato histórico a ser enfrentado. Marx procurou mostrar as contradições que se apresentam entre um universal legitimador de uma ordem social e política que tem uma dimensão histórica e que, portanto, é provisória e pode ser subvertida.

Gramsci reinterpreta Marx a propósito da questão da ideologia na crítica ao pensamento de Croce e às contradições nas quais este cai na sua leitura de Marx; neste contexto, define: "as ideologias são construções práticas, são instrumentos de direção política”. Para Marx, longe de serem ilusões e aparências, como entende Croce, as ideologias "são uma realidade objetiva e operante, mas não são a mola da história", porque "não são as ideologias que criam a realidade social, mas é a realidade social, na sua estrutura produtiva, que cria as ideologias" (Q. 4, p. 436).

$\mathrm{Na}$ interpretação de Liguori (2007, p. 137), esta expressão parece similar ao que diz Marx em A Ideologia Alemã: "Não é a consciência que determina a vida, mas a vida que determina a consciência”, embora não se saiba se Gramsci teve acesso ao conteúdo desse escrito, cuja primeira parte, Feuerbach, foi publicada em russo em 1924 e em alemão em $1926^{7}$.

Gramsci acentua que, para Marx, as ideologias "são uma realidade objetiva e operante, mas não são a mola da história”, no sentido que "não são as ideologias que criam a realidade social”, mas é ela que, "na sua estrutura produtiva, cria as ideologias". Também a teoria de Marx faz parte da superestrutura, com uma diferença fundamental em relação às outras ideologias: a sua teoria visa a "fazer 'tomar consciência' a um determinado

7 Cfr. Cesare Luporini, em publicação de 1967. Citamos a partir das informações de Guido Liguori. 
grupo social das próprias tarefas, da própria força, do próprio devir histórico”, ou seja, tem um teor de verdade primeiro, porque supera tanto as correntes idealistas quanto as leituras mecanicistas sedimentadas no materialismo filosófico vulgar e, superando-as, alcança um nível superior de conhecimento da realidade na mediação dialética entre teoria e prática; segundo, porque visa a esclarecer os subalternos dos grilhões invisíveis que os prendem com o objetivo de orientar as suas lutas. Para os grupos sociais dominantes, ao contrário, as ideologias servem como "instrumentos práticos de domínio político sobre o restante da sociedade”, mesmo estando essas ideologias em contradição com a realidade efetiva, ou seja, tenham o objetivo de obnubilar a realidade, esconder elos de submissão que existem na prática (Q. 4, p. 436-437).

Esse fragmento do Caderno 4 é retomado e redefinido no Caderno 10, onde a crítica à ideia croceana de que a ideologia é ilusão e aparência, Gramsci explica: as ideologias não são ilusões, nem aparências, "são construções práticas, instrumentos de direção política, ou seja, poder-se-ia dizer que as ideologias são meras ilusões para os governados", como um engano sofrido, enquanto para os governantes "são um engano voluntário e consciente" (Q. 10, p. 1319).

As ideologias são tudo menos arbitrárias: são fatos históricos reais que é necessário combater e desvelar na sua natureza de instrumentos de domínio, não por razões de moralidade, mas por razões de luta política: para tornar intelectualmente independentes os governados dos governantes, para destruir uma hegemonia e criar uma outra, como momento necessário de subversão da praxis (Q. 10, p. 1319).

Existe "uma diferença fundamental entre a filosofia da praxis e as outras filosofias": As ideologias dominantes são "criações inorgânicas porque contraditórias, criadas para conciliar interesses opostos e contraditórios" ocultando as contradições reais; porém as contradições tendem a aflorar e, com isso, a evidenciar os seus limites. A filosofia da praxis, ao contrário, "não tende a resolver pacificamente as contradições existentes na história e na sociedade, pelo contrário, é a mesma teoria de tais contradições; não é instrumento de governo de grupos dominantes para obter o consenso e exercer a hegemonia sobre as classes subalternas"; a filosofia da praxis "é a expressão destas classes subalternas que querem se educar a si próprias na arte de governo e que tem interesse em conhecer toda a verdade", mesmo as desagradáveis, a fim de evitar novos enganos (Q. 10, p. 1320). 
Aqui se explicita tanto os significados diversos de ideologia quanto os princípios gnosiológicos que fundamentam a filosofia da praxis que, enquanto teoria das contradições, é a expressão da verdade das relações de dominação que mascaram os conflitos sociais na sociedade capitalista e a dialética do próprio devir histórico, no qual se inclui enquanto teoria reconhecendo seus limites.

Essas formulações se ampliam se relacionadas ao Caderno 13, na leitura gramsciana de Maquiavel: o "caráter fundamental de $O$ Príncipe é o de não ser um tratado sistemático, mas um livro 'vivo'[...]”, ou seja, um livro que alia a teoria à prática e pelo qual Maquiavel explicita o "processo de formação de uma determinada vontade coletiva para um determinado fim político". Dessa perspectiva, o livro "poderia ser estudado como um exemplo histórico do 'mito' soreliano, ou seja, de uma ideologia política”, que atua sobre a "fantasia concreta de um povo disperso e pulverizado para despertar e organizar sua vontade coletiva” (Q. 13, p. 1555-1556). E Gramsci explicita os limites da noção de mito em Sorel, para acentuar os caminhos possíveis, a partir da análise da história italiana, para a formação de uma vontade coletiva nacional-popular.

O mito se apresenta não como utopia distante, mas como "uma criação da fantasia concreta", que serve para organizar uma população dispersa e desagregada em torno de um projeto comum. Os elementos míticos se expressam na convocação para a ação de um Príncipe efetivo, que Maquiavel apresenta no último capitulo do seu livro. Um líder verdadeiro que organize o movimento de fundação de um novo Estado. Esse elemento permite a Gramsci acentuar que o moderno príncipe deveria ser o Partido Político, evidentemente não um partido eleitoreiro como os que se organizam nos limites do Estado burguês, mas um partido que represente um novo projeto social e político. A esse ponto Gramsci aproxima o significado político da obra de Maquiavel ao Manifesto do Partido Comunista de Marx e Engels, mostrando que ambos, em momentos diferentes da história moderna, escreveram para classes revolucionárias que visavam a subverter a praxis a partir de seus projetos inovadores (Q. 13, p. 1556-1558).

A crítica ao mito soreliano se estende a todas as teorias que não levam até as últimas consequências a formação da vontade coletiva e a ação revolucionária por seus limites teóricos ou, ainda, práticos, tendo como pano de fundo a relação dialética efetiva entre teoria e prática ${ }^{8}$ : um projeto

8 Maquiavel, conforme Gramsci, escreveu para a classe revolucionaria de sua época, mas essa parece que não entendeu a mensagem, ou seja, não havia ainda, na prática, as condições necessárias para esse 
político que mobilize as massas não pode deixá-las no meio do caminho, sem sair de sua fase elementar e primitiva; precisa superar todos os entraves e encantamentos, tanto do mecanicismo ou do materialismo vulgar quanto do idealismo, além de considerar que a ação efetiva exige destruir para construir o novo, ou seja, implica sempre recorrer a alguma forma de violência (Q. 13, p. 1557). Uma vontade coletiva deixada na sua fase elementar e corporativa acaba se fragmentando em tendências que podem perfeitamente ser cooptadas pelas classes dominantes ou se dissolvendo enquanto projeto político, ou seja, Gramsci acentua a necessidade de uma racionalidade efetiva que se proponha dirigir em vista a um projeto político alternativo. Este é o sentido da luta9 ${ }^{9}$

O caráter inovador do projeto a ser levado avante pelo moderno príncipe consiste em "criar uma vontade coletiva ex novo, original, orientada para finalidades concretas e racionais, mas de uma concreticidade e racionalidade" que ainda não ocorreram como "experiência histórica efetiva e universalmente conhecida" (Q. 13, p. 1558).

Gramsci acentua aqui a natureza de uma revolução efetiva, que implica a originalidade da vontade coletiva enquanto consciência de sua força inovadora e de sua necessidade histórica, entendendo-se "protagonista de um drama histórico real e efetivo”. Um movimento de caráter jacobino, no sentido amplo que esta noção teve historicamente e no significado conceitual no qual deve ser entendida. Quando Gramsci acentua que se trata de um movimento que subverte todo o sistema de relações econômicas, sociais, políticas e ideológicas de modo novo e original está falando em uma verdadeira revolução a partir da organização das classes subalternas, na linha da política desenvolvida pelo L’Ordine Nuovo. Para tanto, as classes subalternas precisam entender o movimento das estruturas, as "razões dos sucessivos

entendimento, principalmente na Itália. Maquiavel foi compreendido pela primeira vez por Rousseau e Gramsci só pode fazer esta leitura depois de Marx e da consolidação da revolução burguesa na Europa, ou seja, depois do processo concluído.

9 “A ordem e a desordem são as duas palavras que aparecem com mais frequência nas polêmicas de caráter político. [...] A palavra ordem tem um poder taumatúrgico: a conservação das instituições políticas é, em grande parte, confiada a esse poder. A ordem presente apresenta-se como algo de harmonicamente coordenado, de estavelmente coordenado; e a multidão dos cidadãos hesita e se amedronta ante a incerteza daquilo que uma mudança radical poderia trazer. O senso comum, o estúpido senso comum geralmente prega que é melhor um ovo hoje do que uma galinha amanhã. E o senso comum é um terrível escravizador dos espíritos. Tanto mais quando para ter a galinha é necessário romper a casca do ovo. Forma-se na fantasia a imagem de uma coisa de violentamente lacerada; não se vê a nova ordem possível, melhor organizada e mais vital que a velha ordem, porque ao dualismo se contrapõe a unidade, à imobilidade estática da inércia, a dinâmica da vida movendo-se autonomamente. Vê-se somente a laceração violenta e a alma apavorada volta atrás com medo de perder tudo, de ter diante de si o caos, a desordem inelutável" (GRAMSCI, A. apud SCHLESENER, A. P. 2015, p. 197). 
fracassos das tentativas de criar uma vontade coletiva nacional-popular", assim como aconteceu com a burguesia comunal, a fim de enfrentar os conflitos na luta pela hegemonia (Q. 13, p. 1559).

O Caderno 13 é rico em análises a respeito das relações de forças, das dimensões que a luta de classes assume no cotidiano, dos encaminhamentos políticos no sentido da emancipação das classes subalternas e, principalmente, as formas que assume a ideologia no âmbito deste embate. Retomamos essas observações a propósito da educação e dos mecanismos ideológicos de formação da subjetividade porque entendemos, como acentua Dias (2012, p. 318), que o "domínio de uma classe (e de seu bloco de poder) determina o que pensar, o que estudar e até mesmo o que e como amar”. Ou seja, a ideologia assume uma dimensão desmesurada na medida em que serve para consolidar relações de domínio e a educação, em geral, funciona como o meio para a realização desses objetivos.

\section{A ideologia e a formação da subjetividade}

A verdade pode ser mortal e a mentira eterna? Tudo me leva a crer (BRECHT, 1982, p. 52).

Falar de ideologia implica abordar também a questão da educação, visto que é por meio da educação que se formam as concepções de mundo e a própria subjetividade. Da perspectiva gramsciana a educação se faz ao longo da vida e o indivíduo não é um ser isolado, mas, ao contrário, sua individualidade se produz na medida de seu envolvimento social. Toda a vida, por sua vez, tem uma dimensão política e histórica. A educação, para Gramsci, tem uma dimensão política revolucionária, visto que, para as classes subalternas, trata-se sempre de apropriar-se do conhecimento como consciência crítica, percepção das contradições e sua superação dialética.

Da perspectiva da sociedade capitalista e da hegemonia burguesa, a educação é um instrumento de adaptação ao contexto econômico e social que se objetiva consolidar e manter; educar é formar para a vida em sociedade, é conformar a projetos, é realizar uma ideia de civilização. Nesse contexto, a educação faz parte da própria natureza do Estado e de seus objetivos, visa uma determinada ordem social e determinadas relações de hegemonia, que se instauram e se renovam como correlação de forças.

Do ponto de vista das classes trabalhadoras, a educação pode ser um processo de adaptação à ordem instituída, mas pode também ser forma de 
reconhecimento dos conflitos sociais e de construção de uma identidade de classe. Significa organizar-se, interagir uns com os outros a fim de criar uma vontade coletiva, conhecer o conjunto de relações tanto em um dado momento histórico quanto em seu movimento de formação e transformação para tornarem-se ativos e capazes de organizar movimentos para mudanças efetivas.

De ambas as perspectivas, a questão da educação implica compreender as dimensões da luta de classes, nas formas mais atualizadas de participação em um horizonte ideológico que consolida a ordem instituída. A luta por novas relações de hegemonia produz-se como experiência de uma nova educação, que se apresenta para Gramsci como a formação de um novo homem que, por seu conhecimento crítico e ativo da realidade econômica e social em que se insere, é capaz de tomar nas mãos o seu destino.

A partir desses pressupostos cabe entender a questão da formação da subjetividade, não a partir do indivíduo isolado, mas a partir das formas como este indivíduo interage com o meio social e natural pela mediação do trabalho e como se torna conformista de algum conformismo. Cabe esclarecer que este conceito, o conformismo, é utilizado por Gramsci com um significado diverso daquele comumente usado na atualidade. No Caderno 13, parágrafo 7, Gramsci explicita esse conceito, implicitamente voltado a pensar a educação em uma nova sociedade:

Tarefa educativa e formativa do Estado, cujo fim é sempre criar novos e mais elevados tipos de civilização, de adequar a 'civilização' e a moralidade das mais amplas massas populares às necessidades do contínuo desenvolvimento do aparelho econômico de produção e, portanto, de elaborar também fisicamente tipos novos de humanidade. Mas como cada indivíduo singular conseguirá incorporar-se no homem coletivo e como ocorrerá a pressão educativa sobre cada um para obter seu consenso e a sua colaboração, transformando em 'liberdade' a necessidade e a coerção? Questão do ‘direito', cujo conceito deverá ser ampliado [...] (Q. 13, p. 1565-6)

Para Gramsci, o conceito “conformismo" pode ser tido como sinônimo de sociabilidade, ou seja, expressa uma situação de pertencimento a um determinado grupo social com o qual compartilhamos uma concepção de mundo, elementos da vida social que expressam um comportamento, um mesmo modo de pensar e de agir. Sempre "se é conformista de algum conformismo, sempre se é homens-massa ou homens-coletivos" e adaptar-se implica sofrer algum tipo de coerção. A questão é saber de que tipo de conformismo fazemos parte. "Quando a concepção de mundo não é crítica e coerente, mas ocasional e desagregada significa que pertencemos simultaneamente a 
uma multiplicidade de homens-massa" e a nossa personalidade se compõe dos elementos mais arcaicos combinados com elementos da ciência mais moderna. Qualquer projeto político alternativo implica fazer a crítica a esse modo de pensar desagregado e contraditório para formar uma concepção de mundo coerente e unitária (Q. 11, p. 1376).

Cabe acentuar que o homem é definido por aquilo que faz e toda ação exige um certo tipo de formação e de disciplina, processo que faz parte da educação. No Caderno dedicado ao americanismo e fordismo, Gramsci acentua que o processo civilizatório exigiu do homem esforços inauditos para se adaptar ao trabalho e a todas as exigências colocadas pela superação das necessidades, principalmente a partir do industrialismo, cuja história se apresenta como uma contínua luta de superação e aperfeiçoamento, muitas vezes doloroso e sangrento, na criação de formas sempre mais complexas de vida coletiva (Q. 22, p. 2160).

Gramsci, exceto a exploração do trabalho, não considera esse esforço de adaptação uma coisa negativa, mas entende como parte do processo de criação do homem, acrescentando que todo esforço físico, inclusive o mais mecânico e automatizado, em gestos simples e repetidos, exige um mínimo de atividade intelectual criativa. "Os industriais americanos entenderam muito bem esta dialética contida nos novos métodos industriais". Entenderam que "gorila amestrado" é uma frase, uma metáfora, porque o operário permanece homem e, portanto, pensa; e "não apenas pensa, mas a insatisfação no trabalho" pode levar o trabalhador a uma posição "não conformista” (Q. 22, p. 2170-2171).

Nesse contexto, a posição de Gramsci difere da de Marx quanto à formação da individualidade: Marx via na luta por uma nova ordem social e política a possibilidade de o homem realizar sua individualidade a partir da satisfação de seus desejos e capacidades individuais (MARX, ENGELS, 1976); Gramsci explicita e amplia esta noção ao articular o desenvolvimento individual com a vida coletiva e os interesses da sociedade da qual se faz parte.

A questão se apresenta no Caderno 13, a propósito do que significa "homem-coletivo" ou "conformismo social”, abordada como uma questão fundamental de educação, que implica o compromisso formativo do Estado no sentido de elevar as massas populares a um determinado nível de "civilização", adequando essas massas "às necessidades do contínuo desenvolvimento do aparato econômico de produção" elaborando "também fisicamente tipos novos de humanidade". Trata-se, para Gramsci, de explicitar como "cada 
indivíduo singular conseguirá incorporar-se no homem coletivo e como se fará a pressão educativa sobre os indivíduos para obter seu consenso e colaboração" a fim de transformar em "liberdade" a necessidade e a coerção. Gramsci atribui uma função importante ao direito como regulador desse processo e a necessidade de reformular as normas jurídicas em uma nova ordem social e política (Q. 13, p. 1566).

Deste contexto pode-se concluir que todo processo educativo implica alguma forma de coerção e de convencimento e que Gramsci entende que isso é necessário para adequar os indivíduos aos interesses do sistema produtivo e da sociedade em geral. Neste contexto, a escola é uma das instituições educativas que visa a cumprir esta função. A questão de fundo é que a individualidade é construída na vida coletiva, nas formas como se produz o "conformismo", que Gramsci classifica como podendo ser "imposto" ou "proposto", ou seja, aceito voluntariamente e, então, deixaria de ser realmente um "conformismo" (Q. 9, p. 1110).

Vemos neste fragmento que o conceito "conformismo" apresenta um aspecto negativo que se refere especificamente ao seu caráter impositivo. Gramsci procura mostrar a diferença entre individualismo e individualidade, acentuando que esta se elabora a partir de uma consciência crítica:

Que se lute para destruir um conformismo autoritário, que se tornou restrito e incômodo e atravessando uma fase de desenvolvimento da individualidade e personalidade crítica se alcance o homem-coletivo é uma concepção dialética difícil de compreender por meio da mentalidade esquemática e abstrata (Q. 9, p. 1111).

fundo, a individualidade se forma no contexto das relações sociais, no movimento histórico de produção e superação das contradições, entre as quais as mais variadas formas de coerção, desde a mais brutal, que passa pela violência física e adaptação do corpo, até a mais sutil, que envolve o convencimento por meio de mecanismos ideológicos. Cabe reconhecer no processo de conformação do indivíduo à sociedade o movimento educativo de superação dos grilhões ideológicos que o submetem; a formação de uma individualidade crítica e autônoma depende da compreensão do processo de interação social no qual o indivíduo se insere e se efetiva a educação.

Muitas são as ideologias que limitam a liberdade do homem e impedem que tome nas mãos o seu destino, entre elas as religiões de todos os matizes (ópio do povo, como dizia Marx), o jogo de azar ou as loterias (ópio da miséria, como acentua Gramsci, formas de fazer o pobre pagar imposto, além daquele que é retirado do seu salário), além de todas as outras crenças que 
impedem um pensamento autônomo. Educar implica atuar na formação da subjetividade da criança, tarefa delicada porque o limiar entre a disciplina necessária para tal formação e a coerção é muito frágil.

Embora Gramsci acentue as dificuldades de uma visão dialética do assunto, temos que concordar com Bodei (1999), que tanto a noção de disciplina quanto a de coerção são ambíguas e não estabelecem muito bem os limites entre o que é opção autônoma e o que é constrangimento, até porque o próprio Gramsci acentuava a propósito da censura, que a repressão constante se assimila e se interioriza, virando controle interno ${ }^{10}$. A amplitude de significados que assumem esses conceitos torna difícil defender uma disciplina, que pode assumir tanto a forma de uma imposição autoritária quanto se diluir na lenta formação do comportamento a partir da assimilação ou interiorização imperceptível da repressão.

\section{Elevar as massas ao maior nível intelectual: a importância da educação}

O poder distorce a visão dos céus impondo seus pesados telescópios sobre certas áreas, de modo que sua importância se amplia, obstruindo outras de forma avassaladora, que ficam

completamente invisíveis (BUCK-MORSS, 200o, p. 51).

A reversibilidade entre ser e conhecer Gramsci a aponta como uma das qualidades da filosofia da praxis. Um processo de formação difícil e complicado que se faz em seguir o movimento contraditório da vida, tanto na sua materialidade quanto na nossa imaginação. A filosofia da praxis é dialética, isso é, não se apresenta como um sistema explicativo e abstrato, mas como um pensamento aberto, histórico, inacabado e sempre recomeçado, que enfrenta o paradoxal, o ambíguo e o contraditório, como solo fértil para novas reflexões. Nesse contexto, as categorias fundamentais para a compreensão do movimento real deixam de ser a pura consciência de si e o pensamento voltado sobre si mesmo, mas a contradição e as formas que esta assume no processo de construção das condições materiais de existência. Esse é também um movimento de reconhecimento e superação das ideologias.

Se tomarmos a ideologia como parte da construção das relações de hegemonia, podemos afirmar a importância que assumem os intelectuais dos grupos dominantes no contexto das relações políticas, assim como o 
processo de educação escolar. A fim de contextualizar a questão, retomamos os pressupostos já colocados no primeiro capítulo: a sustentação dos escritos de Gramsci são as relações de força vigentes no seu momento histórico e, embora analisadas em confinamento, servem de base para explicitar a divisão da sociedade em classes bem como as características específicas dessa luta no momento de ascensão das forças fascistas. A análise dos conflitos gerados pelo antagonismo de classes e dos mecanismos ideológicos para a conservação da hegemonia permitem entender a relevância da educação para as classes trabalhadoras, tanto nas instituições regulares (como a escola) quanto nas organizações nascidas da luta por uma nova sociabilidade (associações de cultura, jornais, grupos de estudos, etc.).

Uma das bases para compreender os desdobramentos desse processo é o Caderno 13, quando Gramsci identifica nos escritos de Maquiavel as bases para entender a questão da hegemonia enquanto exercício do poder pelo equilíbrio entre coerção e consentimento. Gramsci acentua que Maquiavel, indiretamente, abordou a questão da ideologia ao divulgar um "princípio elementar da arte política que é o de que certas coisas se fazem, mas não se dizem”, ou seja, Maquiavel anunciou aos quatro ventos as práticas de poder que podem ser realizadas somente se não forem conhecidas pelas massas (Q. 13, p. 1675).

Ao tornar públicas tais práticas, Maquiavel as desmistifica e, consequentemente, as inviabiliza; nesta senda, esta pode ser uma das semelhanças da teoria política de Maquiavel com a filosofia da praxis: revelar a verdade a quem não sabe, a fim de possibilitar a sua emancipação política. Isso se torna possível na medida em que a base de análise é a realidade efetiva ou as conjunturas e estruturas em determinado momento histórico.

Gramsci faz outras aproximações entre Maquiavel e Marx, como mostrar que as duas teorias são revolucionárias, cada uma dirigida para a classe social que tem condições de fazer a revolução; ambas as teorias tem como base a desigualdade social que se constitui na origem da divisão entre dirigentes e dirigidos ou os que ordenam e projetam a sociedade e os que obedecem e se calam ou são calados; ambos os autores mostram que, no movimento de correlação de forças, as relações de poder podem inibir ou incentivar um comportamento, ou seja, são relações educativas em processo.

Desta perspectiva, ou seja, partindo-se do antagonismo de classes enquanto correlações de forças, defesa e conservação ou destruição e renovação da estrutura econômica e social (Q. 13, p. 1564), a educação escolar 
cumpre a função de adaptar os indivíduos aos interesses do mercado de trabalho e do sistema produtivo, mantendo a hierarquia dentre dirigentes e dirigidos; para as classes trabalhadoras, a escola é importante porque fornece os códigos necessários para a leitura das relações sociais e, como a sociedade é permeada por contradições, a educação escolar pode ser também um dos meios de formação para a emancipação política.

A questão da educação perpassa a teoria política na medida em que as relações de hegemonia são relações educativas e o Estado se apresenta, para Gramsci, como o principal educador, seguido pelo ambiente, que também educa, envolvendo todas as instituições sociais, desde a família, as igrejas, os meios de comunicação de massa, aparato jurídico, ou seja, todas as instâncias socais que formam o indivíduo ao longo de sua vida. Nessa estrutura social educadora elaboram-se e consolidam-se as ideologias no modo de ser e nas concepções de mundo que orientam e condicionam a vida de cada um.

A partir desses pressupostos, a perspectiva de Gramsci, ao analisar uma determinada situação, é saber em que medida ela serve para a formação emancipadora das classes populares ou para a conservação das relações de dominação e submissão. Porque a ideologia submete sem que o indivíduo ou o grupo se apercebam. A assimilação continuada de informações apresentadas como verdades absolutas e universais são fundamentais para a conservação de uma hegemonia alterando de modo decisivo a forma e o conteúdo da luta de classes.

Nessa sociedade marcada pela desigualdade social gerada pela exploração do trabalho não existem verdades absolutas e válidas indiferentemente para todos. O que é verdadeiro para os grupos dominantes não o é para os grupos dominados ou subalternos, embora eles a tomem como sua verdade; assim também acontece com algumas palavras abstratas e descontextualizadas que servem apenas para fortalecer os grilhões invisíveis que se consolidam como ideologia. Uma palavra exemplar é "paz”, que o senso comum repete como uma realidade que aspira sem se dar conta que, na estrutura contraditória e antagônica desta sociedade, a paz é uma miragem.

A filosofia da praxis se propõe analisar a realidade para "organizar racionalmente aquilo que os agentes históricos desta realidade sentem confusa e instintivamente". Para tanto, colocou-se como tarefas "combater as ideologias modernas na sua forma mais refinada e esclarecer as massas populares, cuja cultura era medieval” (Q. 4, p. 422). Ou seja, Gramsci acentua 
que uma das tarefas do marxismo é elevar o nível cultural das massas populares, processo essencialmente educativo que consiste em mostrar às classes trabalhadoras a necessidade política de se reconhecerem no movimento contraditório de construção da sociedade e de refletirem sobre suas lutas, seus sonhos e seus projetos. A educação, nesse contexto, se articula com o conceito de hegemonia, que tem como pressuposto a luta de classes e o espírito de cisão, ou seja, a formação de uma consciência crítica capaz de ler os detalhes do real e de promover uma reforma intelectual e moral como parte de um processo revolucionário.

Reconhecer-se no movimento contraditório das relações sociais significa entender o processo de dominação alicerçado na estrutura do modo de produção para tomar novas dimensões no modo de pensar, na medida em que as classes dominantes se apropriam do passado cultural apresentando-o numa versão homogênea e sem conflitos, para consolidar seu poder. Nesse contexto, elevar as massas ao maior nível intelectual significa entender que as novas características da luta de classes implicam enfrentar o dominador no mesmo terreno, ou seja, elaborar uma consciência crítica e a sua própria concepção de mundo a fim de reinterpretar todo o passado cultural a partir de uma perspectiva mais abrangente da realidade. Embora a abordagem suponha a formação de uma identidade de classe, o conhecimento a ser produzido da perspectiva da filosofia da praxis não é um conhecimento a ser guardado e utilizado pela própria classe para uma nova forma de dominação, mas precisa ser coletivizado, o que significa torná-lo fonte de libertação para toda a humanidade.

Essa questão torna-se fundamental, porque a fragilidade dos vencidos se determina pelo fato de que não possuem clareza de sua própria história, porque esta não tem uma narrativa organizada que evidencie suas práticas e interesses de classe. E essa formação se torna mais importante e urgente na medida em que o conhecimento se transforma em instrumento de poder e de aprofundamento das desigualdades sociais. Para as classes trabalhadoras ter acesso ao conhecimento historicamente produzido significa ter acesso aos instrumentos de libertação da dominação capitalista, sem os quais torna-se muito difícil superar as limitações impostas e efetivar a construção de uma nova ordem social e política.

Como acentua Dias (2012, p. 123), "quando os intelectuais burgueses pensaram sua passagem ao comando das sociedades europeias eles o fizeram do ponto de vista da modernidade". Como tal, pensavam em implementar direitos, a "liberdade de saber, pensar, expressar novas convicções" e a 
ciência como "possibilidade de diminuir o sacrifício físico na produção e criar a igualdade na política, como libertadora". O que realizaram efetivamente foi uma modernidade de acordo com seus limites, como um novo modo de vida, mas determinado por interesses de classe.

O capitalismo, por suas próprias necessidades e limitações, "afirmou a liberdade abstrata dos indivíduos-mônadas" e a liberdade efetiva dos proprietários. Os ideais revolucionários eram "incompatíveis com a produção, só cabendo aí a 'liberdade capitalista', a da extração legalizada do mais-valor" (DIAS, 2012, p. 130-131). Elevar as massas ao maior nível intelectual significa proporcionar-lhes as condições de romper com esse processo repetitivo de dominação e, para tanto, torna-se necessário redefinir o processo educativo.

Esse tema implica explicitar a questão da linguagem na sua dimensão política; se a hegemonia se produz e se conserva como equilíbrio entre coerção e consenso e este se forma no cotidiano imediato pela formação de um modo de pensar homogêneo, evidente que a linguagem se torna o meio de veiculação da ideologia e das ideias dominantes. E novamente a importância dos intelectuais se evidencia, principalmente quando se constituem em casta que controla e veicula o pensamento. A questão a ser enfrentada nesse contexto é mostrar que, na história, o controle da palavra sempre pertenceu aos dominantes e na sociedade moderna, mais do que nunca, esse poder se multiplicou com a inserção das novas tecnologias de comunicação e, consequentemente, romper grilhões e vencer as lutas políticas implica dominar a linguagem e formular um pensamento autônomo para enfrentar o dominador no seu terreno. Esse tema desenvolveremos a seguir. 


\section{CAPÍTULO III \\ A linguagem em seu contexto histórico E POLÍTICO ${ }^{1}$}

O escrito é como uma cidade, para a qual as palavras são como mil portas (BENJAMIN, 2009).

A pergunta sobre a linguagem e a sua colocação como paradigma no contexto da filosofia contemporânea nos move a outras interrogações: por que a valorização da dimensão simbólica e cultural no momento em que a sociedade se afirma cada vez mais no movimento de produção e consumo globalizados? É apenas o simbólico que nos diferencia das demais espécies de animais, ou as contradições implícitas em nossa vida social indicam a necessidade de outros parâmetros? $\mathrm{O}$ fato de concentrar-se em uma dimensão do humano sem considerar os elos sociais, políticos e culturais produzidos no contexto da sociedade moderna não seria um sintoma de uma opção política? O que pode ainda orientar a ação e a formação do homem numa sociedade na qual imperam objetivos estritamente mercantis e instrumentais? Como retomar a articulação das múltiplas determinações da vida humana num conhecimento que expresse o real em seu movimento num contexto que se fecha a leituras gerais e se fragmenta em especialidades também no campo da filosofia? Enfim, qual o significado político e pedagógico da linguagem nas suas várias formas de enunciação?

De uma perspectiva interdisciplinar, quando se fala em linguagem pensa-se imediatamente na oralidade como a forma de expressão por excelência. Entretanto, como acentua Pasolini (1995, p. 199), a "primeira e principal das linguagens humanas pode ser considerada a própria ação, enquanto relação de representação reciproca com os outros homens e com a realidade física".

E nessa senda, a imagem, a música, a poesia, o teatro, o cinema, a arte em geral e todas as manifestações simbólicas geradas a partir do

1 Parte do conteúdo deste capítulo foi retomado de: SCHLESENER, A. H. A linguagem e seu significado político e pedagógico a partir dos escritos de Gramsci. In: GOMES, V. C., SOUSA, J. R. e RABELO, J. J. (Orgs.). Gramsci, educação e luta de classes. Fortaleza: Imprensa Universitária, 2015a. 
desenvolvimento da imprensa e das demais tecnologias de comunicação constituem-se linguagem. Ou seja, ainda nas palavras de Pasolini (1995, p. 199), é como se o agir portasse em si um tipo especial de irracionalismo, um dado que se impõe no mundo moderno; trata-se de uma grande "violência exercida sobre nós por uma sociedade que, assumindo a técnica em sua filosofia, tende a tornar-se sempre mais rigidamente pragmática e a identificar as palavras com as coisas e as ações”, ocorrendo um fenômeno de desapropriação da palavra em favor de elites que controlam as línguas-guias.

Esse tema nos interessa porque se depreende de algumas leituras de filólogos, que a linguagem vem abordada prevalentemente como teoria linguística, sem a dimensão política que perpassa todo o pensamento de Gramsci. Curiosamente, nosso primeiro artigo sobre os escritos de Gramsci, publicado em 1983, tinha como objetivo salientar a dimensão política e ideológica da linguagem, de uma forma ainda introdutória por ser resultado de uma primeira abordagem.

A questão da linguagem, nos Cadernos do Cárcere, vem sempre relacionada com a cultura e a filosofia, sendo que todas as abordagens tem como pano de fundo as relações de poder; isso se torna possível a partir da crítica marxiana ao pensamento hegeliano, mostrando que a atividade filosófica precisa mudar de objeto e de perspectiva: o objeto da filosofia deixa de ser a busca do fundamento universal para fixar-se na realidade efetiva e concreta, a fim de explicitar o processo contraditório de formação da sociedade; por isso, a filosofia da praxis precisa efetuar uma crítica da linguagem na sua dimensão ideológica.

As classes dominantes, em cada momento histórico, se apropriam do passado cultural para consolidar seu poder e essa apropriação passa pelo domínio da linguagem. A necessidade dessa crítica em seus efeitos políticos exige a explicitação e aprofundamento do conceito de hegemonia enquanto dominação sedimentada pela formação continuada do consenso, que se consolida por meio da difusão de um pensamento homogêneo, que acaba por relegar as classes trabalhadoras a uma situação de subalternidade e submissão. Essa questão se torna fundamental no enfrentamento político, visto que a fragilidade dos vencidos também se sedimenta no fato que não possuem clareza de sua própria história e dos motivos de seus fracassos, porque não possuem uma narrativa organizada que evidencie suas lutas e interesses de classe; a história que conhecem e que tomam como verdadeira é sempre a história da perspectiva dos vencedores. 
Cabe aqui esclarecer os significados que Gramsci atribui a esses conceitos: a filosofia, para nosso autor, possui uma dimensão essencialmente política, ou seja, "deve tornar-se política para continuar a ser verdadeira, para continuar a ser filosofia” (Q. 11, p. 1472). A base dessa afirmação se encontra no Caderno 11, \& 12, que apresenta os pressupostos para a dimensão política da filosofia: que "todos os homens são 'filósofos'[...]”, vivendo no cotidiano, ainda que inconscientemente, conforme uma filosofia contida "na própria linguagem enquanto um conjunto de noções e conceitos determinados e não somente de palavras gramaticalmente vazias de conteúdo", no senso comum e na religião popular (Q. 11, p. 1375).

A política precisa ser entendida em seu sentido amplo, ou seja, a partir do modo como se estruturam as formas materiais de existência na sociedade capitalista e a sua expressão no modo de ser da sociedade; a nossa inserção no contexto da estrutura define o caráter político de nossa ação, visto que precisamos permanentemente nos posicionar no âmbito das lutas de classes. Estas, por sua vez, enraízam-se no modo de produção material e se reproduzem a partir das múltiplas articulações que compõem as formas de vida em geral. Enfim, a cultura assume significado e importância na medida em que as relações políticas se constroem fundadas na ideologia como prática de poder, ou seja, tanto filosofia quanto cultura tem como ponto de inflexão a centralidade da política. Na sociedade capitalista as relações de poder se constroem como dominação econômica que se sustenta e se consolida pela direção intelectual e moral a partir da formação do homem e de sua conformação aos interesses do trabalho.

A direção intelectual e moral apresenta-se como uma das principais condições, tanto para a conquista quanto para o exercício do poder, constituindo-se no elemento que materializa a dominação e a subalternidade por meio da formação do modo de vida. A divisão do trabalho que caracteriza o cotidiano nas relações sociais em geral (patrão-empregado, professor-aluno, dirigentes-dirigidos, governantes-governados) garante o equilíbrio das relações de forças entre as classes que se formam no contexto da produção e do consumo. Essas relações são naturalizadas e interiorizadas no processo educativo. Nesse contexto, a dimensão simbólica adquire significado político e a linguagem materializa as relações de poder consolidadas e interiorizadas pelas classes ou grupos sociais que interagem entre si.

A apropriação de uma linguagem (ou de uma concepção de mundo) assume importância fundamental no contexto das relações de poder capitalistas, na medida em que a hegemonia se sustenta pela divulgação e 
consolidação de um pensamento homogêneo. Expressar-se de modo claro e autônomo implica formalizar de modo orgânico as ideias e valores implícitos na ação e gerar as condições de um pensamento inovador assume uma força política inusitada no momento em que o conhecimento se transforma em instrumento de poder e dominação. Consolidar um pensamento hegemônico significa tolher das classes trabalhadoras a sua fala inovadora e torná-las reprodutoras do instituído e consolidado. Daí a importância da linguagem, tratada não apenas como lógica ou teoria que determina a ação, mas, ao contrário, como a expressão de um modo de ser e agir que se transforma no processo histórico e que, por sua vez, repercute na estrutura lógica de uma língua.

A crítica da linguagem se torna, assim, uma questão política fundamental para as classes trabalhadoras na medida em que a ideologia toma novas dimensões com o desenvolvimento dos meios de comunicação de massa, que se tornam mecanismos educativos cujo poder se encontra em divulgar uma ideologia como se fosse a verdade universal e não a expressão de interesses de classe, tolhendo a subjetividade do trabalhador que, ao assimilar o modo de pensar e o modo de vida dominantes, perde a sua autonomia política de organização.

\section{Breves observações sobre a questão da linguagem em Marx:}

As modificações das estruturas sociais, com as suas consequências culturais, etc., são a linguagem com a qual se expressam os revolucionários. Lenin, de certo modo, deixou escrito um grande poema de ação (PASOLINI, 1995, p. 200).

As bases de Gramsci para a crítica da linguagem se encontram em Marx, do qual retomamos alguns escritos para salientar que a dimensão simbólica, principalmente na linguagem oral, constrói-se como uma das dimensões da vida econômica, social e política, na forma de consciência ideológica. Trata-se de uma breve exposição, a fim de delimitar o contexto a partir do qual a linguagem se apresenta como a expressão empírica das formas de dominação hegemônica e ideológica explicitadas por Gramsci.

Partimos do seguinte ponto: a diferença de fundo entre Marx e o idealismo hegeliano se encontra principalmente no entendimento do homem a partir de sua historicidade, ou seja, a história não consiste no devir e na realização do logos, mas sim no movimento de produção e reprodução da vida pela mediação do trabalho. Pode-se argumentar que existem outros 
animais que trabalham e, portanto, o trabalho não pode consistir na diferença pela qual o homem se distingue e constrói a sua essência humana. No contexto da história da filosofia, já Aristóteles reconhecia que a diferença entre o homem, as abelhas e as formigas é que o trabalho humano é criador e transformador da natureza e do próprio homem.

Pela mediação do trabalho enquanto atividade material concreta, determinada pelas circunstâncias históricas, o homem cria as suas condições de viver e com elas o seu modo de ser, ou seja, ao renovar cotidianamente a própria vida, cria laços familiares, relações sociais, políticas e culturais, formando, nesse movimento, a sua subjetividade. Em outras palavras, os homens precisam produzir os meios de subsistência ou de sobrevivência antes de "fazer história" ou interpretar o mundo (MARX, ENGELS, 1976). O "agente histórico não é o homem que pensa e fala, mas aquele que produz e reproduz as condições de sua existência sensível”; não é o intelectual, mas o homem que "maneja o arado, o chicote ou a espada, que troca os produtos de sua atividade ou que vende a força de seu trabalho" (CHATELET, 1972, p. 227).

O leitor de Marx conhece as premissas das quais o autor parte e que são assinaladas em A Ideologia Alemã: a empiria, ou seja, os indivíduos e suas condições materiais de existência, são "bases verificáveis por vias puramente empíricas". E se acrescenta no texto: "pode-se referir a consciência, a religião e tudo o que se quiser como distinção entre os homens e os animais; porém, esta distinção só começa a existir quando os homens iniciam a produção dos seus meios de vida”, vale dizer, sua vida material (MARX, ENGELS, 1976, p. 18-19).

Trata-se de substituir a noção metafisica de uma essência humana a priori, que sempre encantou (e continua encantando) os filósofos e que culminou no idealismo hegeliano (que, embora reconhecendo a historicidade da sociedade, manteve as bases legitimadoras do discurso metafisico na ideia do Espirito Absoluto) por uma abordagem do movimento histórico no qual o homem, "em sua atividade sensível, forja sua própria realidade" e a interpreta (CHATELET, 1972, p. 227). Ou seja, indivíduos historicamente situados, com uma atividade produtiva determinada, que entram em relações sociais e políticas determinadas, a partir das quais conhecem a si mesmos e aos outros elaborando a sua interpretação da realidade.

A chave de leitura da realidade (ou paradigma de Marx, se a base de leitura de Marx for o pensamento chamado “pós-metafísico”) é o modo de 
produção e, nos seus desdobramentos, a consequente luta de classes e não a linguagem. A materialidade que caracteriza a produção da vida é condição para a produção do conhecimento e não o contrário; o próprio Marx explicita que é a divisão social do trabalho que, ao separar trabalho manual de trabalho intelectual, possibilita a ilusão de que o pensamento tem prioridade sobre o material e manual. O objetivo da filosofia em Marx deixa de ser a busca do fundamento universal para voltar-se para a realidade efetiva e concreta, o processo contraditório de formação e construção das sociedades. E não se trata de mostrar o que veio antes ou depois, o trabalho ou a linguagem, numa leitura dualista que descaracteriza o pensamento marxiano, mas de acentuar a relação dialética entre ação e pensamento, que foram separados de modo dualista a partir da divisão social do trabalho.

A inversão radical proposta por Marx em relação à filosofia alemã fica explicita: "não se parte daquilo que os homens dizem, imaginam e pensam nem daquilo que são nas palavras, no pensamento, na imaginação e na representação de outrem", mas parte-se dos homens em carne e osso, na "sua atividade real” (MARX, ENGELS, 1976, p. 26). A partir desses pressupostos e dessa inversão de abordagem, pela realização da dialética levando-a a suas últimas consequências, é que a questão da linguagem se coloca.

A linguagem é tão velha quanto a consciência: é a consciência real, prática, que existe também para outros homens e que, portanto, existe igualmente só para mim e, tal como a consciência, só surge com a necessidade, as exigências dos contatos com os outros homens. [...] A consciência é pois um produto social e continuará a sê-lo enquanto houver homens (MARX, ENGELS, 1976, p. 36).

Importante salientar que a frase cortada do manuscrito acentua que a consciência é relação com tudo o que nos rodeia. Ou seja, sendo relação, a consciência está também condicionada pela forma de sociedade da qual se faz parte, pelas circunstâncias sociais geradas a partir das relações de trabalho. Vale dizer que todo conhecimento é historicamente produzido, não é neutro, mas traduz relações de poder que se produzem no âmbito das lutas de classes. Isso nos remete a um outro texto de Marx no qual a questão da linguagem reaparece, sempre determinada pelas circunstancias históricas: O 18 Brumário de Luiz Bonaparte.

Os homens fazem a sua própria história, mas não a fazem como querem; não a fazem sob circunstâncias de sua escolha e sim sob aquelas com que se defrontam diretamente legadas e transmitidas pelo passado. A tradição de todas as gerações mortas oprime como um pesadelo o cérebro dos vivos. E justamente quando parecem empenhados em revolucionar-se a si e às 
coisas, em criar algo que jamais existiu, precisamente nesses períodos de crise revolucionária, os homens conjuram ansiosamente em seu auxílio os espíritos do passado, tomando-lhes emprestado os nomes, os gritos de guerra, as roupagens, a fim de se apresentar nessa linguagem emprestada (MARX, 1977, p. 17-18).

Entre outros elementos importantes, essa citação de Marx frisa o conteúdo ideológico da linguagem, ou seja, consciente ou inconscientemente a linguagem, enquanto expressão do real, também o mistifica. A linguagem e a interpretação formam o imaginário social que se realimenta do passado para explicar e sustentar as lutas do presente. A rememoração dos atos heróicos do passado serve tanto para impulsionar a ação transformadora do presente quanto para ocultar os limites e as contradições do projeto que se pretende implementar (MARX, 1977). Como pano de fundo do uso da linguagem e da história, a luta de classes, na correlação de forças entre o novo que quer nascer e o velho que não quer morrer, nas figuras de uma classe emergente que aspira ao poder e conjura em seu favor as vitórias do passado, outra que perde seu domínio e tenta manter-se no poder e, para isso, ressuscita os momentos privilegiados de seu passado. A linguagem torna-se aqui um instrumento político da maior grandeza, com outras conotações frisadas por Marx:

De maneira idêntica, o principiante que aprende um novo idioma, traduz sempre as palavras deste idioma para sua língua natal; mas só quando puder manejá-lo sem apelar para o passado e esquecer sua própria língua no emprego da nova, terá assimilado o espirito desta última e poderá produzir livremente nela (MARX, 1977, p. 18).

A aprendizagem de uma nova linguagem, que supõe o esquecimento do idioma de origem, tem como pressuposto a formação cultural e os elos que ligam os subalternos ao horizonte ideológico de seu tempo a partir dos laços de submissão que foram construídos historicamente. O conteúdo ideológico que se sedimenta na linguagem e dificulta a assimilação do novo ou mesmo a sua proposição, implícito nessa citação de Marx, nos remete ao pensamento de Gramsci sobre as relações de hegemonia que se consolidam e se perpetuam na formação do senso comum e na incapacidade dos subalternos de formular um pensamento inovador, que expresse realmente o conteúdo de suas lutas.

Ou seja, Gramsci interpreta e renova a questão da linguagem a partir da explicitação das novas formas de dominação que se ampliam com a inserção das novas tecnologias de produção e de comunicação de massa. Gramsci 
parte da crítica ao pragmatismo (que poderia ser estendido ao campo da filosofia analítica) e procura mostrar que a política alia-se cada vez mais à cultura para consolidar as relações de poder, de modo que as lutas de classes assumem uma nova dimensão que passa pela necessidade de um trabalho educativo-formativo das classes trabalhadoras, a fim de criar sua própria interpretação do mundo e, com isso, a sua identidade de classe. Para tanto, um dos caminhos é valorizar a sua linguagem, expressão de sua vida e de suas lutas; outro caminho vinculado ao anterior é aprender a traduzir para superar os limites do senso comum e de um pensamento homogêneo que sustenta a hegemonia burguesa.

A questão a ser enfrentada em se tratando da linguagem é mostrar que, na história, o controle da palavra sempre pertenceu aos dominantes e na sociedade moderna, mais do que nunca, esse poder se multiplicou com a inserção das novas tecnologias de comunicação; de modo que as classes trabalhadoras, para vencer as lutas políticas, precisam se reconhecer no movimento contraditório de construção da sociedade e, para isso, necessitam dominar a linguagem para enfrentar o dominador no seu terreno. Nesse contexto, o pressuposto para refletir sobre a questão da linguagem é a luta pela hegemonia, a qual implica necessariamente fazer a leitura da história, a fim de identificar-se como classe e apresentar-se como projeto político e social alternativo.

Os dois conceitos, hegemonia e linguagem, por sua vez, embasam o significado pedagógico que permeia a política e se organiza a partir da luta de classes. Pensar a educação, em particular a educação escolar, implica entender os mecanismos de elaboração das políticas públicas e os interesses que essas escondem no âmbito da luta de classes; a partir desse pressuposto, salientar a importância, para as classes trabalhadoras, do ensino escolar, principalmente porque por meio da escola se tem acesso ao domínio dos códigos de comunicação necessários para a formação de um pensamento coerente e como instrumento de contestação do poder instituído.

\section{"Esta mesa redonda é quadrada": a questão da gramática}

Abandonei a ideia de escrever (por força maior, dado a impossibilidade de conseguir o material necessário) uma dissertação com o título: "Esta mesa redonda é quadrada" que, penso, tornar-se-ia um modelo para os trabalhos intelectuais carcerários presentes e futuros (GRAMSCI, 1975d, p. 157) 
Gramsci foi um estudioso de linguística e poderia ter se tornado professor e pesquisador, não fosse a sua paixão pela política. ${ }^{2}$ Os Cadernos do Cárcere nos contemplam com vários fragmentos sobre os temas da linguagem e da gramática. A questão lógica que tomamos como título desse capítulo faz parte do \& 1 do Caderno 29 (escrito em 1935), retomando o $15^{\circ}$. ponto de pesquisa anotado no Caderno 1 em fevereiro de 1929: Neogramáticos e neolinguístas ("esta mesa redonda é quadrada"). O tema envolve a questão: “o que é a gramática?” ou: qual a relação entre a estrutura lógica do pensamento e o modo de vida ou a atividade concreta?

A crítica gramsciana da linguagem no seu confronto com a lógica e o pragmatismo, na vertente de Giovanni Vailati, mostra os limites da gramática se ela for abordada apenas no contexto do significado abstrato das palavras. Gramsci defende a dimensão política da linguagem e seu caráter metafórico, a partir do qual reflete sobre as possibilidades de tradutibilidade das línguas e sua dimensão ideológica, questão que assume atualidade a partir da nova dimensão no contexto da chamada "sociedade do conhecimento" e da comunicação, onde as novas tecnologias fortalecem os mecanismos de dominação política e econômica da sociedade capitalista.

Inicia-se com uma clara crítica a um ensaio de Benedetto Croce no qual o autor parte do estatuto gramatical da palavra para mostrar que sua estrutura lógica deve valer também para a estética. Se uma proposição não é lógica não pode ser pensada nem imaginada e, portanto, não tem sentido. Conforme Croce, é a definição gramatical da palavra que determina o seu uso.

Para Gramsci, ao contrário, o estatuto gramatical de uma palavra se estabelece a partir do contexto histórico (e político, como veremos adiante) e das necessidades de comunicação dos falantes, de modo que uma "proposição, ainda que não 'tecnicamente' gramatical”, possui uma função "expressiva e justificada”, mesmo que negativa ou contraditória. Os chamados "erros gramaticais" resultam basicamente de uma "ausência de disciplina mental, neolalismo, particularismo provincial, jargão, etc.”, ou seja, de uma falta de

2 Conforme Lo Piparo (2014, p. 160), Gramsci era conhecido nos meios científicos por sua dedicação ao estudo da filologia e glotologia; por ocasião de sua prisão publicou-se na Revista "Weltbuhne" informações sobre o processo de Roma, cujo acusado era "um dos mais importantes teóricos do movimento operário, de apenas 36 anos e bem conhecido no inteiro mundo cientifico [...] em 1919 foi convidado para uma cadeira na Universidade de Hamburgo, que recusou para não renunciar ao seu compromisso político". Os biógrafos de Gramsci não deram importância a esta notícia. Embora estejamos salientando esta observação de Lo Piparo, acentuamos que discordamos de sua leitura de Gramsci no livro citado, na medida em que encontramos vários equívocos quanto ao que se refere ao conceito gramsciano de linguagem. Essa questão é controversa. 
coerência lógica que pode decorrer de uma concepção de mundo fragmentada e assimilada sem critério, a partir da vivência cotidiana (Q. 29, p. 2341).

Portanto, a linguagem pode expressar contradições (até porque a realidade é contraditória) e a partir de um conjunto de articulações é que ela pode ser entendida:

a) na sua relação com a estrutura da sociedade, na qual o simbólico se efetiva como expressão dessa mesma estrutura; a linguagem não é a essência que distingue o homem dos animais, mas os homens se produzem e se conhecem pela mediação do trabalho, fonte criadora da sociedade e do pensamento, cuja expressão se faz pela linguagem;

b) a linguagem é metafórica e, como tal, traduzível ou vinculada ao principio da conversibilidade, viabilizando a relação dos saberes entre si e destes com o real vivido. O uso de metáforas auxilia a esclarecer o significado de conceitos, na medida em que ele (o uso) se relaciona "ao mundo cultural, historicamente determinado, do qual surgiu", assim como se deve limitar historicamente a própria metáfora, a fim de impedir que se torne um instrumento mecânico de explicação. Dessa perspectiva, cabe "distinguir entre os dois fundadores da filosofia da praxis, cuja linguagem não tem a mesma origem cultural" de modo que suas metáforas "refletem interesses diversos" (Q. 11, p. 1474).

c) A partir desse contexto, qualquer expressão linguística tem seu conteúdo ideológico e seus efeitos políticos. Os significados se renovam a partir da relação histórica que se instaura entre uma comunidade e seu passado cultural. Daí a importância dos intelectuais no contexto de produção e reprodução das relações de dominação e a necessidade de tirar todas as consequências da afirmação de que "todos os homens são intelectuais" (Q. 13, p. 1516).

Desse modo, o problema não pode ser formulado a partir da lógica ${ }^{3}$, mas sim "nos termos de 'disciplina em relação à historicidade da língua'[...]”, a partir da qual se abordam os "erros gramaticais". Ou seja, "tudo o que (não) é 'gramaticalmente exato' pode ser justificado", tanto do ponto de vista lógico quanto estético ou histórico, se entendido não apenas da perspectiva de uma "lógica particular, de expressão imediatamente mecânica,

3 A propósito dos limites de uma abordagem abstrata, Gramsci tem uma anotação sobre o raciocinar pela média estatística e como esta forma de raciocínio pode deformar o conhecimento da realidade. "Neste caso é útil recordar a piada segundo a qual um Fulano faz duas refeições ao dia e Beltrano nenhuma; 'estatisticamente' Fulano e Beltrano fazem 'em média' uma refeição ao dia cada um. A deformação do pensamento originada pela estatística é muito mais difundida do que se acredita. Generalização abstrata, tem uma retomada continua do contato com a realidade (Q. 26, p. 2298). 
mas como elemento de uma representação mais vasta e compreensiva". A gramática é histórica, é "a 'fotografia' de uma determinada fase de uma língua nacional (coletiva), historicamente formada e em desenvolvimento contínuo". A questão central é política, ou seja, qual a função prática dessa fotografia: "fazer a história de um aspecto da civilização ou modificar um aspecto da civilização?" (Q. 29, p. 2341). Em outras palavras: conservar relações de hegemonia ou transformar a ordem vigente?

Esta nota que abre o Caderno 29, dedicado ao estudo da gramática, pode se explicitar quando se considera que a linguagem, assim como o senso comum, expressa elementos de uma concepção de mundo desarticulada, fruto de uma ação não acompanhada de uma teoria clara, compostos a partir da assimilação de informações desarticuladas e absorvidas sem crítica; tais elementos, mesmo quando não diretamente vinculados aos interesses políticos das classes dominantes, apresentam uma característica conservadora e estática porque são naturalizados, atuando para a aceitação do dado e a passividade ante o estabelecido.

Por outro lado, embora assimilem elementos desagregados e muitas vezes contraditórios em relação ao viver cotidiano, as classes subalternas possuem elementos embrionários que possibilitariam a formação de uma concepção própria de mundo, que poderiam assumir uma organicidade a partir de sua organização política.

Para efetuar a crítica da linguagem e demonstrar que o modo de pensar "não é independente e autônomo, mas submisso e subordinado", é necessário evidenciar a historicidade dos fatos e esclarecer os elos da ideologia com a infraestrutura. As ideias se radicam na estrutura da sociedade e, desse modo, apresentam dinamicidade e organicidade, atuando para conservar ou transformar o instituído. Importante salientar que, na medida em que se assume uma concepção de mundo emprestada, perde-se a voz e a autonomia de agir e de criar, de expressar as inovações da própria prática, de elevar esta prática ao mais alto nível de expressão teórica.

A linguagem, como o senso comum, difunde uma ideologia unificadora, que não mostra suas raízes históricas e de classe. Por isso, uma unidade política e cultural exige uma critica da linguagem e Gramsci se esmera nesse trabalho, enfrentando as teorias positivistas, pragmáticas, principalmente as ideias de Giovanni Vailati, seguidor de Peano e simpatizante de Russel e de Pierce, em torno da teoria do significado ${ }^{4}$. Enfrenta os defensores da tam-se de teorias filosóficas desde os antigos até os modernos, o que lhes garante uma certa ambiguidade, 
lógica abstrata, mostrando que a linguagem não é fixa nem imutável, mas histórica e metafórica, retirando seus significados do movimento da vida.

Creio poder dizer que a concepção de linguagem de Vailati e de outros pragmáticos não seja aceitável: entretanto, parece-me que eles perceberam as exigências reais e as "descreveram" com exatidão aproximativa, mesmo não conseguindo colocar os problemas e encontrar as soluções. Parece que se possa dizer que "linguagem" é essencialmente um nome coletivo, que não pressupõe uma coisa "única" nem no tempo nem no espaço. Linguagem significa também cultura e filosofia (ainda que a nível do senso comum) e, portanto, o fato "linguagem" é, na realidade, uma multiplicidade de fatos mais ou menos organicamente coerentes e coordenados: no limite se pode dizer que cada ser falante tem uma linguagem própria, ou seja, um modo próprio de pensar e de sentir (Q. 10, p. 1330).

A cultura unifica essas linguagens individuais em diversos graus, permitindo a comunicação ou o contato expressivo, ou seja, a "causa dos erros" não se encontra nas palavras, como querem os pragmáticos, mas no conteúdo ideológico que elas veiculam, na multiplicidade de sentidos que apresentam a partir das diferenças histórico-sociais, expressos nas diversidades culturais ${ }^{5}$. Os pragmáticos, e mais diretamente Pareto, procuram teoricamente as "causas de erro" na aplicação das palavras, como se a linguagem fosse estática quando, na verdade, ela se transforma no movimento de transformação da civilização e da cultura. A "linguagem é sempre metafórica”, principalmente em relação ao seu conteúdo ideológico construído ao longo da história; "toda a linguagem é um contínuo processo de metáforas, sendo a história da semântica um aspecto da história da cultura: a linguagem é um conjunto de coisas vivas e um museu de fósseis da vida e das civilizações passadas” (Q. 11, p. 1438).

Em linhas gerais, a questão da linguagem nos remete aos temas da cultura e da filosofia que, por sua vez, só podem se explicitar se enraizados na política. A linguagem se transforma no movimento histórico, com o surgimento de novas classes sociais e novas culturas. A linguagem pode não ser metafórica em relação ao objeto material que nomina, mas seguramente é

expressa em ensaios sobre temas ligados à questão da linguagem. Pode-se citar Pierce, mas também James e chegar a Dewey.

5 Assim como fez na crítica ao esperanto, no Caderno 3, a propósito de Lorianismo, Gramsci retoma a crítica de Pisani à teoria da monogênese de Trombetti, acentuando que a língua não se reduz ao puro léxico e que as palavras em línguas diferentes, mesmo com grafia igual, não apresentam o mesmo significado. As "formas lexicais e seus significados devem ser cotejados por fases históricas homogêneas das línguas em questão" e que, para cada forma, "é necessário 'fazer', além da história fonológica, a história semântica para cotejar com os significados mais antigos". O "parentesco de duas línguas não pode ser demonstrado pela comparação" de palavras, se faltam os argumentos gramaticais fonéticos, morfológicos e sintáticos (Q. 3, p. 408-9). 
metafórica em relação aos significados e conteúdos ideológicos que expressou em épocas anteriores; por isso, as palavras não podem ser abordadas como estáticas e verdadeiras de uma vez por todas, mas precisam ser entendidas dentro de um contexto crítico e histórico (Q. 11, p. 1438-1439).

Essa questão está presente já no Caderno 1, parágrafo 92, a propósito do americanismo, cuja força está em que "é uma filosofia que se afirma na ação", que modifica a realidade externa, ao contrário de outras filosofias que modificam apenas o "vocabulário e não as coisas" (Q. 1, p. 91). Essas "outras filosofias" possivelmente sejam o pragmatismo europeu, que difere basicamente do norte-americano na medida em que este se traduz em modo de vida, que modifica internamente o homem e a sociedade, enquanto o pragmatismo europeu, fruto de uma cultura arraigada na tradição elitista, não atinge a sociedade como um todo.

Essa questão é atual na medida em que uma das bases do chamado pós-modernismo se encontra na exaltação das estruturas da linguagem como constitutivas da essência humana, determinando as regras que orientam tanto a vida social e cultural quanto a identidade dos sujeitos. É certo que Gramsci não ignora essa dimensão da língua, mas reformula a proposição acentuando a sua historicidade e a sua importância no contexto das lutas de classes, retirando a linguagem de seu limbo metafísico para acentuar a sua dimensão política, ou seja, o modo como a linguagem se transforma em instrumento de poder no contexto das relações de hegemonia.

A luta de classes e a organização política dos trabalhadores se apresenta, para Gramsci, entre outros fatores, na necessidade de criticar o pragmatismo e seus efeitos políticos, desvelando o conteúdo ideológico de toda linguagem. A reflexão não se limita a discutir paradigmas, mas transita nos limites entre "filosófico" e "não-filosófico" para mostrar a importância de embasar a luta política na formação cultural, a fim de gerar as condições aos que "não sabem" de romper os elos da dominação e retomar a voz e a palavra elaborando o seu próprio pensamento.

Em termos práticos, essa questão se explicita na elaboração das políticas públicas para a educação e na possibilidade de acesso aos códigos de leitura e interpretação; por exemplo, ainda no Caderno 29, Gramsci pergunta quantas formas de gramática podem existir e reponde: muitas, pois toda forma expressiva traz implícita uma gramática que, em geral, não é considerada pelos neopragmáticos e os neolinguístas. A questão política é que as “manifestações 'espontâneas' de um conformismo gramatical” (na 
língua falada) é "desconexo, descontínuo, limitado a estratos sociais locais" (Q. 29, p. 2342-2343); a importância de uma gramática normativa escrita e ensinada na escola está no fato de ela possibilitar unificar as formas expressivas e abrir a possibilidade de uma crítica ao modo de pensar fragmentado.

O estudo da "gramática normativa escrita é sempre uma 'escolha', uma orientação cultural, ou seja, é sempre um ato de política cultural-nacional”. Em linhas gerais, depende das relações de hegemonia, da divisão social em classes e da separação entre dirigentes e dirigidos (Q. 29, p. 2344). Neste contexto, quem se propõe escrever uma gramática precisa ter clareza de sua "escolha", buscando "o centro de irradiação espontânea das inovações linguísticas”, inserindo-as de forma relativamente orgânica (Q. 29, p. 2344-2345).

Gramsci salienta os principais focos de irradiação das inovações linguísticas a serem considerados por quem escreve uma gramática: entre eles, a escola, os jornais, os escritores de arte e os populares, o teatro, o cinema, o rádio, as reuniões em geral, os relatos de experiências, as canções populares, etc., todos os elementos necessários para elaborar uma gramática histórica e/ou normativa enquanto expressão de uma língua unificada (Q. 29, p. 2345).

Para a formação dos trabalhadores, a gramática normativa escrita ensinada nas escolas é, portanto, de suma importância, porque abre a possibilidade de conhecer a língua de forma mais sistemática e de, dominando os códigos formais, dominar as formas argumentativas para elaborar um pensamento coerente e articulado, a fim de formar a sua própria identidade de classe. A importância da educação escolar se vincula à necessidade de construir as bases de luta política, necessárias para a formação de uma nova concepção de mundo. No caso do estudo da gramática normativa, Gramsci a compara ao estudo do latim nas escolas clássicas:

A gramática normativa, que somente por abstração pode ser considerada separadamente da linguagem viva, visa a fazer com que se aprenda todo o organismo de uma determinada língua, assim como ajuda a criar uma atitude espiritual que torne capazes de se orientarem num ambiente linguístico (Q. 29, p. 2349).

Quando um governo, na sua política educacional, decide retirar do currículo essa gramática como aconteceu com a Reforma Gentile, em $1923^{6}$, retira das classes populares a possibilidade de ter o aprendizado da língua

6 Esse tema abordaremos no capítulo sobre a educação. Um tema candente que, embora se refira, em Gramsci, ao contexto do fascismo italiano, serve para refletir sobre as nossas políticas educacionais. 
culta e de formular um pensamento coerente, ou seja, de ter acesso à produção cultural e ao conhecimento historicamente produzido. Na atitude de Gentile "há muito mais política do que se acredita", há "o reacionarismo da velha concepção liberal, há um 'deixar fazer, deixar passar' que não é justificado" (Q. 29, p. 2349).

Nesse contexto de leitura a crítica da linguagem e de seus efeitos políticos se apresenta como um dos momentos de elaboração do conceito de hegemonia enquanto forma de dominação que se sustenta na direção intelectual e moral, ou seja, na constituição e manutenção de uma elite de intelectuais capaz de elaborar um consenso ou de alimentar o senso comum com fragmentos de culturas mesclados com informações pretensamente neutras a fim de incentivar a aceitação do dado, a naturalização da história, a passividade ante o estabelecido, contribuindo para a estabilidade da prática social.

Essa questão se apresenta no próprio modo de escrever dos intelectuais, mostrando que a literatura é sempre perpassada por posicionamentos políticos. Gramsci o explicita no Caderno 14, a propósito da literatura popular e a relação entre conteúdo e forma: "existe uma diferença de estilos entre os escritos dedicados ao público e os outros, por exemplo entre as cartas e as obras literárias. Frequentemente parece que estamos diante de dois escritores diversos, tamanha é a diferença”. Nos escritos dedicados a poucos "predomina a sobriedade, a simplicidade", enquanto "nos outros escritos predomina a presunção, o estilo oratório, a hipocrisia estilística". Esta “[...]'doença' se encontra tão difundida" que foi assimilada pelo povo, para o qual “escrever” significa “[...]'fingir' um estilo redundante”, ou seja, “exprimir-se de um modo diferente do comum”. Daí se pode concluir que em uma determinada linguagem, o “[...]'conteúdo' indica um determinado modo de pensar, não somente histórico, mas ‘sóbrio', expressivo” (Q. 14, p. 1738).

Explicitar as relações de hegemonia implica mostrar que a linguagem radica-se na estrutura da sociedade, tem raízes histórico-sociais e, portanto, é ideológica e funciona como instrumento de poder e de dominação. No dizer de Edmundo Fernandes Dias, "construir a hegemonia pelos dominantes implica na destruição das formas culturais” vivenciadas pelas classes populares, processo que vai muito "além da pura incorporação de palavras ou expressões anglófilas”; passa pelo "apagamento de linguagens culturais”, produzindo um "horizonte ideológico" unificado que fundamenta o modo de pensar das classes subalternas (DIAS, 2012, p. 144). 
A linguagem é, pela formação do senso comum e por meio da fragmentação do pensamento ou pela divulgação de elementos dispersos e parciais, um dos mecanismos que escondem as desigualdades sociais e culturais naturalizando os fatos; mas pode ser ainda instrumento importante para a obtenção de uma nova unidade cultural, a partir da organização política dos trabalhadores e da superação do silêncio ao qual são reduzidos a partir da assimilação de uma linguagem. Somente a organização política permite superar as limitações culturais impostas pela hegemonia dominante, a partir da explicitação das contradições que permeiam o social e da formação de uma concepção crítica e coerente (Q.10, p. 1330-1331).

A linguagem expressa ou esconde um projeto de hegemonia. E todo movimento social de luta por uma nova ordem "cria uma linguagem própria, ou seja, participa no desenvolvimento geral de uma determinada língua” na medida em que introduz "novos termos, enriquece com novo conteúdo termos já em uso, cria metáforas", recorre a nomes históricos para facilitar a compreensão de determinadas situações políticas (Q. 29, p. 2264-2465).

Os Cadernos do Cárcere são ricos em análises de situações históricas (Reforma e Renascimento; Revolução Francesa, Risorgimento e função dos Moderados e do Partido da Ação, entre outros), as quais servem como aprendizagem do encaminhamento das lutas, de como a hegemonia dominante se constrói, das formas de subalternidade que se consolidam. Daí a importância de superar as formas de analfabetismo e ampliar as possibilidades de formação dos trabalhadores, a importância da leitura dos clássicos da literatura, a necessidade de a Itália criar condições de formação de uma linguagem nacional-popular. É na medida em que um movimento político se organiza e envolve as massas criando condições de intervenção política que as palavras assumem novos sentidos, apontam novas direções e o pensamento esclarece o significado das práticas, permite uma visão de conjunto que evidencia as forças em presença e os encaminhamentos possíveis.

Elaborar a própria concepção de mundo significa reconhecer-se como classe, criar uma identidade de classe, assim como a consciência de si e dos objetivos a alcançar. "A compreensão de si mesmo, a luta entre o antigo e o novo, a luta pela hegemonia consiste (também) em se situar na linguagem, posto que a própria linguagem, através de um meio social, nos situa aí como sujeitos" (BUCI-GLUCKSMANN, 1980, p. 460). Essa questão é fundamental na luta pela hegemonia: a linguagem é o instrumento de unificação política e cultural de uma classe, bem como da formação de sujeitos 
autônomos que reconhecem os limites e possibilidades de sua ação. Com o desenvolvimento do capitalismo financeiro em âmbito internacional, com a inserção das novas tecnologias de produção e comunicação, a hegemonia e a luta de classes assumem uma nova dimensão que é cultural e simbólica, fortalecendo e sustentando as relações econômicas e suas novas formas de dominação e exploração da força de trabalho.

\section{A dimensão simbólica no contexto das lutas de classes}

Se o político é um historiador, o historiador é também um político $e$, neste sentido, a história é sempre história contemporânea $(Q$. $10, p .1242)$.

$\mathrm{O}$ fato de concentrar-se em uma dimensão do humano sem considerar os elos sociais, políticos e culturais produzidos no contexto da sociedade moderna a partir do modo como se organizam as relações de trabalho não seria um sintoma de uma opção política? Certamente, a valorização da linguagem como básica na formação da essência humana tem um significado político e ideológico que se esclarece apenas se tiver como pressuposto à estrutura da sociedade moderna fundada na divisão social do trabalho e na exploração da força de trabalho.

Trata-se de superar a visão dualista que separa pensamento de ação e que Gramsci aprofunda ao explicitar o significado de filosofia da praxis: no Caderno 10, Gramsci retoma uma expressão de Bacon quando diz que "o conhecimento é poder", na medida em que "o homem não entra em relações com a natureza pelo simples fato de ser ele natureza”, mas sim "por meio do trabalho e da técnica". Tais relações "são ativas e conscientes" e, por meio delas, "cada um transforma a si mesmo, se modifica, na medida em que transforma e modifica todo o conjunto de relações do qual se faz parte"; ter consciência dessas relações ou conhecer a realidade na qual se vive significa "conhecer mais ou menos o modo pelo qual (a realidade) pode se modificar” e esse processo de conhecimento "já as modifica. As próprias relações necessárias, na medida em que são conhecidas em sua necessidade, mudam de aspecto e de importância” (Q. 10, p. 1345). Para as classes subalternas o conhecimento se adquire no movimento de organização política pelo qual, na medida em que se age, se conhece e se altera a realidade na qual se está inserido.

A luta de classes supõe cada dia com mais intensidade a criação de uma autonomia intelectual das classes subalternas que implica o domínio 
da linguagem ou a elaboração de uma linguagem própria. No contexto da sociedade tecnológica e dos meios de comunicação de massa, o poder da linguagem transcende todos os antigos limites. Pier Paolo Pasolini, leitor de Gramsci e estudioso da linguagem, em artigo de 1968, ao ser perguntado por que os intelectuais, em geral, não colaboram com programas televisivos, alerta para o poder autoritário e incondicional da televisão: primeiro, porque "entre vídeo e expectador não há possibilidade de diálogo. O vídeo é uma cátedra" que "consagra, dá autoridade, oficialidade". Segundo, porque "o vídeo representa a opinião e a vontade de uma única fonte de informação, que é precisamente - de modo genérico - a do Poder. E, desse modo, mantém o expectador submisso". O que quer que se diga, entra em um universo de relações de poder e de informações centralizadas e manipuladas conforme os interesses da emissora e de quem a financia e não no interesse da informação efetiva. "Por essas razões", completa Pasolini, "é claro que um intelectual, teoricamente, só pode dizer 'não' à televisão” (PASOLINI, 1982, p. 97-98).

Essas observações feitas no final da década de 60 tomam dimensões inusitadas se pensarmos na mundialização $0^{7}$ do capital, na reforma neoliberal dos Estados e nas novas configurações da telemática no início do século XXI, com uma concentração mundial da propriedade privada dos meios de comunicação de massa nas mãos de poucas famílias. Os meios de comunicação em geral, cinema e televisão à frente, "realizam uma poderosa ação transformista, absolutamente necessária à Ordem, de conversão do desejo em necessidade" (DIAS, 2012, p. 145). Necessidades supérfluas que são apresentadas como meios de realização da felicidade formando o imaginário de uma sociedade carente que se alimenta do sonho de ascensão social para usufruir dos bens do sistema produtivo. Pasolini acentuava que a televisão "é o lugar onde se torna concreta uma mentalidade que de outro modo não acharia onde colocar-se. É através do espírito da televisão que se manifesta o espírito do novo poder" econômico e político, na forma mais “autoritária e repressiva” de formação do consenso (PASOLINI, 1979, p. 31-32).

Antonio Gramsci acentuava como um consenso passivo funciona no contexto da consolidação da hegemonia e já se preocupava com a atuação dos jornais na formação da opinião pública, determinando os caminhos de um

\footnotetext{
7 Retomando as reflexões de Lea Durante (2000/2001, p. 86), entende-se mundialização como a "atual fase de expansão transnacional da economia" que, em sua "dimensão ideológica", se traduz na "transferência dos poderes reais e da hegemonia dos Estados para as empresas. A partir desse esquema se estrutura uma série de corolários, como a positividade da divisão internacional do trabalho como fator de progresso para as áreas menos desenvolvidas, a esperança de um reconhecimento cada vez mais amplo dos direitos civis e assim por diante".
} 
processo eleitoral ou de uma política. Na luta pela hegemonia a linguagem é um instrumento de unificação de uma vontade nacional e esse trabalho é feito pelos intelectuais. A tendência a formar uma elite distante do povo dificulta, para as classes dominantes, manter a hegemonia. Em geral, com o desenvolvimento do capitalismo e com a subordinação dos agentes de comunicação às empresas que os empregam, resolveu-se em grande parte o problema. A produção de um mercado de consumo de cultura de massa (cinema, novelas, best-sellers, etc.) sedimenta a hegemonia a partir da formação de um pensamento homogêneo, que se traduz em comportamentos adequados aos objetivos da hegemonia. Gramsci o descrevia da seguinte forma:

Quando a concepção do mundo não é crítica e coerente, mas ocasional e desagregada, pertencemos simultaneamente a uma multiplicidade de homens-massa, nossa própria personalidade é composta de maneira bizarra: nela se encontram elementos dos homens das cavernas e princípios da ciência mais moderna e progressista; [...]. Criticar a própria concepção de mundo significa torná-la unitária e coerente e elevá-la até o ponto atingido pelo pensamento mundial mais desenvolvido (Q. 10, p. 1376).

Superar a fragmentação e as contradições da própria concepção do mundo e elaborar uma consciência crítica só pode ser efetuado em grupo, num movimento de organização política, com projetos sociais definidos, processo que passa pela ressignificação da linguagem e aprofundamento do conhecimento da língua nacional. Mesmo quando se assimila a concepção do mundo hegemônica, se possui uma "concepção própria do mundo, ainda que embrionária, que se manifesta na ação e, portanto, descontínua e ocasionalmente". Enquanto não se desvela o embrionário, fato que só pode ocorrer num movimento político organizado, o subalterno "toma emprestada a outro grupo social, por razões de submissão e de subordinação intelectual, uma concepção do mundo que lhe é estranha”, ou seja, que não expressa o seu cotidiano e seus interesses de grupo (Q. 10, p. 1379).

Essa questão torna-se fundamental, porque a fragilidade dos vencidos se determina pelo fato de que não possuem uma concepção do mundo bem elaborada, que expresse seus interesses e suas práticas de classe. Daí a importância da cultura e da educação, bem como da atuação dos intelectuais no contexto do pensamento de Gramsci.

Cabe acentuar que, embora os meios de comunicação de massa consolidem um pensamento homogêneo, um consenso total e cristalizado não existe e a sociedade, em qualquer momento histórico, a bem dizer, vive 
diferenças ideológicas e visões conflitantes da realidade, que tomam proporções de enfrentamento e de tensão profunda conforme os movimentos de organização política das classes subalternas. É nos momentos de crise econômica e política que as contradições emergem e os conflitos podem tomar proporções radicais, levando a situações em que um consenso se torna impossível.

Gramsci acentua que o que se apresenta na forma da língua ou da linguagem é a aparência sob a qual se escondem outros problemas de fundo, como a necessidade de "formação e ampliação da classe dirigente, a necessidade de estabelecer relações mais próximas e seguras entre os grupos dirigentes e a massa popular-nacional, ou seja, de reorganizar a hegemonia cultural" (Q. 29, p. 2346).

Um dos mecanismos de aprendizagem da língua que Gramsci considera essencialmente político é a gramática normativa, que precisa ser colocada em relação com a gramática histórica, que são distintas, mas que, como a política e a história, não podem ser pensadas separadamente:

Posto que a gramática normativa é um ato político e que somente partindo deste ponto de vista se pode justificar "cientificamente" a sua existência, que enorme trabalho de paciência requer a sua aprendizagem, (quanto trabalho se faz necessário para conseguir que centenas de milhares de jovens das mais diferentes origens e preparação mental se tornem um exército homogêneo e capaz de mover-se e agir disciplinada e simultaneamente: quantas 'lições práticas e teóricas' de regulamentos, etc.) deve-se perguntar de sua relação com a gramática histórica (Q. 29, p. 2347).

O estudo das línguas apresenta-se como um fenômeno cultural, enquanto formação que se faz na vida e não apenas na escola, passa pelo transformismo e pela negação ou apagamento das culturas das classes populares, que assimilam gradativamente o modo de ser e pensar hegemônicos veiculados pelos meios de comunicação de massa. Uma vez apagadas ou esquecidas, as culturas tradicionais e todos os seus ensinamentos, em geral fruto da memória dos mais velhos e da transmissão oral, perdem-se para sempre.

Pasolini acentua, em seus Escritos Corsários, que a cultura se constitui do conjunto de todas as culturas de classe, num texto que lembra o que Gramsci nos diz sobre a filosofia:

O que é a cultura de uma nação? Pensa-se geralmente, mesmo entre a gente culta, que é a cultura dos cientistas, dos políticos, dos professores, dos literatos, dos cineastas, etc., isto é, a cultura da intelligentsia. No 
entanto, isso não é verdade. E também não é a cultura da classe no Poder, que, justamente através da luta de classes, tenta impô-la pelo menos formalmente. Finalmente, também não é a cultura da classe oprimida, ou seja, a cultura popular dos operários e camponeses. A cultura de uma nação é o conjunto de todas estas culturas de classe: é a sua média. E seria, pois, abstrata se não fosse reconhecível - ou antes, visível - no vivido e no existencial, e se não tivesse por consequência uma dimensão prática (PASOLINI, 1979, p. 55 - grifo do autor).

Essa definição de cultura de Pasolini nos lembra as observações de Gramsci sobre a filosofia de uma época e, poderíamos ainda dizer, a linguagem de um tempo: não existe uma filosofia, mas filosofias e sempre se escolhe uma entre elas, assim como existem várias linguagens, num movimento contraditório de produção e reprodução do pensamento vinculado a determinadas práticas, as quais formam um modo de pensar e de sentir.

Essa diversidade, porém, com as novas tecnologias de comunicação, parece estar com os dias contados. Pasolini, já na década de 1970, alertava para um novo tipo de centralismo, que supera imensamente a proposta fascista consolidada na Itália, que se traduz na formação da sociedade de consumo como um novo fenômeno cultural que unifica a partir da veiculação da ideologia que sustenta a sociedade capitalista. A ideologia se apresenta na falsa imagem da tolerância e no conformismo que, no fundo, têm traços profundamente repressivos, no modo como os meios de comunicação de massa reduzem todos "ao normal e conformista como o consumidor"; os condicionamentos se produzem por uma postura pretensamente democrática, mas profundamente autoritária, como via de mão única que não possibilita diálogo ou confronto (PASOLINI, 1979, p. 56-57).

Essa ideologia se faz acompanhar pelo hedonismo, que esconde a "determinação de planear tudo com uma desumanidade tal como a história jamais tinha conhecido até agora”. Esse novo Poder tem expressão na formalização dos códigos de comunicação e na formação de um comportamento unificado, "num momento da história em que a linguagem verbal é completamente convencional e esterilizada (tecnicizada), a linguagem do comportamento (corporal e mímico) assume uma importância decisiva”. Escrito em 1974, o artigo parece prenunciar a formação de um pensamento único, a produzir-se pela atuação dos meios de comunicação de massa, que veiculam uma linguagem corporal acompanhada de uma linguagem verbal "completamente reduzida a convenções e extremamente pobre" (PASOLINI, 1979, p. 56-57). Assistir a qualquer programa da televisão brasileira quase cinco décadas depois confirma esse prognóstico. 
Raul Mordenti (2007, p. 18) vai mais longe ao explicitar a inversão realizada pelos meios de comunicação de massa, concretizando o que Marx descreve no primeiro livro de $O$ Capital como fetichismo da mercadoria: "um programa televisivo não é produzido para ser vendido ao público, mas sim produzido para vender o próprio público para as empresas publicitárias". Desse modo, o público, de sujeito passivo "do mecanismo de compra e venda, torna-se o seu objeto". Com efeito, "é precisamente a presença de uma tal mercadoria, o público, que determina sob a base dos índices de audiência os valores dos espaços publicitários que financiam os programas" e permitem a acumulação de enormes lucros dos proprietários das redes televisivas. "As consequências dessa inversão são politicamente decisivas".

Mordenti (2007, p. 18) acentua ainda que essa inversão tem um efeito deformante sobre o modo como se veicula o "sentido das coisas", sobre "a possibilidade dos homens e mulheres de pensar juntos e de trocar entre si experiências e saberes". Isso porque a "publicidade prescinde (e deve prescindir) da pretensa verdade das coisas", sendo essa a "modalidade dominante e absolutamente penetrante da cultura contemporânea", de modo que a "própria cultura sofre uma redução rigorosa à comunicação", sendo que esta "não comunica nada mais senão a si mesma" tornando-se o parâmetro da verdade. Vivemos uma época que suprime o sentido das coisas e cria seus próprios sentidos em função dos interesses do capital: a felicidade se resume em beber um refrigerante; os desejos e necessidades se reduzem a comprar o último celular em moda, etc.

Conforme Dias (2012, p. 145), a televisão tem, em geral, uma função "conservadora quando não abertamente reacionária. Seu mote é a despolitização ou a politização favorável aos dominantes”. O domínio econômico no contexto da globalização se firma e se consolida no domínio político e ideológico, concentrado na "fusão das potências midiáticas" (DIAS, 2012, p. 146). Nesse horizonte no qual se forma o imaginário do cidadão expectador dócil e passivo, a força da linguagem, verbal e imagética, reduz as classes populares a um saber superficial e fragmentado que constitui seu senso comum e destrói todas as suas possibilidades de resistência.

Os caminhos de transformação dessa realidade passam pela apropriação dos mecanismos de direção cultural, de formação intelectual e moral da sociedade, colocando em evidência a educação no contexto das relações de hegemonia. Se pensarmos nos altos índices de analfabetismo entre as classes populares em âmbito mundial e nas dificuldades de estabelecer a relação entre alfabetização e letramento, enquanto domínio efetivo dos 
mecanismos de conhecimento, podemos formar uma ideia da extensão do problema. Mais do que na aurora do capitalismo, quando da formulação de Bacon de que "o conhecimento é poder", essa assertiva se tornou real no capitalismo contemporâneo: fala-se muito em "sociedade do conhecimento" e nunca como nesse início de século houve uma concentração tão grande do conhecimento em poucas mãos, instrumento de domínio econômico, social e político, de manutenção das formas mais antigas de dominação e de consolidação de novas formas de subordinação que passam pela formação da subjetividade na assimilação de um pensamento homogêneo.

Nesse contexto é que se inserem os termos gramscianos "subalterno" e "subalternidade": subalterno é o indivíduo dominado, mesmo sem ter consciência disso porque vive em um contexto de extrema alienação. Essa alienação se institui, como afirmava Marx, a partir das relações de trabalho, estendendo-se ao conjunto das relações sociais e modos de vida; uma situação garantida pela veiculação de ideias como "democracia" que, na forma da alternância de grupos ou indivíduos no poder, ou seja, na sua ambiguidade, gera a crença de participação igual garantida pela lei. A formalidade da lei extensiva a todos dissolve ou esconde o antagonismo de classes fundado na desigualdade econômica e na exploração do trabalho, esconde a realidade na qual as desigualdades se aprofundam na medida da concentração do capital e da renovação permanente do capitalismo.

A subalternidade se produz tanto no contexto da exploração do trabalho já analisada por Marx em $O$ Capital, onde esclarece, entre outras coisas, como o contrato de trabalho fundado na ideia de "liberdade igual dos contratantes" oculta o processo de exploração que se instaura a partir da compra da força de trabalho, identificada no cotidiano numa experiência sui generis, no qual o comprador da força de trabalho, o capitalista, vai à frente, com seu ar altaneiro "sorriso velhaco e ávido de negócios”, enquanto o trabalhador o segue cabisbaixo, "tímido, contrafeito, como alguém que vendeu sua própria pele e apenas espera ser esfolado” (MARX, 1980, p. 197).

A subalternidade produzida a partir da estrutura do modo de produção capitalista estende-se a todas as outras instâncias da vida social e se consolida na contemporaneidade com o fortalecimento dos meios de comunicação de massa, na formação de um consenso passivo. A inversão que se caracteriza no modo como a forma mercadoria torna possível que uma "relação social definida, estabelecida entre os homens, assuma a forma fantasmagórica de uma relação entre coisas" e estende-se ao modo de pensar e de ser dos indivíduos (MARX,1980, p. 81). 
Vivemos uma época na qual, no dizer de Mordenti (2007, p. 18) ocorre "uma perfeita inversão do sentido das palavras e das coisas", ou ainda esclarecendo, de "supressão do sentido das coisas", gerando naqueles que se apercebem da situação, uma sensação de permanente absurdo. Essa confusão generalizada de posições, de sentidos, o esmaecimento de valores historicamente consolidados, a fragmentação do conhecimento, a valorização do especialista, as palavras que designam o aparente e cotidiano, tudo concorre para a consolidação das formas de subalternidade que se reproduzem em apatia política e inação, sem condições de, ao menos, indignar-se ante o que se veicula nos meios de comunicação.

A possibilidade de um projeto econômico e social alternativo, de uma democracia efetiva e não apenas formal, se encontra na capacidade das classes trabalhadoras de se organizarem e efetivarem a sua capacidade de luta, superando as condições de subalternidade existentes, entre elas as que se consolidam no sentido abstrato de determinadas palavras como "liberdade", democracia", "paz", etc ${ }^{8}$.

A palavra "liberdade", por exemplo, tomada no cotidiano na sua forma abstrata e mais comum de escolha entre determinadas opções, conforme a vontade individual e as características da natureza humana; nessa abordagem, ignora-se que essa liberdade é determinada pelas condições sociais e políticas que fundam a formação e a vida de cada indivíduo; ignora-se ainda um pressuposto fundamental da modernidade, que consiste em que a liberdade se define a partir da base jurídica que caracteriza o pensamento moderno, com o objetivo de garantir formalmente direitos subjetivos. Cabe explicitar que o formal não expressa o real, visto que este se constitui por uma situação de desigualdade historicamente instituída, com base na exploração da força de trabalho e sua consolidação na estrutura capitalista de produção.

O mesmo pode-se dizer de outras palavras tomadas no seu sentido imediato e cotidiano. Tomar as palavras em sua radicalidade significa fazer o traçado de sua história, o que implica, para as classes trabalhadoras,

8 Trata-se de uma inversão que obnubila a consciência das massas populares e enreda as classes subalternas na teia do direito instituído, que as leva a naufragar no reformismo. O direito, tomado como norma neutra e válida para todos os indivíduos indiscriminadamente dilui as características fundamentais da luta de classes. Como acentua Edelman (2016, p. 72) a "violência tornou-se uma relação jurídica, a luta de classes tornou-se um conflito de direitos e as próprias classes tornaram-se sujeitos de direito, cada uma por si própria, detentora de 'seu' direito. De um lado, o empregador é sujeito do direito de propriedade; de outro, os operários são sujeitos do direito do trabalho. Consequentemente, a relação capital/trabalho transformou-se numa relação jurídica entre direito de propriedade e direito de trabalho". Os pressupostos que sustentam o direito não são questionados. 
elaborar sua própria concepção de mundo, ou seja, um modo de pensar que coincida com o sentir, que permita entender, explicitar e superar as contradições vividas e fazer a crítica ao modo de pensar hegemônico. Implica afirmar sua identidade de classe, o que só é possível, na leitura de Gramsci, a partir de seu empenho na sua organização política.

\section{A linguagem como metáfora e a afirmação da identidade dos subalternos}

Toda a linguagem é um contínuo processo de metáforas, sendo a história da semântica um aspecto da história da cultura: a linguagem é, simultaneamente, uma coisa viva e um museu de fósseis da vida e das civilizações (Q. 11, p. 1438).

Retomamos agora o item b, que acentua que a linguagem é metafórica por ser um produto histórico e, como tal, inserido no conjunto de relações de forças que instituem e consolidam a ordem social ou o poder. Ser metafórica significa que possui vários sentidos que se entrecruzam, ou seja, é ambígua e dinâmica, podendo ser instrumentalizada conforme os interesses políticos em presença. Por outro lado, o ambíguo pode ser ainda aquilo que escapa à lógica e à coerência do sistema, aquilo que é inusitado, que gera perplexidade e pode, por suas características, colocar em questão toda a ordem instituída. Como se entende a partir do materialismo histórico, a realidade não é translúcida e o imediatamente dado, que aparece como o lado luminoso das relações sociais, esconde as contradições que o compõe e que precisam ser desveladas para que seu verdadeiro conteúdo (político, ideológico) transpareça.

Na medida em que se afirma o novo modo de existência da filosofia pela sua relação privilegiada com a história e a política, característica fundamental do materialismo histórico, tem-se que reconhecer a historicidade de toda concepção de mundo e as novas articulações que se estabelecem entre sujeito e objeto, consciência e realidade, conhecimento de si e do mundo. Tem-se ainda que assumir a metáfora como o modo de expressão privilegiado do discurso filosófico, vinculando-a aos princípios de tradutibilidade e conversibilidade. Uma definição de metáfora que encontramos no Caderno 11 afirma o seguinte: "pode-se dizer que a linguagem atual é metafórica com relação aos significados e ao conteúdo ideológico que as palavras tiveram nos períodos precedentes da civilização”. Não considerar esse fato, ou seja, do fato de "não se ter um conceito crítico e historicista 
do fenômeno linguístico derivam muitos erros, seja no campo da ciência quanto no campo prático" (Q. 11, p. 1427).

Nesse contexto, são as palavras e as linguagens traduzíveis e conversíveis, de modo que os pragmáticos erram ao "teorizar abstratamente sobre a linguagem como causa de erro" (G. PARETO, G. PREZZOLINI). A "linguagem se transforma com o transformar-se de toda civilização", com as mudanças culturais, com "a hegemonia exercida de uma língua nacional sobre outras, etc.” (Q. 11, p. 1427).

A tradutibilidade ocorre entre línguas e entre a linguagem e a prática; na luta por uma nova hegemonia cria-se também uma nova linguagem, pois ela é viva e traduz o movimento da realidade vivida. Uma filosofia que se manifesta como reflexão sobre a atividade humana e tem como objetivo precípuo a transformação dessa realidade, pode nascer de práticas não filosóficas e pode ainda converter-se em ação efetiva, ou seja, não pode ser formalizada, mas apenas traduzida.

Todo movimento cultural cria a sua linguagem própria, ou seja, participa no desenvolvimento geral de uma determinada língua nacional, introduzindo termos novos, enriquecendo com conteúdo novo os termos já em uso, criando metáforas, servindo-se de nomes históricos para facilitar a compreensão e o juízo sobre determinadas situações (políticas) atuais (Q. 29, p. 2264-2265).

A tradutibilidade designa a possibilidade de relação dos saberes entre si e destes com a atividade prática; se a filosofia, a política e a economia "são elementos constitutivos de uma mesma concepção de mundo, deve existir necessariamente, em seus princípios teóricos, conversibilidade de uma na outra, tradução recíproca na linguagem especifica de cada uma” (Q. 11, p. 1492-3). Esses saberes não são meros reflexos da infraestrutura, mas são traduzíveis entre si e apresentam uma conversibilidade com a prática, numa relação não redutora, mas produtiva, eficaz, transformadora. É a partir desse contexto que as classes subalternas podem, a partir de sua organização política e de sua linguagem própria, apropriar-se da cultura ou do conhecimento historicamente produzido, a fim de construir projetos transformadores da estrutura econômica, social e política.

Conforme Lacorte (2014, p. 61), a tradução entre linguagens "implica um trabalho político, no sentido amplo desta palavra, ou seja: um trabalho pedagógico-cultural, que se insere no quadro da transformação política da sociedade”. Para Gramsci, trata-se de explicitar a articulação entre teoria 
e prática a partir da leitura de Marx e de Lenin ${ }^{9}$, fazendo a crítica aos dois revisionismos que atingiram a filosofia da praxis: o determinismo mecanicista e o neoidealismo kantiano.

No curso dos Cadernos descortina-se uma metodologia histórica que explicita os fundamentos da dialética materialista e a relação concreta entre teoria e prática, a partir da qual a filosofia da praxis pode absorver outros paradigmas menores, como a filologia ou a linguística histórica.

Para Gramsci o materialismo histórico apresenta-se como a filosofia que, por ser "expressão necessária e inseparável de uma determinada ação histórica” (Q. 11, p. 1401-1402), por ser vivida na prática enquanto concepção de mundo, pelo seu compromisso com a transformação da realidade, por sua eficácia histórica, pode ser traduzida nas "linguagens das situações concretas particulares” e o movimento operário alemão pode ser apresentado como o "herdeiro da filosofia clássica alemã", um herdeiro que "continua praticamente o predecessor", porque "deduziu uma vontade ativa, transformadora do mundo, da mera contemplação” (Q 11, p. 1472-1473 e 1272) ${ }^{10}$. É somente nesse movimento relacional dialético entre teoria e prática que o conhecimento se realiza.

Na luta pela hegemonia, a questão do conhecimento e da linguagem são fundamentais para a conquista da direção intelectual e moral da sociedade. Daí a força hegemônica que emana do controle dos meios de comunicação de massa e da formação de um consenso passivo; no contexto da mundialização do capital e da fusão das grandes potências midiáticas, o controle autoritário e imperialista se instaura de modo sutil e quase imperceptível. Desconstruir esse processo e gerar novas bases de reflexão ou uma nova concepção de mundo torna-se um desafio como o de Sísifo ante a montanha ou de Édipo ante a esfinge.

E desconstruir implica seguir a senda de Marx, que partiu do contexto teórico produzido por economistas e filósofos da época para elaborar uma nova teoria crítica e transformadora. Nas aparências conciliadoras, Marx

9 Como exemplos, em Marx Gramsci salienta a relação efetuada entre a filosofia clássica alemã e a Revolução Francesa (Sagrada Família) e, em Lenin, a relação entre política e filosofia (um político escreve um livro de filosofia, mas a sua filosofia deve ser procurada na sua ação e nos seus escritos políticos).

10 No já citado Caderno 11, Gramsci (1978, p. 1471) retoma o curso da análise filológica de Croce sobre a comparação entre a linguagem política francesa e a linguagem filosófica alemã contida em A Sagrada Família; acentua que a expressão de Carducci: "Kant decapitou Deus - Robespierre, o Rei” foi retomada de Heine, mas a expressão original coube a Hegel em suas aulas de História da Filosofia e de Filosofia da História; nessas aulas, Hegel disse que "as filosofias de Kant, Fichte e Schelling continham a revolução em forma de pensamento" e que "somente os alemães e os franceses, por opostos que sejam entre si, ou precisamente porque opostos", conseguiram alcançar um grande momento da história universal. 
identificou as contradições; no contexto ideológico dominante, identificou os limites dos discursos e os interesses práticos que os sustentavam; destacou categorias e apropriou-se de conceitos para mostrar seus limites e superá-los a partir de sua articulação com a realidade efetiva. A partir de seu trabalho, transforma-se a filosofia e a teoria política para abrir novos horizontes de transformação.

Gramsci seguiu como ninguém essa senda, para mostrar que, no contexto das relações de hegemonia e da correlação de forças que caracteriza a luta de classes, esta se renova na medida em que o conhecimento se transforma em instrumento de dominação; o fato de a linguagem ser metafórica permite ressignificar as palavras conforme o momento histórico e a relação de forças em presença, ou seja, assim como os dominantes instrumentalizam a linguagem e a cultura para fins do exercício do poder, a organização política das classes subalternas se apresenta como o meio para elaborar a sua concepção de mundo, a sua cultura e a sua linguagem para assim se apropriar do conhecimento historicamente produzido. Sabe-se que se trata de uma relação extremamente desigual, mas a criação de formas de resistência não é impossível.

O possível precisa ser construído a partir da leitura crítica das condições presentes, ou seja, “do ponto de vista dos subalternos é necessário fazer a crítica da economia e da política burguesas, atuar no sentido da invenção da sociabilidade socialista" a partir da explicitação das condições presentes (DIAS, 2012, p. 133-134). Ou seja, inventar no interior da ação e do discurso burguês, rompendo os elos de subalternidade, criando uma linguagem própria, tirando proveito das possibilidades metafóricas a fim de refutar com destreza o universal legitimador do pensamento único e retomar o conhecimento na sua dimensão histórica.

Por exemplo, quando se fala em luta de classes tem-se que explicitar que o seu significado se transformou com a mundialização do capital: a luta de classes toma novas dimensões no contexto do capitalismo a partir do modo como se produzem e reproduzem as classes no movimento de produção dos modos de vida. Como acentua Dias, as classes "não são uma classificação topológica, mas articulações de luta, experiências e sociabilidades produzidas conflitivamente na sua oposição estrutural” (DIAS, 2012, p. 159). Nesse processo os "meios de comunicação de massa tornam-se decisivos na disputa hegemônica, alterando fundamentalmente o processo de luta de classes" (DIAS, 2012, p. 118). As formas de dominação se consolidam com base na 
formação de um modo de pensar homogêneo e pretensamente universal, diluindo as condições de expressão das classes subalternas.

Precisamos ter clareza de que "o real não é translúcido, não se revela ao puro olhar do investigador" (DIAS, 2007, p. 35), como querem fazer crer as tendências pós-modernas, concentradas no cotidiano e valorizando os relatos de experiência. $\mathrm{O}$ que nos aparece de imediato é sempre a ponta de um iceberg, uma imagem que oculta os elementos essenciais para a explicitação de seu significado. Para conhecer precisamos mergulhar nas aparências e buscar o que nelas se esconde; a verdade não se encontra em uma perspectiva, mas no verso e reverso da tessitura social, no visível que oculta o invisível, a forma e o conteúdo, a superfície e o abismo, num jogo de luzes e sombras.

Iluminar, para além das aparências, as contradições e as formas que elas assumem no processo de construção das condições materiais de existência, assim como as formas que assume a ideologia como prática de poder, supõe a organização política dos trabalhadores a fim de superar todas as ilusões e transformismos que minam já na origem qualquer tentativa de resistência frente aos mecanismos de poder. Trata-se de criar, nos embates políticos, as possibilidades de uma nova cultura e uma nova linguagem que possibilitem romper os elos de subordinação e as formas de marginalização que se proliferam na sociedade capitalista.

A questão que novamente se coloca nesses tempos de neoliberalismo é, na mesma assertiva que Jameson colocou para Lukács a proposito de História e Consciência de Classe, agora estendida para a esquerda: "mostrar que o pensamento proletário é exatamente capaz de resolver as antinomias que o pensamento burguês, pela sua própria natureza, é incapaz de enfrentar" (JAMESON, 1985, p. 146) ${ }^{11}$. E essa incapacidade do pensamento burguês se apresenta precisamente como limite ideológico ${ }^{12}$ na separação entre sujeito

11 A questão de fundo da leitura de Lukács, conforme Jameson (1985, p. 146) é mostrar como "alguma coisa na estrutura mesma do pensamento proletário dá acesso à totalidade ou realidade, ao conhecimento totalizante que era a pedra no caminho da filosofia burguesa clássica, com a resultante substituição do modelo estático de conhecimento, modelo do qual brotam os dilemas da burguesia. Algo deve ser encontrado na própria situação existencial do operário, que corresponda, como realidade concreta àquela união de sujeito e objeto, de conhecedor e conhecido, que Hegel propôs como solução ao problema kantiano da coisa-em-si no domínio do pensamento puro".

12 Lembramos A crítica de Marx a Hegel em O 18 Brumário de Luiz Bonaparte: "Hegel observa em uma de suas obras que todos os fatos e personagens de grande importância na história do mundo ocorrem, por assim dizer, duas vezes. Esqueceu-se de acrescentar: a primeira como tragédia e a segunda como farsa" (MARX, 1977, p. 17). O "esquecimento" de Hegel demonstra os limites da filosofia idealista e sua impossibilidade de conceber o movimento histórico real em suas contradições. Do mesmo modo, pode-se identificar o "esquecimento" de Ricardo que, nos limites da economia política que fundava suas reflexões, não podia falar da mais-valia. 
e objeto, na abordagem parcial e estática da história e da cultura limitada pelo pensamento abstrato, em todas as formas que assume, principalmente na valorização da linguagem em si, sem a sua devida articulação com a política. O problema de fundo é o de como colocar, no âmbito do historicismo, a questão da universalidade: somente o trabalhador, ao viver a condição de objeto e ao perceber-se como tal pode elaborar uma nova consciência de si que seja também uma consciência de classe, a partir da apreensão do real como processo e da unidade de pensamento e ação. Somente assim é possível compreender o real para além de suas aparências, o que implica uma efetiva organização política e a reformulação do entendimento sobre o processo pedagógico.

\section{Linguagem, concepção de mundo: a formação dos subalternos}

Nos períodos de crise, verificam-se as mais extensas e múltiplas manifestações de neolalismo (GRAMSCI, 1978, p. 2193).

A historicidade da linguagem e sua dimensão política que apresenta nas possibilidades de comunicação a partir da sua característica metafórica e como, a partir desse contexto, se pode construir a identidade dos subalternos. O materialismo histórico apresenta-se como uma nova filosofia que possui as condições de fazer a tradutibilidade das línguas, que designa a possibilidade de relação dos saberes entre si e destes com a realidade a partir do modo como entende a relação teoria e prática.

Iniciamos acentuando que Gramsci considera as mais variadas expressões da linguagem: falada e escrita e das artes em geral (música, pintura, arquitetura, etc.); o teatro apresenta-se como uma forma privilegiada de arte, porque alia várias linguagens expressivas (gesto, música, palavra, dança); de todas as maneiras a linguagem é pensamento e o expressar-se, na fala ou na arte, é sempre o esforço em fazer-se compreender e em comunicar um pensamento. No entanto, "há uma profunda diferença entre a expressão ‘verbal' e aquela das artes figurativas, da música, etc.”; essa diferença se acentua se entendida a partir dos elos nacionais e da tradição; os elementos sensíveis particulares mostram que, "sob a expressão de caráter 'cosmopolita' da linguagem musical, pictórica, etc.”, ou seja, nas formas de arte que assumem um caráter "[...]'internacional', existe uma substância cultural mais profunda e mais restrita, mais 'nacional-popular'[...]" (Q. 9, 1978, p. 1193), existe um elo entre os elementos universais que a música 
traduz e as características particulares da cultura que enraízam um povo em seu contexto histórico.

A arte tem uma característica universalizante e expressiva maior que a palavra, que tem um caráter mais estritamente nacional-popular; embora a oratória possa unir palavra, gesto e voz, ou seja "o elemento musical que comunica o leitmotiv do sentimento predominante" que articula razão e paixão, encontra-se também na oratória. Da perspectiva de uma história cultural, "existe entre a arte literária e as demais formas de expressão artística (figurativas, musicais, orquestrais, etc.) uma diferença que seria necessário definir e precisar de modo teoricamente justificado e compreensível”. Esse reconhecimento é fundamental para uma política cultural para as massas populares (Q. 9, p. 1194).

Essa especificidade da estética e das artes em geral não pode ser reduzida apenas a uma crítica política, embora a arte possa contribuir para a formação de tendências culturais que podem coincidir ou reforçar determinadas correntes políticas; por isso Gramsci prefere abordar esse problema no campo da história da cultura, concentrando-se na crítica literária.

A questão de fundo é que todo momento histórico-social é rico em contradições e cabe entender, do ponto de vista cultural e histórico, como interagem entre si a linguagem popular e a linguagem culta na atividade dos intelectuais, a fim de explicitar as várias formas de dominação. Cabe considerar que Gramsci trabalhava com o material que lhe chegava às mãos e em algumas ocasiões salientou que esses limites não lhe permitiam avançar pelos caminhos planejados.

Tomamos como ponto de partida as breves observações de Gramsci sobre os cantos populares, na formulação de Ermolao Rubieri, para dizer que existem três tipos de produção literária popular: 1) a composta "pelo povo e para o povo"; 2) a composta "para o povo, mas não pelo povo"; 3) a escrita "nem pelo povo nem para o povo", mas por este adotada, porque adequada à sua maneira de sentir e de pensar (Q. 5, p. 679).

Essa terceira categoria pode ser explicitada a partir do modo como Gramsci entende a formação de uma concepção de mundo e sua expressão na linguagem, como aparece no Caderno 11: “é preferível 'pensar' sem ter disso consciência crítica, de modo desagregado e ocasional, isto é, 'participar' de uma concepção de mundo 'imposta' mecanicamente pelo ambiente externo”, como o grupo social no qual estamos inseridos, a religião, as leis, a sabedoria das bruxas ou os intelectuais que dizem deter a posse do conhecimento, ou 
"é preferível elaborar a própria concepção de mundo consciente e criticamente" e, a partir daí, "escolher a própria esfera de atividade, participar ativamente na produção da história do mundo" sem aceitar passivamente que marquem, do exterior, a sua própria personalidade? (Q. 11, p. 13751376). Como se pode fazer a passagem da consciência espontânea para a consciência crítica? "Por que e como se difundem, tornando-se populares, as novas concepções de mundo?” Nesse processo interagem muitas variantes, "elementos que variam conforme o grupo social e o nível cultural" deste mesmo grupo. As massas populares mudam lentamente e nunca de forma "pura", ou seja, fazem combinações variadas e muitas vezes contraditórias. A forma racional, lógica e coerente, tem sua importância, mas não define o processo de mudança, que ocorre principalmente por razões políticas e sociais. Disso se conclui que "nas massas enquanto tais a filosofia não pode ser vivida senão como uma fé” (Q. 11, p. 1389-90).

Mesmo na solidão do cárcere, com material teórico restrito, Gramsci tenta criar uma imagem das condições empíricas que caracterizam a vida do trabalhador:

Imagine-se a posição intelectual de um homem do povo: ele se formou a partir das opiniões, das convicções, dos critérios de discriminação e das normas de conduta. Qualquer um que sustente um ponto de vista contrário ao seu, enquanto é intelectualmente superior e sabe argumentar as suas razões melhor que ele, consegue derrotá-lo logicamente; deveria ele, por isso, mudar as suas convicções? Porque não sabe fazer prevalecer sua opinião numa discussão? Se fosse assim poderia acontecer que devesse mudar de opinião uma vez ao dia, ou seja, todas as vezes que encontrasse um adversário ideológico intelectualmente superior. Em que elementos se funda, então, a sua filosofia? E especialmente a sua filosofia na forma que tem para ele maior importância, como norma de conduta? O elemento mais importante é, sem dúvida, de caráter não racional, de fé. Mas de fé em quem e em que coisa? Especialmente no grupo social ao qual pertence, enquanto este pensa difusamente como ele (Q. 11, p. 1390-1391).

Esse pensamento difuso, que agrega os indivíduos num grupo, não muda a partir da lógica ou da demonstração racional, mas sim por meio da ação política que une forças em torno de um objetivo comum. O homem de povo, mesmo que não consiga refutar os argumentos do adversário, acredita que "em tantos não se pode errar"; que "ele próprio, é verdade, não é capaz de sustentar e desenvolver as próprias razões, como o adversário sustenta e desenvolve as suas", mas em seu grupo existe quem poderia fazer uma argumentação convincente esclarecendo as razões de sua fé. As condições básicas de persuasão estão contidas nessa necessidade das pessoas simples 
de ancorarem em uma verdade que lhes garanta o sentido de viver e de lutar. As religiões têm-se aproveitado desse modo de viver uma concepção de mundo e repetem seus argumentos a exaustão, a fim de manter seus fiéis. Modificar esse cenário ideológico implica muito esforço e persistência para substituir o senso comum e as velhas concepções de mundo em geral. $\mathrm{O}$ método aconselhado por Gramsci na luta política por mudanças sociais é "não se cansar de repetir os próprios argumentos e criar os meios de elevar intelectualmente as camadas populares" criando "intelectuais de novo tipo, que surjam diretamente da massa e a ela permaneçam vinculados tornandose seu sustentáculo" (Q. 11, p. 1392).

Nesse contexto de luta hegemônica e de formação de novos intelectuais se insere a preocupação de Gramsci com a literatura popular e suas condições na história italiana dos séculos XIX e XX. Cabe explicitar o que Gramsci entendia por literatura nacional-popular ${ }^{13}$, dois conceitos que recebem um novo significado na leitura crítica do movimento político e cultural pela unificação italiana. A pergunta de Gramsci: o movimento "nacional que conduz à unificação do Estado italiano deve necessariamente desembocar no nacionalismo e no imperialismo nacionalista e militar?” A resposta é não, porque as tradições italianas, romanas antes e católicas depois, são cosmopolitas, embora isso não signifique que não se possa romper com as tradições. E isso é realmente viável, sendo a "expansão moderna de origem capitalista financeira”. A partir dessa argumentação, Gramsci acentua a correlação de forças entre capital e trabalho, para mostrar que, a partir dessas novas condições, "a tradição italiana continua dialeticamente no povo trabalhador e nos seus intelectuais”, de modo que o cosmopolitismo tradicional pode tornar-se internacionalismo, visto que "o povo italiano é aquele que 'nacionalmente' está mais interessado no internacionalismo" (Q. 9, p. 1190). Ou seja, o termo "nacional" vai sendo vinculado ao termo "popular" a partir do modo como se organiza a sociedade moderna, permeada pelas lutas de classes e pela forma como se organizam as relações de hegemonia que, da perspectiva do capitalismo financeiro, Gramsci vislumbra (embora não aprofunde) o seu desdobramento como imperialismo (Q. 9, p. 1192).

O nacional-popular define-se pela recusa ao cosmopolitismo e ao nacionalismo que predominaram na história italiana medieval e moderna para assumir um novo significado, como a expressão das contradições sociais a serem superadas na organização política dos trabalhadores, na

13 Abordarei brevemente esse termo, que já explicitei anteriormente, de modo que remeto ao meu livro intitulado Hegemonia e Cultura: Gramsci (SCHLESENER, 2007). 
sua forma mais moderna e avançada do internacionalismo. Desse modo, o conceito se expressa na cultura a partir de sua articulação política: Rafael, Verdi, assim como Dante, são populares porque a linguagem artística pode ser internacionalizada e nela os sentimentos confluem.

"Popular", por sua vez, é um adjetivo que aparece designando outros termos além de nacional como: cultura popular, literatura popular, teatro popular, canto popular, escritores populares, etc., todos eles sempre analisados no contexto histórico e político italiano. Assim, a literatura popular: primeiro, para que esta exista é preciso que haja uma identidade de concepção de mundo entre escritores e povo, isto é, que os intelectuais se identifiquem com os sentimentos, os objetivos e as expectativas das classes populares. A ausência de uma literatura nacional-popular na Itália evidencia o distanciamento entre os grupos intelectuais e a massa, fruto de um processo histórico sem grandes movimentos transformadores, no qual o paternalismo e o cosmopolitismo, de raízes imperial e católica, marcaram a formação das elites intelectuais, ora mantidas pelo mecenato, ora voltadas para atividades individuais ou cosmopolitas, sempre vinculados a uma tradição de casta, livresca e abstrata ${ }^{14}$.

Essa separação reflete-se no fato que o público italiano se interessa muito mais pela literatura estrangeira, que responde melhor a seus sentimentos e modo de vida. E esse fato revela características das relações de poder: "todo povo tem sua literatura, mas ela pode ser assimilada de um outro povo" e, do ponto de vista político, isso demonstra que esse povo se subordina a uma hegemonia intelectual e moral externa. Esse paradoxo se traduz em que "muitas tendências monopolistas, de caráter nacionalista e repressivo", que pretendem construir grandes hegemonias, "não se dão conta de serem objeto de hegemonia estrangeira, assim como, enquanto se fazem planos imperialistas, na realidade se é objeto de outros imperialismos, etc." (Q. 25, p. 2253). Essa colocação, embora breve, permite esclarecer como as relações de poder e de hegemonia se constroem a partir das mais variadas interrelações e como os intelectuais, com sua atitude livresca e abstrata, desconhecem o alcance e a profundidade política de suas funções.

Essa perspectiva abre novas questões para as classes subalternas, visto que a subalternidade se insere na dimensão das relações capitalistas

14 Estas análises da realidade intelectual italiana podem nos ajudar a compreender o distanciamento entre a literatura brasileira e as classes populares, da qual a intelectualidade permanece distante. O problema não é apenas o analfabetismo endêmico e funcional que atinge as classes trabalhadoras, que não lêem, mas o da formação de uma elite dirigente que olha e sonha com a realidade europeia ou a norte-americana. As massas que, em geral, não lêem, são cotidianamente formadas pelos canais abertos de televisão. 
internacionais. Os Cadernos 25 e 26 (assim como o 29), escritos em $1935^{15}$, nas idas e vindas entre o cárcere e a clínica, no final de suas forças, retomam anotações dos Cadernos 3 e 5 sobre a história e a cultura das classes subalternas, num esforço em mostrar um caminho de pesquisa ao historiador materialista. A questão de fundo é entender o movimento histórico e explicitar as várias formas de dominação que se consolidam no senso comum e na concepção de mundo sem articulação ou racionalidade crítica, fruto da ação, entre outros fatores, dos intelectuais.

Os grupos sociais subalternos têm seus cantos populares, mas a literatura é adotada, ou seja, assimilada daquela escrita por intelectuais que sabem expressar seus sentimentos e valores. Sem dúvida, "existe na atividade histórica desses grupos a tendência para a unificação" e ordenamento de seu saber desagregado e episódico, "mas esta tendência é continuamente destruída pela iniciativa dos grupos dominantes". Os "grupos subalternos sofrem sempre a inciativa dos grupos dominantes mesmo quando se rebelam"; somente "a vitória 'permanente' quebraria, e não imediatamente, os elos de subordinação” (Q. 25, p. 2283). A cultura, o modo de pensar, o modo como se naturalizam as relações, a assimilação de um pensamento homogêneo e da história escrita da perspectiva dos dominantes são os grilhões invisíveis que subordinam mesmo inconscientemente. Enquanto não se superar a fragmentação e descontinuidade do modo de pensar dos subalternos, enquanto não se esclarecerem os elos entre política e literatura e se superar a separação entre intelectuais e povo, esse não tem condições de produzir uma nova literatura popular. Para tal, precisa romper os elos de subordinação e criar uma nova concepção de mundo, o que acontece apenas no movimento de organização política (Q. 15, p. 1777-1779).

Gramsci vai mais além, dizendo que "ainda quando parecem triunfantes, os grupos subalternos estão apenas em estado de defesa alarmada"16. Por isso, "qualquer traço de iniciativa autônoma por parte dos grupos subalternos deveria ser de valor inestimável para o historiador integral” (eu diria, materialista). E reconhece que uma tal história é sempre difícil de escrever, principalmente porque o material é difícil de encontrar e recolher (Q. 25, p. 2283-84). Portanto, o esforço de Gramsci em fazer o levantamento da literatura popular pode ser vinculado ao seu empenho em levantar

15 Os Cadernos 25 e 26, já citados acima e compostos no mesmo período em que Gramsci organiza o Caderno 29 sobre a Gramática, são importantes para compreender a questão política que perpassa a leitura gramsciana da linguagem.

16 Gramsci cita como exemplo a história da Revolução francesa, ao menos até 1830. Um escrito básico para se entender esse exemplo seja O Dezoito Brumário de Luís Bonaparte, de Marx. 
o material para uma história dos grupos subalternos, como parte de um processo de formação de uma identidade de classe a partir da elaboração de um pensamento autônomo capaz de impulsionar uma ação inovadora, de ser a base de construção de uma nova sociabilidade.

"A unidade histórica das classes dirigentes tem lugar no Estado e a história deste é essencialmente a história dos Estados e dos grupos de Estados”. Uma unidade que não é apenas jurídica e política, mas é essencialmente "o resultado das relações orgânicas" entre sociedade política e 'sociedade civil', que constituem o Estado. As classes subalternas "não são unificadas e nem podem se unificar antes de se tornarem 'Estado'[...]”: a sua história, portanto, se confunde com a história da sociedade civil e, deste modo, faz parte da história dos Estados (Q. 25, p. 2287-2288). Essas observações antecedem a lista das fases que um historiador materialista precisa seguir para escrever a história das classes subalternas, um caminho detalhado e rigoroso que pode servir a qualquer pesquisador no seu trabalho de explicitar o real em suas múltiplas determinações:

Levantar: 1) a formação de grupos sociais subalternos pelo desenvolvimento e transformações que ocorrem no mundo da produção econômica, a sua difusão quantitativa e a sua origem a partir dos grupos sociais preexistentes, dos quais conservam, por um certo tempo, a mentalidade, a ideologia e os fins; 2) a sua adesão ativa ou passivamente às formações políticas dominantes, as tentativas de influenciar os programas destas formações para impor reivindicações próprias e as consequências que tais tentativas tem na determinação dos processos de decomposição e de renovação ou de nova formação; 3 ) o nascimento de novos partidos dos grupos dominantes para manter o consenso e o controle dos grupos subalternos; 4) as próprias formações dos grupos subalternos para reivindicações de caráter restrito e parcial; 5) as novas formações que afirmam a autonomia dos grupos subalternos, porém nos velhos quadros; 6 ) as formações que afirmam a autonomia integral, etc. (Q. 25, p. 2288)

Trata-se de um verdadeiro planejamento metodológico, como um legado de orientação a quem interessar um estudo profundo da história das classes subalternas. Um texto claro e preciso, no qual acentua que o "historiador deve observar e justificar a linha de desenvolvimento em direção à completa autonomia, desde as fases mais primitivas" até as manifestações de divisão, considerando sempre a complexidade dessas formações. Precisa explicitar o conjunto de relações de força, ou seja, as repercussões e os impactos que as ações dos grupos subalternos exercem sobre os grupos dominantes e as ações destes para manter o poder, ações "muito mais eficazes porque apoiadas pelo Estado". Um historiador deve ainda evidenciar as relações 
internas dos movimentos sociais e como, "entre os grupos subalternos, um exerce ou tende a exercer uma certa hegemonia por meio do partido”, de modo que cabe estudar as relações entre tendências e partidos, tanto das classes subalternas quanto dos grupos dominantes. "Muitos critérios de pesquisa podem ser elaborados a partir da análise das forças inovadoras" que prepararam o Risorgimento italiano (Q. 25, p. 2288-2289). Pode-se dizer o mesmo da Revolução francesa ou do nascimento da burguesia a partir das relações comunais medievais.

Fazer a história das classes subalternas tem um caráter pedagógico: como enfrentar de modo crítico o senso comum, mostrando seus limites ideológicos, sem ferir o sentimento popular? Como posicionar-se ante "as crenças e ilusões populares" (justiça, igualdade, fraternidade, ou seja, "elementos ideológicos difundidos pelas tendências democráticas herdeiras da Revolução francesa") de modo criativo e positivo? Com um "sarcasmo apaixonado", desvelando os limites reais dessas crenças de modo a dar-lhes uma nova forma inovadora (Q. 26, p. 2300).

Seguem-se recomendações, como ter o cuidado de "manter o contato com as expressões subalternas" das velhas concepções e, ao mesmo tempo, "acentuar a diferença daquelas dominantes e dirigentes", esperando que os novos conceitos, adquiridos no desenvolvimento histórico, alcancem a força de novas crenças populares. A atitude de quem usa o sarcasmo e, portanto, já se apropriou de novos conceitos, deve ser uma atitude polêmica, de quem levanta as contradições e salienta o movimento histórico no qual elas se produzem e podem ser superadas. “Por sua própria natureza, o 'historicismo' não pode exprimir-se de forma apodítica e doutrinária”, mas precisa criar uma nova linguagem como meio de luta intelectual. "O 'sarcasmo' aparece como o componente literário", com "exigências teóricas e práticas que podem superficialmente aparecer como insanavelmente contraditórias”; o critério metodológico de abordagem é a "passionalidade" que se expressa na sinceridade do educador (Q. 26, p. 2301).

De tudo o que se acentuou acima, salienta-se que um gramático não pode esquecer a história da língua e essa história se constrói no contexto de lutas políticas pelo poder ou pela hegemonia. Para Gramsci, esse foi o caso da língua italiana, a partir dos estudos de Dante Alighieri, que ele aborda, ainda que indiretamente, na sua leitura do Canto X, do Inferno. Gramsci insere-se num debate sobre a poesia dantesca já em 1918, quando publica no Avanti1 o artigo Il cieco Tiresia, no qual toma como motivo narrativas populares a respeito de previsões ocorridas no final da Primeira guerra, a 
partir de notícias de jornais sobre uma menina do interior da Itália que, depois de prever o final da guerra, ficou cega. O tema de fundo desse artigo, que retorna nos Cadernos, é a contraposição da chamada alta cultura (burguesa e católica) com a cultura popular. (Q. 6, p. 833-834).

Nas narrativas antigas, a cegueira é uma característica dos videntes e dos sábios. No Caderno 4 e 5, Gramsci acentua que na "tradição literária e no folclore o dom de previsão vem sempre vinculado a uma enfermidade atual do vidente que, embora veja o futuro, não vê o presente imediato porque cego". A crença na vidência é própria da cultura popular, enquanto a narrativa culta e refinada prefere dados mais racionais ou conforme a ordem natural das coisas. Tirésias éfruto da expressão popular e a sua experiência ressignificada por Dante no Canto $\mathrm{X}$ do Inferno, na figura de Cavalcante, implica a repercussão do popular na literatura culta (Q. 4, p. 527).

A língua italiana, de origem popular, torna-se ao longo da história italiana a língua dos intelectuais e da alta cultura, enquanto as classes subalternas se encerram nos dialetos de suas regiões. Explicitar essa história apresenta-se como um dos caminhos para acentuar a dimensão política e ideológica da linguagem, na formação de uma elite intelectual que constrói o discurso hegemônico e na submissão passiva dos subalternos, que aderem ao instituído sem perceber que, com isso, perdem as principais condições de autonomia porque perdem a sua voz.

Dias (2012, p. 67-69) acentua que o debate do início do século XX, firmava-se na "centralidade da relação intelectual-política" e que o movimento revolucionário europeu, incluindo a direção do Partido Social Democrata Russo, era constituído por intelectuais que foram seus principais dirigentes. Nesse contexto, o pensamento dos subalternos se elaborava a partir da voz do outro, que vinha da classe dominante. Daí a importância das observações de Gramsci sobre a necessidade de as classes subalternas formarem os seus próprios intelectuais.

"Quando se delega também no interior do partido, a direção partidária, a capacidade de pensar os projetos, as lutas, o subalterno continua subalterno". Dessa perspectiva, a "proposta gramsciana de partido é um escândalo radical diante da prática de socialistas e comunistas que vivem o fetichismo da organização" (DIAS, 2012, p. 70). Gramsci não nega a importância da organização política, mas defende intransigentemente a participação efetiva dos trabalhadores na estrutura interna do partido (sindicatos, etc.), 
na prática de uma democracia efetiva expressa na mobilidade de direção, tornando o partido uma escola de formação de dirigentes ${ }^{17}$.

Dessa perspectiva, a linguagem assume a sua verdadeira dimensão política, na crítica ao senso comum, na elaboração de uma nova concepção de mundo como instrumento de emancipação política, porque meio de superação ideológica, de educação para uma nova ordem social e política. A importância de uma reforma intelectual e moral a partir da formação de novos intelectuais orgânicos tem como pressuposto a dimensão política da linguagem e o envolvimento dos intelectuais com as massas.

Neste contexto, a ideologia permeia as relações sociais e políticas, formando a nossa subjetividade; nas agudas palavras de Pasolini, um intelectual solitário, leitor e também crítico do marxismo, encontramos a definição de burguesia e, por extensão, a ideia de indivíduo que se solidificou no senso comum:

Por burguesia não entendo tanto uma classe social quanto uma verdadeira doença. Uma doença muito contagiosa: tanto que ela contagiou quase todos os que a combatem. [...] O burguês - digamos espirituosamente - é um vampiro, que não fica em paz enquanto não morde sua vítima no pescoço, pelo puro, simples e natural prazer de vê-la se tornar pálida, triste, feia, desvitalizada, disforme, corrompida, inquieta, cheia de sentimentos de culpa, calculista, agressiva, terrorista, tal como ele mesmo (PASOLINI, 1982, p. 38).

O que Pasolini denuncia é a assimilação de pensamento e de comportamento próprios da burguesia, que os meios de comunicação de massa se encarregam de formar de um modo unívoco, ampliando a miséria da alienação a fim de fortalecer os laços inconscientes de submissão. Os meios de comunicação de massa nos tornam indiferenciados e indiferentes aos problemas e inclusive à existência de classes sociais antagônicas, menos ainda às lutas de classes.

Nesse contexto de leitura a crítica da linguagem e de seus efeitos políticos se apresenta como um dos momentos de elaboração do conceito de hegemonia, ou seja, na constituição e manutenção de uma elite de intelectuais capaz de elaborar um consenso ou de alimentar o senso comum com fragmentos de culturas mesclados com informações pretensamente neutras a fim de incentivar a aceitação do dado, a naturalização da história, a

17 Gramsci sempre se posicionou contra um partido burocratizado, que concentra a direção nas mãos de um grupo, fato evidenciado nas experiências do conselho de Fábrica e no jornal L'Ordine Nuovo, mais tarde explicitado na correspondência trocada com Togliatti em 1926 e retomada nos fragmentos dos Cadernos do Cárcere que abordam a questão do partido e do Estado. 
passividade ante o estabelecido, contribuindo para a estabilidade da prática social. Desenha-se assim a ideia de que existe uma verdade igual para todos, visto que, para ser "verdade", não pode se sustentar nem se referir à divisão de classes. Ela não existe, porque vive-se numa "democracia" onde todos são "iguais" perante a lei e usufruem dos mesmos direitos como indivíduos isolados; para Eagleton (1997, p. 196-197) estabelece-se aqui uma das fortes fontes de hegemonia consolidada no sistema parlamentar, ou seja, "supostamente, as pessoas acreditam governar a si mesmas, crença esta que não se esperaria ver alimentada por nenhum escravo da Antiguidade ou servo medieval". Gramsci ampliou, por meio do conceito de hegemonia, a noção de ideologia, que tomou "corpo material e agudeza política" ao ser transposta para a prática social cotidiana podendo abranger "dimensões inconscientes e não articuladas da experiência social”.

Eagleton (1997, p. 107) define a hegemonia como uma gama de "estratégias práticas pelas quais um poder dominante obtém o consentimento ao seu domínio daqueles que subjuga". Acrescentamos que esse consentimento pode ser inconsciente, na medida em que as relações sociais são naturalizadas e a divisão de classes diluída por meio das ideias de igualdade e liberdade individual, assimiladas no curso do processo educativo; para explicitar as relações de hegemonia torna-se necessário mostrar que a linguagem radica-se na estrutura da sociedade, tem raízes histórico-sociais e, portanto, é ideológica e funciona como instrumento de poder e de dominação.

A divulgação de uma ideologia unificadora, ao lado do controle ideológico pelas diversas vias que compõe a divulgação do "saber" na forma de informação, atua para consolidar a alienação na qual estamos imersos, cuja superação implica um movimento efetivo de organização política, que caminhe pari passu com a superação da fragmentação que caracteriza o modo de pensar dos subalternos. Muito além do que propõe os pragmáticos, a linguagem tem uma função central nesse processo e falar de linguagem implica remeter-nos à questão da educação.

Concentramo-nos na questão da linguagem por entendermos fundamental explicitar a sua dimensão ideológica no contexto dos escritos de Marx e Gramsci, a fim de salientar que a dialética marxista se constrói a partir da empiria e do modo de produção (trabalho) e não da linguagem, embora se possa fazer recortes do texto de Marx para dizer o contrário. Pensamos ter esclarecido implicitamente no corpo de nosso texto a amplitude do desafio educativo e formativo a enfrentar no contexto da sociedade capitalista contemporânea, não apenas como um desafio dos pedagogos, 
mas de todos os intelectuais que se dizem leitores de Marx. Um desafio que passa pela reorganização dos movimentos populares e que se apresenta na nova dimensão da luta de classes enquanto uma luta econômica, política e cultural. A exposição até aqui desenvolvida nos possibilita, agora, abordar a questão da educação.

A importância da educação formal se apresenta no fato que a luta de classes assume uma dimensão ideológica sempre mais acentuada e a fragilidade das classes subalternas se sedimenta precisamente no fato de não terem condições de sistematizar seu pensamento contra o pensamento dominante e de somente poderem fazê-lo a partir da consolidação de sua organização política. $\mathrm{O}$ fato de haverem fracassado em suas lutas no curso da história não significa que suas reivindicações não eram válidas; a derrota, porém, traz consigo a perda das condições de possibilidade de articular num pensamento coerente as ações realizadas a fim de se contrapor a uma leitura histórica hegemônica.

A dialética supera a lógica formal, mas não abole a sua necessidade e a escola é a única instituição burguesa que possibilita o acesso a esses códigos de raciocínio e de domínio do conhecimento, básicos para ir adiante na formulação de um pensamento crítico. 


\section{CAPÍTULO IV}

\section{As nOVAS CONDIÇões DE SUBALTERNIDADE}

O pensamento dos subalternos não pode deixar de ser subversivo se quiserem transformar a sua subjetividade em objetividade

universal (DIAS, 2012, p. 69)

O tema deste capítulo implica retomar a questão da hegemonia e da educação no contexto das relações econômicas, sociais, políticas e culturais que caracterizam a sociedade capitalista. Gramsci, a propósito da realidade italiana, amplia o conceito de classe social derivado dos escritos de Marx para a oposição dominante - dominados, dirigentes - dirigidos e, no caso das classes trabalhadoras, acrescenta o adjetivo "subalternos" que, em nosso entender, abre novas possibilidades de pensar o capitalismo na sua fase neoliberal e financeira.

As observações sobre os grupos sociais subalternos encontram-se no Caderno 25, de 1934, com o título À margem da história, além de vários fragmentos dispersos ao longo de sua obra e que tratam do tema História das classes subalternas, nos quais Gramsci inicia um trabalho de análise das lutas populares no curo da história italiana. O Caderno 25 traz, em segunda redação, fragmentos do Caderno 3, escrito em 1930, ou seja, do início de suas pesquisas; com apenas 15 páginas redigidas, encontramos praticamente um plano de trabalho com critérios metodológicos, bibliografia a ser consultada sobre os movimentos populares, que retoma inclusive os levantes e a resistência dos escravos romanos, o desenvolvimento histórico dos grupos subalternos na Idade Medieval, alertando para os perigos em fazer analogias históricas como critério de interpretação e de comparação entre épocas distintas (Q. 25, p. 2286-2287). Nesse contexto, amplia-se o significado de subalterno a todas as classes oprimidas da história da civilização moderna, a todos os marginalizados do processo histórico, tanto os que resistem à dominação demonstrando alguma consciência de classe, quanto os que se encontram completamente à margem, sem uma consciência clara de sua condição de classe, ou mesmo da dominação à qual estão submetidos.

Gramsci demonstra um profundo interesse pelos movimentos populares, desde a fase das comunas medievais, o modo como os romances 
de época refletem de forma "inconsciente as aspirações mais elementares e profundas dos grupos sociais subalternos” (Q. 25, p. 2290). Salienta o modo como os intelectuais se expressam na literatura sobre a vida popular e procura identificar todos os sinais de resistência, mesmo na forma desagregada e mistificada que esses movimentos assumem em função da própria subalternidade. Salienta as características diversificadas que assume a utopia nos movimentos populares de países protestantes e nos que centralizam a Contrarreforma. Enfim, acentua as formas de escrever uma nova história do ponto de vista dos movimentos populares de resistência como condição de enfrentamento da luta para construir uma nova hegemonia.

Neste embate, a questão meridional está implícita e parece constantemente retomada na análise do modelo capitalista, passando pelo problema histórico do transformismo e suas raízes no Risorgimento, pelo qual a formação de uma ampla classe dirigente no quadro dos moderados "com a absorção gradual e contínua, obtida com métodos diversos na sua eficácia, dos elementos ativos saídos dos grupos aliados e também dos adversários”. Esse processo realizado de forma continuada torna a direção política "um aspecto da função de domínio" levando à "decapitação dos grupos inimigos e ao seu aniquilamento por um período muitas vezes longo" (Q. 19, p. 2011). Esse tipo de ação política desmobilizou os movimentos sociais populares do Sul da Itália, subordinando-os à hegemonia do Norte e dificultando o processo de organização dos trabalhadores.

Essas questões começam a aparecer de modo fragmentário no Caderno 3, com o título História das classes subalternas, fragmentos que se completam com outros, denominados Passado e Presente, fazendo uma nova leitura de fatos históricos que envolveram as classes subalternas, que acentua a visão das elites e suas contradições a respeito da história italiana. Um exemplo é o pequeno parágrafo 45, que aborda a questão aprofundada posteriormente no tema transformismo: trata da debilidade teórica de alguns dirigentes de esquerda, que se traduzem em "uma das causas das catástrofes”. E acrescenta: "quando falta uma atividade cultural do partido", a classes populares "produzem a cultura como podem" (Q 3, p. 323).

No fragmento seguinte, nomeado Passado e Presente, esclarece-se o significado do conceito "subversivo" e seu caráter negativo na concepção de mundo dos camponeses: estes "sentem que tem inimigos e os identificam somente empiricamente nos assim chamados senhores". O conceito de senhor, por sua vez, traz implícita a antiga aversão dos camponeses pela cidade, pela burocracia, pelos 'funcionários' de Estado, que se apresentam 
como superiores, embora da perspectiva econômica sejam mais pobres que alguns camponeses. “Este ódio 'genérico’ é ainda de tipo 'semifeudal', não moderno, não podendo ser tomado como documento de consciência de classe"; trata-se apenas de uma atitude negativa e polêmica elementar. E Gramsci acentua algo que reaparece na sua análise do Risorgimento: o camponês "não apenas não tem consciência exata da própria personalidade histórica”, como também "não tem consciência da personalidade histórica e dos limites precisos do próprio adversário” (Q. 3, p. 323-324). Dessa perspectiva, toda a análise gramsciana das relações de forças que caracterizaram o Risorgimento e do desdobramento conservador da política que penalizou o Sul pode ser tomada como parte da História das classes subalternas.

Essa realidade caracteriza a condição social e política da subalternidade, que explicitamos a partir da abordagem da categoria classe social e do modo como Gramsci a modifica para esclarecer as novas dimensões da luta de classes. Se, a partir de Marx, as classes sociais se definem pela participação no processo produtivo, a introdução da noção de subalterno não nega que a delimitação do significado se encontra no processo de produção material, mas permite relacionar o econômico, o político e o ideológico, para explicitar, na unidade dialética dessas instâncias, as relações de dominação.

\section{Explicitações filológicas quanto ao conceito subalternidade}

Até que os leões tenham seus próprios historiadores, as histórias de caçadas continuarão glorificando o caçador (GALEANO, 1997,

p. 115)

A categoria geral de classe social, recorrente nos escritos de Marx e identificada no movimento concreto de luta de classes como burguesia, proletariado, campesinato, pequena-burguesia, etc., foi reelaborada por Gramsci na oposição: classes dominantes e classes ou grupos subalternos. Essa mudança vincula-se, conforme Del Roio (2007, p. 64), ao modo como Gramsci aborda a questão meridional italiana, perspectiva da qual Gramsci traduz o "pensamento de Lenin para as circunstâncias concretas da Itália".

Para Del Roio (2007, p. 66), o movimento operário italiano deveria "unificar a classe operária dentro de uma perspectiva política e cultural" que reconhecesse a necessidade da "aliança com o campesinato, num contexto internacional de atualidade da revolução socialista”. A especificidade da realidade italiana se encontra, portanto, na base desses desdobramentos na elaboração teórica de Gramsci. 
Neste contexto, as classes se caracterizam a partir do modo de produção como dominantes e dominados, dirigentes e dirigidos e todas as classes podem possuir grupos ou frações de classe: a burguesia constitui-se de comerciantes, industriais, banqueiros e cada um desses grupos se subdivide em outros; o operariado e o campesinato, também se constituem em grupos ainda mais fragmentados por suas dificuldades de organização política e de formação uma identidade de classe.

A partir dessa realidade entende-se que, para Gramsci, os grupos subalternos são grupos que ainda não se organizaram concretamente como classe, em vista de suas condições de dominados no contexto de uma hegemonia que lhes é exterior; mesmo como classes subalternas, ainda não possuem uma história ou um pensamento sistematizado e suas tentativas de unificar a sua atividade histórica será sempre provisória enquanto não se constituírem em Estado. A força hegemônica das classes dominantes se consolida porque a sua unidade histórica se concretiza a partir da estrutura do Estado, por meio da qual se empenha em romper toda iniciativa dos grupos subalternos no sentido de sua unificação teórica (Q. 25, p. 2287).

Os grupos subalternos, na medida em que não possuem ainda uma unidade política concreta e orgânica que lhes permita assumir o poder, têm dificuldades em construir uma unidade ideológica que lhes garanta uma solidez organizativa. Sendo contraditórias as relações sociais, também "é contraditória a consciência histórica dos homens". A ausência de uma unidade política se expressa como "ausência de iniciativa histórica", de modo que a "desagregação é mais grave" e deve ser "mais forte a luta para libertar-se dos princípios impostos e não propostos autonomamente, para se alcançar uma consciência histórica autônoma” (Q. 8, p. 1033).

A consciência histórica se produz no curso da luta de classes, na medida em que esses grupos formem seus próprios intelectuais que consigam unificar teoria e prática, ou seja, elaborar coerentemente os princípios esclarecedores dos problemas e das contradições vividas. Por isso, Gramsci acentua que as relações de forças que caracterizam a luta de classes inicialmente têm um caráter eminentemente econômico e que uma nova cultura em gestação florescerá plenamente somente após a criação do novo Estado. Essa tarefa é extremamente difícil e supõe criar um grupo de novos intelectuais, criação que implica "um longo processo, com ações e reações, adesões e dissoluções e novas formações numerosas e complexas”. A filosofia da praxis se apresenta como "a concepção de um grupo social subalterno sem iniciativa histórica, que se amplia continuamente, mas desorganicamente e sem poder 
ultrapassar um certo grau qualitativo", sempre distante da tomada do poder do Estado e do exercício real da hegemonia (Q. 16, p. 1860-1861). Porque age dentro dos limites impostos pelas classes dominantes sem questionar esses limites, sucumbe, por maiores que sejam seus esforços.

Conforme Dias (2012, p. 72), "subalterno é aquele que não pode falar, que não tem voz”. E, em geral, também não tem oportunidade de produzir seu pensamento e manifesta-se, na maioria das vezes, quando lhe "dão a voz", ou seja, ainda no contexto da subordinação e do domínio dos dirigentes. Com a assimilação do modo de pensar dominante, as classes subalternas elaboram sua leitura da realidade dentro dos limites das narrativas dominantes, o que dificulta ou mesmo impossibilita perceber a própria subordinação. Dessa perspectiva, conceitos como igualdade, liberdade, cidadania, são assimilados de forma abstrata, porque entendidos como universais enquanto, na realidade, representam o significado parcial de classe.

Gramsci identifica essa dificuldade quando aborda a questão da ideologia e da linguagem ou quando acentua que os grupos subalternos vivem uma contradição permanente entre seu agir e seu pensar: seu agir é permeado de um materialismo com várias nuances, enquanto seu modo de pensar é idealista, permeado por crenças variadas e pela religião. Essa questão aparece na afirmação de que “todos os homens são filósofos”, ainda que inconscientemente, na medida em que vivem conforme uma filosofia espontânea que está contida "na linguagem, composta de noções e conceitos determinados e não, simplesmente, de palavras gramaticalmente vazias de conteúdo"; no senso comum e na religião popular. Ou seja, esse pensamento é desagregado e contraditório, na medida em que o pensar se elabora a partir de elementos “[...]'impostos' mecanicamente pelo ambiente exterior”, caracterizado pela tendência teórica dos grupos dominantes (Q. 11, p. 1375-1376).

O homem ativo de massa atua praticamente, mas não tem uma consciência teórica clara de sua ação que, entretanto, é um conhecer o mundo enquanto o transforma. A sua consciência teórica pode estar historicamente em contradição com a sua ação. Pode-se quase dizer que ele tem duas consciências teóricas (ou uma consciência contraditória): uma implícita na sua ação e que realmente o une a todos os seus colaboradores na transformação prática da realidade e uma superficialmente explícita ou verbal que herdou do passado e acolheu sem crítica (Q. 11, p. 1385).

Essa característica da subalternidade, que tem como base a dominação econômica que se organiza na estrutura política e ideológica da sociedade, 
não permite aos grupos subalternos identificar a grande contradição entre o seu modo de pensar e a sua ação cotidiana. Ao conseguir superar essa dificuldade, o subalterno pode compreender que sua ação se encontra permeada por um autêntico materialismo que Gramsci assim define como o significado geral para o senso comum: "chama-se de materialismo a tudo aquilo que tende a encontrar nesta terra e não no paraíso, a finalidade da vida”, ou seja, "toda atividade econômica que saísse dos limites da produção medieval era 'materialismo'[...]", porque aparecia como um "fim em si”: a "economia pela economia, a atividade pela atividade" (Q. 11, 1407).

$\mathrm{O}$ materialismo que permeia o senso comum tem origens religiosas, conforme Gramsci: o público popular acredita que o mundo externo é objetivo em si, crença que tem origem na religião, que ensina que "o mundo, a natureza, o universo, foi criado por Deus antes da criação do homem”; este "encontrou o mundo já belo e pronto, catalogado e definido uma vez para sempre" (Q. 11, p. 1412). Esse materialismo metafisico precisa ser superado pela dialética, trabalho árduo e difícil até mesmo para alguns teóricos marxistas. Para as pessoas comuns, esse fato expressa a distância entre ciência e vida, entre intelectuais e povo, entre a chamada "alta cultura" e as classes populares.

Da perspectiva histórica, o materialismo originou-se na Grécia Antiga, com Tales de Mileto no século VI a.C., com raízes "na atividade produtiva diária da humanidade", levando mais de dois mil e quinhentos anos para "adquirir sua atual clareza e amplitude", a partir da criação das "condições históricas necessárias para dar o salto do realismo ingênuo da vida primitiva" até a sua formulação teórica no materialismo histórico (NOVACK, 2015, p. 17-18).

As reflexões dos primeiros filósofos, denominados naturalistas, nasceram da observação da atividade humana e dos fenômenos da natureza e seus escritos articulavam ciência e filosofia. Conforme Novack (2015, p. 88), o "impulso dado ao pensamento abstrato pela difusão da escrita, depois da invenção do alfabeto", foi proporcional ao que antes resultava da análise da experiência, do "intercambio de mercadorias, do cálculo de preços" ou da medida da terra. A escrita permitiu objetivar a fala e aprofundar "elementos estruturais da língua”, base para a transformação desses primeiros teóricos em "retóricos, gramáticos e lógicos".

Uma história da qual sabemos pouco, porque a narrativa hegemônica foi marcada por uma posição idealista, que leu e interpretou a teoria 
materialista de um modo parcial e distorcido. A perspectiva racionalista que dominou a narrativa filosófica a partir de Platão teve como ponto fundamental a dissociação do processo reflexivo da análise das circunstancias históricas, do movimento da natureza e da vida, que produz os antagonismos sociais implícitos nas reflexões dos materialistas. Porém, por surgir "da atividade prática da sociedade e impregnar todos os aspectos da vida humana", o materialismo tinha uma necessidade poderosa de se expressar e "poderia até chegar a se banido da filosofia oficial sem, com isso, deixar de se afirmar por todos os lados" (NOVACK, 2015, p. 24).

Estas raízes históricas são importantes na medida em que os fundadores da filosofia da praxis nelas buscaram inspiração. Veja-se a Tese de Doutorado em Filosofia de 1841, de Marx, com o título: A diferença entre a filosofia da natureza de Demócrito e a de Epicuro. Essa base inicial materialista desenvolve-se com a leitura de Feuerbach, para seguir adiante na crítica ao materialismo filosófico, metafisico e concretizar-se no que Gramsci denomina materialismo histórico ou filosofia da praxis.

Já na $1^{\text {a }}$ das Teses contra Feuerbach (MARX, 1974, p. 57), Marx se posiciona tanto ante o materialismo filosófico quanto ante o idealismo a partir da explicitação da relação dialética entre objetivo e subjetivo no conceito de praxis como "atividade humana sensível”. Como acentua Labica (1990, p. 49 e 51), Marx toma distância de Feuerbach e do materialismo filosófico definindo a atividade humana sensível como "atividade revolucionária, praticamente crítica”, entendendo-se que a "crítica só tem sentido prático e só possui eficácia ao se traduzir em atividade prática”, ou seja, essa prática é necessariamente revolucionária.

Trata-se de uma abordagem que, na medida em que é praticamente crítica, altera o significado de conceitos como "sensível”, "real” e também "prático" e "humano". Supera-se o imediatamente dado para entender o conjunto das relações sociais em suas contradições e possibilidades latentes ${ }^{1}$. Labica (1990, p. 74-75), explicita a diferença estabelecida por Marx entre teoria e pensamento: enquanto a teoria separa, analisa, tenta identificar o objeto a partir de oposições, o pensamento articula, relaciona dialeticamente, "não possui outra fonte que não seja a prática", enquanto "atividade real” (mundana, social e histórica), "sensível, humana, objetiva-subjetiva”.

Gramsci desenvolve essa posição na crítica aos dois revisionismos de Marx, principalmente as abordagens de Croce e de Bukharin. No curso de

1 A questão filológica se articula com a política, a história e a filosofia, fato que aparece acentuadamente nos escritos de Gramsci, nas perguntas: o que é o homem? O que é a natureza humana? 
ambas as críticas, a acentuação da historicidade do pensamento e da especificidade da filosofia da praxis como superação tanto do idealismo quanto do mecanicismo, pela identificação entre filosofia, política e historia como ponto de superação de toda a filosofia anterior.

O materialismo, em geral, tem um vínculo mais direto com a prática, o que o faz mais fácil de reconhecer na cultura popular. No âmbito do senso comum "chama-se materialismo tudo o que tende a encontrar nesta terra e não no paraíso o fim da vida”. No período medieval, por exemplo, toda a atividade econômica, que tinha um fim em si mesma, se denominava materialista. Com o desenvolvimento do capitalismo, essa noção se consolidou na prática econômica da burguesia (Q. 11, p. 1409).

Gramsci acentua que, da perspectiva política, o materialismo é conhecido do povo e faz parte do senso comum, na medida em que as massas convivem com muitas crenças, preconceitos e superstições populares, o que "também se percebe no catolicismo popular e especialmente na ortodoxia bizantina"; na verdade, parece que no senso comum convivem duas religiões, uma popular e materialista e outra oficial, dos intelectuais, que procuram não se separar das massas. Muitas "tentativas consideradas heréticas foram manifestações de forças populares para reformar a Igreja e aproximá-la do povo" (Q. 16, p. 1861-1862).

Da perspectiva dos grupos subalternos, enquanto eles não tiverem construído novas relações econômicas e sociais, sua "atividade não pode ser prevalentemente econômica ou, ao menos, exprimir-se em termos econômicos e de estrutura" (Q. 11, p. 1409). Gramsci não avança aqui sobre os motivos, mas eles se explicitam nas análises sobre as mudanças das lutas de classes a partir do fracasso da Comuna de Paris, na questão do transformismo e da revolução passiva e, principalmente, na explicitação do conceito de hegemonia e nas novas dimensões da ideologia como prática de poder. Os grupos subalternos sofrem de forma mais incisiva a iniciativa e a direção dos grupos dominantes, podendo organizar-se solidamente apenas quando se tornarem Estado (Q. 25, p. 2283-2284).

Romper este círculo vicioso implica formar seus próprios intelectuais e aproveitar todas as oportunidades de resistência e de ação inovadora, que possibilitam formular uma nova concepção de mundo a partir da identificação das contradições. Dessa perspectiva, a questão da educação no seu sentido amplo perpassa a luta de classes e lhe dá uma nova dimensão no contexto da hegemonia. 


\section{A filosofia da praxis como a teoria dos grupos subalternos:}

Quantas vezes não se falou de 'crise' da filosofia da praxis? E que significa esta crise permanente? Não significa talvez a própria vida que se desenvolve de negação em negação? (Q. 1O, p. 1292).

O tema "filosofia da praxis" (inicialmente denominada por Gramsci de materialismo histórico) permeia de ponta a ponta os Cadernos do Cárcere, no confronto, na crítica e na desconstrução dos argumentos de intelectuais representantes das classes dominantes e na análise da realidade política italiana.

Na análise dos movimentos populares ocorridos na história da Itália com o objetivo de salientar a importância de uma História das classes subalternas, Gramsci acentua que o elemento de espontaneidade é característico destes movimentos e "dos elementos mais marginais e periféricos destas classes, que não alcançaram a consciência de classe" e, por isso, nem desconfiam que "a sua história possa ter alguma importância e que tenha algum valor deixar traços documentais”. Em todo movimento espontâneo de resistência existem elementos de direção consciente, mas são frágeis e não ultrapassam os níveis do senso comum (Q. 3, p. 328).

Essas primeiras reflexões sobre a organização política das classes subalternas acentuam a necessidade de articular espontaneidade e direção consciente, articulação que Gramsci denomina disciplina: a) no sentido de educar as combinações espontâneas existentes no âmbito das relações sociais e dos movimentos de resistência; b) na formação de dirigentes nascidos de seus movimentos para organizá-las e depurá-las dos elementos estranhos e conservadores, para torná-las homogêneas, vivas e historicamente eficientes; c) para uma "ação política real das classes subalternas, enquanto política de massa e não simplesmente aventura de grupos" que dizem representar as massas (Q. 3, p. 330).

"Descuidar desta preparação, desprezar os movimentos espontâneos e renunciar a elevá-los a um nível superior inserindo-os na política" pode tornar-se um erro grave, com sérias consequências. Trata-se de dar uma direção consciente aos movimentos que nascem espontaneamente, a fim de "torná-los um fator político positivo" (Q. 3, p. 331).

Acontece quase sempre que um movimento 'espontâneo' das classes subalternas seja acompanhado por um movimento reacionário da direita da classe dominante, por motivos concomitantes: por exemplo, uma crise econômica determina, por um lado, descontentamento nas classes 
subalternas e movimentos espontâneos de massa e, por outro, determina conspirações dos grupos reacionários que aproveitam do enfraquecimento objetivo do governo para tentar golpes de Estado. Entre as causas eficientes destes golpes de Estado deve-se colocar a renúncia dos grupos responsáveis a dar uma direção consciente aos movimentos espontâneos (Q. 3, p. 331).

Direção consciente para fortalecer o movimento e elevar as massas a um nível superior de compreensão da luta de classes. A filosofia da praxis procura responder a todas essas questões, por ser a teoria das contradições e, como tal, propor-se a viabilizar a crítica política e a formação de uma nova concepção de mundo. Para Gramsci, Marx concretizou na filosofia da praxis uma concepção de mundo que expressa a passagem da "ciência para a ação" (Q. 7, p. 881).

Para entender o movimento orgânico da realidade em suas complexas relações e interações o primeiro problema é retomar "o significado da dialética" que precisa ser "concebida em toda a sua fundamentalidade", ou seja, entendendo-se a filosofia da praxis como uma "filosofia integral ${ }^{2}$ e original que inicia uma nova fase na história e no desenvolvimento mundial do pensamento", porque "supera (e, superando, integra em si os seus elementos vitais) tanto o idealismo quanto o materialismo tradicionais". O segundo problema de erro de interpretação é psicológico: "sente-se que a dialética é coisa muito árdua e difícil”, porque o "pensar dialeticamente vai contra o vulgar senso comum que é dogmático, ávido de certezas” concludentes, nos limites da lógica formal, que garante o seu cotidiano fragmentado (Q. 11, p. 1425) ${ }^{3}$.

Em geral "confunde-se estrutura com 'estrutura material' e 'instrumento técnico' com qualquer instrumento material, etc.”; por esse caminho, "chega-se a sustentar que uma determinada arte surgiu porque foram desenvolvidos alguns instrumentos específicos por meio dos quais as expressões artísticas" puderam aparecer. "Não se pode negar uma certa relação, mas não direta e imediata”. No movimento relacional que constitui o social torna-se, muitas vezes, difícil de separar estrutura e superestrutura, ou seja, existem fatos que são estrutura e superestrutura ao mesmo tempo.

2 Tendo-se em vista a identificação entre filosofia e história, o conceito de filosofia integral relaciona-se com o de história integral. Um belíssimo artigo sobre esse tema: (FROSINI, 2013).

3 Gramsci completa essa reflexão com um exemplo: "Para entender melhor pode-se pensar o que aconteceria se nas escolas primárias e secundárias as ciências naturais e físicas fossem ensinadas com base no relativismo de Einstein e acompanhando as noções tradicionais de 'lei da natureza' com as de lei estatística ou de grandes números. Os meninos não entenderiam nada de nada e o confronto entre o ensino escolar e a vida familiar e popular seria tal que a escola se tornaria objeto de risos e de ceticismo caricatural” (Q. 11, 24, p. 1425-1426). 
O surgimento da indústria tipográfica, por exemplo, mudou a estrutura do modo de produção, a luta de classes e o modo de pensar e de ser, inseparáveis da formação ideológica enquanto cultura, ciência, política, etc. "Uma classe se forma sobre a base de sua função no mundo produtivo"; no movimento de organização social e na "luta pelo poder e pela conservação do poder", essa classe cria ideologias que a sustentam e que repercutem no movimento estrutural alterando-o, num movimento complexo de interrelações (Q. 4, p. 433-434). A única teoria capaz de explicitar este movimento dialético é a filosofia da praxis, enquanto articula dialeticamente teoria e prática e, com isso, pode identificar as contradições do movimento social e desmistificá-las.

Essa questão é complexa e Gramsci recomenda muita cautela no seu tratamento, pois pode-se correr três riscos que inviabilizam a leitura da relação estrutura-superestrutura: 1) a "dificuldade de identificar estaticamente (como imagem fotográfica instantânea), a cada momento, a estrutura”; 2) a articulação entre o movimento estrutural e os atos políticos dos dirigentes das classes dominantes; 3) a dificuldade de identificar as necessidades internas de caráter organizativo e seus desdobramentos no movimento da estrutura, assim como nos âmbitos político e ideológico (Q. 7, p. 872-873)4.

A segunda dificuldade acima colocada por Gramsci decorre da primeira: conforme já acentuamos, uma "fase estrutural pode ser concretamente estudada e analisada somente depois de haver superado todo o seu processo de desenvolvimento" e que, no processo em andamento, a estrutura pode ser estudada apenas por hipótese. Com esse pressuposto, as ações políticas podem decorrer com base em "erro de cálculo da parte dos dirigentes das classes dominantes, erro que o desenvolvimento histórico, por meio de 'crises' parlamentares”, pode corrigir e superar. Quando não se avalia corretamente o conjunto de relações em presença e se reduz tudo ao econômico torna-se difícil tomar as medidas políticas corretas. (Q. 7, p. 872).

A terceira dificuldade, que decorre do fato de se estar incluído no processo sem ter condições de explicá-lo senão por hipótese, é a de distinguir que "muitas ações políticas se devem a necessidades internas de caráter organizativo ligado a uma necessidade de dar coerência ao partido, ao grupo social ou a uma sociedade" (Q. 7, 24, p. 872). Trata-se de considerar as forças políticas em presença e sua função no contexto conjuntural, ou seja, da “avaliação do grau de homogeneidade, de autoconsciência e de

4 Gramsci indica a leitura de $O 18$ Brumário de Luiz Bonaparte, os escritos sobre a Questão Oriental, Revolução e Contrarrevolução na Alemanha, A Guerra Civil em França e outros escritos menores. Tais escritos "permitem entender melhor a metodologia histórica marxista" (Q. 7, p. 871). 
organização alcançado pelos vários grupos sociais" superando a fase econômico-corporativa de organização política (Q. 13, p. 1583).

Para as classes subalternas, a "tarefa essencial é aquela de empenharse sistemática e pacientemente a formar, desenvolver e tornar sempre mais homogênea, compacta e consciente de si” a força da qual se faz parte. A ação eficaz depende dessa permanente preparação e é nesse contexto que assume significado o trabalho da teoria e a apreensão do significado amplo da educação (Q. 13, p. 1588).

A questão fundamental é precisamente compreender a realidade a partir da identificação das contradições, tanto no modo como se apresentam, quanto no movimento pelo qual se constituem. A "afirmação de que o marxismo é uma nova filosofia, independente, é a afirmação da independência e da originalidade de uma nova cultura em encubação", cujas condições de desenvolvimento se encontram na transformação da sociedade capitalista (Q. 4, 3, p. 425). Se relacionarmos o conceito de subalternidade com o conceito de transformismo ou cooptação dos dirigentes, agregado ao processo de educação como adaptação ao contexto social pela formação do imaginário social, podemos dizer que elaborar uma nova concepção de mundo e uma nova cultura torna-se uma das funções mais difíceis a realizar.

\section{A ampliação do uso do conceito de "subalterno" por tendências pós-modernas}

A difusão da obra de Gramsci no mundo possibilitou a apropriação do conceito "subalterno" e a ampliação dos seus significados a partir da situação econômica, política e cultural contemporânea. Uma destas leituras foi efetuada pelo grupo indiano denominado Subaltern Studies, vinculando sua interpretação com outras leituras que denominamos pós-modernas.

Os dois pressupostos das leituras que limitam ou quebram as possibilidades da crítica são: colocar a cultura como elemento central de construção das sociedades e entender que a fragmentação se justifica pela diferença e pela pluralidade dos sujeitos envolvidos. Esses pressupostos permitem identificar a subalternidade nas mais variadas formas que ela assume na contemporaneidade, como raça, etnia, gênero, mas não permitem superá-la porque excluem do discurso a luta de classes.

Conforme Galastri (2014, p. 49), a posição pós-moderna, por meio da "justificação da pluralidade e da multiplicidade, acaba por preconizar uma situação política e social que mantém os grupos subalternos exatamente 
como tais, na subalternidade, desagregação e marginalidade histórica”. Pode-se identificar várias formas de subalternidade na sociedade moderna e o próprio Gramsci o faz quando se dirige à família na Sardenha para falar da educação de Edmea, ou quando se refere à condição da mulher na implantação do modelo industrial fordista, ou ainda para entender as várias formas de marginalização que ocorreram na história antiga e medieval. Mas sempre com as dimensões da luta de classes, sem a qual qualquer leitura se insere no horizonte ideológico que se quer contestar.

Entender a diferença fundamental entre o pensamento de Gramsci e as novas apropriações do conceito "subalterno" implica explicitar as bases teórico-metodológicas que orientaram a análise de Gramsci da situação política e cultural da Itália do início do século XX. Como acentuamos, Gramsci recorre ao conceito "subalterno" no contexto de luta de classes, o que significa conhecer a realidade, identificar suas contradições e as causas que as geraram, para poder transformar a realidade.

Ressaltar a atualidade do conceito "subalterno" implica evidenciar as várias formas que submetem os indivíduos na sociedade moderna, inclusive (e principalmente) as inconscientes. Edmundo Dias (2012) fala em "captura da subjetividade", mas sempre no horizonte da luta de classes.

Como acentua Del Roio (2007, p. 64), "dizer que a cultura e a política estão em toda parte da vida social” incluindo a economia, não significa o "mesmo que negar a determinação em última instância da reprodução da vida material dentro do complexo de determinações que compõem a totalidade”. Economia, política e ideologia se articulam dialeticamente na composição das relações de hegemonia.

Os fundamentos teórico-metodológicos da filosofia da praxis não podem ser esquecidos ou ignorados na leitura de Gramsci, porque se corre o risco de fazer uma interpretação equivocada dos seus escritos. A questão de fundo que mobiliza a escrita de Gramsci nos Cadernos do Cárcere é ainda a luta operária pelo socialismo, por novas condições sociais e políticas, luta que implica um processo de educação tanto pelas vias oficiais quanto por instituições específicas do movimento operário. Política e cultura se articulam na necessidade de superar as formas de dominação ideológica, que aprisionam a subjetividade dos trabalhadores, por um esforço continuado de autoeducação, de organização política e construção da identidade de classe.

O termo "subalternos" amplia a noção de proletariado e campesinato, incluindo na noção de classe todos que, na sociedade capitalista, vivem 
alguma forma de exploração do trabalho e alguma forma de subordinação social, política e cultural, mesmo que inconsciente. Vinculado aos conceitos de ideologia e concepção de mundo, pode ser estendido aos próprios intelectuais que atuam como 'funcionários' da hegemonia (todos os que, de um modo ou de outro, na função que exercem, contribuem para a manutenção da ordem instituída); são intelectuais, mas são subalternos, porque oriundos das classes trabalhadoras e das classes médias, atuam em defesa dos interesses dominantes. Dessa perspectiva, a problemática levantada em $A$ Questão Meridional pode ser entendida como a base da reflexão gramsciana dos Cadernos do Cárcere sobre os intelectuais.

Ainda retomando Del Roio (2007, p. 65), o "marxismo de Gramsci se desenvolve em paralelo a um novo meridionalismo" pensado tanto a partir do desenvolvimento industrial setentrional quanto das consequências da guerra para a vida dos trabalhadores. Gramsci alimentou-se da leitura de autores como Sorel, Rosa Luxemburg, Lenin e Trotski, com um estudo aprofundado de textos fundamentais de Marx, para explicitar o significado e o alcance da filosofia da praxis enquanto teoria das contradições e base fundante da compreensão da luta de classes para os trabalhadores.

O "espirito de cisão", conceito retomado de Sorel, se consolida na explicitação da sociedade capitalista como um conjunto de relações de forças, cujo contexto precisa ser conhecido para criar as possibilidades de luta pela hegemonia. Para tanto, a educação das classes trabalhadoras assume grande importância enquanto caminho para a autonomia e a identidade de classe. Ao mesmo tempo em que valoriza todas as formas de educação para os trabalhadores, Gramsci critica a escola formal italiana e aponta seus limites, critica a ingerência da Igreja católica no sistema de ensino, mostra os interesses ocultos nas políticas públicas exaradas por Gentile, ou seja, elucida todos os caminhos possíveis para a formação política dos trabalhadores e para a construção de uma nova ordem social e política.

Gramsci efetuou uma leitura da história das classes subalternas da perspectiva das contradições que perpassam os fatos históricos, com o objetivo de esclarecer essas classes quanto à sua situação social e política e quanto às tarefas a realizar, na necessidade de formar uma vontade coletiva, ou seja, de unificar-se como classe e identificar-se como classe unificada. Uma questão política que implica um processo continuado de educação que Gramsci tentou, inclusive, viabilizar na criação de Revistas, jornais, grupos de estudos, formação por correspondência. 
Conforme Del Rio (2006, p. 322), por ocasião de sua militância política Gramsci tinha um projeto ambicioso de educação; o "material pedagógico da escola de partido deveria ser composto por opúsculos tratando das questões elementares do marxismo", deveria explicitar as condições concretas da realidade econômica e política italiana.

O relativo sucesso da escola de L Ordine Nuovo, em 1920, pode ser explicado pelo vinculo existente entre movimento e processo educativo, cuja implicação mais forte é a possibilidade de o educador ser educado pelo movimento, um movimento conjunto de autoeducação das massas e de progresso intelectual coletivo. O limite foi o envolvimento de poucos e não de todo o movimento e de um partido, o que debilitou a capacidade de elaboração teórica coletiva (DEL ROIO, 2006, p. 322).

Nos Cadernos do Cárcere, a educação do educador reaparece na função do Estado e, principalmente, na importância para as classes subalternas de formar os seus próprios intelectuais e de fazer o inventário de sua história, a fim de superar a fragmentação de sua concepção de mundo e de conhecer-se para além do que lhe dá a conhecer a classe dominante. $\mathrm{O}$ conhecimento se apresenta, para Gramsci, como um instrumento de poder e de dominação para os dominantes e como via de emancipação para os subalternos ou dominados. 


\section{CAPÍTULO \\ A Educação no CONTEXTo da Hegemonia, DA IDEOLOGIA E DA LINGUAGEM}

Ao abordar a questão da educação pretendemos explicitar o significado da leitura de Gramsci ante as grandes transformações políticas e culturais que caracterizam este início do século XXI. Embora seus escritos sejam contextualizados e o capitalismo tenha hoje novas configurações, as contribuições de Gramsci para entender a educação são muito importantes, na medida em que se voltam para redefinir a questão das relações de hegemonia e seus pressupostos ideológicos enquanto consolidam a dominação fundando-a na obediência passiva. A educação perpassa a questão da hegemonia, a formação e superação de ideologias e tem uma importância fundamental na apropriação dos códigos de construção de projetos racionais. Os projetos, assim como as ideologias, se materializam na vida cotidiana por meio da linguagem. Pensar de modo autônomo e expressar claramente as ideias tem grande significado na luta política.

Dessa perspectiva, retomamos alguns aspectos da crítica ao sistema parlamentar no contexto da democracia burguesa, sustentados pela separação formal entre economia e política, esta construída a partir de uma estrutura jurídica que permite dar à ideologia uma dimensão desmesurada nas imagens de participação política e de igualdade dos indivíduos, para explicitar o significado da educação. O contexto da estrutura do Estado serve de base para entender tanto os limites do sistema parlamentar na democracia burguesa quanto os limites das políticas públicas educacionais diante da escassa representatividade que as classes populares alcançam no interior deste sistema.

Em seguida, abordam-se as formas de domínio que se efetivam na educação, ainda entendida no seu sentido amplo, ou seja, como formação dos indivíduos para um determinado modelo de sociedade. Gramsci aborda várias situações em que a educação pode se apresentar como um dos mecanismos de assimilação das relações de poder vigentes e de consolidação da dominação, principalmente por mecanismos ideológicos. Neste contexto, as 
características ideológicas de manuais que garantem a formação no exército, na Igreja e no sistema carcerário italiano.

Retomamos ainda o discurso ideológico conservador e seus desdobramentos no processo educativo das classes subalternas a partir de uma falsa ideia de neutralidade cientifica e de uma verdade universal pretensamente expressa por este ideário. Tem-se que partir de dois pressupostos: 1) a historicidade do pensamento e suas origens práticas, que implicam que a verdade é histórica; 2) a divisão da sociedade em classes sociais antagônicas e a desigualdade social implicam que toda manifestação teórica parte de uma perspectiva de classe. Neste contexto, toda verdade que se acredita eterna e absoluta precisa ser desmistificada, mostrando seu caráter histórico e seu valor provisório.

Finalmente, a partir do entendimento da luta de classes e das novas dimensões que esta assume, cabe abordar a função emancipatória da educação para as classes subalternas, a partir da articulação entre política e educação.

\section{A estrutura parlamentar na democracia burguesa e as políticas públicas educacionais}

Estranhem o que não for estranho. Tomem por inexplicável o habitual. Sintam-se perplexos ante o cotidiano. Tratem de achar um remédio para o abuso, mas não esqueçam de que o abuso é sempre a regra (BRECHT, 1982, p. 15).

Como explicitamos no primeiro capítulo, Gramsci destaca os limites do sistema parlamentar no contexto da democracia burguesa a partir de alguns pressupostos como a formação do senso comum, do individualismo voltado para a apropriação do lucro e da estrutura partidária voltada para o processo eleitoral. A questão de fundo que determina a forma do sistema parlamentar é o modelo de capitalismo que se implanta, ou seja, no caso da Itália, o processo conservador que caracterizou a unificação do Estado tendeu a deixar à margem os trabalhadores em geral, principalmente os camponeses do Sul. O Parlamento representava os grupos dominantes, legitimados pelo sufrágio (embora restrito) que os elevou ao poder. Neste contexto, as instituições permaneciam frágeis ante possíveis formas de resistência, embora estas também se fragilizavam por falta de uma organização unificadora; deste modo podiam ser combatidas, principalmente por um mecanismo desmobilizador que se tornou comum na política italiana e conhecido como transformismo. Desta perspectiva, a tendência era manter 
as contradições sociais e reduzir os movimentos sociais ao nível primitivo de corporativismo, "no sentido moderno da palavra", ou seja, nos limites das funções econômico-corporativas e não no âmbito mais elevado da consciência política (Q. 14, p. 1743).

No Caderno 10, a propósito do Risorgimento, Gramsci acentua que essa se tornou uma característica das revoluções burguesas europeias do século XIX, a partir de alianças políticas e conciliações entre setores da burguesia com a aristocracia feudal a fim de fazer frente ao movimento operário. As formulações de reformas graduais se tornam comuns evitando, assim, explosões revolucionárias radicais e violentas, como as que aconteceram na França. Tais reformas sociais, geralmente determinadas pelo alto, serviam para modernizar o aparelho de Estado e conservar as classes feudais no aparato governativo (Q. 10, p. 1358). O transformismo se caracteriza pela absorção das eventuais lideranças dos trabalhadores, desmobilizando assim seus movimentos políticos.

Os limites do sistema parlamentar também se colocam a partir de sua função no âmbito da democracia burguesa liberal, organizada em torno de um aparato jurídico que se sedimenta na separação entre forma e conteúdo, ou seja, da perspectiva legal, todos são iguais perante a lei, porém, enquanto a lei não se refere às contradições e desigualdades sociais que caracterizam uma sociedade dividida em classes, a lei não atinge igualmente todos os indivíduos. Entretanto, a separação entre formal e real funciona como mecanismo ideológico e educativo, na medida em que gera a ilusão de igualdade.

O direito não exprime os interesses de toda a sociedade, mas sim da classe dominante, "que 'impõe' a toda a sociedade aquelas normas de conduta que estão mais ligadas à sua razão de ser e ao seu desenvolvimento" (Q. 6, p. 773); o direito, na estrutura do Estado moderno, contribui para a consolidação das relações de hegemonia, visto que sua atividade abrange tanto a sociedade política quanto a sociedade civil, ou seja, o direito atua no âmbito da coerção e da formação do consenso na orientação da conduta de cada indivíduo que não queira sofrer penalidades. A função máxima do direito "é pressupor que todos os cidadãos devem aceitar livremente o conformismo" porque, sendo todos iguais, todos podem aspirar a tornarse dirigentes ou a ascender socialmente. "Este caráter educativo, criativo e formador do direito foi pouco esclarecido por certas correntes intelectuais", tratando-se de um "resíduo do espontaneismo e do racionalismo abstrato", com base num determinado conceito de natureza humana (Q. 6, p. 773-774). 
Interrogar-se sobre o caráter educativo do direito implica entender a força da ideologia na formação do modo de pensar coletivo ou do conformismo social ao qual todos são adaptados; desta forma, o direito atua para a acomodação das classes subalternas ao contexto da hegemonia vigente, bem como à estrutura da democracia burguesa e seu sistema parlamentar. Na medida em que os subalternos limitam suas ações pelas normas legais escritas pelos dirigentes, "conformam-se" (ou adaptam-se) a uma determinada situação que é pressuposta e que delineia seu imaginário não permitindo avançar além dos limites legais. O direito torna-se, então, uma condição para a manutenção da ordem vigente, um condicionador que funciona como uma miragem a delimitar a ação política dos subalternos e a mantê-los na subalternidade.

Esta questão implica mostrar os limites da ideia de igualdade que sustenta o sufrágio universal, na medida em que a desigualdade social instaurada torna essa igualdade uma miragem, ou seja, existe apenas no imaginário social para garantir uma estrutura política desigual. Cabe acentuar que Gramsci não faz essas críticas para desqualificar o sufrágio universal, que foi uma conquista histórica importante, mas para mostrar seus limites no contexto da democracia burguesa; a participação igualitária no sistema representativo é ilusória e tolhe ao homem comum "aquela infinitésima fração de poder que ele possui no decidir sobre o curso da vida estatal” (Q. 13, p. 1624-1625).

Os números têm apenas "um simples valor instrumental, que dão uma medida e uma relação e nada mais. E o que se mede? Mede-se precisamente a eficácia e a capacidade de expansão e de persuasão das opiniões de poucos, das minorias ativas, das elites, das vanguardas, etc.” (Q. 13, p. 1625). O que precisaria ser mais importante que os números é o projeto econômico e social compartilhado, a consciência crítica a determinar os caminhos a seguir. $\mathrm{O}$ aspecto restritivo do sufrágio universal se encontra tanto no fato de direito ao voto a apenas alguns setores da sociedade quanto no ideário liberal que se consolida no senso comum nas crenças na igualdade e na liberdade individual, instrumento mistificador que gera a crença de participação efetiva no processo eleitoral. Este ideário se reforça a partir da estrutura dos partidos políticos que, em geral, se organizam não para cumprir projetos e programas, mas para vencer eleições e legislar em nome dos interesses que financiam suas campanhas.

$\mathrm{O}$ funcionamento do parlamento se adequa à estrutura do Estado no contexto da sociedade capitalista, primeiro, porque não consegue exercer 
as suas funções efetivamente democráticas, ou seja, no interesse de toda a sociedade, porque a própria função representativa fica distorcida no contexto de uma sociedade desigual. Gramsci coloca a questão de procurar saber se "parlamentarismo e regime representativo se identificam e se não existe a possibilidade de uma solução diversa" tanto do parlamentarismo quanto do regime burocrático, com uma nova forma de representatividade (Q. 14, p. 1708).

A questão sobre os limites dos regimes representativos no contexto da sociedade burguesa supõe explicitar que Gramsci tem no seu horizonte a possibilidade de uma forma mais democrática de exercício do poder, como vivenciou na experiência dos Conselhos de fábrica e como defende, no curso dos cadernos, a emancipação intelectual dos grupos subalternos. Os Conselhos concretizaram uma experiência de vida coletiva e de organização dinâmica que articulava, produção, política e educação, entendendo-se que a liberdade individual não se efetiva no individualismo burguês, mas na prática política e na vida coletiva acompanhada pela formação de um pensamento coletivo articulado. No âmbito da organização política dos trabalhadores a educação que relaciona dialeticamente teoria e prática é aquela que pode assegurar o desenvolvimento da personalidade individual a partir do processo de construção da vida coletiva por meio da qual o indivíduo se transforma convivendo com os outros as mesmas experiências.

As observações acima nos permitem mostrar o caráter restritivo das políticas públicas educacionais, que Gramsci evidencia na sua crítica à reforma Gentile. O contexto da estrutura do Estado, que Gramsci define como educador, serve de base para esclarecer os limites do sistema parlamentar na democracia burguesa e seus desdobramentos nas políticas públicas educacionais voltadas para a formação das classes subalternas.

A partir dos pressupostos que sustentam o sistema parlamentar na democracia burguesa, na medida em que se aprofundam as desigualdades sociais, diminuem as possibilidades de participação efetiva das classes subalternas na estrutura política e seu voto serve apenas para referendar as relações de poder vigentes e a permanência de representantes dos grupos conservadores no legislativo. Esses grupos legislam em favor da conservação das relações de poder e do sistema instituído, fato que se reflete nas políticas educacionais. Gramsci constata essa situação na realidade italiana do início do século XX na comparação entre a antiga lei Casati e a reforma Gentile:

A eficácia educativa da velha escola média italiana, como a antiga lei Casati a havia organizado, não se devia procurar (ou negar) na vontade 
expressa de ser ou não escola educativa, mas no fato de que a sua organização e seus programas eram a expressão de um modo tradicional de vida intelectual e moral, de um clima cultural difuso em toda a sociedade italiana por tradições antiguíssimas. [...]. Se não se levam em conta estas condições, criticar os programas e a organização disciplinar da escola quer dizer menos que nada (Q. 12, p. 1543).

Quando as políticas educacionais expressam as condições reais de vida da sociedade, conseguem efetivar projetos e superar crises, porque a participação ativa de alunos e sociedade acontece somente se a escola estiver vinculada à vida e responder aos interesses dos grupos sociais que a frequentam. Gramsci acentua a importância da lei Casati, apesar de esta lei expressar um modo tradicional de vida, na forma como se possibilitava às classes subalternas o acesso às condições de produção de um pensamento autônomo, por meio das disciplinas do currículo. Por exemplo, o "estudo gramatical das línguas latina e grega, unido ao estudo das literaturas e histórias políticas respectivas, eram um princípio educativo" porque contribuíam para explicitar elementos constitutivos da vida e da cultura nacionais (Q. 12, p. 1543).

A concepção pedagógica de Gramsci supõe entender as relações de força que se efetivam em relações de hegemonia, no contexto da qual a escola assume importância na medida em que esta instituição pode articular a formação geral com o ensino profissional, gerando a possibilidade de uma disciplina argumentativa e científica como solução a longo prazo (Q. 28, p. 2330-2331).

A questão de fundo era que a escola não deveria estar voltada a formar visando finalidades práticas imediatas, mas sim dedicada ao "desenvolvimento interior da personalidade, a formação do caráter pela absorção e assimilação do passado cultural da civilização europeia moderna”. Gramsci valoriza inclusive a mecanicidade da aprendizagem dessas línguas, como modo de formar "hábitos de disciplina, de exatidão, de compostura até mesmo física, de concentração psíquica”, enfim, de elementos da formação individual que se pode adquirir somente pela "repetição mecânica de atos disciplinados e metódicos” (Q. 12, p. 1544) ${ }^{1}$.

Estas colocações reforçam a importância da disciplina no processo educativo escolar que, acompanhada de hábitos de trabalho enquanto

1 Gramsci pergunta se um estudioso seria capaz de ficar sentado horas seguidas em processo de pesquisa se não tivesse sido disciplinado na infância, se 'não tivesse assimilado por meio de coerção mecânica, os hábitos psicofísicos apropriados' para, agora, exercer sua profissão (Q. 12, p. 1544). Estas colocações se ampliam no Caderno 22, sobre Americanismo e Fordismo. Abordamos a questão da disciplina em Schlesener (2009). 
atividade teórico-prática no seu conjunto, "criam os primeiros elementos de uma intuição do mundo liberada de toda magia e bruxaria”, condições para o futuro desenvolvimento de uma concepção histórica e dialética do mundo (Q. 12, p. 1541). Supor que este tipo de formação dependa de políticas públicas bem formuladas evidencia a importância da ação dos parlamentares e da participação política consciente das classes subalternas.

A retirada do currículo do estudo da gramática normativa, como aconteceu com a Reforma Gentile, retira das classes populares a possibilidade de ter o aprendizado da língua culta e de sua história e tradições, ou seja, de ter conhecimentos importantes para a sua formação política. A "gramática normativa que, somente por abstração pode ser considerada separada da linguagem viva”, pode fazer apreender a organicidade de uma língua determinada e criar uma "atitude espiritual que torna capaz de orientar-se no ambiente linguístico” (Q. 29, p. 2349).

Excluir a gramática normativa do currículo significa, portanto, restringir as possibilidades de conhecimento para as massas populares e, consequentemente, aumentar as distâncias já existentes entre as classes sociais, visto que as crianças filhas das classes dominantes já aprendem a língua culta no cotidiano da conversação com os pais. Na atitude de Gentile "há muito mais política do que se acredita”, há "o reacionarismo da velha concepção liberal, há um 'deixar fazer, deixar passar' que não é justificado, como era em Rousseau” (Q. 29, p. 2349).

Esta aproximação da concepção liberal com Rousseau identificada na proposta de Gentile é criticada por Gramsci, principalmente porque centrada na espontaneidade da criança. Da perspectiva dialética, "cada geração educa as novas gerações e este processo se apresenta como uma luta contra os instintos ligados às funções biológicas elementares, uma luta contra a natureza, para dominá-la e criar o homem” adaptado à sua época. A espontaneidade é problemática porque a criança acumula percepções e imagens desde que nasce e essas informações se tornam complexas com o aprendizado da linguagem, que as organiza de forma lógica (Q. 1, p. 114). Sem uma orientação precisa, as possibilidades da criança de aprendizagem e de conhecimento se limitam consideravelmente.

Gentile retirou a gramática normativa do currículo da escola italiana, mas defendeu a permanência do ensino religioso que, para Gramsci, se apresenta como a "renúncia (tendenciosa) a educar o povo", de acordo com aquela concepção tradicional de que a religião é a filosofia da infância 
e o povo, como as crianças, precisa ser mantido em sua fase primitiva de compreensão (Q. 11, p. 1367). Do ponto de vista da leitura de Gramsci, a questão da educação no sistema escolar implica a conformação do aluno aos interesses sociais, mas também a sua formação para a emancipação individual e social, visto que se trata das classes trabalhadoras.

Embora Gramsci esteja analisando as condições políticas e sociais da Itália do início do século XX, a situação brasileira neste início do século XXI parece ainda mais conservadora e atrasada que aquela realidade, principalmente se lembrarmos que parlamentares se elegem porque são religiosos e praticam atos de intolerância religiosa no interior do Congresso nacional. Esta situação ainda não se traduziu em políticas educacionais, embora não estejamos distantes disso.

A partir do conceito amplo de educação aqui evidenciado, passamos para a consideração das formas de domínio que perpassam o processo educativo, desde o nascimento da criança, sendo a escola um dos momentos de consolidação das relações de domínio e controle social. Importante salientar que a sociedade vive relações que, muitas vezes, são contraditórias e essa contradições, que se renovam no interior do sistema escolar, podem ser identificadas e transformadas em motivo de ações inovadoras. Tudo depende da proposta de trabalho do professor e do material pedagógico que dispõem para desempenhar essa tarefa.

\section{As formas de domínio que se efetivam pela educação}

O despertar iminente é como o cavalo de madeira dos gregos na Troia dos sonhos (BENJAMIN, 2009, p. 437).

Partimos de uma afirmação de Gramsci sobre a educação anotada no Caderno 1: a 'escola' ou seja, a "atividade educativa direta, é somente uma fração da vida do aluno, que entra em contato com a sociedade" formando critérios a partir destas fontes "[...]'extraescolares', que são muito mais importantes do que comumente se acredita" (Q. 1, p. 114). A educação, portanto, tem uma dimensão política por fazer parte do processo de organização social e de formação do comportamento de acordo com os objetivos e finalidades do projeto econômico e social em curso, entendendo-se política em sentido amplo, a partir da divisão da sociedade em classes sociais antagônicas. Neste contexto, a educação pode se apresentar como um dos mecanismos de assimilação das relações de poder vigentes e de consolidação das formas de domínio. Gramsci acentua esse fato em carta de 11 de abril de 1927: 
Eu julgava que duas obras-primas concentravam a experiência milenar dos homens no campo da organização de massa: o manual do cabo e o catecismo católico. [...]. Cabe acrescentar agora o regulamento carcerário que encerra verdadeiros tesouros de introspecção psicológica (GRAMSCI, 1975d, p. 74).

Poderíamos acrescentar a cartilha, as apostilas e todo o material didático que se utiliza como recurso de aprendizagem nas escolas. Ao lado desses instrumentos, as teorias pedagógicas que os motivam, a própria disciplina exercida a partir da autoridade e do conhecimento do professor, problema que Gramsci aborda no curso de suas cartas e escritos. E Gramsci, na sua perspectiva educativa, considera alguns meios disciplinares (que, no fundo, são coercitivos) importantes no processo pedagógico. A disciplina é importante na aquisição de hábitos e de comportamento, principalmente nos primeiros anos da educação escolar, quando a criança precisa ser iniciada no conhecimento e na vida social. A disciplina não deve tolher as tendências e criatividade da criança, mas deve servir para desenvolvê-las.

As formas de domínio passam pelo adestramento do corpo na adequação ao processo produtivo, fato que Gramsci acentua no Caderno 22, na sua abordagem do taylorismo-fordismo, quando mostra como a racionalização do processo produtivo, acompanhada das transformações tecnológicas e organizativas, exige um dispêndio específico da força de trabalho e uma disciplina do gesto, com uma forma específica de uso da capacidade intelectual do trabalhador, como parte de sua formação.

Já no primeiro parágrafo do Caderno 22 Gramsci elenca uma série de pontos para abordar ao longo do caderno e verificamos que a maioria, senão todos, implicam uma forma coercitiva de formação, no sentido de adaptação do homem às necessidades do trabalho no modo de produção capitalista: a mudança da estrutura econômica visando redefinir a acumulação e distribuição do capital financeiro, a questão sexual, a racionalização da composição demográfica (controle da natalidade) na Europa, a questão jurídica, a dos altos salários na indústria fordista, a psicanalise como forma de coerção moral exercida sobre os indivíduos (Q. 22, p. 2140).

Essas questões assumem enorme relevância quando se trata de refletir sobre a educação e sobre a escola. A eficácia política da ideologia se apresenta no modo como se abordam os assuntos no processo de aprendizagem. Palavras como ordem, liberdade, sexualidade, etc., se forem apresentadas sem o seu significado histórico, ou seja, se forem abordadas como se fossem naturais, reforçam as formas de dominação vigentes. Gramsci apresenta um 
exemplo esclarecedor quando se refere à ideia de ordem: a "ordem presente se apresenta como algo harmoniosamente coordenado", expressando a "imobilidade estática" que exclui toda a dinâmica da vida (GRAMSCI, 1978c, p. 5). Quando um conceito se naturaliza, perde-se a compreensão de sua historicidade e a ideia adquire grande força de conservação, tornando-se verdade absoluta e eterna. Tudo o que se contrapõe a essa ideia cristalizada passa a ser considerado erro; perde-se a dimensão do movimento da vida e se tem dificuldade de aceitar o diferente ou mesmo o contraditório.

Esses pontos trazem implícita a questão ideológica no contexto das relações capitalistas de produção e de sociabilidade, na medida em que ocultam o caráter de classe do conhecimento. Poderíamos acrescentar a legislação que regulamenta a estrutura familiar, a formação religiosa, o controle do tempo e a sua distribuição ao longo da vida, o tratamento do idoso, etc., em suma, todas as formas sociais que determinam a formação e o modo de vida desde o nascimento até a morte.

A questão da educação sexual foi tratada por outros autores na historia da filosofia moderna. O silenciamento sobre o corpo e a percepção ou sobre as diferenças com relação à sexualidade no processo educativo são formas veladas de censura e de controle que marcam a subjetividade da criança e suas capacidades de expressão ${ }^{2}$.

Gramsci (Q. 22, p. 2150), no Caderno 22 aborda alguns aspectos da questão sexual e de sua repressão no contexto do desenvolvimento das sociedades, principalmente no tratamento da mulher e dos idosos, concluindo que "não se pode desenvolver o novo tipo de homem exigido pela racionalização da produção e do trabalho" sem que se regulamente e se racionalize também o instinto sexual.

Neste contexto, a questão de gênero se vincula à sexualidade da mulher e sua função de reprodução no âmbito de relações econômicas voltadas para a acumulação do capital, que determinam o relacionamento sexual: a esta questão vincula-se a da "formação de uma nova personalidade feminina" pela qual a mulher precisa alcançar "sua real independência em face do homem, bem como um novo modo de conceber a si mesma e a sua função nas relações sexuais” (Q. 22, p. 2149). Se pensarmos que Gramsci acentua

2 Como exemplos, citamos Beauvoir (1983) recorda sua infância e a sua admiração por sua família, depois de tanto controle, deixá-la morar sozinha em Paris, compreendendo, mais tarde, que havia interiorizado o controle. Também Foucault (1977), a partir de outro paradigma, acentua as graves consequências que o controle e a disciplina autoritários geram no processo de formação do homem moderno. 
essa necessidade no início do século XX, tem uma concepção avançada para o seu tempo.

Essa questão é fundamental da perspectiva educativa, visto que a história da indústria vem acompanhada por um processo continuado "doloroso e sangrento, de sujeição dos instintos” a normas e hábitos de ordem, que visam "formas sempre mais complexas de vida coletiva" que, no contexto do industrialismo, são necessárias para o maior rendimento da força de trabalho. A coerção brutal para a afirmação do "domínio de um grupo social sobre todas as forças produtivas da sociedade" tem sido recorrente na história. A “seleção ou 'educação' do homem adequado aos novos tipos de civilização" a partir das necessidades das novas formas de produção e de trabalho, aconteceu com o emprego de brutalidades inauditas" eliminando os mais frágeis ou os que resistem ao processo de absorção. E "quando a pressão coercitiva é exercida sobre toda a sociedade, [...] desenvolvem-se ideologias puritanas", por meio das quais se estabelece a "forma exterior da persuasão e do consenso ao uso intrínseco da força” (Q. 22, p. 2160-2161). Quando o resultado é alcançado, ou seja, quando se interioriza o comportamento, não se torna mais necessária a pressão.

A educação repressiva no âmbito do processo social se estende para a escola enquanto formadora de hábitos e continuadora da adaptação do indivíduo aos interesses da sociedade. Compreender e superar esta situação implica criar, a partir da organização política dos grupos subalternos, um novo contexto ideológico, uma nova concepção de mundo, uma nova ética no contexto de novas relações de hegemonia.

Por todas as observações acima, entende-se que Gramsci não se coloca contra esse processo educativo, não que defenda a coerção, mas acentua que toda mudança social exige algum tipo de pressão sobre os homens no sentido de adaptá-los ao novo. Conforme Remo Bodei (1997, p. 183):

O problema da disciplina certamente varia com base na direção na qual tende, ainda que ela contenha em si um gérmen perigosíssimo que mata $o$ senso crítico, a inteligência e a vontade de quem é constrangido a praticá-la. O crer e o obedecer submetendo-se a uma disciplina aceita, não representa necessariamente para Gramsci uma forma de 'servidão voluntária'.

Compreender a nova noção de disciplina proposta por Gramsci implica entender sua necessidade na produção de um novo projeto social e político que tenha no horizonte uma nova concepção de mundo e de uma efetiva democracia. Entretanto, as possibilidades de controle social são fortes e constituem um verdadeiro problema para definir a educação. Os limites 
entre coerção e disciplina são frágeis e, se relacionados com a questão da ideologia enquanto absorção de ideias que se traduzem em comportamentos, tem-se que perguntar também se a persuasão não traz em si um elemento de coerção.

A formação de uma nova sociabilidade se apresenta como um processo difícil e contraditório, que as classes subalternas precisam enfrentar e, para tanto, precisam superar todas as formas de obediência e submissão que lhe são impostas no contexto do modo de produção capitalista e a disciplina se torna um instrumento fundamental para a realização deste projeto.

A escola que Gramsci chama de tipo "humanista”, precisa desenvolver no indivíduo a cultura e o "poder fundamental de pensar de saber orientarse na vida” (Q. 12, p. 1530). Essa característica da escola tradicional foi-se perdendo com as novas profissionalizações inseridas sem um planejamento claro e preciso nas políticas públicas italianas; para Gramsci, a "crise do programa e da organização escolar, ou seja, da orientação geral de uma política de formação dos modernos quadros intelectuais" era um dos aspectos da crise orgânica vivida naquele momento. A implantação da escola técnica colocou em debate o principio de formação cultural geral "com base na tradição greco-romana"; a tendência geral era abolir a escola "formativa" ou manter "um exemplar reduzido para uma pequena elite" não destinada a exercer funções profissionais (Q. 12, p. 1531). Gramsci identificava, na Itália do início do século XX, uma tendência que seria geral no mundo capitalista com a implementação de novas tecnologias de produção.

Ao decidir sobre programas e organização escolar, o Estado exerce o seu poder de controle do sistema escolar conforme os objetivos da estrutura econômica e produtiva, no sentido de formação de mão de obra, antes que formar indivíduos pensantes. Essa forma externa de domínio se completa com a determinação de programas e de material didático, como orientação ideológica preferencial ${ }^{3}$. Esse modelo de escola insere-se no contexto educativo mais amplo, que é o de preparar as classes trabalhadoras para os objetivos da produção.

Ao lembrar do manual do cabo, do catecismo católico, muito importante na Itália, e o controle exercido no sistema carcerário, Gramsci acentua

3 Tomemos como exemplo os livros de história e como apresentam a questão da revolução: por que se valoriza tanto a Revolução Francesa e nem sequer se cita a Revolução de 1848 ou a comuna de Paris? Porque a primeira iniciou o processo de construção da ordem burguesa, enquanto a segunda e a terceira foram revoluções operárias por uma República Social ou pelo socialismo, contra a ordem burguesa, ou seja, trata-se de uma leitura que não é neutra e sim serve para legitimar o conflito que instaurou a ordem burguesa e omitir as novas formas de luta de classes produzidas a partir desta ordem. 
as formas de educação repressiva e de formação ideológica que podem ser articuladas ao sistema escolar, embora este seja mais flexível no processo de formação. No contexto da teoria política gramsciana, todo processo de educação tem uma característica ideológica fundamental para a conservação da ordem instituída. A defesa de uma escola que contemple a cultura geral visa a formação das classes trabalhadoras para a sua emancipação política no contexto da luta de classes.

\section{A noção gramsciana de ideologia e o discurso conservador}

As ideias dominantes de uma época são sempre as ideias da classe dominante (MARX, 1978, p. 111).

Estamos vivendo um momento de retorno das ideias mais conservadoras a respeito do que seja o pensamento e sua expressão da realidade efetiva. Trabalhos acadêmicos defendidos e aprovados diante de bancas que se dizem de renome defendem a neutralidade de suas abordagens, contra um discurso que denominam ideológico e doutrinador. Cabe-nos explicitar, a partir dos escritos de Marx e de Gramsci, o que se efetiva de fato como ideológico, a fim de rebater a ideia de um pensamento neutro. Numa sociedade dividida em classes sociais antagônicas, marcada pela exploração da força de trabalho e uma concentração fabulosa de rendas, que acentua desmesuradamente a desigualdade social, é fantasmagórica a defesa da neutralidade axiológica.

Da perspectiva da filosofia da praxis, neste contexto social a noção de verdade universal é abstrata, porque toda verdade é histórica e expressa um ponto de vista de classe e, como acentua Marx em A Ideologia Alemã, a "classe que dispõe dos meios de produção material dispõe igualmente dos meios de produção intelectual” (MARX, 1976, p. 55-56). Retomando a leitura gramsciana, a produção intelectual elaborada por pensadores que se constituem uma elite representante da classe dominante, serve para manter e ampliar as relações de domínio que se efetivam como hegemonia. $\mathrm{E}$ os meios de produção intelectual também servem para concretizar tais relações, veja-se o que dissemos a propósito da linguagem e dos meios de comunicação de massa.

A questão da ideologia merece ser retomada aqui porque a educação escolar, aliada ao senso comum veiculado nos meios de comunicação de massa, além da formação recebida na família e nas igrejas, em geral prepara 
as crianças para a vida passiva característica dessa estrutura social. As perspectivas de abordagem da ideologia colocadas por Gramsci são variadas, indo desde a crítica a uma noção de objetividade exterior (tão cara hoje, aos conservadores), até a inversão da noção de verdade, passando pela explicitação da historicidade de toda produção teórica, para mostrar que a ideologia e a doutrinação estão da parte dos dominantes e não dos dominados.

Tendo como pressuposto a historicidade do pensamento, toda verdade que se acredita eterna e absoluta apresenta-se como um mito a ser desmistificado. No movimento histórico, todo pensamento tem origens práticas e expressa um valor provisório. Isso é importante no desenvolvimento de uma teoria pedagógica e no processo de aprendizagem, para não se cair em doutrinação, como acusam os conservadores sem perceber que, eles próprios, no momento em que afirmam a verdade absoluta de sua posição, estão sendo doutrinadores. Doutrina que se mantém ainda no século XXI é o positivismo que, assimilado pelo senso comum, dificulta qualquer processo de aprendizado que aborde o conhecimento de outra perspectiva.

Adquirir clareza do conjunto de relações sociais nas quais se está inserido e superar níveis de compreensão dessa realidade e perceber que fazemos parte de um grupo social em movimento, superando interesses imediatos para entender o movimento histórico em suas contradições não é uma tarefa fácil. Superar um conhecimento que se funda na lógica formal para apropriar-se de um pensamento dialético, cujo conteúdo de verdade se encontra na articulação entre teoria e prática, articulação esta permanentemente renovada no movimento da história, exige esforços inusitados.

A filosofia da praxis coloca a questão do que é a verdade e demonstra que esta não é um fato apenas lógico, mas sim um fato essencialmente político, ou seja (e aqui o que assusta os conservadores), é no enfrentamento dos conflitos sociais, no confronto das forças em luta, que se constrói a verdade que expressamos em teoria, mas que nasce da prática e da tentativa de subverter esta prática. E esta verdade é sempre parcial e provisória, feita de luzes e sombras, a partir de perspectivas porque é uma verdade histórica, centrada na luta de classes, cuja divisão precisa ser superada para que se possa, enfim, construir uma verdade universal.

Dessa perspectiva, toda filosofia é também uma ideologia, inclusive a filosofia da praxis. Mas é uma ideologia com um teor de verdade diverso do positivismo, do idealismo ou de qualquer outra metafisica: trata-se de uma filosofia que visa a esclarecer os subalternos dos grilhões invisíveis 
que os prendem, de modo consciente e inconsciente, e que os reduzem a seres passivos e obedientes; visa a esclarecer para que possam emancipar-se e conquistar a liberdade. As ideologias dominantes, ao contrário, servem como "instrumentos práticos de domínio político sobre o restante da sociedade", para submeter ao trabalho e ao modelo social vigente; sua força de dominação se encontra na sua fingida neutralidade, na sua capacidade de obscurecer as relações reais mistificando-as e escondendo os elos de submissão que existem na realidade e que servem para manter a ordem instituída. Nesse contexto, como acentua Gramsci, as ideologias não são ilusões nem aparências, mas possuem um conteúdo político que se traduz na forma como se tornam instrumentos de direção política, ou seja, "são fatos históricos reais, que é necessário combater e explicitar na sua natureza de instrumentos de domínio, não por razões de moralidade, etc.” (para os conservadores a moralidade é anterior e superior à política), "mas precisamente por razões de luta política”, para tornar os subalternos intelectualmente independentes (Q. 10, p. 1319).

Resumindo, em uma sociedade dividida e profundamente desigual como a sociedade capitalista, o pensamento expressa, queiramos ou não, interesses de parte da sociedade, porque ela se encontra dividida em classes sociais antagônicas. A diferença é que o pensamento hegemônico, porque da parte das classes dominantes, mascara a realidade, transforma a sua visão parcial em visão universal e submete os governados convencendo-os dessa universalidade. A filosofia da praxis, enquanto teoria das contradições, é expressão da realidade dos grupos subalternos e visa a esclarecer esses grupos sociais da realidade da dominação para que tenham acesso aos instrumentos do conhecimento para a sua emancipação e para a sua efetiva liberdade.

Retomemos, agora, a questão da linguagem: o poder mistificador e de ocultamento dos interesses por meio da ideologia se manifesta no uso da linguagem. O discurso "politicamente correto", traduz-se em uma forma de censura, que se torna, no curso do tempo, autocensura, ou seja, valores e princípios que se escondem em conceitos são assimilados formando o senso comum e ocultando as contradições do real. Como acentua Dias (2012, p. 36-37), como exemplo: "apagar formas ofensivas" tidas como "racistas" nos escritos como Monteiro Lobato, funciona para "ocultar as diferenças reais".

A pretexto do pagamento da dívida histórica da escravidão - dívida dos dominantes - passa-se a uma culpabilização histórica dos próprios dominados (a culpa é genericamente dos brancos, mesmo daqueles tão 
oprimidos quanto os negros descendentes (ou não) de escravos. Mudamse as palavras, muda a realidade? Palavras passam a ser substituídas: não mais negros, mas afrodescendentes. Políticas focalizadas (que em nada alteram a dominância burguesa) passam a ser formas compensatórias daquelas culpas genéricas ao contrário das políticas universais que são apresentadas como incapazes de resgatar as diferenças históricas e criminosamente construídas (DIAS, 2012, p. 37).

Trata-se de uma forma de educação pelo silenciamento ou ocultamento das contradições reais que caracterizam a história da dominação burguesa. ${ }^{4}$ A educação pelo silêncio funciona sempre como uma forma de censura que culpabiliza de modo generalizado, como acontecia, ainda em meados do século XX, com a educação sexual das crianças. Na família nada se dizia e nada se explicava porque "era feio", "era mau" e as crianças, que não aprendiam em casa, iam aprender na rua, correndo sérios riscos em seu processo de educação.

A censura foi tema dos escritos políticos de Gramsci, tanto no contexto da Guerra de 1918 quanto com referência ao fascismo. Em Rabiscos, publicado em Scritti Giovanili (GRAMSCI, 1975, p. 340-42), nosso autor acentua as dificuldades de encontrar um equilíbrio na escrita entre "as necessidades da própria sinceridade e as agressões irracionais da censura", que entende como um abuso de autoridade de quem, detendo por um momento um poder, quer deixar seu vestígio, mesmo que seja o de sua injustiça.

E o resultado de qualquer ação censora constante e recorrente resulta em interiorização do controle pela parte censurada que, no caso de Gramsci (1975, p. 342), jornalista, procurava produzir um discurso capaz de elidir o censor. A "caneta continua a produzir rabiscos, esperando, porque sente que esta barbárie (a confusão nos critérios, o arbítrio, o abuso são barbáries) se esgotara na própria raiva”.

Na educação escolar a adaptação ao processo social acontece por meio do aprendizado das palavras e da explicitação de seus significados; ditas ou veladas, as palavras podem encobrir mais do que desvelar sentidos, cumprindo uma grande função na consolidação de uma ideologia. Num processo de aprendizagem que vise a emancipação do aprendiz, a compreensão da palavra precisa ir além do seu significado abstrato, para atingir sua significação política e concreta, isto é, precisa ser entendida em sua dimensão

4 Nesse contexto, a linguagem nao explicita o sentido, mas mistifica a realidade ocultando os conflitos que a constituem, $\mathrm{O}$ discurso politicamente correto não diz pobre, miserável, faminto, mas "indivíduo em condições de insustentabilidade"; no lugar de prisioneiro, encarcerado, se diz "privado de liberdade". Trata-de de um discurso que mistifica as relações sociais, a censura e a dominação. 
ideológica, no teor de verdade que ela expressa e para quem este significado interessa, porque nenhum discurso é neutro em uma sociedade de classes.

Educar para a emancipação intelectual, com futuros desdobramentos na prática do aprendiz, implica mostrar os limites do discurso dominante na sua pretensão de verdade absoluta e universal, a fim de possibilitar ao educando a formação de um pensamento autônomo e independente. Se traduzirmos educando por grupos subalternos, significa dar-lhes os instrumentos de emancipação política a partir do teor de verdade da filosofia da praxis enquanto teoria das contradições.

Realizar esta tarefa implica persistência e metodologia; Gramsci faz algumas observações sobre a questão do método de aprendizagem, que podem ser importantes para o trabalho do professor na escola ou do dirigente no partido:

No ensino da filosofia dedicado não a informar historicamente o discente sobre o desenvolvimento da filosofia passada, mas para formá-lo culturalmente, para ajudá-lo a elaborar criticamente o próprio pensamento e assim participar de uma comunidade ideológica e cultural, é necessário partir do que o discente já conhece, de sua experiência filosófica (após ter demonstrado que ele tem uma tal experiência, que ele também é um 'filosofo' sem o saber) (Q. 1, p. 148).

O ponto de partida é o senso comum, ou seja, as "informações soltas e fragmentárias”, sem qualquer preparação metodológica ou crítica que fazem parte do pensamento do discente ou do subalterno (Q. 1, p. 148). Sabe-se que o senso comum se compõe do que existe de mais variado e contraditório entre si, ou seja, de todas as informações que o indivíduo acumula ao longo de sua vida, desde o que recebe da tradição por meio da família e da religião até o conhecimento cientifico mais avançado em dados fragmentados e simplificados que recebe pelos meios de comunicação de massa. Esse conjunto lhe fornece as condições de entender a política, a ética e a moral, a partir do ideário mais recente das classes dominantes. Iniciar desse ponto significa partir das aparências para mostrar seus limites e contradições, entendendo-se o ato pedagógico como pressupondo uma opção política. Criticar o nosso senso comum significa tornar nossa concepção de mundo "coerente e unitária elevando-a ao ponto atingido pelo pensamento mundial mais desenvolvido”. (Q. 10, p. 1371).

A questão política expressa-se no fato de pressupor que a sociedade se divide em classes sociais antagônicas que sustentam a "existência de governantes e governados, dirigentes e dirigidos. Toda a ciência e a arte 
políticas se baseiam neste fato primordial e irredutível” (Q. 15, p. 1752) e que garantem a conotação política de todas as relações vividas na sociedade.

\section{A educação como forma de emancipação para os trabalhadores}

A história pedagógica demonstra que cada classe que se preparou para a conquista do poder, tornou-se apta mediante uma educação autônoma. A primeira emancipação da servidão política e social é a do espírito (GRAMSCI, 1982, p. 643).

A educação perpassa os escritos de Gramsci e a citação acima foi retirada de um escrito de 1916 intitulado A primeira pedra, a propósito de um Congresso realizado em Milão sobre os problemas da educação popular. Conforme o artigo, o evento reuniu pedagogos de diversas tendências, além de fisiólogos, economistas e parlamentares para discutir como deveria ser a educação do povo na escola italiana. E muitas coisas foram ditas e muitas promessas feitas naquela ocasião. Gramsci aproveita o momento para colocar as bases de uma nova educação escolar que realmente interesse aos trabalhadores, visto que as classes dirigentes "querem impor às grandes massas de trabalhadores rurais e urbanos um plano de educação que forme um estado de consciência e uma mentalidade conforme os interesses dominantes", o que parece "muito natural e toda a história das instituições pedagógicas a confirma” (GRAMSCI, 1980, p. 642).

Gramsci acentua que esta questão é tão importante que, na Itália, a "escola foi disputada por duas forças diversas: a Igreja e a Maçonaria" (se pensarmos na nossa realidade, os interesses do capital e a privatização da educação). O povo, porém, tem outros interesses e precisa de uma escola laica, de educação civil; o "programa de educação do proletariado deve ser formulado e efetivado por órgãos que o próprio proletariado constituiu em defesa de seus próprios interesses". O problema da educação é um problema político e "um problema de classe e só pode ser resolvido do ponto de vista de classe". E termina este belo artigo conclamando: Temos que tirar das mãos das classes dirigentes a educação dos trabalhadores, como o primeiro e decisivo passo para uma nova era (GRAMSCI, 1980, p. 643).

Trata-se de uma questão fundamental para a autonomia das classes trabalhadoras, como o primeiro passo para a emancipação política. A partir dessa leitura, critica-se Gramsci nos Escritos de militância política por valorizar excessivamente a cultura e o processo educativo como condição para a revolução. Esse tema retorna com toda a sua força nos Cadernos, 
principalmente nos escritos referentes à crítica às pedagogias que sedimentam a escola burguesa e nas breves observações sobre a escola única. Cabe acentuar ainda a importância que Gramsci atribui ao trabalho político dos intelectuais e também à formação do partido.

A questão da educação implica uma organização partidária interna que viabilize a permanente participação de todos nas decisões numa relação dialética que permita a qualquer membro se tornar dirigente, ou seja, Gramsci redefine a noção de democracia no interior do partido acentuando que este não deve seguir o modelo parlamentar burguês, mas deve criar uma nova experiência democrática que possibilite às massas atingir um nível superior de autonomia política.

Toda a análise gramsciana da política é perpassada pela questão da educação. Do mesmo modo, o seu trabalho de historiador, tem como pano de fundo a formação das classes trabalhadoras para a sua luta política e cultural. A leitura gramsciana da história moderna evidencia a construção da hegemonia pela burguesia ascendente em sua capacidade política e ideológica de absorver as demais classes sociais envolvendo-as em seu projeto. Neste movimento de construção da hegemonia, a política e a cultura transformam-se em instrumentos de domínio: “[...]'Estado' significa especialmente direção consciente das grandes multidões nacionais”; isso implica "um 'contato' sentimental e ideológico com tais multidões e, em certa medida, simpatia e compreensão de suas necessidades e exigências”. Esse contato se efetiva por meio da cultura, da arte, da literatura, ou seja, pela atuação dos intelectuais. Na Itália, ocorre a "ausência de uma literatura nacional-popular", o que demonstra a "ausência de preocupação e de interesse por estas necessidades e exigências, deixando o 'mercado' literário aberto a influências de grupos intelectuais de outros países”. [...] “Assim o povo italiano se apaixonou, por meio do romance histórico-popular francês [...] pelas tradições francesas, monárquicas e revolucionárias”, ou seja, "apaixona-se por um passado que não é seu, serve-se na sua linguagem e no seu pensamento de metáforas e referências culturais francesas, etc., é culturalmente mais francês que italiano" (Q. 23, p. 2197).

Em se tornando instrumentos de hegemonia, a política e a cultura assumem novas dimensões no contexto da luta de classes, assim como a própria ideologia enquanto prática de poder. Conforme Burgio (2003, p. 99), na comparação com as sociedades anteriores, na sociedade moderna a "violência migra das relações de comando político para as relações de produção, na medida em que estas tornam-se fundamento da ordem social”. 
Podemos acrescentar que, no âmbito das relações econômicas, a violência se mascara com apoio da ideologia, que forma a nova individualidade. Nas sociedades antigas, o escravo ou o servo de gleba sabiam que eram explorados em seu trabalho. $\mathrm{O}$ assalariado do mundo moderno acredita que é justamente recompensado pelo seu trabalho. Esta mudança de percepção do trabalhador tem como base a forma como o modo de produção capitalista controla o tempo de trabalho e, com ele, o tempo de vida e o modo de pensar de toda a sociedade, ou seja, o modo como se articulam o econômico, o político e o ideológico por meio da formação da subjetividade. $\mathrm{O}$ fato de se fundar na produção e consumo de mercadorias faz com que, na sociedade capitalista, o tempo seja reduzido aos objetivos da produção e da acumulação do capital; como diz o ditado popular, tempo é dinheiro. A serviço deste novo modo de ser está a educação formal, a estrutura urbana, a vida familiar e a cultura em geral ${ }^{5}$.

Um tema relevante para explicitar a questão da educação perpassa a reflexão de Gramsci sobre os caracteres italianos, entre eles a ideia generalizada de que os italianos são individualistas. E Gramsci explicita os significados possíveis de individualismo e seus desdobramentos na ação política. "Não participar ativamente da vida coletiva" não significa, necessariamente, não ser partidário, mas pode significar que, ao "partido e ao sindicato 'modernos', assim como foram elaborados pelo desenvolvimento das forças produtivas mais progressivas, 'preferem' formas organizativas de outro tipo", como as máfias, as camorras, etc. "Qualquer nível ou tipo de civilização tem o seu 'individualismo', ou seja, uma posição e uma atividade peculiares dos indivíduos singulares nos seus quadros gerais”. Esta situação depende tanto da inserção do indivíduo na estrutura econômica quanto de sua formação política e cultural. Na Itália, a "razão deste estado de coisas tem origens históricas distantes" e se esta situação ainda se mantém, a responsabilidade é dos grupos dirigentes nacionais (Q. 6, p. 815) ${ }^{6}$.

\footnotetext{
5 Abordamos a questão do tempo na sociedade capitalista no livro Os tempos da História - leituras de Walter Benjamin. Brasília: Liber Livro, 2011. Basicamente os capítulos II e VI.

6 "Não participar ativamente da vida coletiva, isto é, da vida estatal [...] significa, talvez, não ser 'partidário', não pertencer a nenhum grupo constituído? Significa o 'esplêndido isolamento' do indivíduo singular, que conta somente consigo mesmo para criar a sua vida econômica e moral? De modo nenhum. Significa que ao partido político e ao sindicato econômico 'modernos', assim como foram elaborados pelo desenvolvimento das forças produtivas mais progressivas, 'prefere-se' formas organizativas de outro tipo, precisamente do tipo 'submundo', ou seja, os grupelhos, as camorras, as máfias, sejam populares ou ligadas à classe alta, Qualquer nível ou tipo de civilização tem o seu 'individualismo', ou seja, uma posição e uma atividade peculiares dos indivíduos singulares nos seus quadros gerais. [...] A razão deste estado de coisas tem origens históricas distantes e da manutenção desta situação é responsável o grupo dirigente nacional” (Q. 6, p. 815).
} 
Entendemos que, de qualquer parte que abordemos os escritos do cárcere, a questão de fundo é sempre a educação na sua perspectiva geral: o problema que Gramsci coloca a partir desta análise do significado de individualismo é saber "se tal situação pode ser superada com métodos de centralização estatal (escola, legislação, tribunais, polícia) que tendam a nivelar a vida" conforme a formação de um tipo nacional (Q. 6, p. 815). Ou seja, a educação pode ser efetuada pelos meios estatais em função dos objetivos hegemônicos ou do projeto de sociedade das classes dominantes.

Gramsci acentua a complexidade desse processo e esclarece: uma nova construção social deve "surgir de baixo, na medida em que todo um estrato nacional, o mais baixo econômica e culturalmente, participe a um fato histórico radical" que envolva "toda a vida do povo e ponha cada um, brutalmente, diante das próprias responsabilidades inderrogáveis”. O erro histórico da classe dirigente italiana foi ter "impedido sistematicamente que um tal fenômeno acontecesse no período do Risorgimento" e de ter agido no sentido da continuidade e "manutenção de uma educação cristalizada, do Risorgimento em diante” (Q. 6, p. 816). Em outras palavras, o ponto central para as classes trabalhadoras é sempre a revolução e essa se apresenta como fruto de um processo educativo.

Desta perspectiva, a educação faz parte de todo o processo de organização política e de formação de uma nova concepção de mundo. Aos limites e possibilidades da escola formal, Gramsci acrescenta todas as instituições educativas possíveis a partir dos movimentos sociais organizados pelas classes subalternas. Neste contexto, trata-se de considerar que:

a) a educação realiza-se na vida e a escola é apenas uma de suas instâncias; para Gramsci, a educação realiza-se ao longo da vida enquanto um processo de conhecimento de si e do mundo por meio do qual construímos a nossa identidade e nos inserimos no movimento da vida social e política. A educação formal em geral visa a responder as exigências materiais e simbólicas necessárias para a manutenção do processo de dominação do capital, de acordo com padrões determinados de ensino e aprendizagem, sempre renovados e ampliados para responder às necessidades da produção e não do relacionamento e da realização dos indivíduos.

b) a escola existe para cumprir os objetivos colocados pela estrutura social (formar para o trabalho), embora as contradições sociais permitam ampliar os caminhos de aprendizagem; a escola tem a função de formar para o trabalho numa sociedade marcada pela divisão social, limite no qual atua a escola 
pública. Explicitar as contradições e as correlações de forças que permeiam o social se apresenta como o grande desafio, que exige a inserção de novos métodos de ensino e de formação continuada dos docentes, a fim de criar as condições de uma formação integral. Formar novas subjetividades capazes de reconhecer suas raízes sociais e culturais a fim de compreender a sua inserção no mundo, esse poderia ser o objetivo primordial da escola pública.

A partir desse contexto, quais as condições sociais e políticas para concretizar o ideal emancipatório que se propõe como objetivo? Para Gramsci, na realidade italiana do início do século XX, esse objetivo se encontrava no horizonte das lutas das classes trabalhadoras, visto que educação e emancipação são conceitos que, no contexto do materialismo histórico, deveriam ser análogos ou vinculados em relação de semelhança e completude: a educação deveria ser sempre emancipadora. Mesmo nos limites da sociedade capitalista, as classes subalternas não podem abrir mão da educação formal, simplesmente porque, para enfrentar a luta pela hegemonia, precisam entender as formas de dominação a que estão submetidos e isso só é possível pelo acesso ao conhecimento historicamente produzido.

O projeto social moderno, das classes dominantes, direciona as políticas educacionais voltadas para a educação popular a fim de cumprir os objetivos de consolidação da hegemonia. Se a educação popular é tão importante para as classes dominantes a ponto de ser o "traço mais característico ao qual todos os outros estão subordinados" e motivo de disputa entre Estado e Igreja na Itália, imaginemos para as classes subalternas (Q. 7, p. 930). Assim como no processo de manutenção da hegemonia burguesa, todo o processo de organização política visando a conquista da hegemonia pelas classes subalternas precisa ter como suporte a educação.

\section{A educação escolar, a linguagem e a ideologia}

A escola única, intelectual e manual, tem a vantagem de colocar a criança em contato ao mesmo tempo com a história humana e com a história das 'coisas' sob o controle do professor (Q. 1, p. 114).

A epígrafe acima conclui uma breve reflexão sobre as "origens históricas precisas de alguns princípios das pedagogias modernas”, evidenciando os modos como tais ideias se aplicam no processo educativo, muitas vezes de forma equivocada porque não se tem em conta as condições históricas e as polemicas que geraram as teorias. Um exemplo de Gramsci são as ideias de Rousseau, que originariamente "foram uma reação violenta à escola e aos métodos pedagógicos dos jesuítas”, o que pode ser considerado um progresso. 
Mas posteriormente as interpretações tomaram outros rumos dando "lugar a curiosas involuções (nas doutrinas de Gentile e de Lombardo-Radice). A espontaneidade é uma destas involuções” (Q. 1, p. 114). Já assinalamos que a escola deve assumir uma parte do processo educativo, que acontece ao longo da vida, desde o nascimento até a morte e as demais instituições sociais tem uma grande importância neste processo. Gramsci defendia a educação enquanto um processo formativo que exige disciplina tanto de quem aprende quanto de quem ensina, disciplina entendida como orientação apontando direções e não como controle autoritário.

Ao abordar as várias possibilidades experimentadas por pedagogias modernas, a questão de fundo, para Gramsci, é "criar um tipo de escola que eduque as classes instrumentais e subordinadas a uma função dirigente na sociedade", ou seja, trata-se de formar um coletivo e não apenas desenvolver alguma capacidade individual (Q. 9, p. 1183). Pensar na formação coletiva implica acentuar o caráter político do processo educativo e a importância, para as classes subalternas, de universalizar conhecimentos adquiridos, a fim de que superem a fragmentação de seu modo de pensar (Q. 11, p. 1366-8). E, principalmente, entender que a escola é um dos espaços de formação crítica, na medida em que a filosofia da praxis ou a dialética, como metodologia e critério de interpretação da realidade, possibilitam esse tipo de formação.

Nesta perspectiva, uma abordagem dialética vai muito além das teorias pedagógicas positivistas e mesmo das pedagogias crítico-reprodutivistas, porque a escola, embora tenha objetivos limitados na sociedade capitalista, abre possibilidades de superar estes limites e criar condições de acesso com qualidade ao conhecimento historicamente produzido, essencial para consolidar a personalidade.

Para tanto, precisamos renovar a escola por dentro, questionando currículos, métodos de ensino, fragmentação do conhecimento, objetivos das políticas públicas que retratam projetos de governo e não projetos de sociedade; seria a tarefa inicial no Brasil, a fim de recuperar as condições de qualidade do ensino ministrado. Essa é uma tarefa que em algum momento precisa ser enfrentada tendo como pressuposto a compreensão do todo para manter as possibilidades de uma crítica. Para Gramsci, "as ideias são grandes enquanto são exequíveis”, ou seja, enquanto tornam clara uma situação real e enquanto "mostram concretamente o processo de ações através das quais uma vontade coletiva organizada traz à luz estas relações" e, trazendo à luz, as criam ou as destroem, substituindo-as (Q. 8, p. 1050). 
A importância da educação escolar da perspectiva que aqui abordamos se apresenta na possibilidade de o aluno se apropriar da linguagem e dos códigos de argumentação, para pensar de modo crítico, desconstruindo o discurso ideológico dominante. A aprendizagem da linguagem se torna essencial quando se entende que a hegemonia se consolida pela formação do consenso passivo e que esse poder das classes dominantes se ampliou de forma inusitada com a inserção das novas tecnologias de comunicação. As classes populares, para se organizarem na luta pela hegemonia, precisam se reconhecer no movimento contraditório de construção da sociedade e, para isso, necessitam dominar a linguagem para enfrentar o dominador no seu terreno.

A linguagem é importante para organizar e expressar ideias inovadoras. A educação é sempre política, assim como a linguagem. Numa sociedade desigual não se pode educar sem tomar partido, ou seja, sem mostrar aos alunos as contradições que permeiam a vida da sociedade. Todas as decisões a respeito da estrutura escolar, o currículo, as disciplinas a serem ensinadas ou a serem retiradas do currículo implicam posições políticas que, evidentemente, não aparecem na formulação das propostas curriculares, mas as sustentam, porque os currículos expressam objetivos que são, indiretamente, expressão de interesses de classe.

Defender uma escola sem partido ou sem ideologia é defender uma educação despolitizada que esconde a política mais conservadora que se possa imaginar porque, em nome da neutralidade do conhecimento, se apresenta a seletividade de caráter político conservador. Todo o material que serve para formar o aprendiz tem conteúdo ideológico e tudo o que se diz ilumina e esconde, ao mesmo tempo, a realidade abordada.

A história contada nas cartilhas e livros escolares está cheia de equívocos dessa natureza, com omissões gravíssimas de grandes conflitos sociais que resultaram de movimentos violentos de dominação e de exploração dos mais fracos. A questão agrária no Brasil, um dos problemas cruciais que enfrentamos há séculos, sequer é tocada; falar em latifúndios parece um tabu, quando o próprio Censo Agropecuário denomina média propriedade aquela que tem em torno de 2000 hectares, ou seja, extensões maiores que alguns países da Europa. Identifica-se, a partir da implementação das políticas neoliberais uma concentração de terras ainda maior, com invasões de territórios indígenas, cujos habitantes são massacrados na defesa de suas 
terras7 . A maior concentração ocorreu principalmente no governo FHC: a "área titulada pelas propriedades com mais de 2000 hectares aumentou de 112 para 124 milhões”. Com a implementação do agronegócio, ainda no governo FHC "dois milhões de trabalhadores rurais foram desempregados e 960 mil sítios com área inferior a 100 hectares foram extintos" (FRANCO, 2005, p. 33).

Na história do Brasil encontramos muitos "contos da carochinha", como o descobrimento do Brasil, os conflitos de Canudos e do contestado, Tiradentes, etc. O contestado, por exemplo, teve como pano de fundo a disputa de terras por empresas estrangeiras que aqui aportaram para construir uma ferrovia com o objetivo de extrair riquezas naturais e colonizar o Sul do Brasil. As populações ali residentes resistiram em defesa de suas pequenas propriedades e, como o movimento nasceu espontaneamente, foi envolvido por ideologias religiosas, que acabaram prevalecendo na imagem histórica que se fez desses camponeses, como místicos amalucados. Essa imagem prevaleceu, escondendo os reais interesses econômicos e imperialistas que, no curso de cem anos, transformaram uma grande floresta de araucárias em grandes extensões de plantio de pinus, com uma população de camponeses extremamente empobrecida.

Como acentua Saviani (2003, p. 75), pedagogia “significa não apenas a condução da criança, mas a introdução da criança na cultura”. Apresentar meias verdades como se fossem verdades universais é o que existe de mais desonesto com a criança e o adolescente, uma violência dissimulada que os torna indivíduos despolitizados e incapazes de decidir autonomamente sobre questões sociais e políticas, pelas quais indiretamente são responsabilizados. O resultado é bem conhecido na atualidade brasileira, com um congresso pleno de religiosos defendendo políticas arbitrárias, com indivíduos manifestando-se pelo retorno da ditadura militar e, ao mesmo tempo, defendendo a paz e outras atitudes contraditórias entre si que, se tivessem tido boas aulas de história na escola, certamente não estariam tomando. Esta situação demonstra, antes de tudo, o estrondoso fracasso da educação escolar no Brasil.

\footnotetext{
7 A implementação do neoliberalismo a partir da década de 1990 ampliou as condições de concentração fundiária no Brasil: conforme Pires (2012, p. 21-2), os próprios dados do IBGE confirmam a disparidade na distribuição da terra: as pequenas propriedades "com menos de 10 hectares - representam $47 \%$ do contingente de estabelecimentos agrícolas no país, enquanto a área ocupada por eles é de apenas 2,7\% do total"; as propriedades "com menos de 100 hectares são cerca de $90 \%$ do total, ocupando uma área em torno de $20 \%$ \%; as propriedades "com área maior ou igual a cem hectares representam apenas 9,6\% do total", mas ocupam "78,6\% da área dedicada a atividade" com "mais de mil hectares" correspondem a "0,9\% do total, mas ocupam 43 \%" da área cultivável.
} 
A escola é um espaço de aprendizagem importante para as classes trabalhadoras porque permite o acesso aos códigos de raciocínio e de elaboração do saber; sem esses instrumentos torna-se muito difícil sair do imediatamente dado na prática cotidiana ou, como acentua Gramsci, superar no âmbito da política os limites do econômico corporativo ou a fase inicial de espontaneidade das explosões insurrecionais.

Cabe acentuar que a superação da barreira entre intelectuais e classes populares tem que passar necessariamente pela educação e pela escola, o que se depreende das palavras:

O elemento popular 'sente', mas não compreende nem sabe; o elemento intelectual 'sabe', mas não compreende e principalmente não sente. Os dois extremos são, portanto, o pedantismo e o filisteismo de um lado, a paixão cega e o sectarismo do outro. [...]. O erro dos intelectuais consiste em crer que se possa saber sem compreender e especialmente sem sentir e estar apaixonado, ou seja, que o intelectual possa sê-lo apenas se distinto e destacado do povo (Q. 4, p. 451-2).

Sentir e compreender como o povo implica unir-se a ele, fazendo o trabalho de explicação de uma situação histórica determinada, "vinculando-o dialeticamente às leis da história, a uma concepção de mundo superior e cientificamente elaborada, o 'saber'[...]” (Q. 4, p. 452). O lugar privilegiado para essa relação é a escola e o que motiva o professor a continuar com todas as limitações que lhe são impostas pelos governos e suas políticas públicas é, precisamente, orientar o aluno e acompanhar o seu florescimento intelectual. Os olhos se iluminam quando o aluno supera os limites do positivismo e consegue perceber a realidade de modo dialético. Ensinar implica mostrar as perspectivas discordantes da realidade, desvelar sinais da grandeza do passado e seus significados em novo contexto histórico, iniciar o aluno na dimensão simbólica e política, que se concretiza num pensamento organizado.

Gramsci compara o professor ao místico, que sabe, compreende e sente, como escreve no artigo A luz que se apagou: "pensem naquilo que na Idade Media, representa o movimento franciscano diante do teologismo doutrinário da Escolástica”. O "intelecto havia matado o sentimento, a reflexão cuidadosa tinha estrangulado o ímpeto da fé". E veio "São Francisco, alma humilde, descuidada, espírito simples", que renovou a teologia e "fez renascer em cada alma a divina embriaguez”. Assim também é o professor, aquele toma pelo braço e guia; com ele a "palavra não é mais elemento

8 Tradução publicada no livro Antologia filosófica, da Secretaria da Educação do Paraná. 
gramátical a dividir em regras", mas um som, uma nota musical, poesia que "estimula nossa capacidade criativa", desperta ecos distantes do passado, revigorando o presente (GRAMSCI, 1975, p. 10-12).

A questão colocada evidencia que toda educação é ideológica, na medida em que forma o modo de pensar e de sentir. No processo de aprendizagem a direção do professor é importante, na medida em que mostra possibilidades de leitura autônoma. A ideologia permeia este trabalho e tudo o que acontece no ambiente escolar, basta ler com atenção as cartinhas e todo o material didático, a organização dos currículos, os planos de aula. Cabe utilizar desses instrumentos da melhor maneira para que as classes populares consigam, por meio desses instrumentos, acessar ao conhecimento para a sua emancipação política. 


\section{Considerações finais}

O sentido deste livro, retomando pela enésima vez a leitura de Antonio Gramsci, tem dois objetivos principais: evidenciar a centralidade da política nas análises da realidade social e mostrar como a educação perpassa os Cadernos do Cárcere no sentido de esclarecer as classes subalternas com o objetivo de possibilitar a elaboração de um projeto alternativo de sociedade. A cada nova leitura do Cadernos fica mais claro para nós que Gramsci não abandonou o propósito da época de militância política de formar a classe trabalhadora para um processo revolucionário.

Para explicitar esta nossa posição, articulamos três conceitos fundamentais na leitura de Gramsci, que são: hegemonia, ideologia e linguagem, a fim de explicitar as noções de educação e de cultura. Ao longo de nosso escrito tentamos desfazer alguns mitos que se apresentam quando se trata da educação escolar, isso porque ela trabalha principalmente com a questão da ideologia e da linguagem. Um desses mitos é sobre o que é um discurso verdadeiro ou o que é a verdade. Se vivemos um movimento permanente e contraditório de relações de força a partir de uma situação histórica profundamente dividida, não existem verdades eternas, mas existe uma verdade universal que é esta: tudo é histórico. E, se a sociedade é profundamente cindida, é verdadeira a posição que admite ser de parte, ou seja, que explicita as contradições colocando-se no movimento de contradições.

Desta perspectiva, renova-se o significado de hegemonia, porque também esse conceito precisa ser entendido no contexto das relações de força, ou seja, muda conforme a perspectiva da qual o abordamos: tem um significado para o liberalismo e outro para Gramsci, que entendia existir ainda a possibilidade de subversão da praxis. Explicitar esse contexto e estas perspectivas a partir da leitura de Gramsci significa querer contribuir para entender os modos como o seu pensamento foi apropriado parcialmente pelos liberais e reformistas, assim como pelos subaltern studies. O leque pode ser ampliado na medida em que os Cadernos do Cárcere tomaram o mundo em diversas traduções. E um escrito, depois de publicado, foge das mãos do autor e, sendo a linguagem metafórica, abre a possibilidade de múltiplas interpretações. 
Tivemos o cuidado de não falar em "uso ou abuso" de interpretação do texto, porque entendemos que uma interpretação parcial não é feita de "má fé”, mas é feita, em geral, por desconhecimento do texto original completo, o que acontece muito no Brasil. A instrumentalização do pensamento de Gramsci ocorreu a partir da urgência em resolver problemas práticos sem considerar que a teoria exige tempo e paciência para a sua assimilação; teve como causa, ainda, o fato de se omitir ou de se relegar a segundo plano a articulação que Gramsci efetua entre política e cultura e a abordagem em separado destas duas instâncias altera profundamente o conteúdo do pensamento do autor. Devemos ainda acentuar que boa parte de seus escritos pré-carcerários são desconhecidos no Brasil.

Outro fator que possibilitou uma assimilação equivocada de conceitos foi o próprio caráter inacabado e problematizador de seus escritos, gerando a possibilidade de uma leitura parcial. Acrescente-se ainda que a inserção de Gramsci no Brasil se fez pela primeira edição italiana realizada por Togliatti, que se apresenta já como uma primeira interpretação dos escritos carcerários, na vertente da socialdemocracia, fator facilitador para uma leitura liberal e reformista de Gramsci. Como depositário da herança literária e política de Gramsci, herança legada ao Partido Comunista Italiano, Togliatti aceitava a linha staliniana e sua preparação da primeira publicação dos Cadernos fez-se ressentir deste posicionamento.

As dificuldades de leitura e interpretação podem ser explicadas até pelo texto de Gramsci, que acentua ser uma das características das classes subalternas o não ter organicidade em sua concepção de mundo e desconhecer os instrumentos necessários para elaborar um pensamento crítico a fim de construir um projeto alternativo de sociedade, ficam sempre a mercê dos intelectuais e de suas formas de subordinação. Os mitos de neutralidade do saber e do Estado entendido apenas como aparato governativo permitem que o exercício do poder pelas classes dominantes, seja potencializado por meio da ideologia e da linguagem, com novas dimensões a partir da inserção de novos mecanismos tecnológicos de comunicação de massa.

Essas formas de dominação que passam pela formação do consentimento, de um modo de pensar homogêneo e da própria formação da subjetividade moderna é que chamamos aqui de grilhões invisíveis com os quais precisamos romper para construir uma nova ordem social e política. É esse modo de ser que se produziu em séculos de dominação capitalista, que se amplia com novas formas de expropriação das classes trabalhadoras, com a aquiescência de sindicatos cooptados e de partidos que não 
conseguem superar os limites da estrutura parlamentar burguesa, que precisa ser rompida.

A necessidade de compreender este conjunto de articulações que formam uma nova concepção de mundo é que evidencia a importância da educação em geral e da educação escolar em particular para as classes trabalhadoras. A escola é um espaço privilegiado para iniciar a romper esses grilhões ideológicos que nos prendem e nos fazem acreditar que a dominação é natural, que a desigualdade existe porque os indivíduos têm capacidades diferentes e alguns vencem e outros perdem, porque vemos as relações sociais da perspectiva do positivismo ou do liberalismo. Ou seja, anos e anos de "histórias da carochinha" nos convenceram que o problema não é de luta de classes, mas de incapacidade individual, não é um problema de ordem social e política, mas de natureza. E há momentos em que a luta de classes se torna evidente no cotidiano (onde ela está sempre presente), nas ameaças de violência contra quem pensa diferente ou se veste de vermelho, na Babá que empurra o carrinho de bebês na manifestação de extrema direita (que nem se identifica como tal), etc. Temos que subverter esta prática e mostrar que a escravidão histórica continua em novas formas invisíveis de dominação, que agora passam pela formação de nossa subjetividade.

Se a dominação econômica se amplia com a sustentação da dominação ideológica, as lutas de classes precisam assumir o plano da representação recuperando a memória e a história das classes subalternas como base elementar da luta política. Pensamos que ela se caracteriza como a genialidade de Gramsci que, mesmo sem conhecer a teoria freudiana, parece avançar na compreensão das novas dimensões da dominação por meio da formação da subjetividade. De nossa perspectiva, é isso que torna tão importante a educação em geral e a educação escolar em particular para as classes trabalhadoras. A escola é um terreno privilegiado para as classes dominantes no sentido de preservar sua ideologia, suas experiências e sua leitura histórica para fazer com que as classes subalternas pensem e vivam conforme valores e interesses dominantes. Basta examinar o conteúdo dos manuais escolares para ver como se constroem as "mentiras eternas" (Brecht). Mas a escola é também um espaço de contradições, tanto suas quanto as trazidas do contexto social por seus alunos; conhecer e explicitar essas contradições é um caminho fértil para a elaboração de um novo saber sobre a nossa realidade histórica.

Auxiliar o discente a apropriar-se de uma nova metodologia de abordagem para compreender o real para além de suas aparências, para além 
do imediatamente dado e que os pós-modernos entendem que se deve descrever; as bases da lógica formal são importantes, mas não suficientes para isso, servindo para uma abordagem inicial, mas a elaboração do conhecimento num contexto crítico exige que se identifiquem as contradições que permeiam o processo pelo qual se constituem o social, o político e o cultural, a fim de analisar as forças que atuam na historia e nas quais estamos inseridos. Desmistificar ideias preconcebidas e consolidadas no senso comum, desnaturalizar o conhecimento, redefinir a própria política para superar a noção limitada de política de governo para entender a política como uma das instâncias da luta de classes, desmistificar a ideia positivista de objetividade fundada na inexistente ideia de neutralidade, são alguns dos objetivos para vencer os mitos que alimentam o nosso cotidiano.

Para o professor que se empenha nesta linha, é um trabalho de Sísifo, que não pode ser realizado sozinho, mas a partir da própria organização coletiva dos professores, enquanto intelectuais convencidos de seu trabalho junto às classes populares. Caso contrário, atua-se como Don Quixote, combatendo moinhos. Mesmo assim, trata-se de um trabalho muito gratificante quando começam a aparecer os resultados: entender que o real é processo e que conhecer significa atualizar permanentemente a compreensão das relações de forças no interior desse movimento transforma a visão do mundo; os olhos brilham quando o aluno entende que toda a formação social, nacional e internacional, é um conjunto de estruturas articuladas que precisamos conhecer para tomar nas mãos o nosso destino. Um destino que não é individual, mas que precisa ser coletivamente construído, ou seja, dedicado não a informar o discente sobre o desenvolvimento pontual da história passada, nem a identificar o erro nas palavras, mas sim dedicado a formá-lo culturalmente ensinando-o a elaborar criticamente o próprio pensamento a fim de integrar-se em movimentos de ação fazendo parte de uma "comunidade ideológica e cultural” (Q.1, p. 148). Pensamos que é neste sentido que a educação pode ser revolucionária ou, como dizia Gramsci, pode contribuir para subverter a praxis. 


\section{REFERÊNCIAS}

ACANDA, Jorge Luis. Sociedade civil e hegemonia. Rio de Janeiro: Ed. UFRJ, 2006.

AGA-ROSSI, Elena; ZASLAVSKY, Victor. Togliatti e Stalin - Il PI e la política estera staliniana negli archivi di Mosca. Bologna: Il Mulino, 2007.

ANDERSON, Perry. Ambiguità di Gramsci. Bari: Laterza, 1978.

ANGLANI, Bartolo. Solitudine di Gramsci: política e poética del carcere. Roma: Donzelli, 2007.

BADALONI, Nicola. Liberdade individual e homem coletivo em Gramsci. In: Instituto Gramsci, Política e história em Gramsci. Rio de Janeiro: Civilização Brasileira, 1978, p. 09-69.

. Gramsci: a filosofia da práxis como previsão. In: HOBSBAWM, Eric (Org.). História do marxismo. Rio de Janeiro: Paz e Terra, 1991, v. X, 1991.

BARATTA, Giorgio. As rosas e os cadernos: o pensamento dialógico de Antonio Gramsci. Rio de Janeiro: DP\&A, 2004.

BARATTA, Giorgio. Le rose e i quaderni - Saggio sul pensiero di Antonio Gramsci. Roma: Gamberetti, 2000.

BARATTA, Giorgio e LIGUORI, Guido (Orgs.) Gramsci: da un secolo all'altro. Roma: Riuniti, 1999.

BEAUVOIR, Simone de. Memórias de uma moça bemcomportada. Rio de Janeiro: Nova Fronteira, 1983.

BENJAMIN, Walter. Passagens. Belo Horizonte: UFMG, 2009.

BIANCHI, Álvaro. O laboratório de Gramsci. Primeira versão, n. 136, IFCH/ Unicamp, 2007.

BOBBIO, Norberto. Saggi su Gramsci. Milano: Feltrinelli, 1990. 
BODEI, Remo. Colonizzare le coscienze. Forme della politica e società di massa in Gramsci. In: VACCA, Giuseppe (Org.). Gramsci e il Novecento. Roma: Carocci, 1999.

BRECHT, Bertold. Antologia Poetica. Rio de Janeiro: Elo Ed. 1982. BROCCOLI, Angelo. Antonio Gramsci y la educacion como Hegemonia. México: Nueva Imagen, 1977.

BUCK-MORSS, S., Walter Benjamin: entre moda acadêmica e avantgarde. In: Crítica Marxista. São Paulo: n. 10, 2000.

BUCI-GLUCKSMANN, Christine. Gramsci e o Estado. Rio de Janeiro: Paz e Terra, 1980.

BUISSIÈRE, Evelyne. Il Machiavelli di Gramsci. In: Crítica Marxista, Roma: n. 6, 1991.

BURGIO, Alberto. Gramsci: il sistema in movimiento. Roma: DeriveApprodi, 2014.

BURGIO, Alberto. Gramsci Storico - una lettura dei Quaderni del Carcere. Bari: Laterza, 2003.

BUTTIGIEG, Joseph A., Il metodo di Gramsci. In: Critica Marxista n. 6, 1991.

BUZZI, A. R. La teoria política de Antonio Gramsci. Barcelona: Fontanella, l969.

CAMMETT, John M.Antonio Gramsci ele origini del comunismo italiano. 4. ed. Milano: Mursia, 2007.

CHATELET, François. Logos e Praxis. Rio de Janeiro: Paz e Terra, 1972.

CHATELET, François. O Capital e outros Estudos (Trad. E.F. Dias). Campinas: IDCH/UNICAMP, 2004.

DANIELE, Chiara (Org.) Togliatti editore di Gramsci. Roma: Carocci, 2005.

DEBRUM, Michel. Gramsci: filosofia, política e bom senso. São Paulo: Ed. UNICAMP, 2001. 
DE FELICE, Franco Revolução passiva, fascismo, americanismo em Gramsci. In: Instituto Gramsci, Política e história em Gramsci. Rio de Janeiro: Civilização Brasileira 1978.

DE JESUS, Antonio T. Educação e Hegemonia. São Paulo/ Campinas: Cortez/Ed. Univ. de Campinas, 1989.

DEL ROIO, Marcos. Os prismas de Gramsci. São Paulo: Xamã, 2005 .

DEL ROIO, Marcos. Gramsci e a educação do educador. Caderno Cedes, v. 26, n. 70, 2006, p. 311-328.

DEL ROIO, Marcos. Gramsci e a emancipação dos subalternos. Revista de Sociologia e Política, Curitiba: n. 29, 2007, p. 63-78.

DEL ROIO, Marcos (Org.). Marx e a Dialética da sociedade civil. Marilia/São Paulo: Oficina Universitária/Cultura Acadêmica, 2014.

DIAS, Edmundo Fernandes. A liberdade (im)possível na ordem do Capital - reestruturação produtiva e passivização. Campinas: IFCH/UNICAMP, 1999.

DIAS, Edmundo Fernandes. Gramsci em Turim: a construção do conceito de hegemonia. São Paulo: Xamã, 2000.

DIAS, Edmundo Fernandes. Hegemonia: racionalidade que se faz história. In: VV. AA. O Outro Gramsci. São Paulo: Xamã, 1996.

DIAS, Edmundo Fernandes. Compreender o real, demonstrar a sua inteligibilidade. In: SCHLESENER, Anita Helena e PANSARDI, Marcos Vinícius. Políticas Públicas e Gestão da Educação. Curitiba: UTP, 2006.

DIAS, Edmundo Fernandes. Política brasileira: embate de projetos hegemônicos. São Paulo: Sundermann, 2007.

DIAS, Edmundo Fernandes. Revolução passiva e modo de vida: ensaios sobre as classes subalternas, o capitalismo e a hegemonia. São Paulo: Sundermann, 2012.

DIAS, Edmundo Fernandes. Notas sobre Hegemonia. In: SCHLESENER, A. H. Filosofia, Política e Educação: leituras de Antonio Gramsci. Curitiba: UTP, 2014. 
DI BELLO, Anna (Org.). Marx e Gramsci: filologia, filosofia e politica allo specchio. Napoli: Liguori Ed., 2011.

D’ORSI, Angelo. Gramsciana: saggi su Antonio Gramsci. Modena: Mucchi Ed., 2014.

DURANTE, L. Gramsci e os perigos do cosmopolitismo. Educação em foco - Revista de Educação. UFJF, v. 5, n. 2, Set./Fev/ $2000 / 2001$.

EAGLETON, Terry. Ideologia. São Paulo: UNESP, 1997.

EAGLETON, Terry. A ideologia da estética. Rio de Janeiro: Jorge Zahar Ed., 1993.

EAGLETON, Terry. As ilusões do pós-modernismo. Rio de Janeiro: Jorge Zahar Ed., 1998.

EAGLETON, Terry. A ideologia e suas vicissitudes no marxismo ocidental. In: ZIZEK, Slavov. Um mapa da Ideologia. Rio de Janeiro: Contraponto, 1996.

EDELMAN, Bernard. A legalização da classe operária. São Paulo: Boitempo, 2016.

FERRI, Franco. (Org.). Política e História em Gramsci. (Atas do Encontro Internacional de Estudos Gramscianos - Florença, 9-1l.l2. 1977). Rio De Janeiro: Civilização Brasileira, 1978.

FINELLI, Roberto. O "pós-moderno": verdade do "moderno". In: COUTINHO, Carlos N. E TEIXEIRA, Andrea de Paula. Ler Gramsci, entender a realidade. Rio de Janeiro: Civilização Brasileira, 2003, p. 99-112.

FIORI, Giuseppe. A vida de Antonio Gramsci. Rio de Janeiro: Paz e Terra, 1979.

FIORI, Giuseppe. Gramsci, Togliatti, Stalin. Bari-Roma: Laterza, 1991.

FOUCAULT, Michel. Vigiar e punir. Petropolis: Vozes, 1977.

FRANCO, Tania Mara. Educação e ação: o novo no velho agrário. São Paulo: Expressão Popular, 2005. 
FRANCIONI, Gianni. L'Officina Gramsciana: Ipotesi sulla struttura dei "Quaderni del Cárcere”. Napoli: Bibliopolis, 1984.

FRANCIONI, Gianni. Gramsci tra Croce e Bucharin: sulla struttura dei Quaderni 10 e 11. In: Critica Marxista, Roma, 1987, n. 6, p. 19-45.

FRESU, Gianni. "Il diavolo nell'ampolla" - Antonio Gramsci, gli intellettuali e il partito. Napoli: La Città del Sole, 2005.

FRESU, Gianni. Lenin lettore di Marx. Napoli: La Città del Sole, 2008.

FROSINI, Fabio. Gramsci e la filosofia: Saggio sui Quaderni del carcere. Roma: Carocci, 2003.

FROSINI, Fabio. Filosofia e utopia nos Cadernos do Cárcere: HegelMarx-Gramsci. Educação em foco (Gramsci - 100 anos), Ed. UFJF, v. 5 , n. 2, 2000/2001, p. 95-114.

FROSINI, Fabio. A "história integral" desde a perspectiva dos subalternos: contribuição para uma teoria marxista da história. In: Crítica Marxista, São Paulo: 2013, n. 37, p. 27-46.

FROSINI, Fabio. Da Gramsci a Marx: ideologia, verità e politica. Roma: Derive Approdi, 2009.

FROSINI, Fabio e LIGUORI, Guido. Le parole di Gramsci: per un lessico dei Quaderni del Carcere. Roma: Carocci, 2004, p. 170-188.

GALASTRI, Leandro. Classes sociais e grupos subalternos: distinção teórica e aplicação política. Crítica Marxista, São Paulo: 2014, n. 39, p. 35-55.

GALEANO, Eduardo. O Livro dos Abraços. Porto Alegre: L \& PM, 1997.

GARIN, Eugenio. Con Gramsci. Roma: Riuniti, 1997.

GERRATANA, Valentino. Gramsci: problemi di metodo. Roma: Riuniti, 1997.

GERVASONI, Marcos. Georges Sorel - una biografia intellettuale. Milano: Unicopli, 1997. 
GERVASONI, Marcos. Antonio Gramsci e la Francia - dal mito della modernità alla "scienza della politica". Milano: Unicopli, 1998.

GRAMSCI, Antonio. Scritti Giovanili (191401918). Torino: Einaudi, 1975.

GRAMSCI, Antonio. Sotto la Mole (1916-920). Torino: Einaudi, 1975b.

GRAMSCI, Antonio. L'Ordine Nuovo (1919-1920). Torino: Einaudi, 1975c.

GRAMSCI, Antonio. Socialismo e Fascismo (L Ordine Nuovo, 192l-l922). Torino: Einaudi Editore, 1978a.

GRAMSCI, Antonio. La Costruzione del Partito Comunista (l923-l926). Torino: Einaudi, l978b.

GRAMSCI, Antonio. Cronache Torinesi (19l3-19l7), (a cura di Sergio Caprioglio). Torino: Einaudi Editore, 1980.

GRAMSCI, Antonio. La Cittá Futura (lol7-lol8), (a cura di Sergio Caprioglio). Torino: Einaudi Editore, l982b.

GRAMSCI, Antonio. Il nostro Marx (1918-1919). (a cura di Sergio Caprioglio). Torino: Einaudi Editore, 1982.

GRAMSCI, Antonio. L' Ordine Nuovo (19l9-1920) (a cura di V. Gerratana e A. A. Santucci). Torino: Einaudi Editore, 1987.

GRAMSCI, Antonio. La Città Futura. Torino: Einaudi, 1978c.

GRAMSCI, Antonio. Il Risorgimento. Torino: Einaudi, 1974.

GRAMSCI, Antonio. Quaderni del Carcere. Torino: Einaudi, 1978.

GRAMSCI, Antonio. Lettere dal Carere. Torino: Einaudi, 1975d.

GRAMSCI, Antonio. Lettere (1908-1926) - (a cura di A. Santucci). Torino: Einaudi, 1992.

GRAMSCI, Antonio. Antonio Gramsci e a revolução socialista: primeiros escritos (Tradução de Ana Paula Schlesener). Revista Cadernos de Pesquisa: Pensamento Educacional. V. 10, n. 24, jan.abr. 2015, p. 191-205. 
GRAMSCI, Antonio e SCHUCHT, Tatiana. Lettere (1926-1935) (a cura di Aldo Natoli e Chiara Daniele). Torino: Einaudi, 1997.

GRAMSCI, Antonio e TOGLIATTI, Palmiro. Gramsci a Roma, Togliatti a Mosca - Il Carteggio del 1926 (a cura di Chiara Daniele). Torino: Einaudi, 1999.

GRAMSCI, Antonio. Quaderni del Carcere (Edizione critica direta da Gianni Francioni) Roma: Fondazione Istituto Gramsci/Istituto della enciclopédia Italiana. Quaderni di Traduzioni (1929-1932), 2007, v. 1 e 2 .

GRAMSCI Jr. Antonio. La storia di una Famiglia rivoluzionaria - Antonio Gramsci e gli Schucht tra la Russia e l'Italia. Roma: Riuniti, 2014.

GRIGOR'EVA, Irina V., Il tema dell'Urss nei “Quaderni” gramsciani. In: Critica Marxista, Roma: N. 6, 1991, p. 29-41.

HOBSBAWM, ERIC. Era dos Extremos: o breve século XX (19141991). São Paulo: Companhia das Letras, 1995.

IANNI, Otavio. A sociedade Global. Rio de Janeiro: Civilização Brasileira, 1992.

IANNI, Otavio. Dialética e Capitalismo. Petrópolis: Vozes, 1982.

JAMESON, Friedric. Marxismo e Forma - Teorias Dialéticas da literatura no Século XX. São Paulo: Hucitec, 1985.

JOCTEAU, G. C. Leggere Gramsci. Milano: Feltrinelli, 1977.

LABICA, Georges. As “Teses sobre Feuerbach" de Karl Marx. Rio de Janeiro: Jorge Zahar Ed., 1990.

LA BOÉTIE, E. Discurso da Servidão Voluntária. São Paulo: Brasiliense, 1982.

LACORTE, Rocco. Sobre alguns aspectos da "tradutibilidade" nos Cadernos do Cárcere de Antonio Gramsci e algumas de suas implicações. Revista Educação e Filosofia, Uberlândia: v. 28, n. 55, jan./jun. 2014, p. 59-98.

LEPRE, Aurelio. Il prigioniero - vita di Antonio Gramsci. Bari: Laterza, 1998. (Já existe em português). 
LIGUORI, Guido. Gramsci conteso. Roma: Riuniti, 1996.

LIGUORI, Guido. Sentieri gramsciani. Roma: Carocci, 2006.

LOMBARDI, Giovanni. Gramsci e l'educazione dei figli. In: VV. AA. Gramsci e la cultura contemporanea II (Atti del Congegno di Cagliari, 1967). Roma: Riuniti, 1975.

LO PIPARO, Franco. Il Professor Gramsci e Wittgenstein: il linguaggio e il potere. Roma: Donzelli Ed., 2014.

LOSURDO, Domenico. Daí fratelli Spaventa a Gramsci. Napoli: La Città del Sole, 1997.

LOSURDO, Domenico. Antonio Gramsci: dal liberalismo al "comunismo critico". Roma: Gamberetti, 1997.

LOSURDO, Domenico. A luta de classes: uma história política e filosófica. São Paulo: Boitempo, 2015.

MACCIOTTA, Giorgio. Rivoluzione e classe operaia negli scritti sull'OrdineNuovo.In:VV.AA.Gramscielaculturacontemporanea II. Roma: Riuniti, 1975.

MANACORDA, Mario A. O princípio educativo em Gramsci. Porto Alegre: Ed. Artes Médicas Sul, 1990.

MANACORDA, Mario A. Marx e a pedagogia moderna. São Paulo: Cortez/Autores Associados, 1991.

MANCINA, Claudia. Rapporti di forza e previsione: il gioco della storia secondo Gramsci. In: Critica Marxista, Roma, 1980, n. 5, p. 41-51.

MARCUSE, Herbert. A grande recusa hoje. Petropolis: Vozes, 1999. MARSIGLIA, Ana Carolina G. (Org.) Pedagogia Histórico-Crítica: 30 anos. Campinas: Autores Associados, 2011.

MARX, Karl. O 18 Brumário de Luis Bonaparte. São Paulo: Abril Cultural, 1977.

MARX, Karl. Manuscritos Econômicos e Filosóficos. São Paulo: Boitempo, 1974.

MARX, Karl. Teses contra Feuerbach. In: Pensadores, São Paulo: Abril Cultural, 1974b. 
MARX, Karl. Para a Crítica da Economia Política. São Paulo: Abril Cultural, 1974c.

MARX, Karl. O Capital. Rio de Janeiro: Civilização Brasileira, 1980, $7 \mathrm{v}$.

MARX, Karl e ENGELS, Friedrich. A Ideologia Alemã. Lisboa: Presença, 1976, v.1 e II.

MARX, Karl e ENGELS, Friedrich. O Manifesto do Partido Comunista. Rio de Janeiro: Zahar, 1978.

MASTELLONE, Salvo. (Org.). Gramsci: i "Quaderni del Carcere”una riflessione politica incompiuta. Torino: UTET Libreria, 2002.

MATTEUCCI, Niccola. Antonio Gramsci e la filosofia della prassi. Milano: Giuffré Editore, 1977.

MEDICI, Rita. Gramsci e a filosofia da praxis: significado e usos do termo "popular". In: SCHLESENER, A. H. Filosofia, Política e educação - leituras de Antonio Gramsci. Curitiba: Ed. UTP, 2014, p. 35-49.

MONTANARI, Massimo. Gramsci e il Medioevo. In: VACCA, Giuseppe (Org.). Gramsci e il Novecento. Roma: Carocci, 1999.

MORDENTI, Raul. Gramsci e la rivoluzione necessaria. Roma: Riuniti, 2007.

NATOLI, Aldo. Antigone e il prigioniero. Roma: Riuniti, 1990.

NATOLI, Claudio.eTRINCIA, F.S.(Orgs.).Marxismo eLiberalismo: Una riflessione critica di fine secolo. Milano: FrancoAngeli, 1995.

NOSELLA, Paolo. A escola de Gramsci. Porto Alegre: Artes Médicas Sul, 1992. (Nova edição pela Cortez).

NOVACK, George. As origens do materialismo. São Paulo: sundermann, 2015.

ORTIZ, Renato. A consciência fragmentada (ensaio de cultura popular e religião). Rio de Janeiro: Paz e Terra, 1980.

PAGGI Leonardo. Le strategie del potere in Gramsci. Roma: Riuniti, 1984. 
PALA, Mauro (Org.). Narrazioni egemoniche: Gramsci, letteratura e società civile. Bologna: Il Mulino, 2014.

PASOLINI, Pier-Paolo. Empirismo eretico. Milano: Garzanti, 1995. PASOLINI, Pier-Paolo. Passione e ideologia. Milano: Garzanti, 1994.

PASOLINI, Pier-Paolo. Caos - Cronicas Politicas. São Paulo: Brasiliense, 1982.

PASOLINI, Pier Paolo. Escritos Póstumos. Lisboa: Moraes Ed., 1979.

PIRES, Angela Monteiro. Educação do Campo como Direito Humano. São Paulo: Cortez, 2012.

PORTELLI, Hughes. Gramsci e o bloco histórico. Rio de Janeiro: Paz e Terra, 1977.

PRISTIPINO, Giuseppe. Tradire Gramsci. Milano: Teti Ed., 2000.

RANIERI, Jesus J. Alienação e estranhamento em Marx: dos Manuscritos econômico -filosóficos de 1844 a Ideologia Alemã. Campinas: 2000 (Tese de Doutorado).

RAGaZZINI, Dario. Teoria da Personalidade na sociedade de massa - a contribuição de Gramsci. São Paulo: Autores Associados, 2005.

RAPONE, Leonardo. Cinque anni che paiono secoli - Antonio Gramsci dal socialismo al comunismo (1914-1919). Roma: Carocci, 2011.

RUIZ, E. A. Freud no "divã" do cárcere - Gramsci analisa a psicanálise. Campinas: Autores Associados, 1998.

SANTOS, J. A. O princípio da hegemonia em Gramsci. Lisboa: Vega, s.d.

SARTRE, Jean-Paul. Em defesa dos Intelectuais. São Paulo: Ática, 1994.

SAVIANI, Dermeval. Educação: do senso comum à consciência filosófica. São Paulo: Cortez/Autores Associados, 1980. 
SAVIANI, Dermeval. Política e Educação no Brasil. 5. ed. São Paulo: Autores Associados, 2002.

SAVIANI, Dermeval. Escola e Democracia. São Paulo: Cortez/ Autores Associados, 1984.

SAVIANI, Dermeval. História das Ideias Pedagógicas no Brasil. Campinas: Autores Associados, 2010.

SCHLESENER, Anita.Algumas considerações sobre a linguagem em Gramsci. Textos SEAF - ano 3, n. 4, 1983, p. 7-13.

SCHLESENER, Anita Helena. Hegemonia e Cultura: Gramsci. 3. ed. Curitiba: UFPR, 2007.

SCHLESENER, Anita Helena. Revolução e Cultura em Gramsci. Curitiba: Ed. UFPR, 2001.

SCHLESENER, Anita Helena. Antonio Gramsci e a política italiana. Pensamento, polêmicas, interpretação. Curitiba: UTP, 2005 .

SCHLESENER, Anita Helena. A escola de Leonardo: política e educação nos escritos de Gramsci. Brasília: Liber Livro, 2009.

SCHLESENER, Anita Helena (Org.). Filosofia, política, educação: leituras de Antonio Gramsci. Curitiba: UTP, 2014.

SCHLESENER, A. H. A linguagem e seu significado político e pedagógico a partir dos escritos de Gramsci. In: GOMES, V. C., SOUSA, J. R. e rabelo, J. J. (Orgs.). Gramsci, educação e luta de classes. Fortaleza: Imprensa Universitária, 2015a.

SCHLESENER, Anita Helena. Arte e Educação: breves observações sobre as leituras de Trotsky e de Gramsci sobre o futurismo. Revista InCantare, v. 6, n. 1, Jan./Jul. 2015.

SCHLESENER, Anita Helena. Os tempos da História - leituras de Walter Benjamin. Brasília: Liber Livro, 2011.

SEMENARO, Giuseppe. Gramsci e a sociedade Civil. Petrópolis: Vozes, 1999.

SILVA, T. T. (Org.). Trabalho, Educação e Prática Social. Porto Alegre: Artes Médicas, 1991. 
SPADAFORA, Giuseppe. L'Identità negativa della Pedagogia. Milano: Unicopli, 1992.

SPRIANO, Paolo. "L'Ordine Nuovo" e i consigli di fabbrica. Torino: Einaudi, 1971.

SPRIANO, Paolo. L Occupazione delle Fabriche. Torino: Einaudi, 1964.

SPRIANO, Paolo. Gramsci e Gobetti. Torino: Einaudi, 1977.

SPRIANO, Paolo. L'ultima ricerca di Paolo Spriano (i documenti segreti dagli archivi dell'Urss sui tentativi per salvare Antonio Gramsci). Roma: L'Unità, 1988.

SPRIANO, Paolo. Storia di Torino Operaia e Socialista. Dall'inizio a Gramsci. Torino: Einaudi, 1972.

STIPCEVIC, Niksa. Gramsci e i problemi letterari. Milano: Mursia, 1981.

TORTORELlA, Aldo. Consenso e libertà. In: Crítica Marxista, Roma: 1987, n. 2-3, p. 307-314.

TOSEL, André. Forza e limiti della filosofia della prassi. In: BARATTA, Giorgio e LIGUORI, Guido (Orgs.) Gramsci da un secolo all'altro. Roma: Riuniti, 1999, p. 141-159.

VACCA, Giuseppe. Gramsci e Togliatti. Roma: Riuniti, 1991.

VACCA, Giuseppe. Appuntamenti con Gramsci. Roma: Carocci, 1999.

VACCA, Giuseppe (Org.). Gramsci e il Novecento. Roma: Carocci, 1999, v. 1 e 2.

VALÉRY, Paul. Introdução ao método de Leonardo da Vinci. São Paulo: Editora 34, 2006.

VASOLI, Cesare. Il "giornalismo integrale". In: VV. AA. Gramsci e la cultura contemporanea II. Roma: Riuniti, 1975.

VV.AA. Gramsci e il Novecento. Roma: Carocci, 1999 (2 v.). 
VV.AA. Gramsci e la cultura contemporanea (Atti del Convegno internazionale di studi gramsciani, Cagliari, 23-27.04.l967). Roma: Editori Riuniti-Istituto Gramsci, l975, v. 1 e II. 


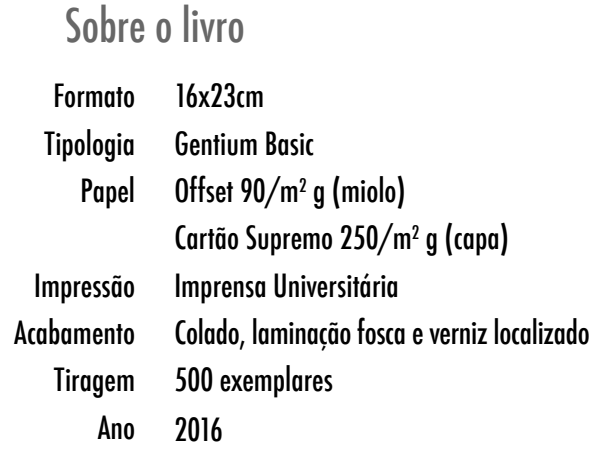

